DEPARTMENT OF THE INTERIOR

UNITED STATES GEOLOGICAL SURVEY

GEORGE OTIS SMITH, DIRECTOR

WATER-SuPply Paper 227

\title{
GEOLOGY AND UNDERGROUND WATERS OF SOUTH DAKOTA
}

BY

N. H. DARTON

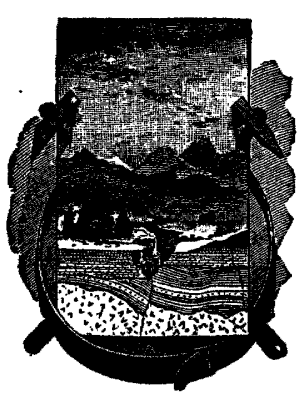

WASHINGTON

GOVERNMENT PRINTING OFFICE

1909 



\section{CONTENTS.}

Introduction

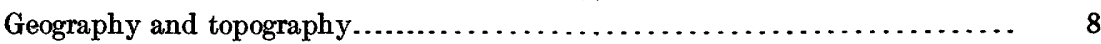

Geology of the Black Hills region.............................. 8

General relations........................................... 8

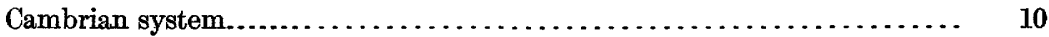

Deadwood sandstone...................................... 10

Ordovician system........................................ 11

Whitewood limestone.................................... 11

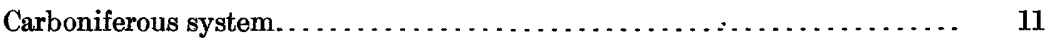

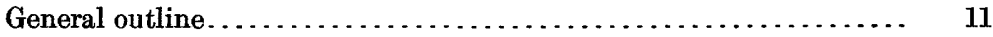

Englewood limestone.................................. 12

Pahasapa limestone.................................... 12

Minnelusa sandstone.................................... 13

Opeche formation........................................ 14

Minnekahta limestone................................ 14

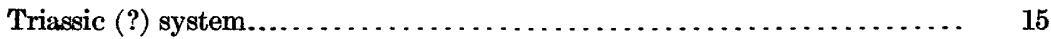

Spearfish formation......................................... 15

Jurassic system................................................ 16

Sundance formation.................................... 16

Unkpapa sandstone................................... $\quad 17$

Cretaceous system........................................ 17

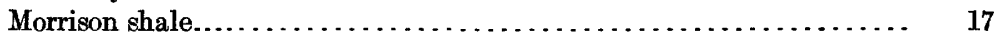

Lakota sandstone........................................ 18

Minnewaste limestone.................................. 18

Fuson formation....................................... 19

Dakota sandstone..................................... $\quad 20$

Benton group......................................... 20

Graneros shale................................. 20

Greenhorn limestone.................................. 21

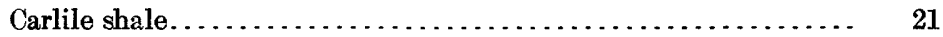

Niobrara formation................................... 22

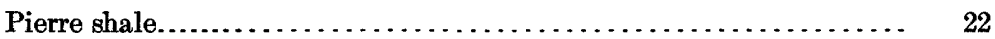

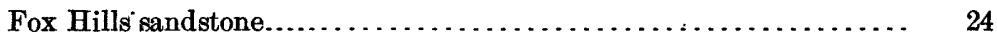

Tertiary system.............................................. 24

White River group.................................... 24

Geology of south-central South Dakota........................... $\quad 26$

General relations........................................... 26

Tertiary deposits................................................ 26

Geology of northwestern South Dakota......................... 27

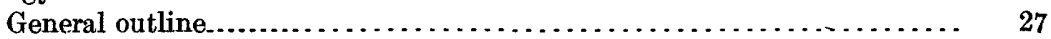

Fort Union, Laramie (?), and Fox Hills formations................ 28

Post-Eocene ................................................ 31

Geology of eastern South Dakota............................. 32

General structure........................................... 32

Archean and Algonkian rocks................................. 33

Paleozoic to Jurassic........................................ 40 
Geology of eastern South Dakota-Continued. Page.

Cretaceous system......................................... 41

Dakota sandstone...................................... 41

Benton group............................................ 48

Niobrara formation....................................... 53

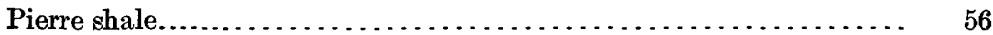

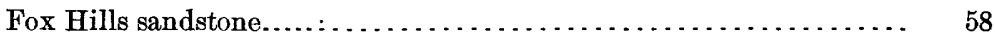

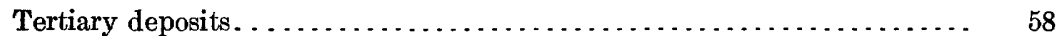

Quaternary deposits......................................... 58

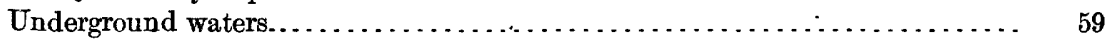

General conditions............................................... 59

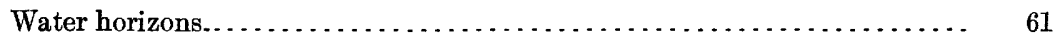

Dakota and associated sandstones........................... 61

Sandstones of the Benton group.......................... 62

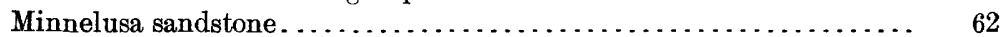

Fox Hills and overlying sandstones........................ 63

Deadwood sandstone..................................... 63

Chadron formation............................................ 63

Deep wells and well prospects in South Dakota.................. 64

Introductory statement. . . . . . . . . . . . . . .

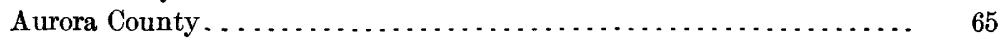

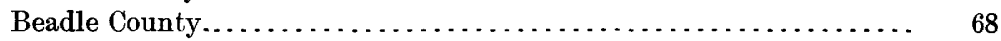

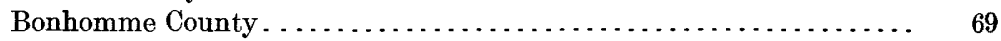

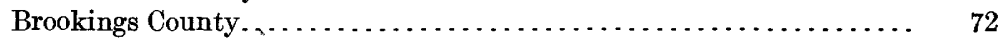

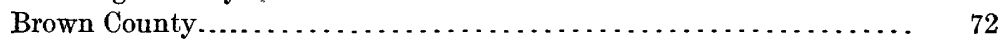

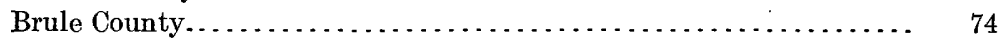

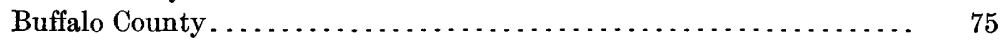

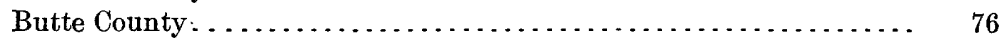

Belle Fourche and vicinity ........................... 78

United States Reclamation Service................... $\quad 79$

Orman well......................................... 80

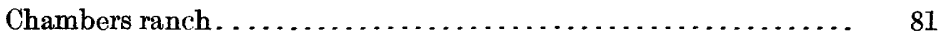

Vale .............................................. 81

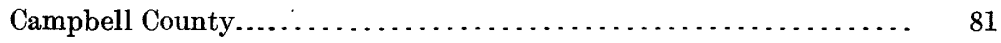

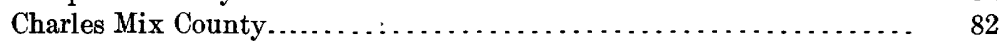

Cheyenne Indian Reservation. ....................... 84

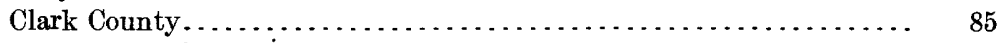

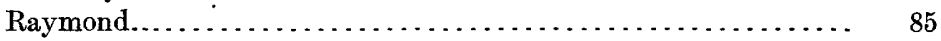

Clark ............................................ 86

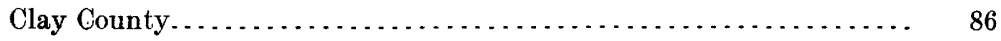

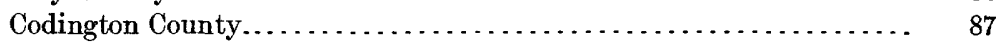

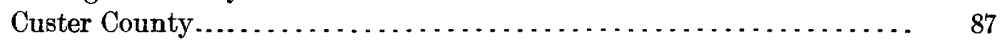

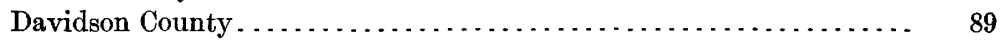

Day County............................................ 90

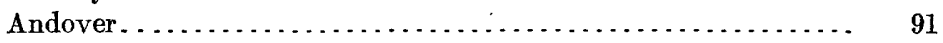

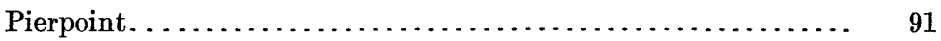

Webster............................................. 91

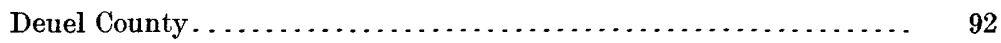

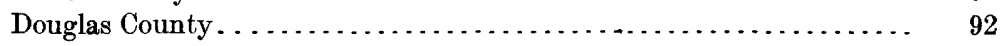

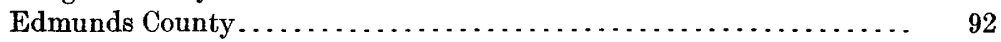

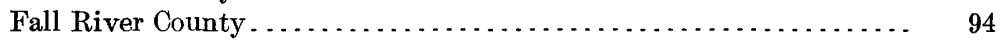

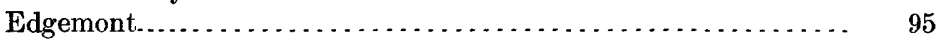

Minnekahta...................................... 99

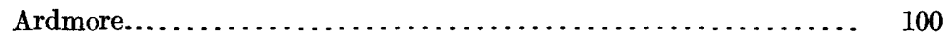


Underground waters-Continued.

Deep wells and well prospects in South Dakota-Continued.

Page.

Fall River County--Continued.

Argentine......................................... 100

Hot Springs......................................... 101

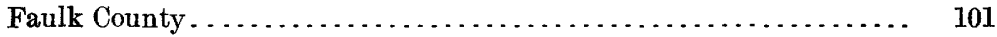

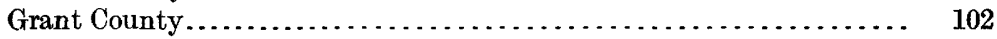

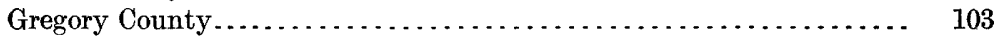

Hamlin County ...................................... 104

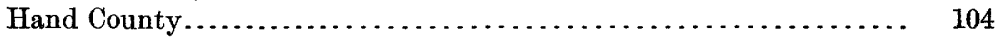

Hanson County ...................................... 106

Hughes County ............................................ 108

Hutchinson County ...................................... 109

Hyde County.......................................... 111

Jerauld County ..................................... 112

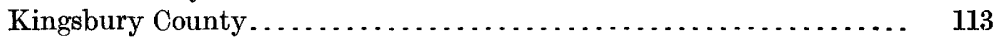

Lake County ....................................... 117

Lawrence County ..................................... 118

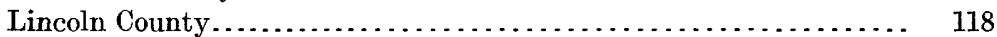

Lyman County......................................... 119

Wells opposite Chamberlain ......................... 119

McClure well.................................... $\quad 120$

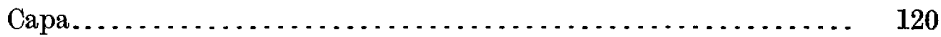

Kennebec.................................... 121

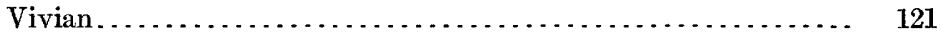

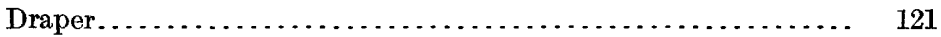

Murdo McKenzie.................................. 121

McCook County..................................... 122

McPherson County..................................... 122

Marshall County ..................................... 123

Meade County............................................ 124

Wells north of Sturgis................................ 124

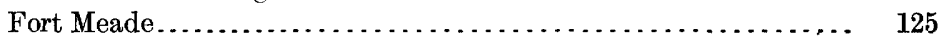

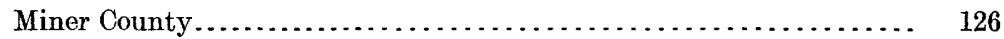

Minnehaha County......................................... 127

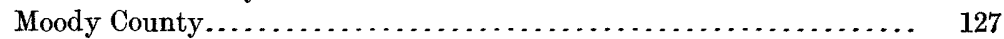

Pennington County ..................................... 128

Pine Ridge Indian Reservation.......................... 128

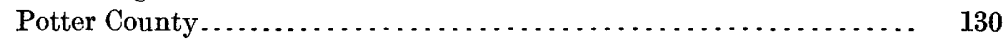

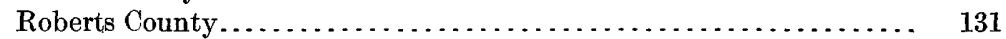

Rosebud Indian Reservation.............................. 131

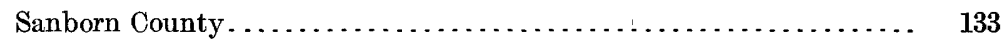

Spink County .............................................. 136

Standing Rock Indian Reservation......................... 138

Stanley County ............................................. 138

Wendte......................................... 139

Nowlin........................................ 139

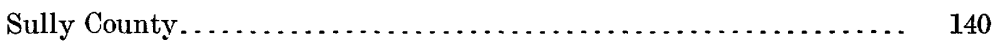

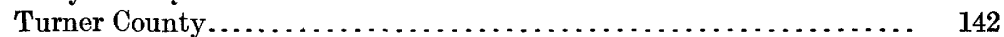

Union County ........................................ 142

Walworth County ....................................... 143

Yankton County........................................ 143

The construction and management of artesian wells................... 146

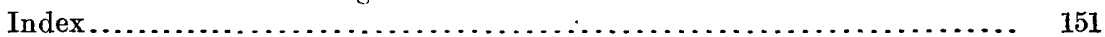




\section{ILLUSTRATIONS.}

Page.

Plate I. Geologic map of South Dakota........................ In pocket.

II. Columnar sections of Black Hills, etc..................... 8

III. $A$, Deadwood sandstone in northern part of Deadwood; $B$, Lakota sandstone lying unconformably on Unkpapa sandstone, Sheps

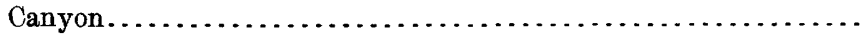

IV. $A$, Top sandstone of Minnelusa formation west of Sturgis; $B$, Minnekahta limestone west of Hermosa........................ 14

V. Greenhorn limestone southwest of Edgemont.................. 20

VI. Cross sections of South Dakota.......................... 24

VII. Chadron and Brule formations, Big Badlands............... 26

VIII. $A$, Central portion of Big Badlands, Cottonwood Draw; $B$, South end of Sheep Mountain, showing volcanic ash bed............ 28

IX. $A$, Upper member of White River group, Wounded Knee Creek; $B$, Lignite beds at south end of North Cave Hill............. 30

X. Map showing contour of bed-rock surface in eastern South Dakota... 32

XI. Map showing artesian conditions................... In pocket.

XII. Map of South Dakota, showing relative volumes of flows from wells.. $\quad 64$

XIII. Map showing structure of Dakota sandstone................. 66

XIV. Artesian well northwest of Mitchell....................... 90

XV. Artesian well at Woonsocket............................ 134

Figure 1. Columnar section of water horizons........................ 59

2. Apparatus illustrating declivity of head of liquids flowing from a reservoir......................................

3. Diagram of South Dakota, showing hydraulic gradient by contour lines of "head".................................. 61

4. Hydraulic gradient in eastern South Dakota................. 61

5. Section from Black Hills to Pine Ridge across Fall River County... 94

6. Map of Hanson County, showing artesian conditions............ 106

7. Diagram illustrating the escape of water from a lower into a higher horizon in a well................................. 148 


\title{
GEOLOGY AND UNDERGROUND WATERS OF SOUTH DAKOTA.
}

\author{
By N.. H. DaRTon,
}

\section{INTRODUCTION.}

This report is intended mainly to set forth the geologic conditions bearing on the occurrence of artesian waters in South Dakota. It comprises a description of the sedimentary rocks, a statement as to the results of all the deep borings which have been reported, and predictions as to the probable depths and area of flow of the deeperseated waters in all portions of the State. The water resources for shallow wells are not considered except in areas where such waters afford flows.

The investigation of underground waters is a branch of geology known as hydrology. In order to ascertain the underground conditions, it is necessary to map the surface distribution of the geologic formations, to measure their thickness, and to determine their structure. The character of the various sediments has to be examined to ascertain their porosity, and in many places their chemical nature has to be investigated in its bearing on the composition of the contained water. The evidence of fossils must be utilized to aid in establishing the identity of the various formations from place to place. Accordingly a hydrologic investigation of any area requires a detailed geologic survey, especially of its sedimentary rocks.

Underground water is derived from rain and melted snow and passes underground in porous materials such as sandstone, sand, and gravel. Some of it is absorbed directly by such materials, but much water passes underground by the sinking of streams in crossing the upturned edges of sandstones and other porous rocks. Along the slopes of the Black Hills many of the streams lose a large portion of their volume in crossing the porous strata. Much of the water thus absorbed seeps slowly through the rocks as their dip carries them to lower levels. The water is kept underground by a thick mass of relatively impervious shale overlying the sandstones, and when the sandstones are penetrated by wells in the lower lands artesian flows are obtained. 


\section{GEOGRAPHY AND TOPOGRAPHY.}

South Dakota lies entirely within the Great Plains province, which comprises that part of the continental slope extending from the foot of the Rocky Mountains eastward to the valley of the Mississippi and merging into the prairies on the north and the low plains adjoining the Gulf coast and the Mississippi embayment on the south. The plains present wide areas of tabular surfaces, traversed by the broad, shallow valleys of large rivers and more or less deeply cut by the narrower valleys of the lateral drainage. Smooth surfaces and eastward-sloping rolling plains are the characteristic features, but in portions of the province the landscape is diversified by buttes, extended escarpments, and local areas of badlands.

The Great Plains province as a whole descends to the east about 10 feet in each mile, its altitude ranging from about 6,000 feet at the base of the Rocky Mountains to about 1,000 feet near Mississippi River. The altitudes and rates of slope vary considerably in different districts, particularly along the middle course of Missouri River, where the general level has been greatly reduced. South Dakota presents great extremes of altitude and variety of topography. Its lowest point, Bigstone Lake, is less than a thousand (967) feet above the sea, while the altitude of Harney Peak is 7,240 feet.

The principal drainage of South Dakota is carried by the Missouri and its tributaries. The main stream crosses near the middle of the State in a general southeasterly direction, receiving from the west the waters of Grand, Owl, Cheyenne, and White rivers, and from the east numerous smaller streams. At Yankton it is joined by James River, which also crosses the State from north to south, and in the southeast corner the Big Sioux enters it. The drainage of the northeast corner of the State is carried into the Mississippi by Minnesota River.

\section{GEOLOGY OF THE BLACK HILLS REGION.a}

\section{GENERAL RELATIONS.}

The Black Hills uplift is an irregular, dome-shaped anticline, embracing an oval area 125 miles long and 60 miles wide, with its longer dimension lying nearly northwest and southeast. It is situated in a wide area of nearly horizontal beds and has brought above the general level of the plains an area of pre-Cambrian crystalline rocks about

a For a detailed account of the geology of the Black Hills, see Darton, N. H., Geology and underground water resources of the central Great Plains: Prof. Paper U. S. Geol. Survey No. 32, 1905, 433 pp.; Darton, N. H., Preliminary description of the geology and water resources of the southern half of the Black Hills and adjoining regions in South Dakota and Wyoming: Twenty-first Ann. Rept. U. S. Geol. Survey, pt. 4, 1901, pp. 489-599; Jaggar, T. A., jr., Laccoliths of the Black Hills: Twenty-first Ann. Rept. U. S. Geol. Survey, pt. 3, 1901, pp. 163-303; Darton, N. H., and others, Oelrichs (No. 85), Newcastle (No. 107), Edgemont (No. 108), Sundance (No. 127), Aladdin (No. 128), Devils Tower (No. 150), and Belle Fourche (No. 165) folios: Geologic Atlas U. S., U. S. Geol. Survey, 1902-1909. 


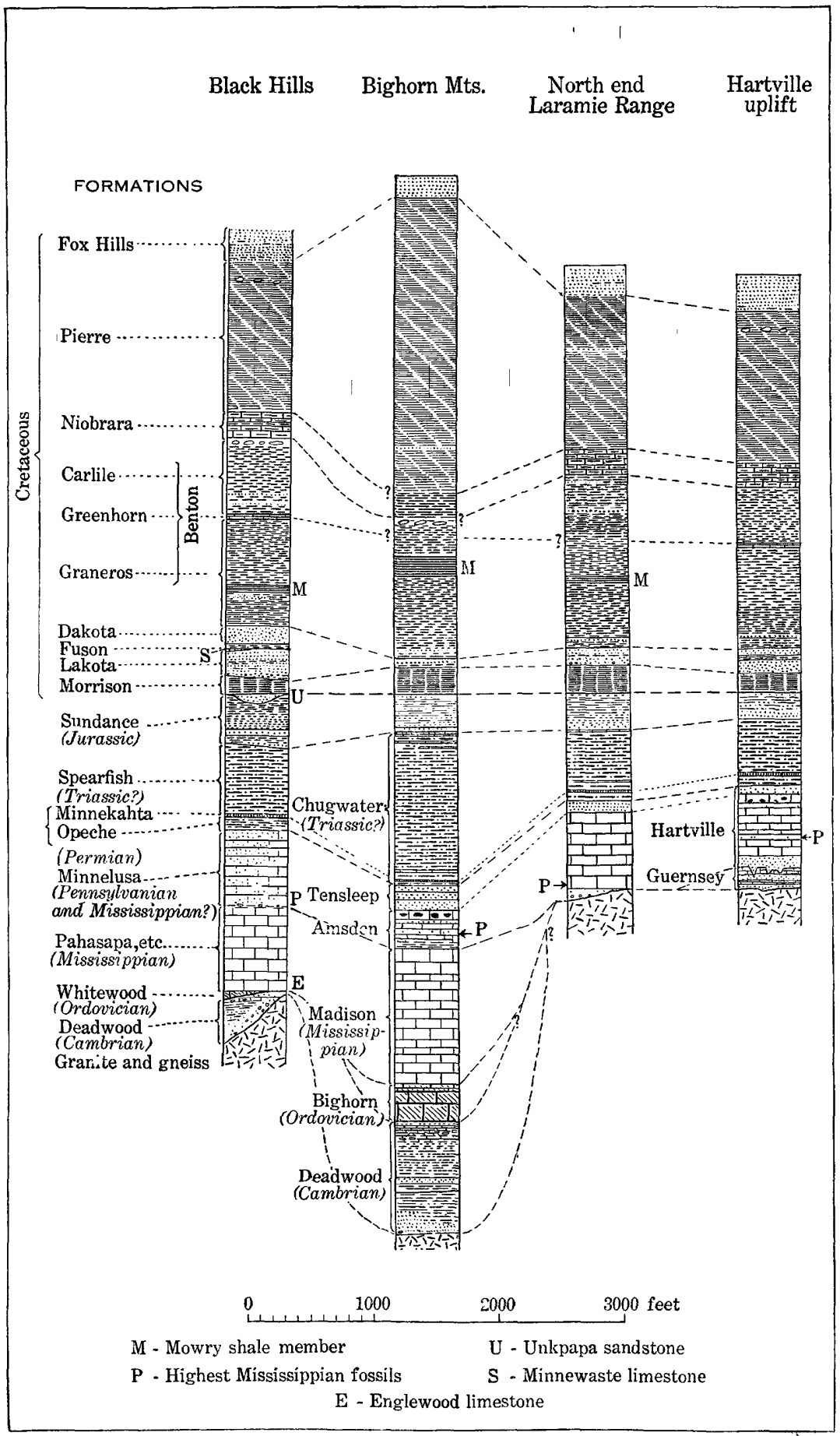

COLUMNAR SECTIONS OF BLACK HILLS, BIGHORN MOUNTAINS, NORTH END OF LARAMIE RANGE, AND HARTVILLE UPLIFT. 

which there is upturned a nearly complete sequence of sedimentary formations, ranging in age from middle Cambrian to late Cretaceous, all dipping away from the central nucleus. There are also extensive overlaps of the Tertiary deposits which underlie much of the adjoining plains area. The region affords rare opportunity for the study of stratigraphic relations and variations. Many of the rocks are hard, and the streams flowing out of the central mountain area have cut canyons and gorges, in the walls of which the formations are extensively exhibited. The structure along the sides of the uplift is that of a monocline dipping toward the plains. The oldest sedimentary rocks constitute an escarpment facing the crystalline-rock area, and each stratum passes beneath a younger one in regular succession outward toward the margin of the uplift. Sections 2 and 3, Plate VI, show the general relations of the formations. The sedimentary members consist of a series of thick sheets of sandstone, limestone, and shale, all of which are essentially conformable in position, except the overlapping areas of the Tertiary deposits, which extend across the edges of the older formations. The stratigraphy presents many features of similarity to the succession of rocks in the Rocky Mountains of Colorado and of Wyoming, but it possesses numerous distinctive local features. The principal stratigraphic components are shown in the first column in Plate II; other columns on the same plate show their equivalency in other regions. The Silurian and Devonian and parts of the Cambrian, Ordovician, Triassic, Jurassic, and Tertiary are absent.

The following is a list of the formations which are exhibited in the uplift, with a generalized statement as to the ordinary thickness, characteristics, and age:

Generalized geologic section in the Black Hills region in South Dakota.

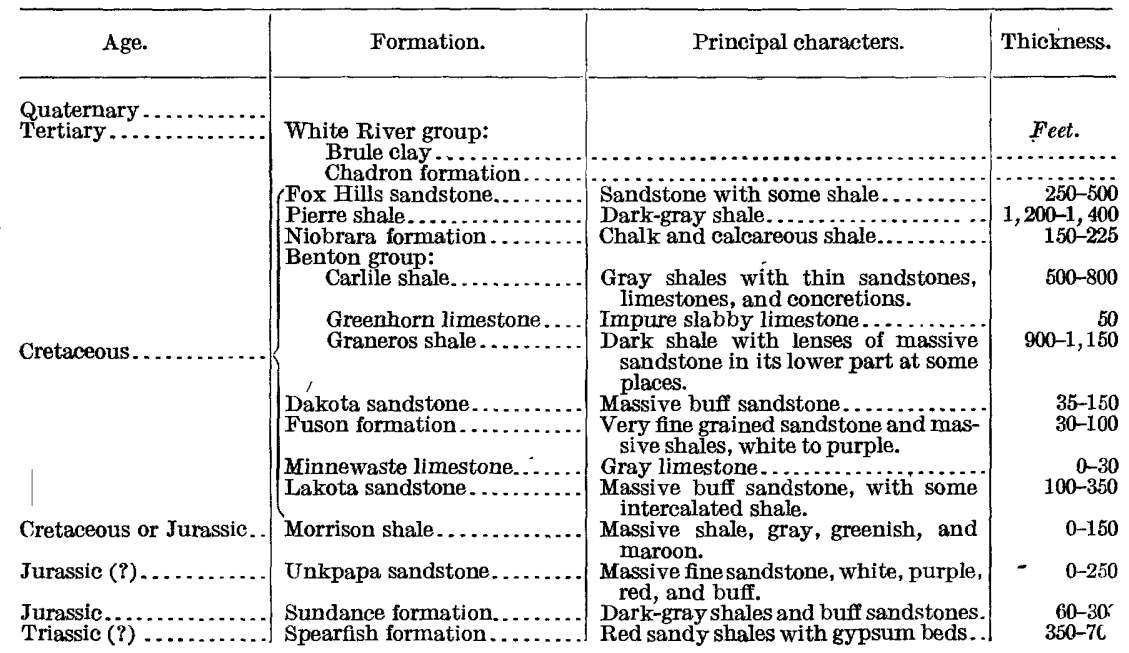


Generalized geologic section in the Black Hills region in South Dakota-Continued.

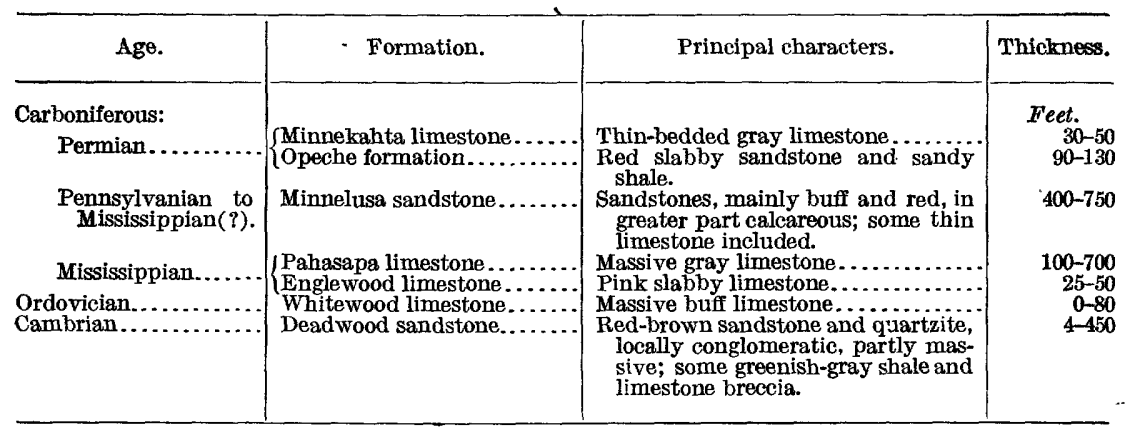

CAMBRIAN SYSTEM.

DEADWOOD SANDSTONE.

The representative of the Cambrian, known as the Deadwood sandstone, appears to encircle the Black Hills entirely, but has been removed completely from the central area. Probably it did not originally cover the entire area of crystalline rocks in this region, a portion of these old rocks forming the surface during the greater part of Cambrian time and furnishing the material for the earlier sediments. The Deadwood strata lie unconformably across the upturned edges of the schists and granites, on a relatively smooth surface, with local shallow channels. The formation is thick in the northern hills, attaining a thickness of more than 400 feet in the Deadwood region (see Pl. III, $A$ ), but thins gradually to the south and especially to the southeast. In the region west of Fairburn exposures were found in which the formation is represented by only 4 feet of coarse sandstone lying upon pre-Cambrian schists. On Rapid Creek its thickness averages about 200 feet.

The materials of the formation are always predominantly sandy and the colors dark reddish brown or dirty buff. The basal member is ordinarily a hard, massive reddish-brown quartzite, with pebbly streaks. As the formation thickens this member can be seen to be overlain by thinner-bedded, softer sandstones, in some places interbedded with more or less shale. Portions of the basal beds of the Deadwood are conglomeratic, ranging from those with a sprinkling of quartz pebbles in the sandstone to a very coarse, heavy conglomerate made up of large rounded masses of crystalline rocks and vein quartz in a red-brown matrix.

Outcrops of the Deadwood sandstone vary greatly in prominence, but their extent in general is small. For many miles they lie in the slope below the high escarpments of the Pahasapa limestone, where the ledges are in places deeply buried under talus from the cliffs above. This is particularly the case on the west side of the uplift. 


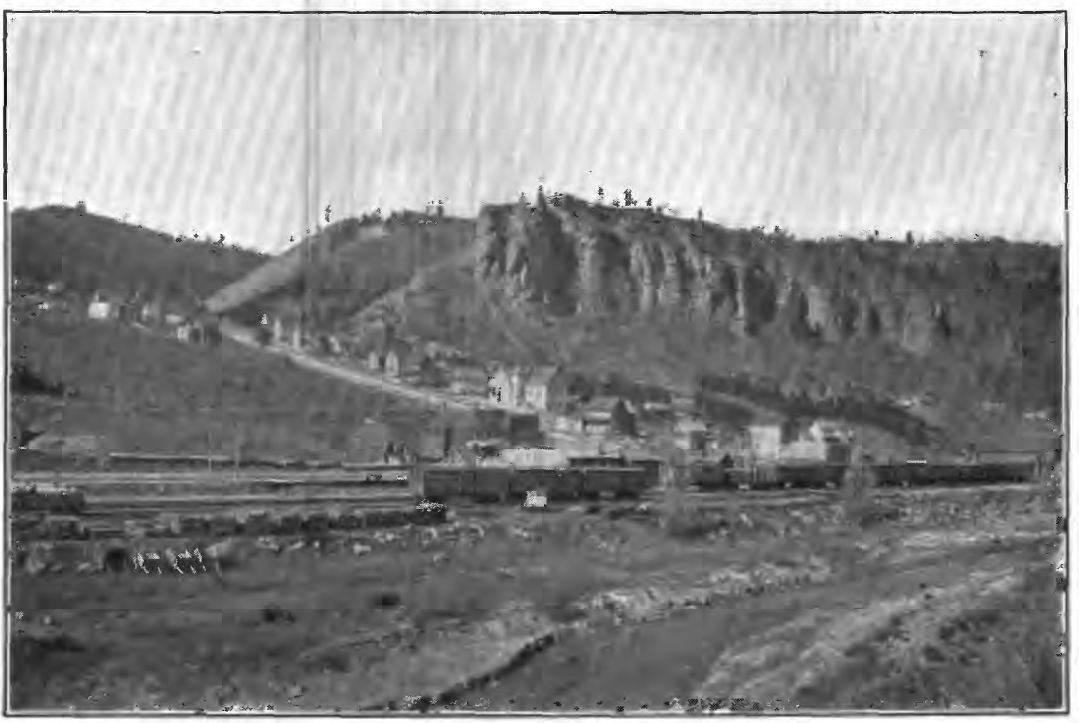

A. DEADWOOD SANDSTONE IN NORTHERN PART OF DEADWOOD, S. DAK. Looking northwest.

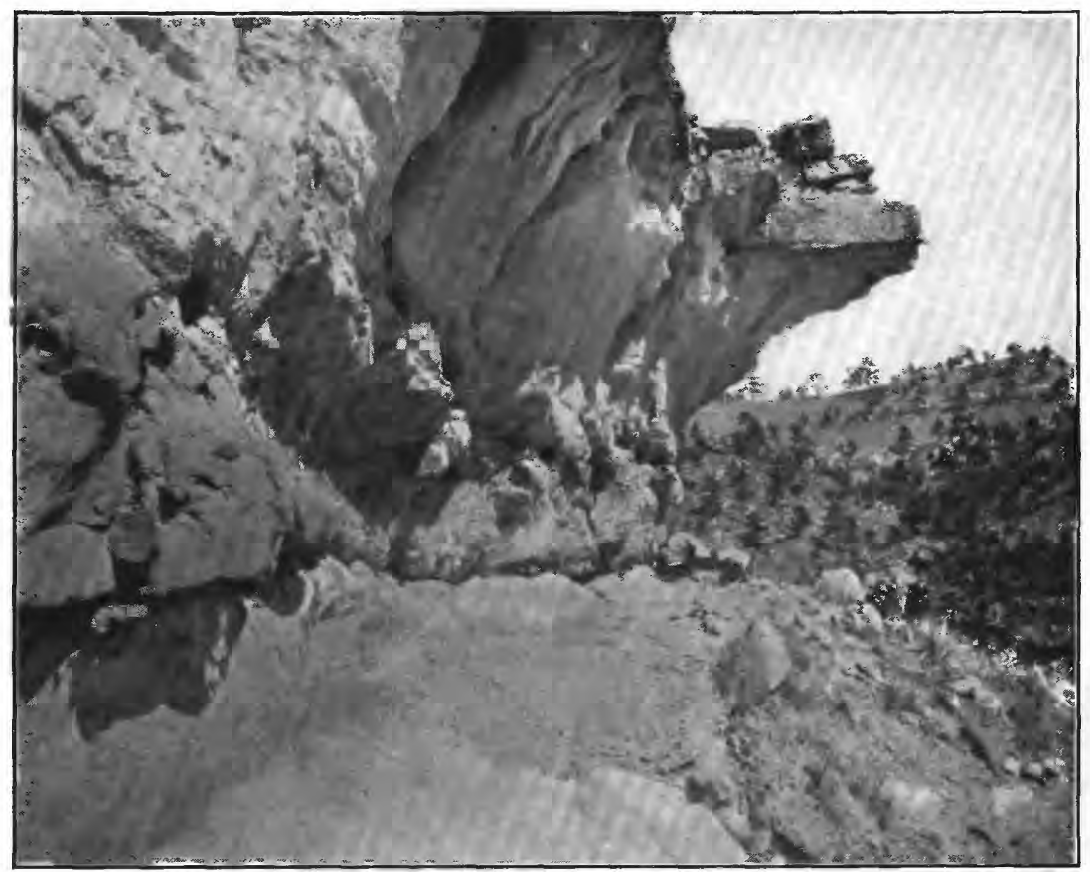

B. LAKOTA SANDSTONE LYING UNCONFORMABLY ON UNKPAPA SANDSTONE, NORTH SIDE OF SHEPS CANYON, SOUTH DAKOTA. 
On the east side, where the dip is steeper, the hard quartzitic basal member gives rise to knobs or long bare rocky slopes of considerable prominence. The many canyons cutting back into the western escarpment and those crossing the ridges on the east side of the uplift afford numerous excellent exposures.

In the region about Deadwood the formation comprises from 1 to 30 feet of basal conglomerate, overlain by 30 feet of sandstone, followed by 200 to 400 feet of gray shales, with layers of flaggy limestone, limestone conglomerate, and sandstone. Near the top is a very characteristic member of hard massive sandstone 5 to 22 feet thick, overlain by 20 to 45 feet of green shales. The limestone conglomerate consists of flat pebbles and flakes of limestone more or less thickly sprinkled with glauconite grains, a characteristic feature of the Cambrian of the Northwest. The formation contains middle Cambrian fossils.

\section{ORDOVICIAN SYSTEM.}

WHITEWOOD LIMESTONE.

The Whitewood limestone is conspicuous in the northern Black Hills, particularly about Deadwood, where it has a thickness of 80 feet and outcrops extensively in a number of canyons, a typical exposure appearing in Whitewood Canyon below Deadwood. It thins - to the southeast and southwest and finally disappears. The rock is a massive tough limestone, of buff color with brownish spots or mottlings. It contains characteristic Ordovician fossils. In part of the area it is overlain by several feet of greenish shales which may possibly be Devonian, though no fossils have yet been found in them.

\section{CARBONIFEROUS SYSTEM.}

GENERAL OUTLINE.

In the Black Hills region the Carboniferous rocks comprise several formations apparently representing continuous deposition throughout the period. Many of the formations which compose the Carboniferous in the central United States are not recognized in the Black Hills, unless possibly in their broader faunal relations. There appear to be five separable formations-the thin Englewood limestone at the base, the massive gray Pahasapa limestone next above, the thick mass of Minnelusa sandy beds, the Opeche red beds, and the Minnekahta limestone; the last, at least, of Permian age. The Carboniferous lies directly on the Cambrian in the central and southern parts of the Black Hills, but to the north it is separated from the Cambrian by the Whitewood limestone and overlying green shales described above. 
ENGLEWOOD LIMESTONE.

The Englewood formation consists of a series of thin-bedded pale pinkish-buff limestones, which appear to extend continuously around the Black Hills, everywhere immediately underlying the Pahasapa limestone. It averages 25 to 50 feet in thickness and presents numerous outcrops in the lower slopes of the limestone escarpment and in canyons. It merges rapidly into the overlying limestone, here and there with a few feet of impure buff limestone intervening. Generally it is sharply separated from the Deadwood sandstone or the Whitewood limestone, but only by an abrupt change in the nature of the materials. It is usually fossiliferous, containing numerous corals and a few shells, by which it is probably to be correlated with the Chouteau limestone of the Mississippi Valley.

PAHASAPA LIMESTONE.

The prominent Pahasapa limestone, formerly known as the "gray limestone," has an extensive outcrop area in the Black Hills uplift, constituting much of the high, wide plateau west of the central region of crystalline rocks, and being characteristically exhibited in the great lines of cliffs in the escarpment surrounding that region. It consists of a thick deposit of massive gray limestone, usually outcropping either in precipitous cliffs with many picturesque irregularities of form or in wide, flat surfaces. The formation does not present any noteworthy lithologic subdivisions, but in many places its upper part is siliceous and flinty and stained red to a greater or. less extent from the overlying basal red shale of the Minnelusa.

The most extensive exposures of the Pahasapa limestone are in the great plateau west of Custer. Here the formation begins in a line of high cliffs, surmounting slopes consisting of crystalline schists and of the relatively thin sheets of Englewood limestone and Deadwood sandstone. In Pennington County the plateau has a width of 10 miles of continuous limestone outcrop, constituting the most elevated area in the Black Hills, except the small summit of Harney Peak. To the west the limestone passes beneath the Minnelusa sandstone, but it is exposed again in the arch of the steep anticline near the Wyoming-South Dakota line. East of the crystalline-rock area the limestone stands out on many conspicuous knobs or lies on the eastern slopes of ridges due to the quartzite of the Deadwood formation but does not attain the high altitude which it has farther west. The steeper dip to the east soon carries the formation below the surface in that direction, but it constitutes the walls of many of the canyons from Beaver Creek northward, notably the deep canyon of Spearfish Creek. 
The thickness of the Pahasapa limestone in the central and southern Black Hills ranges from about 450 feet at the northwest to 225 feet at the east and southeast. All along the southeast side of the hills it remains at 225 feet, with slight local variations; then increases to 300 feet near Rapid, 350 feet on Elk Creek, and from 400 to 500 feet in the Deadwood region. In Spearfish Canyon 700 feet is reported by Jaggar. Fossils indicating Mississippian (lower Carboniferous) age occur sparingly throughout the formation.

MINNELUSA SANDSTONE.

The Mirnelusa sandstone is next to the Pahasapa limestone in order of prominence among the Black Hills formations, extending around the uplift in a broad zone of conspicuous outcrops. The formation varies somewhat in components, but consists mainly of thick masses of buff and reddish sandstones, which are striking features in the walls of the many canyons by which the formation is traversed. The sandstones are mostly fine grained, massively bedded, and in their unweathered condition contain a considerable proportion of carbonate of lime. Thin sheets of limestone occur in places and, less commonly, sandy shales of red or gray color. Some layers are cherty. Although the formation probably was deposited at the same time as the "Coal Measures," which contain extensive beds of coal in the Mississippi Valley, it is barren of coal in the Black Hills, except in the local occurrence of very thin layers of impure coal in gray shales. The formation is thickest on the west side, where it is fully 600 feet thick. It thins gradually to the south and east, being about 420 feet thick west of Hot Springs and less than 400 feet thick on Spring Creek.

Although the Minnelusa sandstone has wide areas of exposure, it does not give rise to very marked topographic features, generally occupying elevated slopes surmounted by low hills and ridges due to its harder layers. Its inner boundary is usually not marked by an escarpment such as is seen at the inner margin of the Pahasapa limestone, and there is no noticeable topographic break in passing from one formation to the other. On slopes of the two formations the soil becomes sandy on the Minnelusa beds. In the many canyons which are cut through the formation the Pahasapa limestone is usually exposed beneath it without presenting any change of features except in color. The lower members of the Minnelusa are generally buff slabby sandstones, in many places having a thickness of 100 feet and a thin persistent bed of red shale.

Breccias, which occur in the middle beds, are a distinctive feature throughout the southern Black Hills. The brecciated material is usually somewhat more calcareous than the matrix, but it is all of 
local origin. In the region west of Hermosa and thence northward the Minnelusa consists of a thick mass of coffee-colored sandstone at the top (see PI. IV,$A$ ), reddish-buff sandstone with some thin interbedded limestone layers next below, and a basal member of gray sandstone.

The age of the formation has not been satisfactorily ascertained, for fossils are rare. A few impressions found in the upper beds west of Hot Springs appeared to be forms which indicate Pennsylvanian (upper Carboniferous) age for these beds. Mississippian (lower Carboniferous) forms have been found in concretions in the red shale at the base of the formation.

\section{OPECHE FORMATION.}

The series of red beds lying between the Minnelusa sandstone and the Minnekahta limestone extends continuously around the Black Hills. It is called the Opeche formation. Its exposures are almost invariably confined to the slopes below the escarpments of Minnekahta limestone. In thickness it averages slightly less than 100 feet. The materials are soft red sandstone, mainly thin bedded and containing variable amounts of clay admixture. At the top of the formation, for the first few feet below the Minnekahta limestone, there are shales which are invariably of deep-purple color. The basal beds of the formation are usually red sandstones, the beds varying in thickness from 4 to 15 inches.

On Spring, Battle, and French creeks the formation averages about 100 feet in thickness; in Beaver Canyon it attains its maximum thickness of 150 feet; on Cold Brook, 4 miles northwest of Hot Springs, it is $\mathbf{1 1 5}$ feet thick, with purple clay at the top, 50 feet of red sandy clay below, and 60 feet of red sandstone at the bottom, in beds 1 to 4 feet thick with red-clay partings; farther down Cold Brook, at a point $1 \frac{1}{2}$ miles from Hot Springs, a thickness of 135 feet is exhibited. Along the southwest side of the Black Hills the thickness averages from 90 to 100 feet, and on the northern slopes it is about 75 feet.

The age of the formation has not been definitely determined, for so far it has yielded no fossils. From the facts that the overlying Minnekahta limestone is of Permian age and that the deposition of red beds in some other regions began in Permian time, the formation is provisionally assigned to that series.

\section{MINNEKAHTA LIMESTONE.}

The Minnekahta limestone, long known as the "Purple limestone," is a prominent formation in the Black Hills region. Though thin, averaging less than 50 feet in thickness, it is hard and covers moderately extensive areas on the outer slopes of the Minnelusa sandstone. 


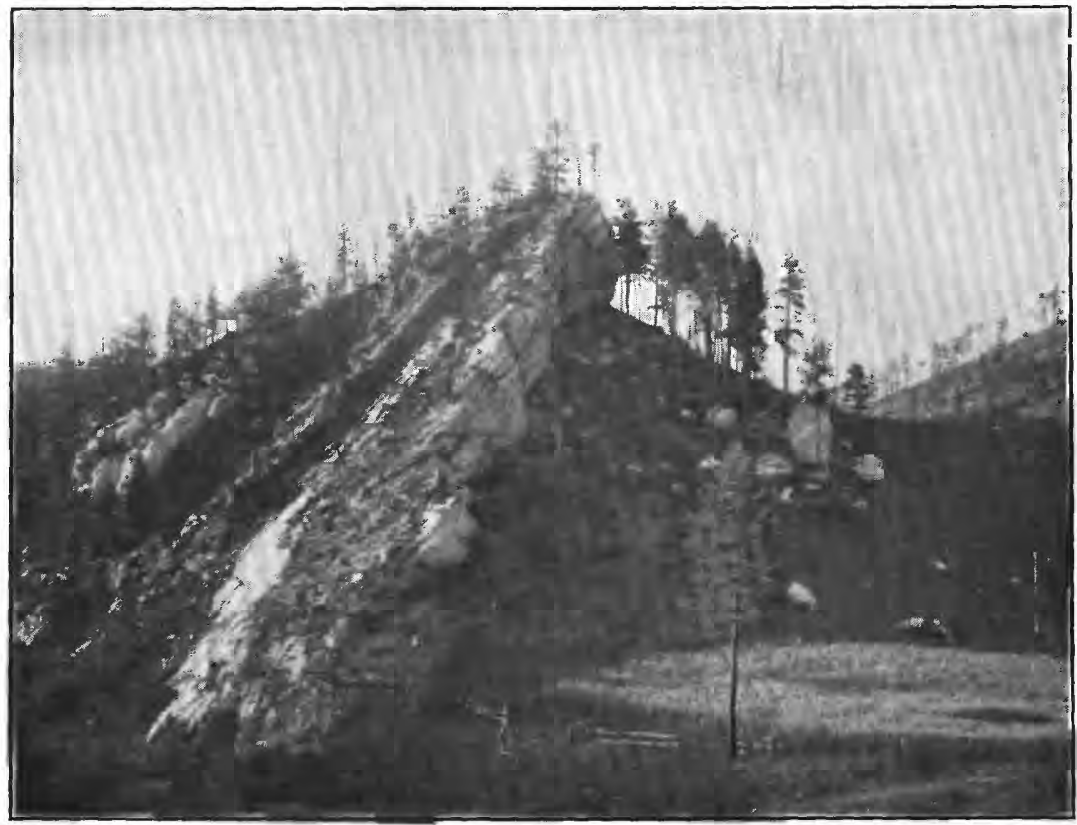

A. TOP SANDSTONE OF MiNNELUSA FORMATION, BEAR BUTTE CANYON, WEST OF STURGIS, S. DAK.

An important water-bearing horizon. (Photograph by T. A. Jaggar, jr.)

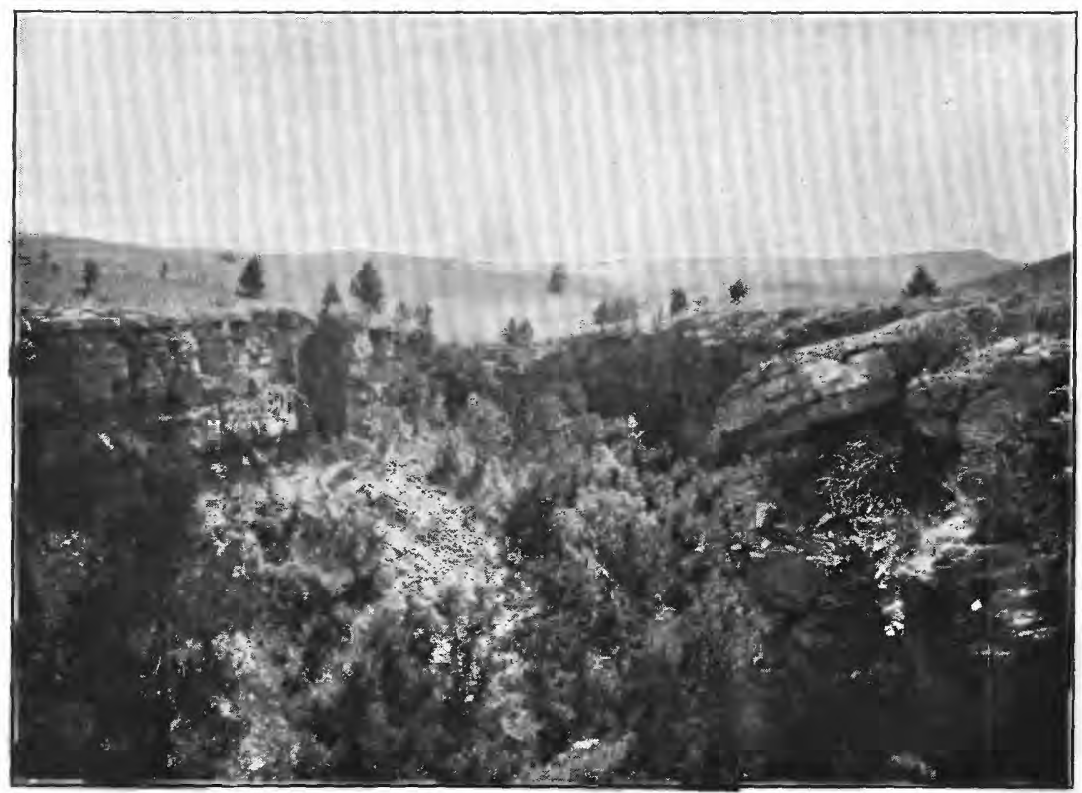

B. MINNEKAHTA LIMESTONE, WILDCAT GULCH, WEST OF HERMOSA, S. DAK. 
The prominence of the Minnekahta limestone outerops is due largely to the fact that the overlying formation is soft red shale, which has been deeply eroded, leaving the underlying limestone bare on slopes up which the red shale originally extended. As the underlying Opeche formation is also soft, the limestone nearly everywhere Presents an escarpment, and the many canyons which are cut through it have vertical limestone walls. (See Pl. IV, B.)

The formation is uniform in character throughout, being a thinbedded light-colored limestone containing magnesia and more or less clay. Its bedding is - a characteristic feature, although the thin layers are so cemented together that the outcropping ledges present a massive appearance. On weathering, however, it breaks into slabs usually 2 to 3 inches thick. The general appearance of the formation is slightly pinkish, with a tinge of purple, from which the term "Purple limestone" originated. The Minnekahta limestone contains some fossils which are believed to be Permian, in the sense in which that term is used in the Mississippi Valley.

\section{TRIASSIC (?) SYSTEM.}

\section{SPEARFISH FORMATION.}

The Spearfish formation is the conspicuous series of gypsiferous red beds encircling the Black Hills and in most places giving rise to the wide Red Valley. This valley is treeless and usually presents wide areas of bare red slopes and red buttes, with numerous outcrops of gypsum.

The formation consists of 350 to 695 feet of red sandy shale, with intercalated beds of gypsum in places 30 feet thick. The bright red of the shale and the snowy whiteness of the gypsum are. striking features. Were it not for the beds of gypsum the formation would present no noticeable features of stratigraphy. The sedimentary material is almost entirely a red shale containing varying amounts of sand admixture, and is generally thin bedded. The gypsum occurs in beds at various horizons, some of the larger beds extending continuously over wide areas. There is also throughout the formation more or less gypsum of secondary deposition in very small veins.

The continuity of the outcrops of the red beds is considerably broken in the region west of Fairburn and Hermosa by overlaps of the Tertiary formations, which in some places completely fill the Red Valley. The width of the outcrop is from 1 to 3 miles, attaining its maximum in the region west of Buffalo Gap and in the broad belt extending from a point east of Minnekahta station nearly to the north end of Elk Mountain. Owing to the local steep dip of the formation, the outcrop is very narrow for 5 miles north from Cascade Springs. 
The thickness of the Spearfish formation can seldom be determined with any degree of accuracy, owing to the softness of its materials and the numerous variations in its dip. In the deep well at Fort Meade the formation is 695 feet thick. Along the east side of the Black Hills it appears to be between 350 and 400 feet thick, so far as can be estimated from very indefinite dip observations. In this region the principal bed of gypsum occurs considerably below the center of the formation. West of Hermosa this gypsum bed has a thickness of about 15 feet, but toward the south, in the region west of Fairburn, it thins out and may at some points be absent. West of Buffalo Gap the gypsum deposits increase in thickness and attain their maximum prominence at Hot Springs, where the principal beds have a thickness of $33 \frac{1}{2}$ feet, with a 10 -foot parting of red shale between them. In the wide part of Red Valley, extending southward from Hot Springs to Sheps Canyon, gypsum beds are a conspicuous feature, but they gradually diminish in thickness in that direction.

At Cascade Springs and thence northward on the west side of the anticline the dips are very steep and the outcrop of the Spearfish formation becomes so narrow that the Red Valley is only a few rods in width from the springs northward nearly to the railroad. Here a relatively accurate measurement was made of the beds from the steep slopes of the Minnekahta limestone to the basal sandstone beds of the Sundance formation. At the base of the Spearfish formation there are 150 feet of red sandy shales, then a bed of gypsum, in places 20 feet in thickness, overlain by 250 feet of red sandy shales with a few thin layers of gypsum, the formation here having a total thickness of 420 feet. Near Spearfish and Sturgis thick beds of gypsum occur near the top of the formation and a thinner bed is included about 120 feet above the base.

Throughout the Black Hills the formation is distinctly separated from the underlying Minnekahta limestone and the overlying shales or red sandstone of the Sundance formation. It has been regarded as Triassic in age, because it lies unconformably beneath marine Jurassic deposits and is underlain by the Minnekahta limestone, which is thought to be of Permian age. No determinable fossils have yet been discovered in the formation.

JURASSIC SYSTEM.

SUNDANCE FORMATION.

The outcrop of the Sundance formation extends continuously around the Black Hills uplift, appearing mainly along the outer slope of the Red Valley, or the lower, inner slopes of the hogback range. It carries abundant marine fossils throughout. The formation comprises from 225 to 350 feet of shales and sandstones, in a series which 
varies but little in sequence in different portions of the region. The succession includes 50 to 60 feet of lower dark shale, 30 feet of massive buff ripple-marked sandstone, 30 feet of reddish sandy shale, and at the top 100 to 200 feet of green shale with thin fossiliferous limestone layers. Some local variation is presented, especially in the occurrence of massive red or buff basal sandstone which in many places attains a thickness of 25 feet. The fossils are of later Jurassic age.

\section{UNKPAPA SANDSTONE.}

The Unkpapa sandstone, the next overlying formation, is everywhere clearly separable both from the Sundance formation below and the Morrison shale or the Lakota sandstone above. It is a very massive fine-grained sandstone, varying in color from white to purple and buff. Its greatest development is in the foothill ridges or hogback east of Hot Springs. Its first outcrops to the south are observed about Cascade Springs, and it extends continuously from that region past Hot Springs, all along the east side of the Black Hills to Belle Fourche River. North of Buffalo Gap its thickness diminishes to less than 50 feet in most places, but north of Rapid it increases locally to 150 feet. It is thickest in Sheps Canyon, southeast of Hot Springs, where 225 feet was measured.

Some of the exposures east of Hot -Springs are very striking in their colorings of brilliant pink, purple, and pure white. Near Buffalo Gap the rock has been quarried to some extent for building stone. Portions of the rock are beautifully banded with various colors, in part along the stratification planes, but in places diagonal to them. In the quarry west of Buffalo Gap these banded beds exhibit minute faulting in a most instructive manner, affording fine illustrations of block-fault phenomena. Contacts with the overlying buff Lakota sandstone are exposed at many points, and are marked by considerable unconformity due to erosion. One of them is shown in Plate III, $B$.

\section{CRETACEOUS SYSTEM.}

\section{MORRISON SHALE.}

The Morrison shale outcrop extends along the upper, inner slopes of the hogback range. It is absent in the southeastern portion of the uplift, from the vicinity of Hermosa to a point southwest of Hot Springs. Elsewhere the formation is generally from 100 to 150 feet thick and lies between the Unkpapa sandstone and the Lakota sandstone. The formation is mainly composed of "joint clay" or massive shale, somewhat darker and more fissile to the east than to the north and west. The predominating color is a very pale greenish gray, merging into chocolate and maroon. Thin beds of fine-grained 
white or light-gray sandstone and some thin local layers of impure limestone are included. A few fresh-water shells were observed, and there is an almost general occurrence of dinosaur bones. The latter are classed in the Jurassic by some paleontologists, but others regard them as early Cretaceous.

\section{LAKOTA SANDSTONE.}

The Lakota formation, which consists mainly of sandstone, gives rise to the crest and upper slopes of the hogback ranges that form the outer encircling rim of the Black Hills. Its sandstones are hard, coarse-grained, cross-bedded, and massive, with partings of shale of no great thickness. Local deposits of coal occur in its base about Cambria, on Hay Creek, and east of Edgemont. In the central and southern Black Hills the thickness is usually from 200 to 300 feet, with local variations; to the north it averages about 100 feet. The Lakota lies on the Morrison shale except in the region from Hermosa to a point beyond Hot Springs, where it overlaps unconformably onto the Unkpapa sandstone. A typical exposure of this unconformity is represented in Plate III, $B$.

Although the Lakota sandstone presents the predominant features above described, there are numerous local variations in the thickness of the beds and in the occurrence of intercalated fine-grained members. In the canyon of Fall River, where the formation has a thickness varying from 225 to 250 feet, the beds of sandstone are very massive and are separated by greenish-gray shales 15 to 20 feet thick at several horizons. The uppermost member, a dull-yellow sandstone, is immediately overlain by the Minnewaste limestone in the region east of Hot Springs. The lower beds are conglomeratic at most localities.

Except petrified wood, which is abundant, fossils are rarely found in the Lakota sandstone. A few bones of a stegosaur were obtained near Buffalo Gap and remains of isopods, Estheria, fish, and crocodile were found 3 miles north of Piedmont. Plants of Lower Cretaceous age occur east of Hot Springs and in the Hay Creek region, and pine needles are abundant in some of the coaly layers. Cycads are found in places, notably in the slopes southwest of Minnekahta and near Blackhawk.

\section{MINNEWASTE LIMESTONE.}

The Minnewaste limestone overlies the Lakota sandstone from the vicinity of Cascade Springs northward to Buffalo Gap. For the greater part of its course it has a thickness of only 25 feet, but is conspicuous on the hogback ranges east of Hot Springs, extending far up the slopes on some of the higher divides. One of the most extensive exposures is at the falls of Cheyenne River, which are due 
to this formation, the water falling over a ledge of it about 20 feet high. Widespread outcrops may be seen in the anticline 2 miles east of Hot Springs, where the strata dip steeply to the west. It thins out rapidly north of Buffalo Gap and appears to be entirely absent in the canyon of Fuson Creek. It is thin at Cascade Springs, and disappears a short distance to the west. An extended search has failed to detect any fossils in it, but it is of Lower Cretaceous age, as it lies below the Fuson formation. The rock is a nearly pure, lightgray limestone, presenting uniform character throughout.

FUSON FORMATION.

The Fuson formation consists of a series of fine-grained deposits lying between the Dakota and the Lakota sandstones and encircling the Black Hills. Its thickness averages about 65 feet, but varies considerably and is greatest in the northern hills. Its material consists of a mixture of clay and fine sand, as a rule massively bedded. Some beds of coarser sandstone are locally included, but most portions are nearly pure shale. The predominant color is white or gray, but in many places buff, purple, and maroon tints are conspicuous.

As the formation is relatively soft compared with adjoining sandstones, it usually gives rise to a depression between a low crest of Dakota sandstone on the one hand and the higher summits of the Lakota sandstone on the other. Locally it is covered by talus from the sandstone cliffs above. One of the most extensive exposures is at the falls of Cheyenne River, where the section is as follows:

Section of Fuson formation at falls of Cheyenne River, south of Hot Springs.

Dakota sandstone.

Dark sandy shale................................ ${ }_{4}^{4}$

Soft gray slabby sandstone; plants...................... 6

Compact white mudstone............................ 8

Dark-green clay ..................................... 1

Dark-gray compact mudstone.......................... 25

Very compact white mudstone......................... $2 \frac{1}{2}$

Gray mudstone................................... $\quad 6$

Harder white mudstone............................ 9

Purplish shale..................................... 1

White fine-grained sandstone........................... $5-12$

Purple shale................................... 6-8

Light-buff massive sandstone.......................... 25

Dark-buff coarser sandstone, much honeycombed by weathering... 25

Outcrops of the formation are considerably obscured by talus along the canyon of Fall River, but there are extensive exposures in the side canyons, notably in one on the steep side of the anticline 2 miles due east of Hot Springs, where much of the material is bright purple and strongly resembles a shale that has been subjected to heat. 
Fuson Canyon affords some striking exposures of a portion of the formation in cliffs capped by Dakota sandstone. The uppermost bed is a moderately hard sandstone underlain by 10 feet of purplishgray shales, 10 feet of white mudstone, and 20 feet of bright-purple shale. On Dry Creek the formation is represented by 50 feet of white massive shale. On Squaw Creek the Lakota sandstone is overlain by about 50 feet of buff and purple shale, grading upward to the Dakota sandstone through several feet of shale and thin sandstone. Northwest of Hermosa shales of bright color prevail, much of the material being purple. Near Rapid it is 100 feet thick, and near Sturgis 65 feet. Farther north it varies from 65 to 100 feet. On the south and north sides of the hills the formation is at many places mixed with considerable sand and sandstone. In the Hay Creek region it has yielded large numbers of fossil plants of Lower Cretaceous age.

\section{DAKOTA SANDSTONE.}

The formation here designated the Dakota sandstone is the uppermost member of the series formerly designated "Dakota sandstone" in the Black Hills region. It extends continuously around the uplift, but being rarely more than 100 feet thick it constitutes only a small part of the hogback range. Nevertheless it is conspicuous, because the foothills to which it usually gives rise ascend steeply out of the adjoining valley or level plain underlain by the Graneros shale. It generally consists of gray sandstone, weathering brown. It is hard and massive below, but thinner bedded above. The fossil plants which have been obtained from it are impressions of dicotyledonous leaves, regarded as Upper Cretaceous in age.

\section{BENTON GROUP.}

Graneros shale.-The Graneros shale, which is the lowest formation of the Benton group, extends entirely around the Black Hills uplift, with a course marked by lowlands and valleys. It consists of dark fissile shale 900 to 1,150 feet thick, the maximum amount being north of Belle Fourche. From Edgemont to Sturgis the average amount is 900 feet.

In some areas the formation contains, toward its base, a thin layer of hard sandstone, which rises in a ridge of considerable prominence near Rapid, Hermosa, Newcastle, and Belle Fourche. It occurs locally, but apparently at the same horizon, from 150 to 300 feet above the Dakota sandstone. Its maximum thickness is about 30 feet. At Hermosa, where it is traceable from 4 to 5 miles, it is about 200 feet above the base of the formation and attains a thickness of 15 feet. At Rapid it is again conspicuous, but near Belle Fourche it is thin, soft, and in places absent. 


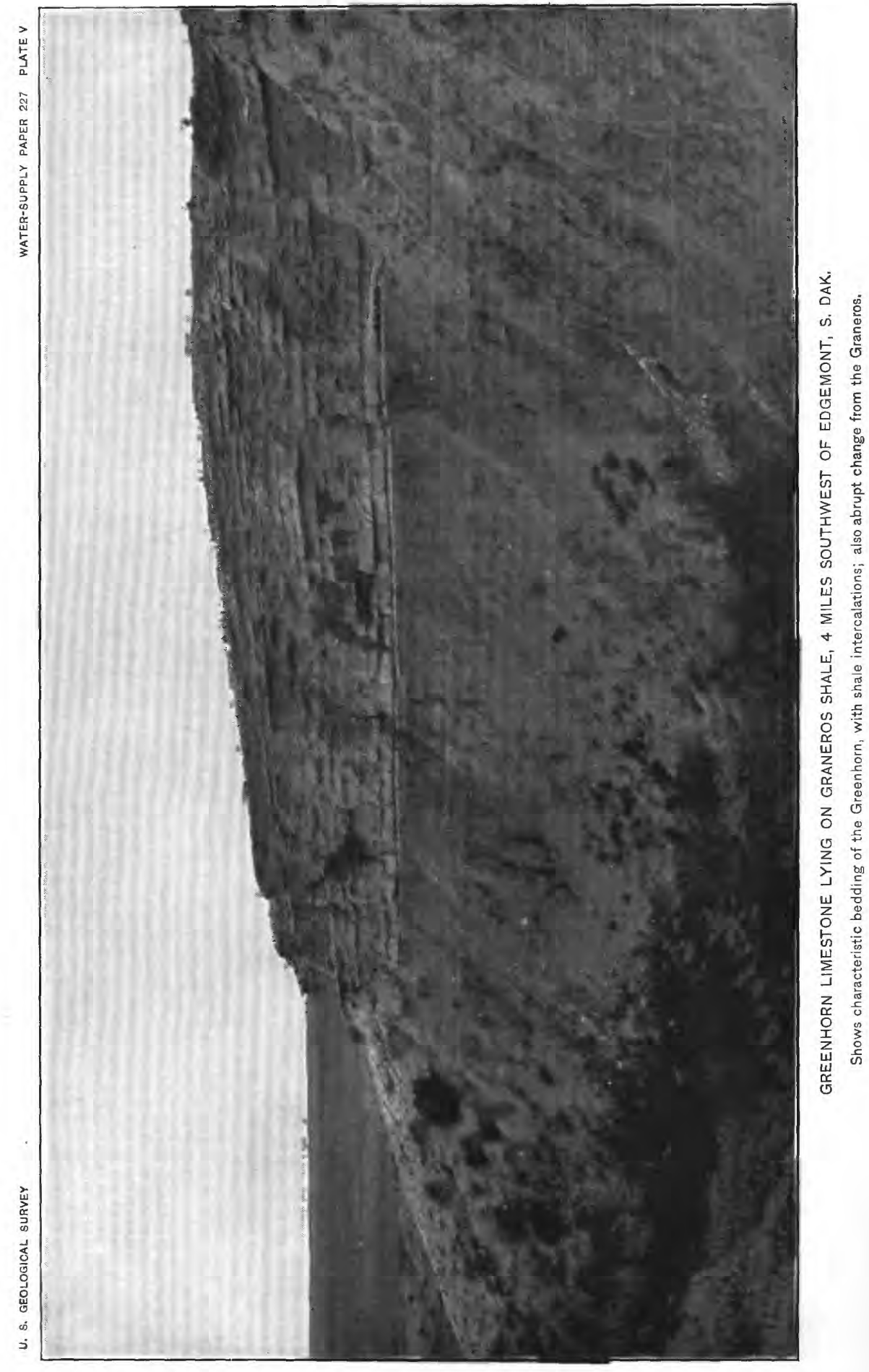



Next above this sandstone horizon is a series of hard gray shales known as the Mowry shale member. It is from 100 to 250 feet thick, and owing to its hardness gives rise to ridges of moderate prominence, many of which bear scattered pine trees. The shales of this member contain large numbers of fish scales and weather to a light silvery color, both characteristic features.

Greenhorn limestone.-One of the most prominent features in the plains immediately adjoining the Black Hills is a low but distinct escarpment, due to a hard limestone bed in the middle of the Benton group. It usually lies from 1 to 4 miles distant from the hogback ridge of the Dakota sandstone and presents its face toward the hills. It is thin but persistent, and is characterized by large numbers of impressions of Inoceramus labiatus, a fossil of scanty occurrence in the adjoining formations. It is believed to represent the Greenhorn limestone of Arkansas Valley.

The Greenhorn limestone contains a considerable amount of clay and fine sand. It appears to gain hardness on weathering, breaking. into hard, thin pale-buff slabs covered with impressions of the distinctive fossil. Its thickness averages about 50 feet. At its base it is usually distinctly separated from the dark Graneros shale (see Pl. V), and in its upper portion it appears to grade into the Carlile shale through 6 or 8 feet of passage beds.

The most extensive exposures of the Greenhorn limestone are in the prominent escarpments west and northwest of Edgemont, which rise high above the slopes extending along either side of Cheyenne River. Owing to the low dip in this vicinity the limestone is spread out in plateaus extending back for some distance from the edge of the escarpment. In the region about Fairburn the formation is traversed by a syncline, which spreads it out into a bifurcated ridge south of the town. On the adjoining divides, notably in those between French Creek and Battle Creek and between Battle Creek and Spring Creek, the formation is buried beneath the overlapping White River deposits. It is well exposed in the banks of Battle Creek $1 \frac{1}{2}$ miles below Hermosa, where, in its only slightly weathered condition in the fresh stream cut, it is seen to be a hard calcareous light-gray shale filled with Inocerami. In the northern Black Hills it is a conspicuous feature about Belle Fourche, notably in a prominent butte known as Susie Peak.

Carlile shale.-The Carlile shale, which is the uppermost formation of the Benton group, consists of dark fissile shale with concretions, thin sandstones, and impure limestone layers, lying between the Greenhorn limestone and the Niobrara formation. Near the top of the formation numerous oval concretions occur, containing Prionotropis, Prionoycclus, and other fossils. The thickness ranges from 
500 to slightly more than 750 feet, the larger amount being in the region north of Belle Fourche. Some typical sections are as follows:

Section of Carlile shale near Buffalo Gap.

Niobrara formation.

Foet.

Shales, with large buff concretions........................ 150

Hard slabby sandstone................................ 2

Gray shale.......................................... 130

Thin coarse sandstone.............................. 4

Gray shale......................................... 75

Concretions in gray shale.............................. 2

Gray shale..................................... 40

Calcareous sandstone with Ostrea, etc.................... 4

Shale and talus....................................... 180

Greenhorn limestone.

Section of Carlile shale $1 \frac{1}{2}$ miles southeast of the falls of Cheyenne River.

Niobrara formation. Feet.

Gray shale, with large buff concretions.................. 50

Gray shale.......................................... 70

Light-gray sandstone................................ 4

Dark-gray shale, with thin sandy layers . . . . . . . . . . . 160

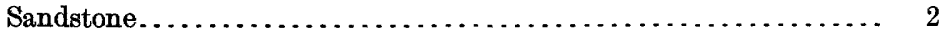

Gray shales............................................ 150

Greenhorn limestone.

NIOBRARA FORMATION.

The calcareous deposits of the Niobrara formation completely encircle the Black Hills, presenting distinctive features throughout, but to a less degree in the northeast than in the south. The material is a soft shaly limestone or impure chalk, containing greater or less admixture of clay and fine sand. In unweathered exposures it is generally light gray, but its weathered outcrops have a bright-yellow color which usually renders them conspicuous, although, owing to the softness of the materials, they give rise to few noticeable ridges. The thickness of the formation is about 225 feet in the central and southern Black Hills and 150 to 200 feet on the northern slopes. At many places thin hard layers are included, consisting of an aggregation of shells of Ostrea congesta, a fossil distinctive of the formation where it occurs in this manner.

\section{PIERRE SHALE.}

Many thousand square miles of the country adjoining the Black Hills are occupied by the Pierre shale. This formation is a thick mass of dark-colored shale, weathering light brown, and is relatively uniform in composition throughout. It gives rise to a dreary monotony of low rounded hills, sparsely covered with grass and not very 
useful for agriculture. The thickness of the formation is 1,200 to 1,400 feet, so far as can be ascertained, but only at a few places can it be measured. Where it dips gently away from the hills it is almost impossible to measure the rate of the dip of the shale. Fortunately it has been found that the formation includes, at a horizon about 1,000 feet above its base, scattered lenses of limestone usually containing numerous shells of Lucina oceidentalis. The greater number of these lenses occur at the definite horizon just mentioned, and in some places, where they occupy the surface over a wide area, they throw light on the attitude of the formation. It is evidence of this sort that provides a basis for the determinations of structure which afford an important part of the data for ascertaining the depth of the Dakota sandstone in the region adjoining the Black Hills.

The limestone concretions with Lucina vary in size from those of 2 or 3 cubic feet to masses 20 feet in diameter and 6 or 8 feet thick, usually of irregular lens shape. Owing to their hardness these lenses, when uncovered by erosion, give rise to low conical buttes resembling in form very squat tepees, and accordingly they have been designated "tepee buttes," a term used for similar occurrences in the Pierre shale of southeastern Colorado. They occur in large numbers in the vicinity of Oelrichs, east of Hermosa and Sturgis, and in the Willow Creek valley, varying in height from 10 to 150 feet above the surrounding slopes. Horizontally the lenses occur at irregular intervals, so that the buttes are scattered very erratically and some of them are separated by many miles.

Numerous concretions occur in the Pierre shale at various horizons and usually contain large numbers of distinctive fossils. Baculites compressus, Inoceramus sagensis, Nautilus dekayi, Placenticeras placenta, and Heteroceras nebrascensis are the more abundant, and Lucina occidentalis is found here and there. The most fossiliferous horizon is in the upper part of the formation. The concretions are generally small and of a calcareous nature, and they break into brown pyramidal fragments which are scattered more or less thickly all over the Pierre surfaces.

In the southern part of the Black Hills region there is, at the base of the formation, a very distinctive series of black, splintery, fissile shales, containing three beds of concretions. These shales have been included in the Pierre, though not yet found to contain distinctive fossils; they may be Niobrara. They are about 150 feet thick in the Edgemont-Oelrichs region, where they give rise to a steep slope, in places rising conspicuously above the lowlands eroded in the Niobrara chalk. The concretions exhibit a curious sequence. The lower ones are biscuit-shaped, hard, and siliceous; those in the layers next above are similar in shape and composition, but are traversed in every direction by deep cracks filled with calcite and locally scattered 
crystals of barite; and those in the uppermost layers are large, lensshaped, highly calcareous, and of a light-straw color, consisting mainly of well-developed cone-in-cone.

FOX HILLS SANDSTONE.

The sandstone of Fox Ridge extends westward to the margin of the Black Hills uplift, and outliers of it cap portions of the high divides between Cheyenne and Bad rivers and between Belle Fourche and Owl rivers.

\section{TERTIARY SYSTEM.}

\section{WHITE RIVER GROUP.}

The well-known formations of the Big Badiands lying between Cheyenne and White rivers in western South Dakota and underlying Pine Ridge have been found to extend to the Black Hills and high up on their flanks in a portion of the region. About Fairburn and Hermosa wide areas of the highlands are occupied by the Chadron formation and the Brule clay, which give rise to numerous miniature badlands of considerable extent. The deposits comprise both finegrained and coarse-grained materials, the latter marking the course of the more vigorous streams of the period. There are large areas of fuller's earth, sand, limestone, calcareous grit, and channels filled with conglomerate, in some places silicified and in others cemented by carbonate of lime.

The principal areas now remaining are on the high divides between Lame Johnny and Rapid creeks, but there are also extensive masses in the broad part of the Red Valley behind the hogback range, and narrow valleys filled with the deposits extend several miles back over the Carboniferous and Cambrian onto the Algonkian crystalline rocks. Some details of their distribution are shown on the geologic map (Pl. I). To the southwest there are scattered areas at a number of points between Edgemont and Pringle, notably on the Minnelusa sandstone west of Argyle, in the Red Valley north and west of Minnekahta, and on the Dakota sandstone not far north of Edgemont. South of Oelrichs there is a narrow basin which has been preserved in a syncline extending toward the Big Badlands.

The deposits of the White River group exhibit considerable diversity of composition. The principal material is a porous, crumbling clay, pale flesh color when dry, but light brown when damp. Some portions of it are pale green when dry and olive when wet. Much of it is fuller's earth, and differs from ordinary clay in being much less plastic. In the lower beds of the group it merges into sand on the one hand and into clay on the other. At many localities it is associated with or gives place to coarse materials occupying channels or broad sheets. In the vicinity of Hermosa the principal material is 


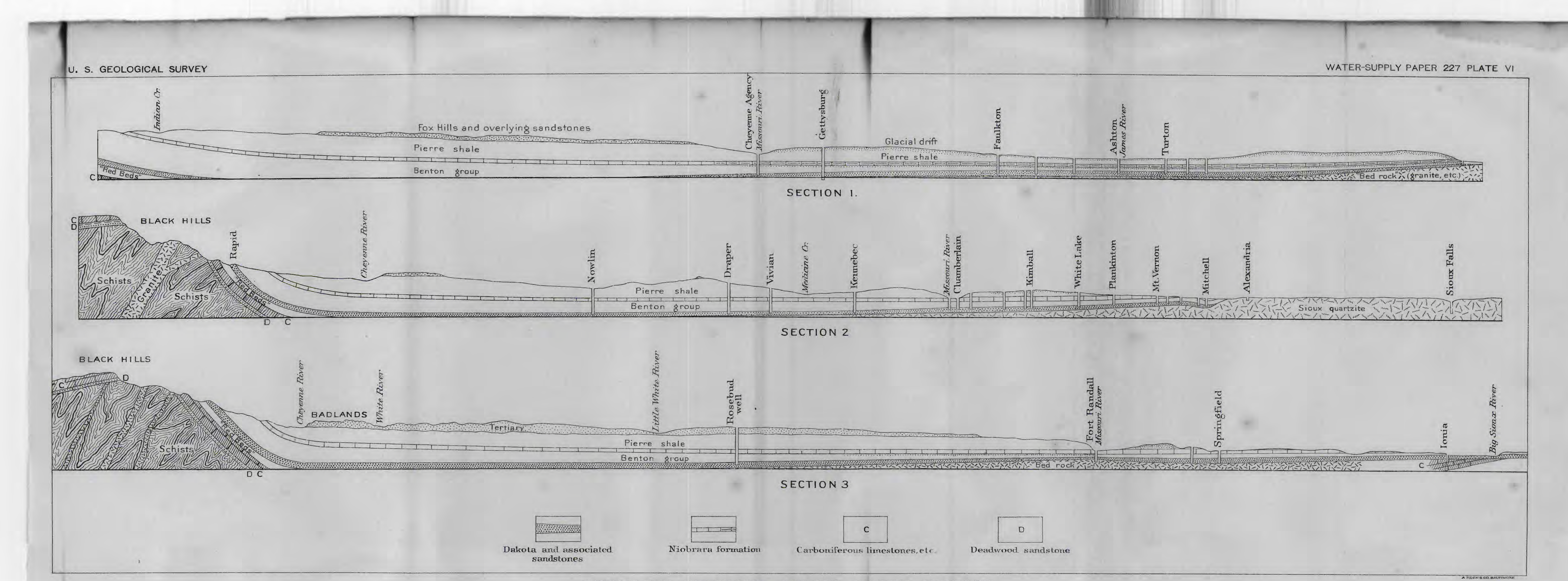

GEOLOGIC SECTIONS ACROSS SOUTH DAKOTA

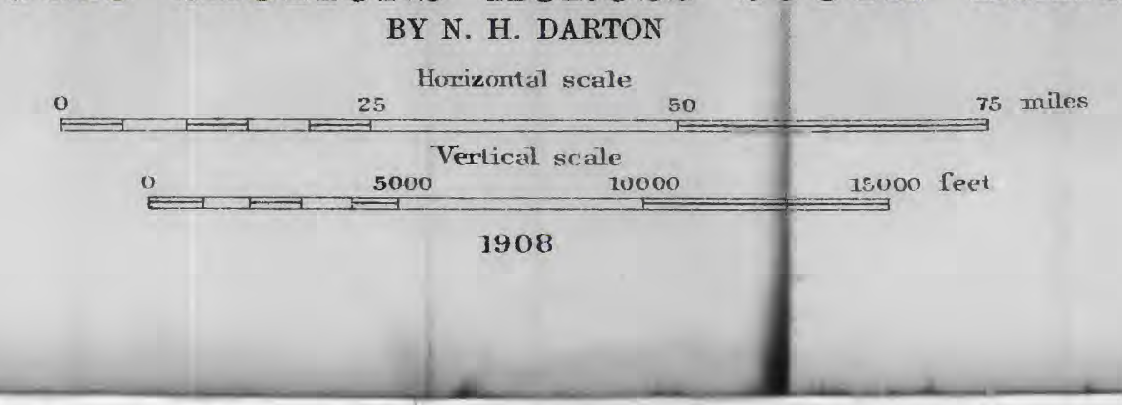


coarse sandstone and conglomerate, mainly of dark-brown color, which mantles extensive plateaus. On the high level ridge north of Spring Creek there are coarse conglomerates, which extend entirely across the hogback range. About Fairburn and to the west there are long channels filled with conglomerate consisting of limestone pebbles and a calcareous matrix. These extend up several of the depressions through the hogback range, either displacing the fuller's earth deposits or being intercalated among them. The limestone pebbles appear to have been derived from Tertiary limestones, for they do not represent any of the Mesozoic or Paleozoic rocks of the hills. On the higher lands of the Red Valley, between Hermosa and Rockerville, there is an extensive deposit of nearly pure limestone, giving rise to a high plateau of considerable extent. The total thickness of the rock is about 30 feet at some places, the limestone being underlain by fuller's earth.

Limestones of various degrees of purity are abundantly intercalated in fuller's earth deposits which lie in depressions on the older rocks in the region west and southwest of Fairburn. Their most southerly occurrence is on the ridge a short distance northwest of the western entrance of Fuson Canyon and on the high divide just north of Lame Johnny Creek, a short distance west of the Chicago and Northwestern Railway. These limestones usually contain abundant fresh-water fossils, mainly gasteropods, at many places in great abundance.

There are extensive exposures of coarse materials of White River age in the railroad cuts through the divide south of Fairburn, where the materials are mainly cross-bedded coarse sands, with a large proportion of gravel, chiefly derived from the crystalline rocks of the hills. The thickness of the White River deposits on the flanks of the Black Hills varies from a thin remnant to 200 feet or more. In the divide just south of Lame Johnny Creek, in the Red Valley, at a point 10 miles southwest of Fairburn, more than 200 feet was measured, the deposit consisting mainly of pale flesh-colored sandy clay and fuller's earth.

The deposits of the White River group are usually divisible into two formations-the Chadron formation or so-called Titanotherium beds below and the Brule clay (including the so-called Oreodon beds) above. The Chadron formation consists of light-gray fuller's earth, and usually has at its base a bed of coarse gravel composed of rocks derived from the Black Hills. The Brule clay consists mostly of massively bedded sandy clay of pale flesh and drab colors.

All the White River beds have yielded fossil bones of various kinds which are typical of the Oligocene period.

The White River deposits southwest of Argyle consist mainly of fuller's earth of the Chadron formation. North and west of Minnekahta the material is a mixture of fine sand and clay. The outlier north- 
west of Edgemont caps an area of Graneros shale high on the slope of the Dakota sandstone. It consists mainly of gray conglomeratic sandstone. In the vicinity of Lead and Garden small areas of White River strata have been found at an altitude of about 5,100 feet.

During White River time in the Black Hills and adjoining regions a considerable volume of volcanic ash was deposited. The epoch appears to have been one of volcanic activity in the region to the west, and the ashes were borne on the winds and dropped into the waters so as to be spread over a wide area of country adjoining the Black Hills. More or less volcanic ash occurs throughout the White River deposits as an admixture with the clay and sand. Accumulations of the pure material are found at various horizons.

\section{GEOLOGY OF SOUTH-CENTRAL SOUTH DAKOTA.}

\section{GENERAL RELATIONS.}

The portion of South Dakota lying south of Cheyenne River, between Missouri River and the Black Hills, is occupied by the Pierre shale and Tertiary deposits. On the divide at the head of Bad River there is an outlying area of Fox Hills sandstone. The Pierre shale extends along both sides of the Cheyenne River valley and southeastward to and beyond the middle and lower portions of the White River valley. It is also exposed along the Keyapaha. It consists of 1,000 feet or more of dark-gray shales, mostly soft and lying nearly horizontal. Missouri River cuts through them from the big bend southward, exposing the underlying Niobrara formation. The structure, as shown in sections 2 and 3, Plate VI, is a very gentle syncline, with the eastern side lower than the western. Wells at Capa and Nowlin penetrate the Pierre and underlying formations to the Dakota sandstone. This rock lies 1,500 feet below the surface at Capa and 1,770 feet below at Nowlin. It is overlain by about 1,000 feet of Benton and Niobrara, but the thickness of these beds was not determinable from the meager reports of the materials penetrated in boring. The 2,500-foot boring northeast of Rosebud entered the Pierre shale at 350 feet and passed through that formation and underlying beds to the Dakota sandstone, as shown in the record on page 132.

TERTIARY DEPOSITS.

The higher lands of south-central South Dakota are mantied by deposits of Oligocene and Miocene age. These reach a maximum thickness of about 600 feet near the head of South Fork of White River, but the amount is much less in most other portions of the area. The deposits lie on the Pierre shale except for local overlaps onto the Fox Hills sandstone at the head of Bad River and onto the Niobrara formation in the uplift south of Slim Buttes. It is probable that originally the entire region was covered by Tertiary deposits that extended 


\section{s}

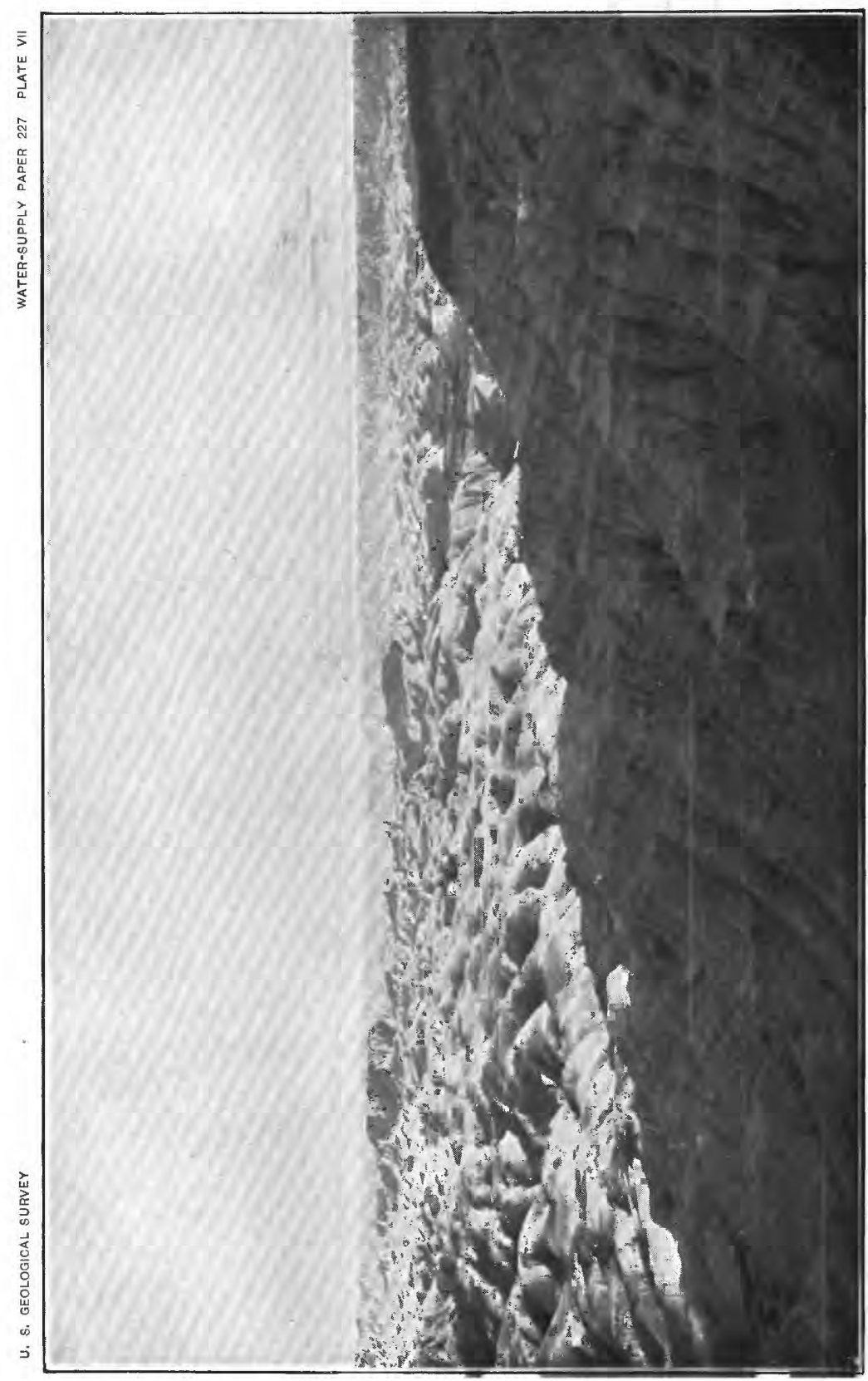

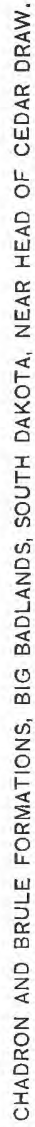



far to the northeast and west. This is indicated by the presence of outliers, notably those high on the slopes of the Black Hills.

The Tertiary consists of two principal subdivisions-the White River group (Oligocene) below and the Arikaree formation (Miocene) above-the distribution of which is shown on the geologic map (Pl. I). To the east and north the White River group thins and is overlapped by the Arikaree, apparently owing to progressively greater erosion of the former before the latter was deposited.

The White River group has been studied mainly in the Big Badlands between Cheyenne and White rivers, where three principal subdivisions were recognized-the lower one the Chadron formation or so-called Titanotherium beds (see Pl. VII), the middle the Brule clay or so-called Oreodon beds, and the upper a series of clays underlain by the Protoceras sandstone (see Pls. VIII, $A$, and IX, $A$ ), as it has been called. In the Brule clays there is at many places a marked sandstone horizon known as the Metamynodon sandstone. The upper limits of the Brule clay have not yet been settled. In 1900 it was discovered that in the higher slopes southeast of White River, in the western portion of the Pine Ridge Reservation, the Protoceras horizon is overlain by several hundred feet of clays and sandstones which were regarded as the top member of the White River group, for they are immediately overlain by the Arikaree formation in Pine Ridge. They are shown in Plate IX, $A$.

The upper beds in this area have been further described by W. D. Matthew, ${ }^{a}$ who has discovered lower Miocene vertebrates in a member which he has named Rosebud. A. B. Reagan ${ }^{b}$ has described the relations in the central part of the Rosebud Reservation.

\section{GEOLOGY OF NORTHWESTERN SOUTH DAKOTA.}

\section{GENERAL OUTLINE.}

Very little information is available on the geology of the northern portion of Butte County and of the Cheyenne River and Standing Rock Indian reservations. Several expeditions have passed across portions of the area and ascertained some of its geologic features. F. V. Hayden visited the eastern and southern parts of the region in 1854 and reported that it was occupied mainly by the Fox Hills and Laramie formations. In the lower lands adjoining Missouri and Cheyenne rivers the Pierre shale appears. In $1874 \mathrm{~N}$. H. Winchell c crossed the western part of Butte County with the Ludlow expedition and recorded a wide area of "Laramie" to the north, succeeded by the Pierre and Benton as Belle Fourche River was approached. Outliers of Tertiary formations were noted on some of the high divides east of the Little Missouri, 


\section{FORT UNION, LARAMIE (?), AND FOX HILLS FORMATIONS.}

In 1884 Bailey Willis ${ }^{a}$ examined the region extending from Grand River to Owl (Moreau) River, in the southwest corner of the present Standing Rock Indian Reservation. The rocks were classed as Laramie and Fox Hills formations, the latter grading downward into the upper portion of the Pierre shale. The uppermost formation, occupying the central divide between the two rivers, consists of lightyellow, gray, and dark-brown sandstones and sandy shale, with thin beds of lignite and iron nodules. On Cottonwood and Thunder creeks it was found to contain thick beds of fossils, including Ostrea glabra and Melania insculpta. Beds of lignite found at various localities are less than 3 feet thick, but there are numerous thin beds. There also occur numerous nodules of gray carbonate of iron. The strata are practically horizontal, but local dips of $1^{\circ}$ to $3^{\circ}$ are indicated in places, and the thickness of the rocks is estimated at about 700 feet. Next below the so-called Laramie are brownish sandstones which yielded Tancredia americana at the lower crossing of Flint Creek. Apparently the succession is regular, as no evidence of unconformity was noted. Next below are brownish sandstones without fossils, underlain by grayish-blue shale containing various Fox Hills fossils, which were collected on Owl River one-half mile below the mouth of Thunder Creek. These Fox Hills beds have an estimated thickness of 100 feet. They are underlain by dark-gray to blue-black tenacious clay, with local harder layers, and contain fossils regarded as transitional between the Pierre and the Fox Hills. These beds were examined on Grand River 15 miles east of the mouth of Flint Creek. The so-called Laramie beds appear first in isolated buttes on the divide 30 miles west of the Missouri, or near the head of Flint Creek.

In the summer of $1895 \mathrm{~J}$. E. Todd made a reconnaissance of a portion of the region lying west of longitude $103^{\circ}$ and his report ${ }^{b}$ contains many important facts. He reported that the country north of South Fork of Owl River was occupied by Laramie and associated sandstones with detached high buttes capped by Tertiary deposits. One of the most extensive sections examined was at the south end of the North Cave Hills, where the following beds were measured:

\section{Section at south end of North Cave Hills.}

Yellow fine-grained quartzite or flint with casts of plant stems. . 2

Whitish marl with thin layers of limestone above............ 18

Purple massive sandstone............................. $\quad 27$

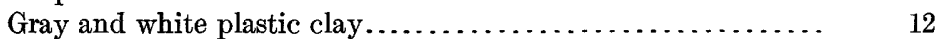

Yellow massive sandstone........................... $\quad 50$

Soft yellow stratified sand............................. $\quad 16$

$a$ Lignites of the Great Sioux Reservation: Bull. U. S. Geol. Survey, No. 21, 1885.

$b$ First and second Biennial Repts., South Dakota Geol. Survey, 1893-96, Vermilion, 1898. 


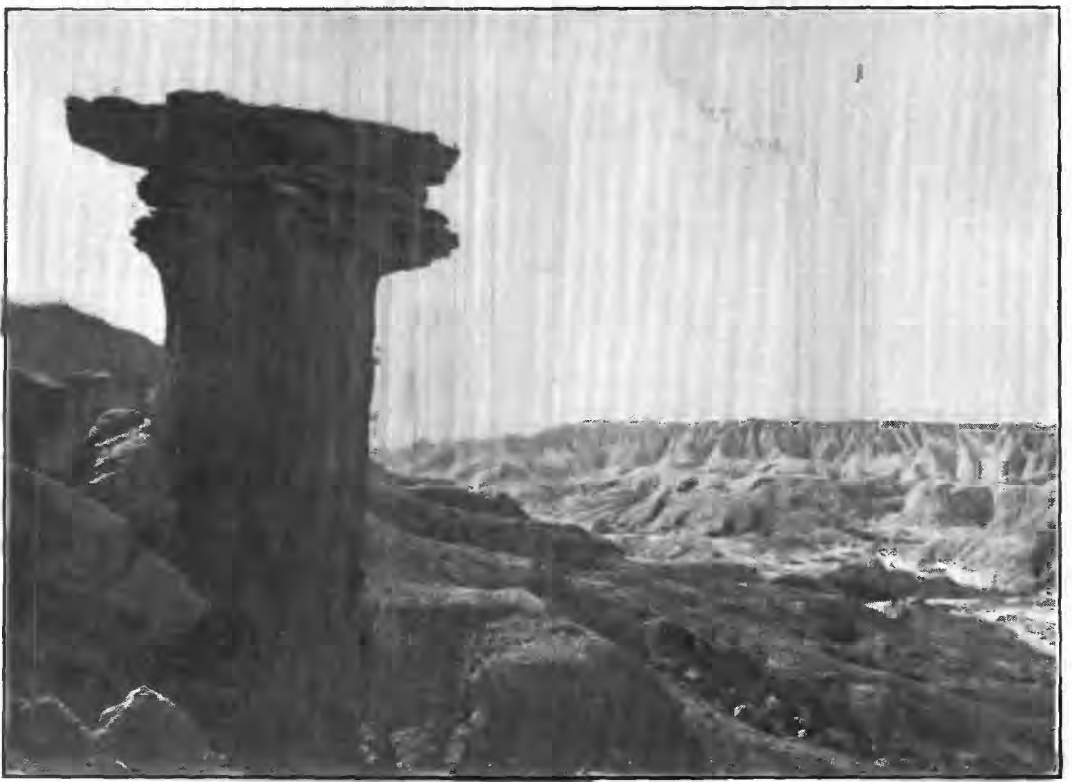

A. CENTRAL PORTION OF BIG BADLANDS: COTTONWOOD CRAW, SOUTH DAKOTA.

Shows middle members of White River group; Protnceras sandstone capping pillar at left.

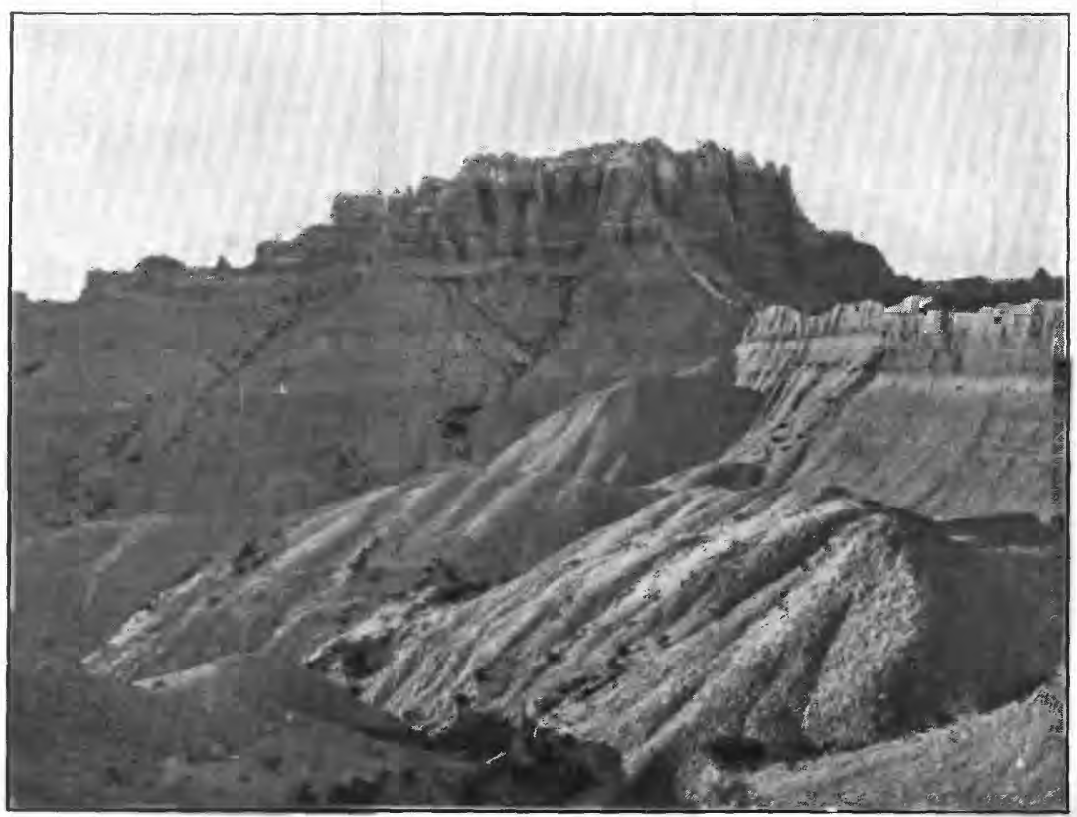

B. SPUR AT SOUTH END OF SHEEP MOUNTAIN, BIG BADLANDS, SOUTH DAKOTA.

Brule clay and White River beds: volcanic ash at top. 
Hard sandstone. . . . . . . . . . . . . . . . . . . .

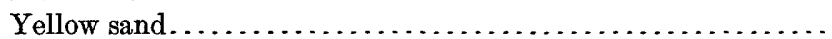

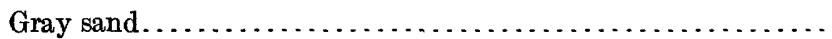

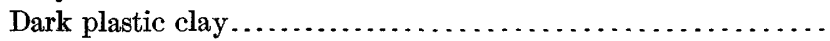

Lignite.

Dark plastic clay

Good lignite

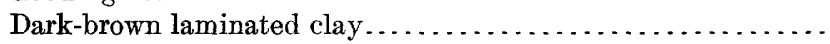

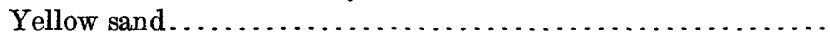

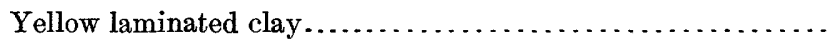

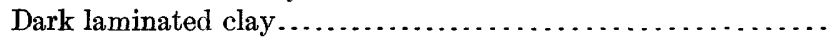

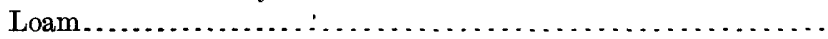

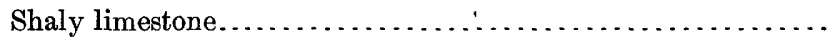

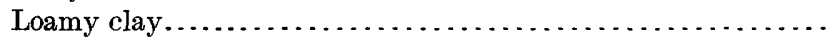

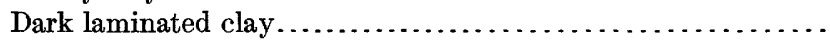

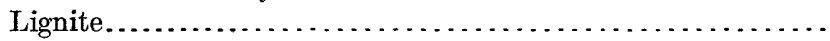

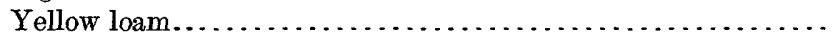

Laminated, ripple-marked concretionary limestone...........

Cream-colored laminated silt.........................

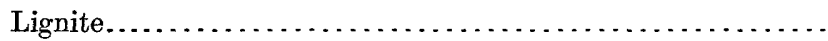

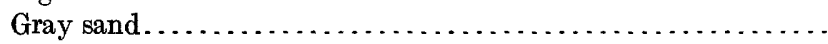

Laminated clay with lignite in the middle..............

Light-colored sandy silt. . . . . . . . . . . . . . . . . . .

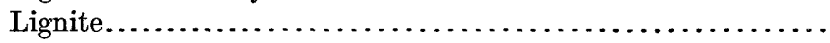

Cream-colored sandy silt, with some yellow calcareous sand-

stone concretions. . . . . . . . . . . . . . . . . . . . . . . .

Dark laminated clay with 2 -inch carbonaceous layer at top.....

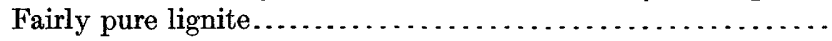

Light cream-colored silt. . . . . . . . . . . . . . . . . . . .

Light-colored silt with flat concretions at the top...........

Dark laminated shale, about half of it impure lignite.........

Very light laminated shale.......................

Black shale..................................

Light coarse sand, some small concretions................

Plastic clay with three black bands of lignite.............

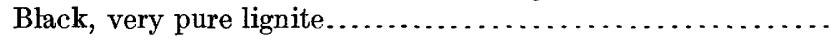

Light clay ..............................

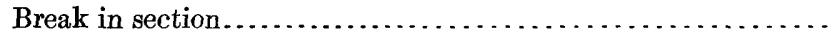

Cream-colored silt, stratified.......................

Thin shaly calcareous sandstone...................

Brown and gray clay silt. . . . . . . . . . . . . . . . . . . .

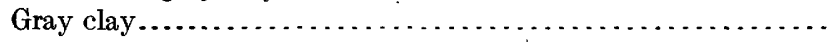

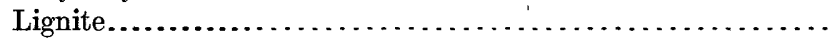

Silt slope................................

Carbon streak with alkali. . . . . . . . . . . . . . . . . .

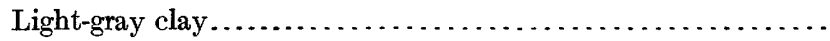

Obliquely laminated rusty sandstone..................

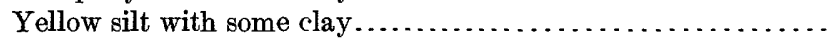

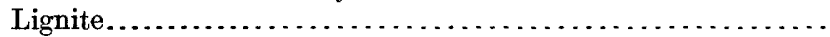

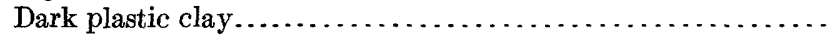

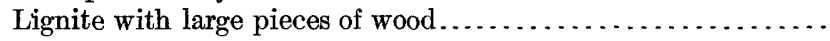

Slope with alkali clay.

$4 \frac{1}{2}$
4
5
6
15
4
3
$\frac{1}{4}$
10
7
$3 \frac{1}{2}$
3
$30-35$
5
1
14
1
$\frac{1}{2}$
9
$\frac{1}{2}$
6
1
8
$\frac{1}{4}$
10

The two upper beds are regarded as the White River formation. 
It was found that the greatest development of sandstone is in the vicinity of Cave Hills, and that it thins toward the south and east. The beds composing the lignitic formation, however, are very variable in stratigraphy, and sections a few miles apart show great difference in components. The lignite beds occupy extensive areas, but they change rapidly in thickness and quality and are not all favorably located for mining. The most extensive deposit is the bed 5 to 7 feet thick lying from 150 to 200 feet below the top sandstone. This was traced eastward for 25 or 30 miles along the valley of North Fork of Grand River. Another thick bed occurs 100 to 125 feet lower, but the two are found in the same section only at the south end of the Cave Hills. Two thick beds occur at Florman's coal camp in or near sec. 23 , T. 18 N., R. 7 E. At this place the following section is presented:

Section of coal measures in or near sec. 23, T. 18 N., R. \%. E.

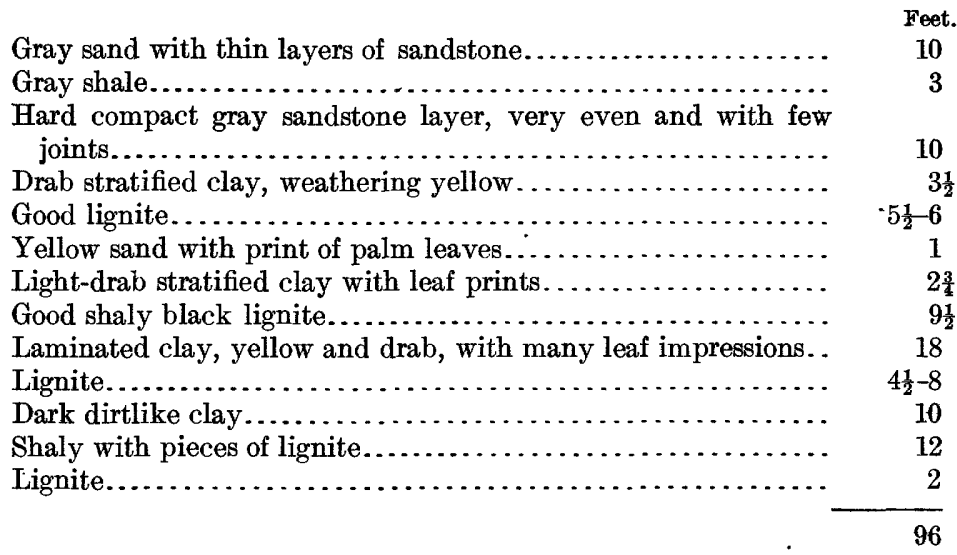

The two coal beds in this section may correspond with those in the Cave Hills. The uppermost beds of the formation are at many places unconsolidated, and contain elongated concretions closely resembling saw logs in size, shape, and appearance. Some of these are from 50 to 100 feet long. The so-called Laramie includes all the strata in the Cave Hills, with the exception of the two upper members, all in the Slim Buttes below and including the rusty sandstone, all in the Deers Ears except an 8-foot cap of Tertiary conglomerate, and all of the East Short Pine Hill except the basal portion, which is supposed to be Pierre shale. No Fox Hills fossils were found, but if there is no unconformity between the Pierre and the socalled Laramie, doubtless sediments of Fox Hills age are represented.

Through recent work of A. G. Leonard ${ }^{a}$ it is reasonably certain that the principal lignite-bearing beds of the northwestern part of the State are the same as those exposed in the valley of Little Mis-

a The North Dakoța-Montana lignite area: Bull. U. S. Geol. Survey No. 285, 1906, pp. 316-330. 


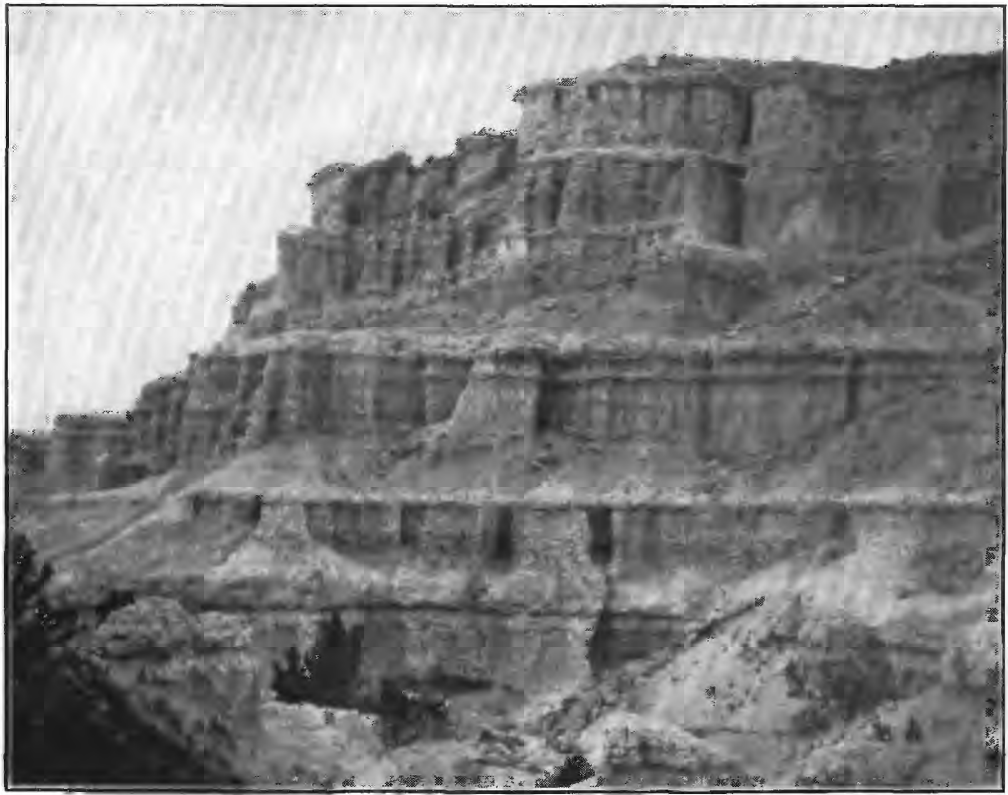

A. UPPER MEMBER OF WHITE RIVER GROUP, WOUNDED KNEE CREEK, SOUTH DAKOTA.

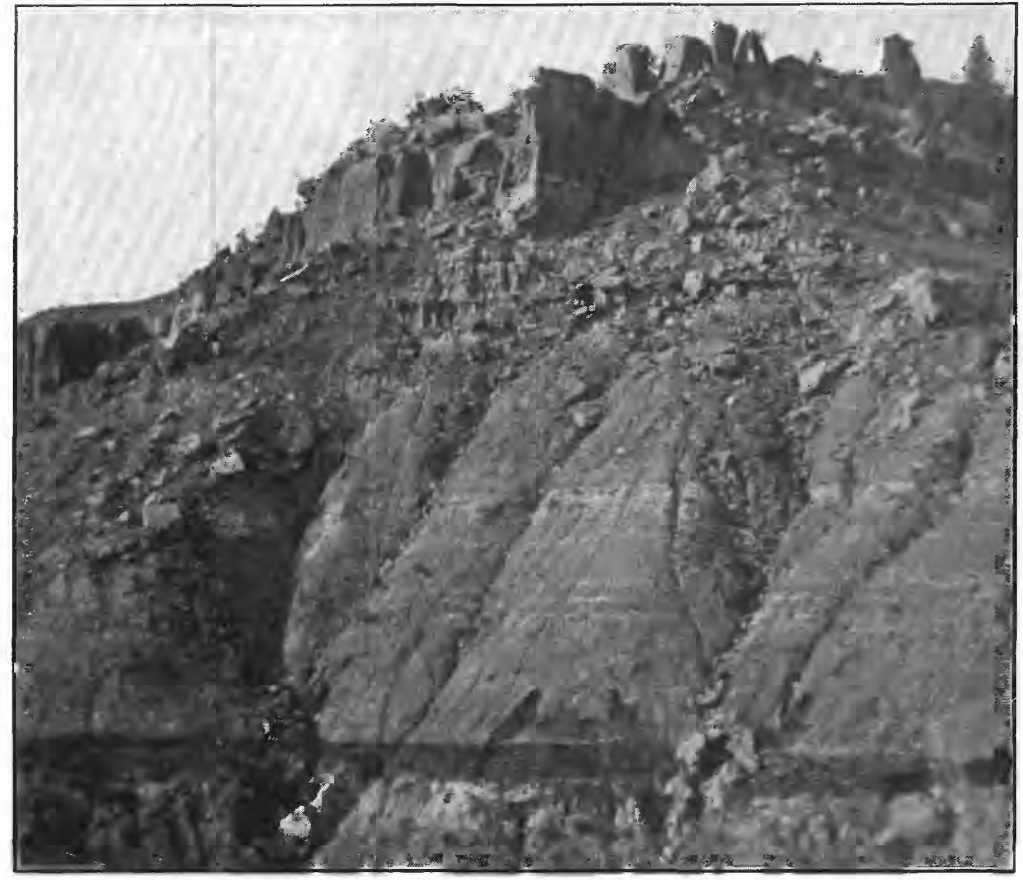

b. LIGNITIC BEDS AT SOUTH END OF NORTH CAVE HILL, BUTTE COUNTY, S. DAK. Shows 5 -foot bed of lignite near base. (Photograph by J. E. Todd.) 

souri River in the vicinity of Medora, N. Dak. Knowlton and Peale believe that the latter are of Fort Union age, and the lignitebearing beds of South Dakota are presumably of the same age.

\section{POST-EOCENE.}

Outliers of Tertiary deposits cap a number of high buttes on the divides between the Belle Fourche, Owl, Grand, and Little Missouri valleys. The most notable of these features are Castle Rock, Haystack, Slim, and Deers Ears buttes, and Cave and Short Pine hills. These hills rise several hundred feet from the rolling prairie of the lignite-bearing formation, which varies in altitude from about 3,000 to 3,500 feet. The deposits lie unconformably on that formation, and appear to belong largely to the White River group. In Slim Buttes and the Short Pine Hills they are capped by beds which are described by Todd as "Loup Fork," but which should probably be assigned to the Arikaree formation.

The White River beds have a thickness of about 100 feet in Slim Buttes, and consist mostly of gray clays, with thin layers of sandstone and sand. In places the sandstones thicken. Near the north gap in these buttes the beds are tilted at angles of $12^{\circ}$ to $25^{\circ} \mathrm{S}$. and SW. They are overlain by nearly horizontal Arikaree (?) beds. The White River deposits contain a large amount of flint, with irregular cavities, evidently due to plant stems, one-sixteenth inch to 4 inches in diameter, some of them with fossil wood still remaining. Thin deposits of gray to yellowish impure opal and thin veins and scattered masses of chalcedony also occur. Bones of Oligocene animals, including Titanotherium, Oreodon, and turtles, are reported. The overlying Arikaree (?) beds consist mostly of fine-grained white friable sandstone containing small globular concretions. Some portions are cemented by carbonate of lime and other portions with silica, the latter giving rise to a hard quartzite at a few localities. The thickness at the north end of Slim Buttes is 125 feet; in the Short Pine Hills it is about 200 feet. No fossils were observed. The following sections by Todd show the principal local features:

Section of White River group at southeast angle of Slim Buttes.

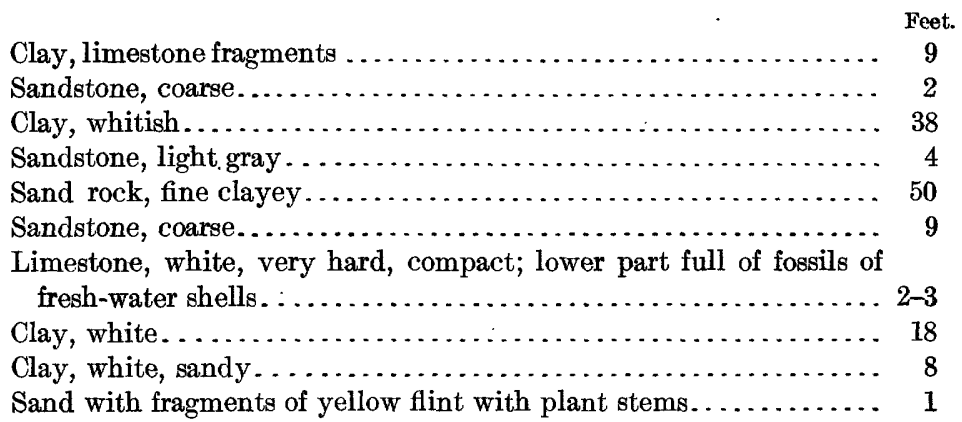


The limestone evidently is similar to that which occurs near the base of the Oreodon beds in the Big Badlands and elsewhere.

Section of Tertiary deposits on northwest side of Slim Buttes, near Florman's coal camp.

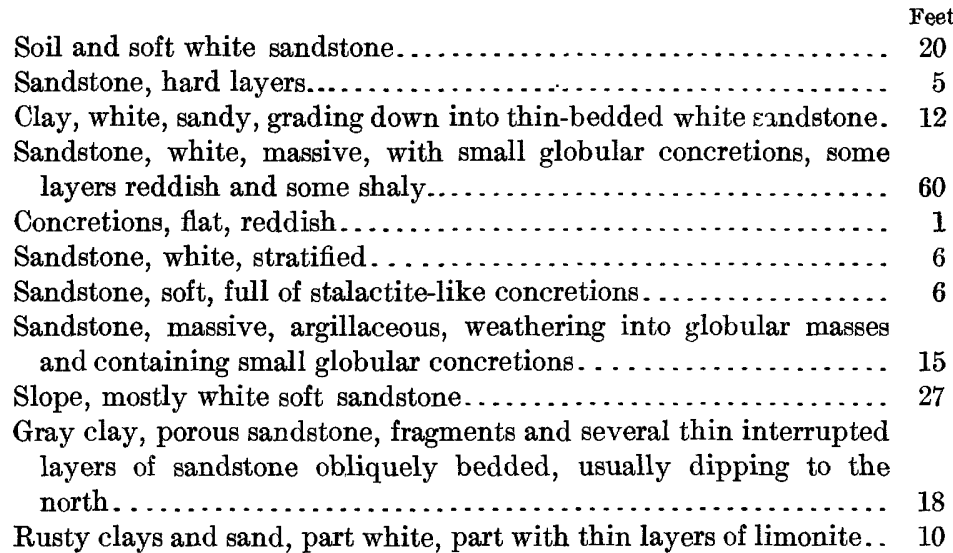

The beds in this section include both Arikaree (?) and White River, but the line between them was not indicated. In another section a few miles farther north the Arikaree beds at the top are 100 to 110 feet thick. They consist of white sandstones, with a $2 \frac{1}{2}$-foot bed of white chalky clay 30 feet above its bottom. Next below are clays of the White River formation, about 75 feet thick, containing a 12-foot bed of pure white sand 6 to 10 feet below the top. The top clay, which is of gray color, contains pieces of yellow flint, with casts of stems. The lower clays, 50 to 60 feet thick, are cream colored.

Castle Rock is capped by 110 feet of Tertiary deposits lying on Cretaceous clays. At the base are 30 feet of mostly fine, white, sandy, massive clay, merging downward into 5 feet of grayish-green sandy clay. The upper 75 feet is sandstone, mostly soft, but partly quartzitic, largely massive, but in places thin bedded and with a few pebbly layers. In some respects it resembles portions of the White River group of the Big Badlands, but at least its upper member may be an outlier of the Arikaree (?). No bones were found to throw light on this question.

\section{GEOLOGY OF EASTERN SOUTH DAKOTA. $a$}

\section{GENERAL STRUCTURE.}

The greater part of eastern South Dakota is heavily covered by glacial drift and outcrops of the underlying formations are rare. Fortunately, however, there are numerous deep wells, and from the

$a$ The geology of part of this region is described in detail by J. E. Todd, in the Olivet (No. 96), Parker (No. 97), Mitchell (No. 99), Alexandria (No. 100), Huron (No. 113), De Smet (No. 114), and Aberdeen-Redfield (No. 164) folios: Geologic Atlas U. S., U. S. Geol. Survey, 1903-1909. 


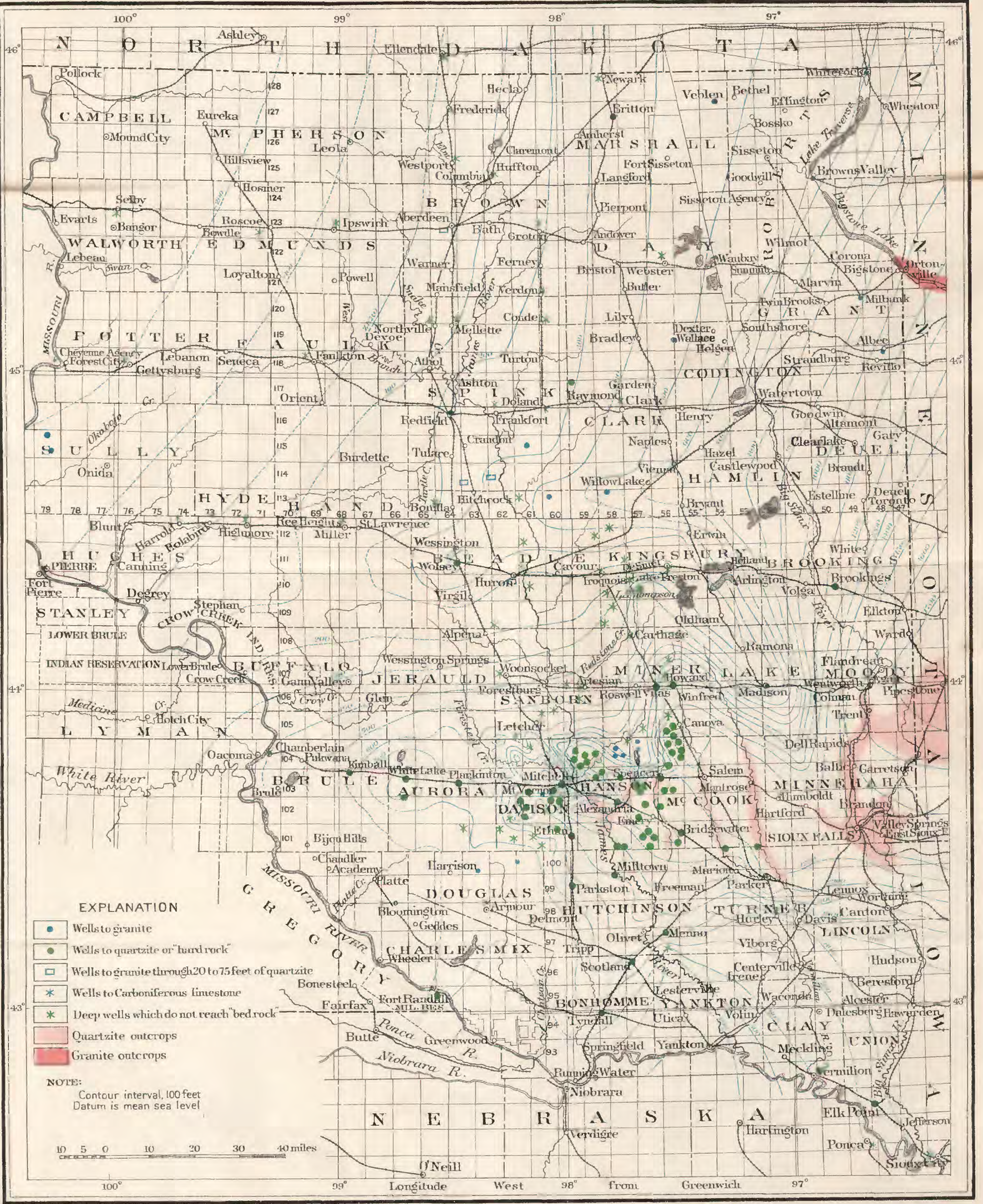

MAP SHOWING CONTOUR AND ALTITUDE OF “BED-ROCK”' SURFACE IN A PORTION OF SOUTH DAKOTA 
records of these it has been possible to ascertain some of the broader features of structure and stratigraphy. Missouri River has cut a deep valley, which affords extensive exposures of the older formations, but the prominent feature for many miles in this valley is a long succession of high banks of Pierre shale. Below the great bend Niobrara chalk exposures begin, and they continue in the lower slopes as far as the mouth of James River. At this place the Benton group appears, and the Dakota sandstone finally outcrops in the extreme southeast corner of the State, near Sioux City, Iowa.

In the outcrops the rocks appear to lie horizontally, but when the relations are studied it is found that there are low dips in various directions. The principal feature is a general rise to the southeast, which, together with the diminishing height of the land, brings to view in that direction the lower formations in succession. There is also a low anticline with its axis extending westward through Mitchell toward Chamberlain, which brings the Niobrara and Benton formations and the Sioux quartzite to the surface over an area of considerable extent in the James River valley. This uplift is coincident with an old ridge of Sioux quartzite which was a shore during the deposition of the Dakota sandstone and, to a-less extent, during Benton time, but apparently was almost if not entirely covered by the Niobrara waters. It was an outlying ridge completely separated from the main shore of granites and gneisses which rise in the Minnesota Valley and toward the northeast.

\section{ARCHEAN AND ALGONKIAN ROCKS.}

The pre-Cambrian crystalline rocks which underlie the Central Plains rise rapidly in the eastern part of South Dakota and finally reach the surface. One area of outcrop extends from the James River valley near Mitchell eastward to the vicinity of Pipestone, its appearance being due mainly to an anticlinal uplift; another is in the Minnesota Valley, where the rocks rise on the slope of the great uplift of the Minnesota area. The configuration of the "bed-rock" surface, as it is termed in eastern South Dakota, is shown in Plate X by contour lines determined partly by outcrops, but mainly from numerous wells which have either reached older rocks or failed to reach them, and thus, in a measure, have delimited their depth.

In addition to the general gradual rise of the "bed-rock" surface to the east, there is a conspicuously high underground ridge or promontory, which extends through Salem and Mitchell toward Chamberlain. This ridge, so buried beneath later sediments that it has no effect on the present topography, has steep slopes several hundred feet high, and would have considerable topographic prominence if the surrounding clays and sandstones were removed. The structure of the younger formations abutting against this underground ridge 
indicates that although it is due partly to anticlinal uplift it was also a ridge of considerable height at the time of the deposition of the Dakota sandstone. The rock of this ridge, known as the Sioux quartzite throughout the area, outcrops extensively along Big Sioux River near Sioux Falls and at other points to the west and the northeast. This quartzite consists mainly of rounded or subangular sand grains cemented by silica and to a greater or less extent built into quartz crystals. It is usually very compact and intensely hard, so that steel of high temper is generally required for drilling it, though some portions are locally much softer. The predominating color is pale pink, but some of it is gray or buff. The bedding varies from slabby to massive. The thickness of the formation is not known, but a well at Sioux Falls 575 feet deep and one at Mitchell 225 feet deep were in typical quartzite throughout. In Hanson County the quartzite ridge rises steeply about 400 feet above an underground plain or valley, whose floor several of the wells have reached and found to be of granite, an occurrence which probably indicates that the present thickness of the quartzite rising to the south is less than 400 feet. As the surface of the quartzite was exposed to extensive erosion, especially during Pleistocene time, as shown by its being deeply scarred by glacial scratches, the original thickness doubtless was greater than it is at present.

To the northeast, in the vicinity of Pipestone, the Sioux quartzite is overlain by or merges into a very compact red clay known as catlinite, or pipestone, a material which has been long employed by the Indians for the manufacture of.pipes and other articles. A few impressions resembling Cambrian fossils were reported from these deposits by N. H. Winchell, but it is believed that the Sioux quartzite as a whole is Algonkian, from its similarity to quartzites farther northeast which are known to underlie Cambrian rocks.

The Sioux quartzite is penetrated by dikes in the, vicinity of The Dells, near Garretson, Minn., and an igneous mass has been found in well drillings in the southwest corner of Minnesota, and possibly also in sec. 25, T. 104 N., R. 58 E., in South Dakota. Outcrops of the Sioux quartzite occupy a considerable area at Sioux Falls and vicinity, and it rises in extensive and very picturesque walls, in places 50 feet high, in The Dells and on Split Rock Creek. The vertical cleavage which the rock presents in these two localities is a characteristic feature and is the principal factor in the palisadal structure that it exhibits. To the west the rock outcrops in most of the deeper valleys between Sioux Falls and Mitchell, notably on Vermilion River southeast of Parker, along East Fork of Vermilion River below Montrose, on West Fork of Vermilion River near Salem, on Black Earth Creek south of Salem, on Wolf Creek near Spencer and near Bridgewater, on Pierre Creek northeast and southeast of 
Alexandria, on Johnson Creek and its branches north and east of Fulton, on Rock Creek northwest of Fulton, on James River west of Alexandria, at Rockport, and on Enemy Creek near its mouth.

Beyond the area of outcrop the quartzite has been reported from numerous wells of moderate depth in Minnehaha, Moody, Turner, Lincoln, McCook, Hanson, Hutchinson, and adjoining counties. It has been reported in deep wells in Aurora and Beadle counties, and at Scotland and Tyndall, in Bonhomme County.

The records of borings which are claimed to have reached bed rock do not always indicate the nature of the material, some of the drillers reporting "hard rock" or "very hard rock," which gives no clue to its nature. In a few wells samples have been obtained and submitted to persons qualified to determine their nature, but more commonly the record is based only on the judgment of the well drillers. Ordinarily these persons have been able to recognize the typical Sioux quartzite without much doubt, but their judgment as to other rocks is open to considerable question. It is asserted also that in several instances rocks collected on the prairie have been placed in the wells to be afterward churned up by the boring machine, either by some foolish person for mischief, or by the driller for the purpose of giving the impression that he had reached "bed rock" and could abandon further boring. In the following table are given all the data so far obtained regarding the occurrence of "bed rock" in the borings in eastern South Dakota and in the immediately adjoining portions of the adjacent States. This list does not include the many shallow wells which have reached the Sioux quartzite where it is near the surface in eastern Hanson County, central McCook County, and the counties along the eastern boundary of the State.

Wells bored to or into bed rock in South Dakota and parts of adjacent States.

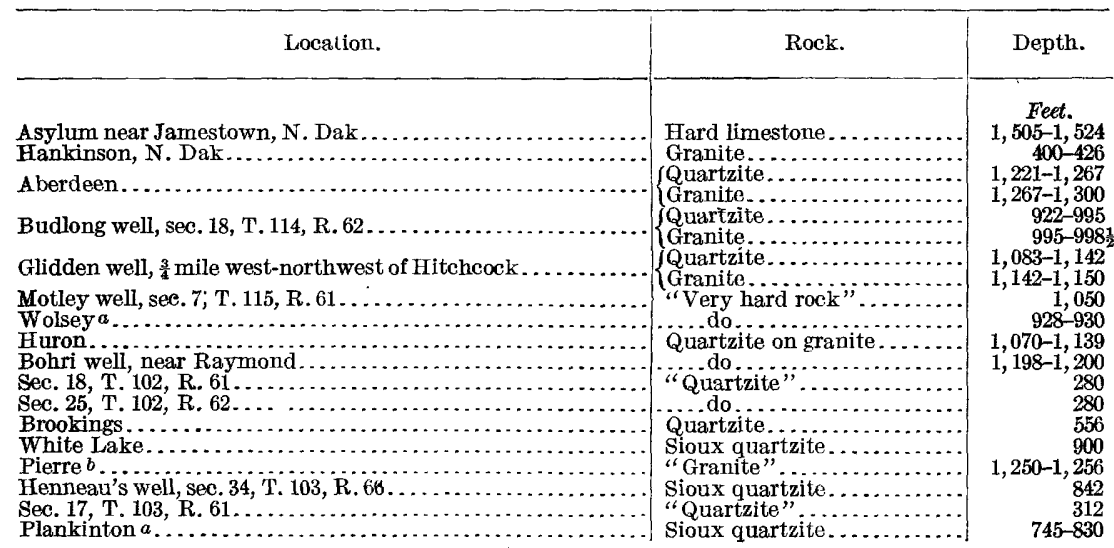

$a$ Nettleton, E. S., Artesian and underflow investigation: Rept. to Sec. Agr., pt. 2, 1892.

$b$ Another well near by found no "bed rock" to a depth of 1,537 feet. 
Wells bored to or into bed rock in South Dakota and parts of adjacent States-Continued.

\begin{tabular}{|c|}
\hline Location. \\
\hline 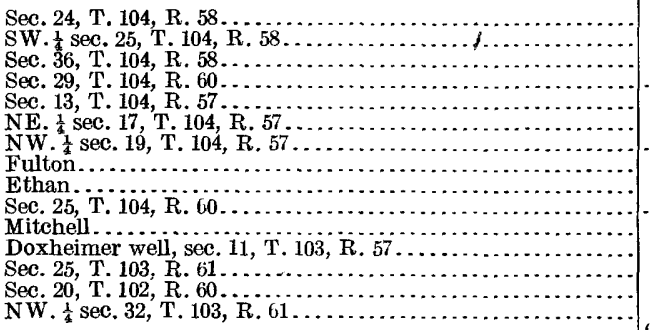 \\
\hline
\end{tabular}

Sec. 29 (?), T. 104, R. 59 .

Elm Springs.

Spencer

10 miles southeast of Salem

West Point region

Humboldt region.

Sioux Falls.

County well, sec. is, T. 100, R. 62

County well, sec. 26, T. 100, R. 64 .

7 miles north of Parker.

Parkston.

Do.

Menno

Well in center of Turner County

Secs. 28 and 23 , T. 110, R. 57

Redfield, asylum

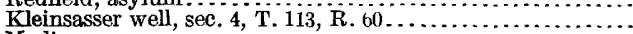
Madison

Wallace.

NW. $\frac{1}{4}$ see. $4, T .113$, R. 58

7 miles southeast of Canastota.

Fort Randall $a$.

Scotland $a$

Tyndall $a$

Yankton.

5 miles north of Alcester

Veblen, Marshall County

Vermilion, University well

Brition.

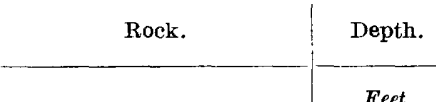

Granite............... Feet.

Diabase................. $\quad 506$

Quartzite............... $\quad 480$

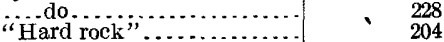

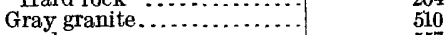

....do ...................... $\quad 557$

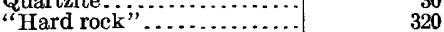

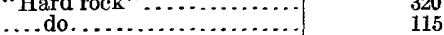

Quartzite...................... $540-765$

"Jasper" ................... $\quad 153$

Dark-gray granite...........

"Quartzite"............... 195

$\begin{array}{lr}\text { Quartzite. } & 288 \\ \text { (Quartzite with sandstone } & 40\end{array}$

and water below.

In one well hard rock....... $\quad 490-496$

Quartzite................. $\quad 100$

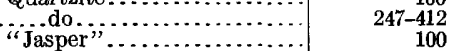

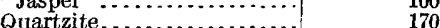

Sioux quartzite............. $\quad 220-247$

Quartzite................. $\quad 300$

140-153

$0-575$

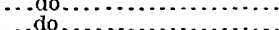

Granite.

Hard rock, "granite"....... $\quad 1,025$

Quartzite................. $\quad 140$

Sioux quartzite............. $\quad 510-522$

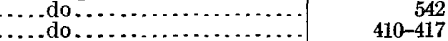

$510-513$

"Very hard rock" ......... $\left\{\begin{array}{l}510-513 \\ \text { or } \\ 556-559 \\ 1,056\end{array}\right.$

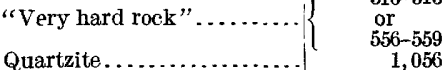

Granite.......................... $1,080-1,090$

Red granite.................. $\quad 940-955$

Black, schistose hornblendic $\quad 1,300$

rock.

Granite.

... do.....................

Quartzite.

"Hard rock" ${ }^{\prime}$...............

Quartzite.

“Granite

"Granite"

"Hard roek" $; \ldots \ldots \ldots \ldots \ldots$

Granite.

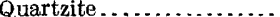

Red and gray granite.

"Very hard rock" ......

"Hard rock" ..do..

Granite.

Do.

Milbank $b$

Granite.

do....

Grado.

"Granite (?)

Granite.

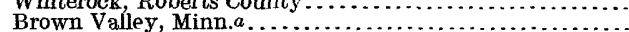

Canby, Minn.

Moorhead, Minn.c......

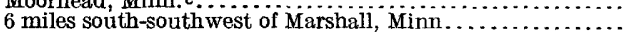

Ponca, Nebr.a.

Sandy shale and green clay.

Limestone.

Limestone, chalky at top...

Sand, marl, etc...........

Sioux City, Iowa $d$

Limestone and sandstone.

Quartzite (?)

Granite or gneiss.

Granite (?) .................

NE. $\frac{1}{4}$ sec. $28, T .115, R, 79$

1,380

990

140

$576-610$

535-587

735

480
460

860

$1,074-1,075$

$303^{2}$

367

280-303

168

500
$425-465$

400

$360-1,750$

505-5051

420-455

455-498

335-1, 255

$1,255-1,320$

$1,510-1,525$

$1,525-2,071$

$1,780-1,781$

$1,645-1,646$

$a$ Nettleton, E. S., Artesian and underflow investigation: Rept. to Sec. Agr., pt. 2, 1892

$b$ Winchell, N. H., Notes on some deep wells in Minnesota: Fourteenth Rept. Geol. and Nat. Hist. Survey Minnesota, 1888 , p. 14.

c Winchell, N. H., Natural gas in Minnesota: Bull. Nat. Hist. Survey Minnesota No. 5, pp. $27-31$.

d Todd, J. E., Notes on geology of north-northwest Iowa: Proc. Iowa Acad. Sci., 1891. 
These data, in the main, satisfactorily agree with one another and with the general structure. A few indicate rather unexpected details of configuration of the "bed-rock" surface, but on the whole the apparent distribution of the various rocks and the underground contour of the surface on which the water-bearing Dakota sandstone lies are everywhere in reasonable accord. (See Pl.X.) The general form of all the larger features is indicated, at least approximately, by the record of more than one well.

It is undoubtedly the case that more complete data, or a different interpretation of certain well records, might suggest modification of the contours shown, but such modification would probably be in respect to minor details.

The high quartzite ridge extending underground nearly due east and west through Minnehaha, McCook, and Hanson counties, and prolonged with diminished height to White Lake and beyond, is perhaps the most noteworthy feature shown. Its extent and altitude are deduced very obviously from the records of a large number of borings which are fully in accord in nearly every respect. In several wells the Sioux quartzite, with its unmistakable texture and pink color, was penetrated for a number of feet, and between James River and Enemy Creek, near Mitchell and the Minnesota line, are numerous exposures of the rock in the depressions which cross this buried ridge. As previously stated, at Sioux Falls the typical Sioux quartzite was penetrated by a boring to a depth of 575 feet without reaching its base, and at a number of other points as far west as White Lake it has been penetrated to a considerable depth.

A sample of the material penetrated between 512 and 518 feet, from the boring in sec. 24 , T. 104 N., R. $58 \mathrm{E}$., was found on examination to be a dark granite. This was at the base of the north side of the buried quartzite ridge above referred to, and would indicate that the quartzite is underlain by granite. In two county wells in the northern part of Douglas County granite was reported in a similar position on the opposite side of the quartzite ridge, but the identity of the rock is open to some question. The deep valley in the bed-rock surface lying north of the buried quartzite ridge is indicated by the fact that the Huron, Iroquois, Woonsocket, and Madison wells did not reach bed rock.

At Madison a black schistose hornblendic rock was found at a depth of 1,300 feet, or 372 feet above sea level. It is on this evidence that the deep bed-rock valley is shown to extend southward under Lake County. The evidence of the line of borings from Brookings to Wolsey indicates some interesting features of underground topography in the bed-rock surface. None of the borings give definite evidence as to the nature of the rock penetrated. In the De Smet well, it was at one time supposed that the quartzite had been reached 
in a hard rock at a depth of 1,456 feet; but at 1,470 feet the drill passed out into soft sandstone, presumably of Dakota age, which carried water. As no bed rock was reported in the 800-foot boring at Arlington, the bed-rock surface evidently slopes down gradually from 1,160 feet above sea level at Brookings to less than 200 feet above sea level at Iroquois, where no bed rock was reached. At Huron the occurrence of bed rock at slightly less than 200 feet above sea level indicates the position of the deeper portion of the basin, for the bedrock surface appears to rise steeply toward Wolsey. Nettleton is authority for the reported occurrence of the rock in the Wolsey well at an altitude of 420 feet above sea level, as he states in his "log" of this well that at 928 feet the boring entered very hard rock, into which it penetrated 2 feet. This would indicate the presence of a ridge terminated by steep slopes, on the west as shown by the deep wells around Miller and St. Lawrence, on the south, as indicated by wells north of Wessington Springs, and on the east, as indicated by the deep wells southwest and southeast of Huron, none of which reported bed rock.

The prolongation of this ridge to the north is fully borne out by the record of three wells north and northeast of Hitchcock. In two of these, the Budlong and Glidden wells, the quartzite was bored through and the underlying granite entered for a short distance. In the third well, at the ranch of Mr. Moxley, bed rock is reported at an altitude of 250 feet above sea level, but it was not penetrated and its nature was not stated. Borings from the Glidden and Budlong wells were examined, and there is no doubt as to the nature of both the quartzite and the granite, as indicated in the logs and stated in the table on page 35. The middle portion of the quartzite in the Budlong boring was not so distinctive in character as the upper and lower beds, for it appears to be of a somewhat softer material. The borings from the granite contained unmistakable feldspar fragments of jagged outline and in very fresh condition, together with some scales of mica and a large amount of quartz, mainly showing sharp edges. Some of the quartz grains were rounded, possibly by water action, but just as likely by the churning of the drill. It is also possible that some or all of these rounded grains were of sedimentary origin, but if so they were undoubtedly derived from the overlying quartzite. It should be borne in mind in making a judgment on borings of this character that more or less of the overlying material is detached by the drill in its descent and ascent below the bottom of the casing. As the process of drilling in so hard a rock as granite is relatively slow, there is much more chance for the admixture of material detached from above than in rapid boring through soft beds.

The precise course of this ridge, which passes south of Hitchcock and extends probably to Wolsey, and its relations to the adjacent 
slopes of the bed-rock floor eastward are not definitely known, but the presence of bed rock in wells in T. 113 N., R. 58 and 60 E., the experience of the Bohri well, near Raymond, and the a,bsence of bed rock in the 1,200-foot boring at Clark indicate approximately the features shown in Plate X. The Doland, Redfield, Ashton, Turton, Conde, Mellette, and Northville deep borings, which did not reach bed rock, indicate that it is not prolonged toward the north. The Bohri well penetrated supposed bed rock for 2 feet, but no report was given as to the nature of the rock except that it was very hard. The deepest boring at Aberdeen found the water-bearing beds and some underlying shales and sandstones underlain by 46 feet of quartzite lying on granite which was penetrated for 33 feet. This relation of the quartzite to the granite is in accord with the experience of the wells near Hitchcock. The position of bed rock in the Aberdeen well, in relation to that in the Hitchcock region, indicates a relatively gentle slope from the top of the Wolsey ridge to Aberdeen. To the east of Aberdeen there is but little evidence as to the nature and rate of the bed-rock slope, but the relations of the Groton, Andover, and other wells which did not reach it indicate that its rise is very gradual. This is further shown by the altitude of bed rock in wells at Britton and Veblen, to the northeast.

The boring at Milbank, in which the granite was penetrated for some distance, the surface outcrops of the formation in the Minnesota Valley below Ortonville, and the presence of granite at a depth of 168 feet at Albee all bear out the idea of regular slope. The Brown Valley well appears to have reached the granite on this slope and to have penetrated it for a short distance. The material is not stated to be granite by Winchell, but as part of the borings were "greenish micaceous kaolinic clay or shale," and "white, opaque, and wholly unwaterworn angular quartz grains," it seems exceedingly probable that the material represented granite in at least the lower 40 feet of the boring.

It is reported that the quartzite was penetrated in a number of wells in the southeast corner of South Dakota, including those at Parkston, Scotland, Tyndall, and Menno, and a well southwest of Parker. At Yankton the granite was reached at so low an altitude that a valley in the bed-rock surface is indicated. At Fort Randall the nature of the hard rock, which according to Nettleton was penetrated for 34 feet, is not stated, but presumably it was quartzite. The nature of the hard rock found in two borings at Elk Point is not known. The Ponca and Sioux City borings found Carboniferous limestone underlying the Dakota water-bearing beds, possibly with a thin intervening representative of some intermediate formation. The Sioux City boring passed through a great mass of the limestone, some limestone and sandstone, and 15 feet of a hard brown rock 
which, according to Todd, may be the Sioux quartzite, and then penetrated for nearly 550 feet into hard gray granite. The borings at Parkston and Menno and southwest of Parker indicate that the buried quartzite ridge which is so prominent from the vicinity of Mitchell to Sioux Falls sinks rapidly to the south but at a less slope than to the north, and this slope is further delimited by the experience of borings near Parker and in central-western Turner County. The steep slope in the Canton region is indicated by the relation of the surface outcrops, the rapid increase of thickness of the Dakota and overlying Cretaceous sediments, and the records of one or two borings in the southern part of Lincoln County. To the south of the steep southern front of the buried quartzite ridge there appears to be a relatively gentle slope intersected by two valleys, one of which heads near Menno, as indicated by the failure to reach bed rock in a 747 -foot well and by the relations of the wells in eastern Douglas County. The position of the bed rock at Pierre is uncertain owing to contradictory reports from two wells, one claiming to have penetrated granite at a depth of 1,250 to 1,256 feet, or at an altitude of about 190 feet above sea level, while another boring near by was sunk to a depth of 1,537 feet and found no bed rock.

The irregular contour of the bed-rock surface, as shown in Plate $\mathrm{X}$, is no doubt due partly to subaerial erosion prior to the deposition. of the Dakota sandstone. It has been suggested that the quartzite ridge which extends through Mitchell is a portion of the Dakota sandstone locally lithified, but the evidence of overlap and many other relations appear to indicate that this can not possibly be the case.

\section{PALEOZOIC TO JURASSIC.}

Although it is probable that the Paleozoic rocks extend for some distance eastward from the Black Hills, southward from Manitoba, and northward from Nebraska, they are absent in most of that part of South Dakota lying east of Missouri River. The deeper wells at Aberdeen and Pierre found materials apparently all of Cretaceous age lying directly on the old crystalline rocks. South and east of these localities the same conditions prevail, and on the underground ridge of the Mitchell region even the Dakota sandstone is absent in an area of considerable size. South of this ridge, as far as Yankton and apparently also at Elk Point, numerous wells have found the Dakota sandstone underlain by quartzite and granite without suggestion of intervening rocks. At Ponca, Nebr., however, the Dakota sandstone is underlain by a series of limestones and sandstones which undoubtedly represent the Carboniferous and possibly still older sedimentary rocks, and at Sioux City, Iowa, similar relations were found. These indicate that the Paleozoic rocks, especially the Carboniferous, which 
are so extensively developed in Iowa and Nebraska, extend at least to the southeast corner of South Dakota.

The red beds and marine Jurassic sediments probably do not underlie eastern South Dakota. It is possible, however, that the formation there termed Dakota may include, locally, at the base the Morrison, Lakota, and Fuson formations of the Black Hills and of the Rocky Mountain region. There is, however, no direct evidence on the subject, since the rocks do not outcrop, and it is mentioned here merely as a suggestion.

\section{CRETACEOUS SYSTEM.}

\section{DAKOTA SANDSTONE.}

The Dakota sandstone underlies the greater part of eastern South Dakota, rising to the surface in the extreme southeast corner of the State. The predominant material is soft sandstone, moderately fine grained and porous for the most part, and of light-gray color. Intercalated beds of clay or shale, of greater or less extent, separate the sandstone layers. The sandstone lies directly on crystalline rocksgranite or quartzite-but is absent on the higher part of the underground quartzite ridge in the Mitchell region and to the east. Although it rises in approaching this quartzite ridge, mainly owing to anticlinal uplift, it does not arch over but appears to be terminated by a shore line, beyond which there is an overlap of the Benton.

The configuration of the base of the Dakota sandstone on "bed rock" is represented on Plate X and that of the upper surface on Plate XIV. It will be seen that the contour lines representing the upper surface show considerable difference in slope from that of the bed-rock surface, a difference indicating variations in thickness of the formation. This is an important condition as affecting water resources, but there is a great scarcity of precise data bearing on the subject. The formation thins rapidly on the slopes of the quartzite ridge in the Mitchell area, and apparently also about Kimball and Hitchcock, but in other portions of the region appears to average from 150 to 300 feet in thickness. No two sections show the same succession of beds having any constant thickness. The deepest well at Aberdeen penetrates the formation to the underlying "bed rock," indicating a thickness of 301 feet. In this well the formation lies between 920 and 1,221 feet and presents the following succession:

Section of Dakota sandstone in well at Aberdeen.

Feet.

Dark-gray sandstone, water. . . . . . . . . . . . . . . . . . 15

Brownish and gray sandstone, pebbly in part, some pyrites and shale. 142

Fine gray sandstone.............................. 23

Fine hard brown shaly sandstone........................ 72

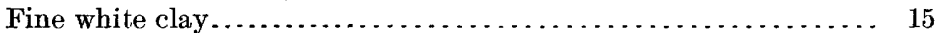

Fine gray sand, no water............................... 34

Quartzite. 
Another report gives 77 feet of clay as constituting the lower part of the 142-foot series and 37 feet of clay as the lower part of the 72-foot series.

In Spink County many of the deep wells penetrate the formation for 40 to 208 feet, traversing thick masses of sandstone with thin bodies of shale. In the Frankfort well the formation lies at 800 to 1,008 feet, with the following succession:

Partial section of Dakota sandstone in well at Frankfort.

Conglomerate, at 800 feet....................... 3

Sandstone..................................... 122

Hard shale.................................... 20

Sandstone..................................... 40

Hard shale...................................... 15

Sandstone......................................... $8+$

The Glidden and Budlong wells, near Hitchcock, penetrate to the granite of an underground ridge of the older rocks, on which the Dakota sandstone thins and changes character somowhat. The succession in the Glidden well is as follows, beginning at the first sandstone below a very thick mass of Benton shales:

Section of Dakota sandstone in Glidden well, threp-fourths mile west-northwest of Hitcheock.

Sandstone, at 881 feet................................. 6

Shale and limy conglomerate........................ 30

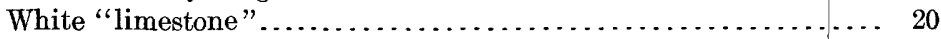

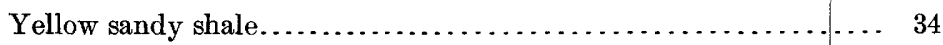

White sand, main flow................................ 3

Shale and limestone.................................. 62

Coarse sand ........................................ 10

White shale and limestone.......................... 38

Quartzite.

This record was furnished by P. J. Stacy, the borer, whose identifcation of materials is exceptionally reliable. The section presents some features unusual for the Dakota sandstone. The Budlong well shows the following section:

Section of Dakota sandstone in Budlong well 5 miles northeast of Hitchcock.

Sandy shale, at 776 feet............................ Feet.

Hard sandstone..................................... 3

Conglomerate...................................... 30

Sandstone, soft...................................... 5

Dark shale...................................... 10

Sandy shale....................................... 12

White shale..................................... 19

Conglomerate......................................... 25

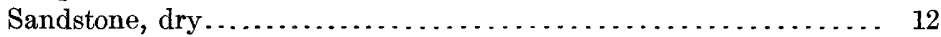

White shale.......................................... 19

Quartzite. 
The Bohri well in Clark County, a short distance northeast of Raymond, entered water-bearing sandstone, supposed to be Dakota, at the depth of 1,005 feet and was bored to "hard rock," presumably quartzite or granite, at 1,200 feet. The following record, if accurate, shows a remarkably thick body of shale below the sandstone:

Section of Dakota (?) sandstone in Bohri well, near Raymond.

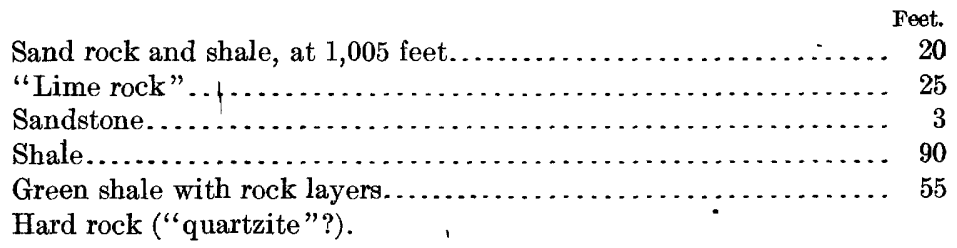

Two wells at Huron, in Beadle County, have bored through the Dakota sandstone into the underlying quartzite and granite. The following is the record in one of them:

Section of Dakota sandstone in city wells Nos. 3 and 4 at Huron.

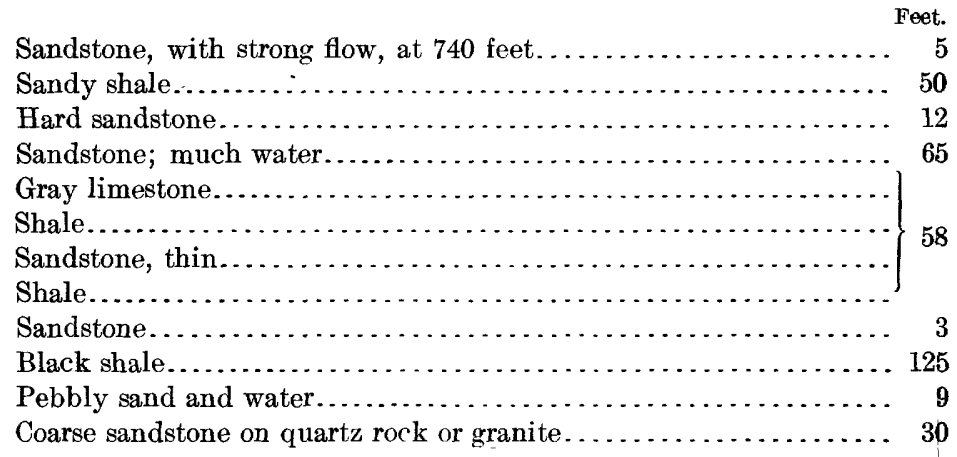

At Wolsey, 12 miles west of Huron, is another well which is claimed to have gone to the base of the Dakota. The following strata are reported:

Section of Dakota sandstone in well at Wolsey.

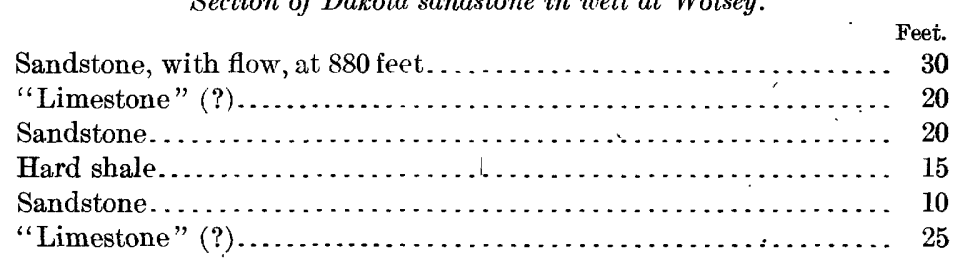

At De Smet, on the highlands 30 miles east of Huron, a deep boring passed through a thick series of sandstone with shale intercalations, probably comprising the greater part of the Dakota and including in its upper beds the lower portion of the Benton. 
Partial section in lower part of boring at De Smet.

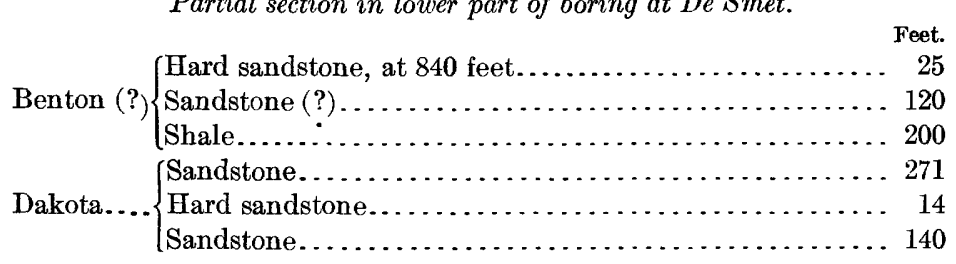

In Sanborn County many wells have reached the Dakota sandstone. The well at the mill in Woonsocket penetrated a solid mass of it from 697 to 775 feet, but had no need to go to the base. A well 2 miles southwest of Letcher reports Dakota sandstone from 400 to 863 feet without reaching the base; the material is mainly clay, including several sandstone layers with flowing water. In the Ashmore well, southwest of Artesian, the Dakota appears to have been entered at a depth of 626 feet; its upper members are 6 feet of sandstone and 67 feet of shale, lying on sandstone, which was penetrated for 2 feet.

In Davison County the thicknesses are variable and diminish rapidly until the formation feathers out in an irregular area on the higher slopes of the underground ridge of Sioux quartzite, south and southwest of Mitchell. At Mitchell the Dakota sandstone appears to extend from a depth of 445 feet to the quartzite at 540 feet, comprising 39 feet of sandstone above and 11 feet of sandstone at the base, separated by 50 feet of shale. In the Smith \& Davison well, 4 miles southwest of Mitchell, in a valley in the buried quartzite ridge, the formation is represented by 40 feet of sandstone and 10 feet of shale resting on quartzite, the top of which lies at a depth of 475 feet. At Ethan only 8 feet of sandstone, which may be Benton, occur on the quartzite. In the Lowrie well, northwest of Ethan, the formation appears to be 92 feet thick, lying on quartzite at a depth of 477 feet and consisting of a top member of sandstone about 30 feet thick and a lower series of shales. The formation thickens rapidly to the west and south, and in the J. K. Johnson well, 3 miles due north of Mount Vernon, the section, which does not reach the underlying bed rock, is as follows:

Partial section of Dakota sandstone north of Mount Vernon.

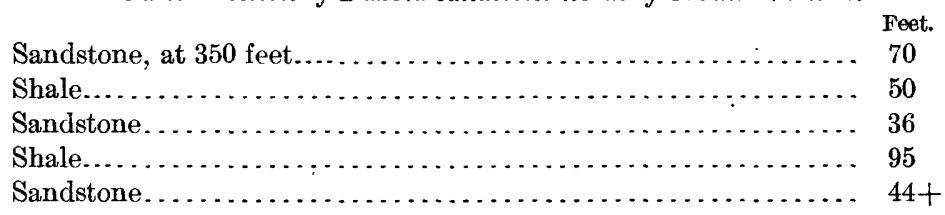

In Aurora County several wells penetrate the formation for 100 feet or more and find alternations of sandstone and shale. The well at Plankinton is said to have reached granite at 756 feet; the overlying Dakota, beginning at a depth of 538 feet, appears to comprise 
218 feet of beds consisting largely of shale, with several thin sandstone bodies. At White Lake beds at a depth of 790 to 850 feet are reported as sandstone and shales lying on supposed granite. The Storla well, in the northeast corner of the county, reports beds apnarently Dakota at a depth of 457 to 760 feet, as follows:

Partial section of Dakota (?) sandstone in Storla well, Aurora County.

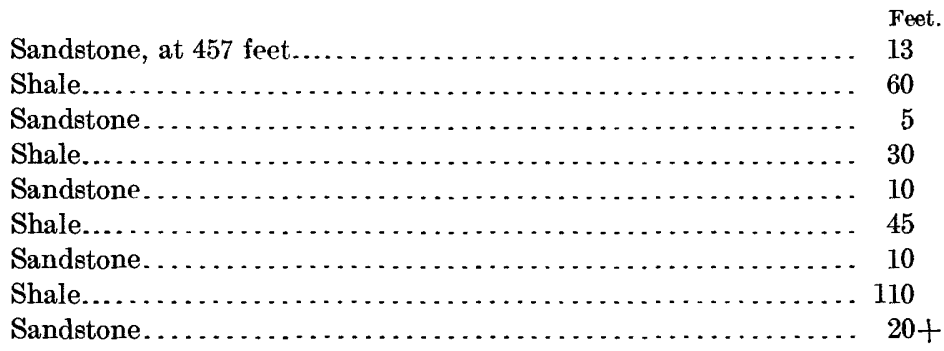

In the Dougan well, 4 miles northeast of the Storla well, there were 23 feet of sandstone on 60 feet of shale, lying on sandstone. In the Bartow well, 3 miles northeast of Plankinton, the following beds are reported:

Partial section of Dakota sandstone in Bartow well, near Plankinton.

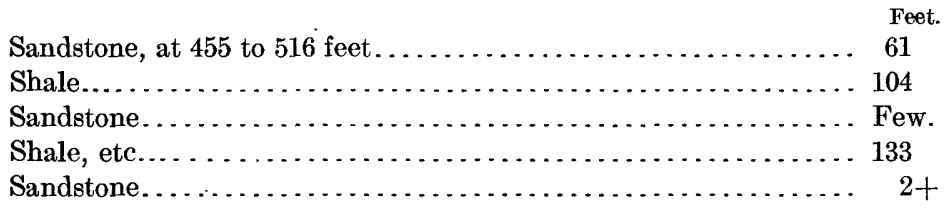

In the Resley well, 4 miles southeast of Plankinton, the section is as follows:

Partial section of Dakota sandstone in Resley well, near Plankinton.

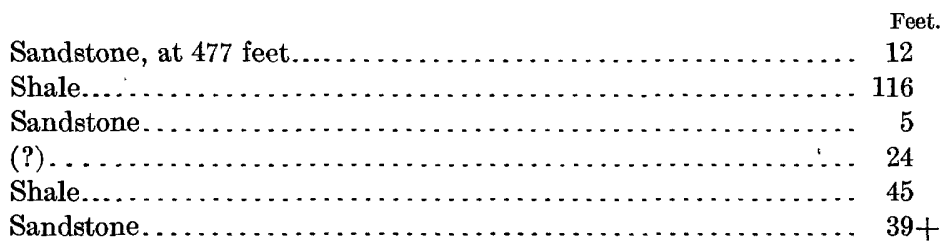

The formation is absent in the central and southern portions of Hanson County, but in its northern and northeastern parts has been penetrated by several deep wells and found to consist of 20 to 53 feet of sandstone lying on granite or quartzite. Apparently it thickens rapidly to the north in the western part of Miner County and in the southeastern part of Sanborn County.

In the northern portion of Hutchinson County, the formation thins out against the Sioux quartzite slopes, but is more than 100 feet thick to the south and the west. At Parkston it appears to have been 
entered at a depth of 460 feet and found to end at "very hard rock," probably quartzite, at 542 feet. Its upper member is a 12-foot bed of sandstone, below which there are alternations of shales and sandy shales. A later boring gives 35 feet of sandstone on 20 feet of shale, lying on the quartzite at a depth of 520 feet. At Tripp 95 feet of sandstone are reported, extending from 729 to 824 feet in depth without reaching the bottom of the formation. In the Morris well, 5 miles north by west of Tripp, the formation was penetrated at 505 to 595 feet without reaching its bottom. It consisted of sandstone with muddy layers below a 7 -foot shale bed, with a very hard sandstone cap 28 feet thick at the top.

But little is known of the thickness or character of the formation in the southwest half of Turner County, which it underlies. A well at Hurley appears to have reached its top at a depth of 400 feet; 3 miles west of that town a well 513 feet deep is reported to have passed through 93 feet of sandstone, with some pyrites and shale, and to have penetrated the underlying quartzite for 3 feet.

In Clay County the Dakota sandstome is reached by many wells, but none of them appear to penetrate it for more than 30 to 40 feet.

In Yankton County several wells have been drilled 150 to 200 feet into the formation. At Yankton one of the later borings has reached the underlying granite at a depth of 898 feet; in the Asylum well, 3 miles to the north, it is reported that the Sioux quartzite was reached at 825 feet. These data indicate a thickness of 415 to nearly 500 feet for the Dakota sandstone. The following record is given of the lower beds in the city deep well:

Section of Dakota sandstone in well at Yankton. ${ }^{a}$

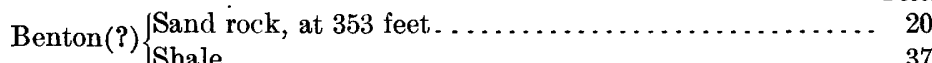

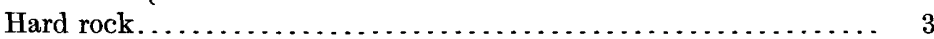

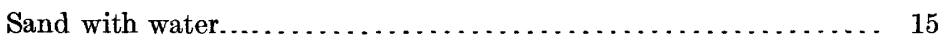

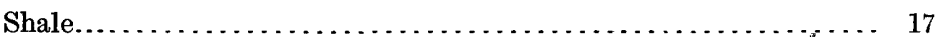

Sand with water....................................... 30

Hard rock . . . . . . . . . . . . . . . . . . . . . . . . . . . 4

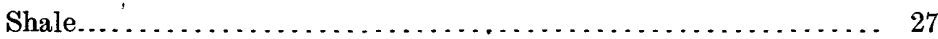

Flint . . . . . . . . . . . . . . . . . . . . . . . . . . . . . 2

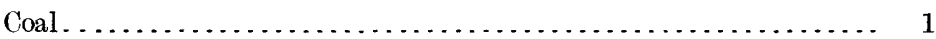

Shale............................................ 26

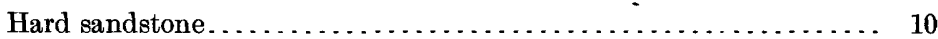

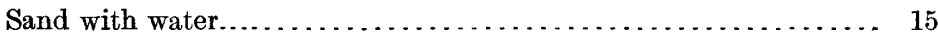

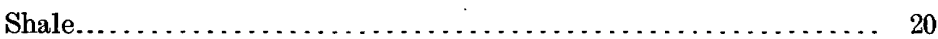

Sandstone...................................... 29

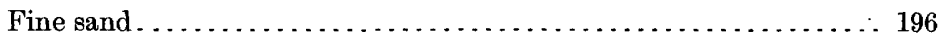

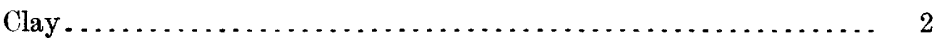

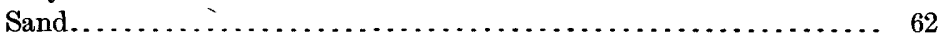

Greenish clay .................................... 7

Tough green rock. 
In Bonhomme County the Dakota sandstone varies considerably in thickness and presents the usual variability in character. At Springfield it appears to have been penetrated from 440 to 592 feet without reaching its bottom, the upper 90 feet consisting of sandstone and shales and the lower 62 feet of a solid mass of very permeable sandstone containing a great volume of water. In the Layson well, on the highlands northwest of Springfield, the formation was entered at a depth of 810 feet and supposed bed rock was found at $1,075 \frac{1}{2}$ feet; the beds consist of an upper member of 230 feet of sandstone with very little water and a lower series of sand, gravel, and sandstone lying on 38 feet of black mud at the base of the formation. The well at Scotland reached a depth of 680 feet, passing about 80 feet into the Sioux quartzite and obtaining only a moderate supply of water from the Dakota sandstone. The following record begins below a thick body of shales and a succession of limestone and shales and thin sandy layers which continues to a depth of 476 feet.

\section{Partial section in well at Scotland.}

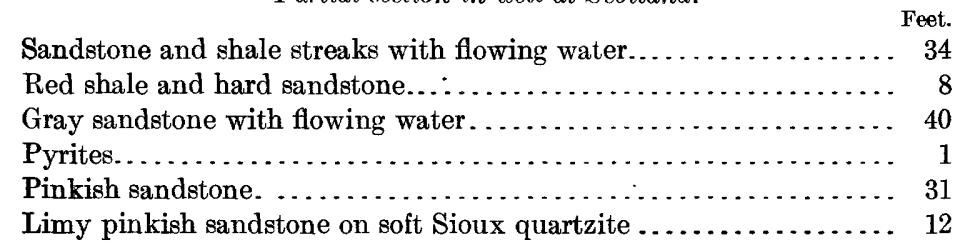

Some of the wells in Charles Mix County have penetrated the Dakota sandstone for greater or less distances without reaching its bottom. The usual irregular alternations of standstones and clays are reported, the sandstones locally thickening to 70 feet, as in the Lake Andes well. In the Hammer well, west of Castalia, a hard rock with pyrites, supposed to be the top of the Dakota, is reported from 725 to 755 feet. Next below are 30 feet of shales and 181 feet of water-bearing sandstone.

As most of the Brule County wells obtain abundant water supplies from the upper part of the Dakota sandstone they do not penetrate it very deeply. At Chamberlain the formation has been explored for over 100 feet; some drillers report it solely as sandstone, but others state that heavy masses of shale separate the sandstone layers. At Kimball sandstone was entered at 900 feet and as the upper beds did not yield as much water as was desired the well was continued to a depth of more than 1,200 feet, all in sandstone.

In Buffalo, Jerauld, Hand, and Hyde counties the Dakota sandstone has been drilled for water, but only its upper beds have been penetrated. In Faulk County many wells pass into the formation for 150 to 200 feet and find sandstone predominating, with shale alternathons in some areas. No well has reached the bottom of the forma- 
tion. At Gettysburg, in Potter County, the formation appears to extend from a depth of 1,780 to 2,130 feet and to be overlain by 310 feet of sandy shales with pyrites. The formation consists of sandstone at the top, 20 feet of sandy shale, 40 feet of sandstone, and 90 feet of alternating sandstones and shales to the bottom of the well.

At Pierre, in Hughes County, two deep wells have recently been completed which throw light on the stratigraphy of the Dakota sandstone, one of them, it is claimed, having reached bed rock. The top of the formation lies 1,130 feet below the surface.

Section of Dakota sandstone in wells at Pierre.

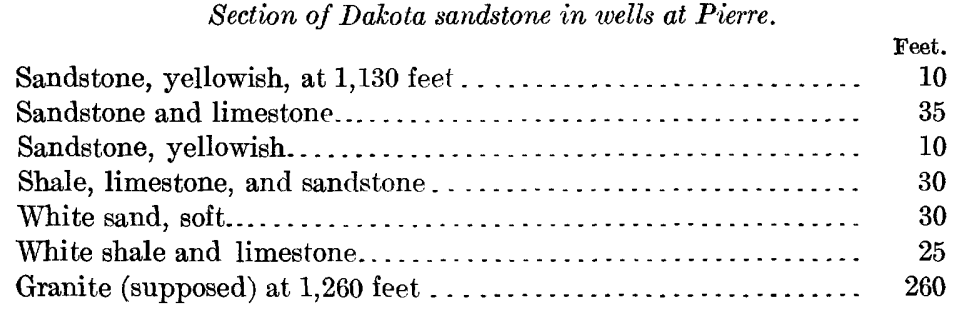

In another well 900 feet west of this one a depth of 1,537 feet was attained without finding granite. Below 1,325 feet the boring went through 125 feet of gray shale and 87 feet of highly carbonaceous shales with some pyrites and lignite. From these two borings a thickness of more than 600 feet is indicated, but the lowermost formation may be older than Dakota.

In the well on the Rosebud Reservation the Dakota sandstone appears to have been entered at a depth of 2,240 feet and the boring continued in it to 2,500 feet, a thickness of 260 feet, without reaching bottom. All the rock was fine-grained sandstone with a few thin layers of shale and some pyrites.

The Dakota sandstone contains abundant plant and molluscan remains in its outcrops along Missouri River near Sioux City, Iowa, and in Nebraska and Kansas. An extensive flora is represented, constituting the typical Dakota flora of Upper Cretaceous age. The Mollusca are fresh-water forms, which occur in considerable variety, but are not very distinctive as to age. According to Todd, Goniobasis, a fresh-water mollusk, was found in considerable numbers at a depth of 785 feet in wells near Esmond. This fossil is typical of the formation in the outcrop region to the south. Todd also reports that plant impressions were found in a well near Hitchcock.

\section{BENTON GROUP.}

Nearly all of eastern South Dakota is underlain by the Carlile, Greenhorn, and Graneros formations, constituting the Benton group, the exceptions being on the higher portions of the underground ridge of Sioux quartzite extending eastward from Hanson County and along 
Minnesota River. The group has a thickness of several hundred feet and consists mainly of dark-colored shales or hard clays, with thin beds of sandstone, parted near its middle by the very characteristic Greenhorn limestone, presenting a succession of beds similar to those in the Black Hills, but greatly decreased in thickness. Over a considerable area a notable bed of water-bearing sandstone occurs at or near the top of the Carlile shale, being either immediately overlain by the Niobrara chalkstone or separated from it by a small amount of black shale.

The Benton group outcrops extensively along the south bank of Missouri River below the mouth of the James River and in the valley of the Big Sioux below Canton. One of its most typical exposures is on the south side of the Missouri, opposite Vermilion, where the thickness is about 250 feet and where there is in the lower medial portion a very characteristic bed of slabby limestone 30 to 40 feet thick-the Greenhorn limestone of the Black Hills and Rocky Mountain regionfilled with the typical fossil, Inoceramus labiatus. The basal beds are dark shales, similar to the Graneros shale of the region farther west, 50 to 90 feet thick. The upper beds are Carlile shale, about 160 feet thick, containing several thin sandstone layers and zones of concretions. The group is also exposed at intervals in the bluffs along the east side of the Big Sioux and southward to Sioux City, Iowa, where its included limestone has been mistaken for the Niobrara, possibly on account of a small amount of chalk that is associated with it.

The group also appears to be near the surface under the drift in the Minnesota Valley, as indicated by the occurrence of Prionotropis woolgari in shallow wells about Milbank. Other outcrops, due to uplift and erosion, appear along James River and some of the tributary valleys in Davison, Hanson, and Hutchinson counties. The most extensive of these exposures are along Twelvemile, Enemy, and Firesteel creeks and on James River in the vicinity of the quartzite. The principal material in these outcrops is a buff or brown massive sandstone, exposed for a thickness of 15 to 20 feet at the greatest. The grain is coarse; there is more or less cross-bedding; and in many places small pebbles are included-all being features very suggestive of the Dakota. Heretofore, in fact, this sandstone has been regarded as a part of the Dakota. In well borings near by, however, it is found that it is underlain by several hundred feet of shales of typical Benton character, in some places containing distinctive marine fossils and underlain by typical Dakota sandstone. It contains some fragments of wood and a few leaves, and undoubtedly is the product of shallow waters, which continued even as late as the beginning of Niobrara time along the shore afforded by the ridge of Sioux quartzite. Shark's teeth are reported from the associated 70214-IRR $227-09-4$ 
shales, also indicating marine conditions. Benton shales, associated with this sandstone, are exposed at a number of points along Enemy, Twelvemile, and Firesteel creeks and James River.

The formations of the Benton group, as shown by the records of the wells, present considerable variation in local character and thickness. Apparently they thicken gradually to the north and the west, being thinnest in the area of outcrop in the southeast corner of the State. In the vicinity of the quartzite ridge, in Davison County and the counties to the east, they appear to thin out and disappear, overlapping the edges of the Dakota sandstone considerably. Probably, also, there are some small outlying areas under the drift on portions of the quartzite ridge.

In the northeastern portion of the State, unfortunately, the Niobrara formation is not clearly recognized, so that the limits of the Benton group can not everywhere be ascertained. In the wells at Aberdeen the group appears to be 400 feet thick, if certain limestones that are given in the records really belong to the Niobrara. On the sarre basis the group is 480 feet thick in the Andover wells. In Spink County the amount is somewhat less, but it appears to be 310 feet in the Cavanaugh well, near Hitchcock, and 380 feet in the Glidden well, measured downward from the bed of sandstone which appears to be the one that characterizes the summit of the Carlile shale in other portions of the region.

In Beadle and Kingsbury counties the thickness of the Benton group appears to vary from 400 to 500 feet, probably increasing to the west, although the limits of the formations are not defined in that region. In eastern Jerauld County the Benton group is 540 feet thick in the Feistner well, 510 feet in the Beug well, and 471 feet in the Schmidt well.

In central and southern Sánborn County, where the group lies nearer the surface, the thicknesses vary greatly, diminishing rapidly toward the south. In Davison County the relations are clearly ascertained by numerous well borings, in which the thicknesses are found to vary mostly from 200 to 300 feet, and the upper sandstone continues to be a characteristic feature. This sandstone thickens and thins locally, ranging from 20 to 85 feet in the southwestern part of the county, and is usually directly overlain by the Niobrara chalkstone, although in portions of the area there is an intervening mass of shale, which locally attains a thickness of 50 feet.

In the northern part of Hanson County, where the formations of . the Benton group vary in thickness from 250 to 300 feet, the upper sandstone is a conspicuous feature. In the vicinity of Ethan, Davison County, the formations are 190 to 200 feet thick, and at Ethan 182 feet thick from the chalk above to a basal sandstone 8 feet thick, which may be Dakota, lying on the quartzite. The stratigraphy 
varies considerably in this region, there being at various horizons thin layers of sandstone, some of which yield a flow of water under moderate pressure.

In Miner County the formations of the Benton group have been penetrated at Carthage, where the chalk was found to be underlain by 30 feet of the upper sandstone of the Carlile, and this by 250 feet of shale, with considerable pyrite in layers, lying on typical Dakota sandstone.

In Hutchinson County the formations of the Benton group present their characteristic features, but thin considerably on the slopes of the buried quartzite ridge in the northern portion of the county. At Tripp a thickness of 400 feet is reported, comprising 100 feet of sandstone immediately underlying the chalk; at Scotland a thickness of 285 feet, with 25 feet of the top sandstone; and at Vodnany a thickness of 305 feet, with the top sandstone very thin. In Turner County the formations of the Benton group are 265 feet thick in two wells near Hurley, consisting entirely of dark shale. In Aurora County they average about 300 feet thick and usually have from 20 to 70 feet of sandstone at the summit, immediately overlain by the Niobrara chalkstone. In Charles Mix County the Lake Andes well has the following record in formations of the Benton group:

Section of Benton group in well at Lake Andes, S. Dak.

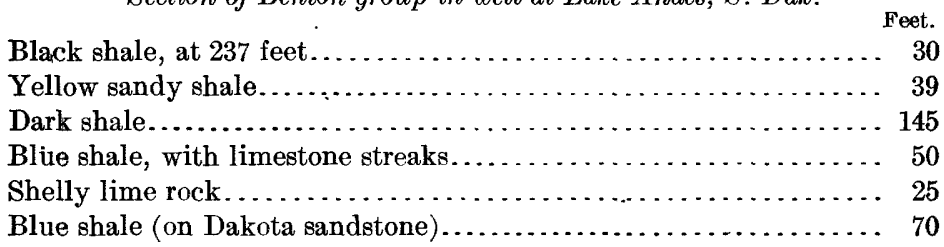

In Brule County the Benton group appears to be from 400 to 500 feet thick and includes sandstone layers at some localities. At the Crow Creek well in Buffalo County it is 350 feet thick, with the usual thin bed of sandstone at the top just below the Niobrara chalk. In Bonhomme County the group varies considerably in thickness, being about 300 feet thick in the Springfield well and 420 feet in the Layson well, on the highlands northwest of Springfield. In Douglas County a thickness of 350 feet is indicated, inclúding a top sandstone of general occurrence underlying the chalk and a great mass of shales below, with a few thin layers of limestone. These thin layers of limestone are mentioned in many of the well records in the southern townships, and probably represent the characteristic Greenhorn limestone horizon. To the south this limestone includes some chalky deposits like those of the Niobrara, but of no great thickness. The top sandstone is from 38 to 60 feet thick in wells about Armour. In the wells about Yankton the group appears to 
be not over 300 feet thick, and apparently it thins considerably toward the east to its outcrop area in Clay County.

In Grant County, as recently ascertained by Todd, the upper portion of the Benton group-the Carlile shale-appears to come to the surface beneath the drift, for in shallow wells about Milbank numerous Prionotropis woolgari occur. The outcrops of sandstone that are reported by the Minnesota Geological Survey in Lyon County and northwest along the eastern slope of the coteau appear to be the upper sandstone of the Carlile formation. One exposure 2 miles northwest of Taunton is a thin-bedded quartzitic rock. According to $\mathrm{H}$. H. Adair the following beds are penetrated in the vicinity of Marshall, Minn.:

\section{Section in wells about Marshall, Minn.}

\begin{tabular}{|c|c|}
\hline r & Feet. \\
\hline Blue clay, with sand streaks. & $0-70$ \\
\hline "Soapstone," light colored... & $70-170$ \\
\hline "Soapstone," dark colored ....................... & $170-270$ \\
\hline "Black sand" or sandy shale, with flow of soft water.. & $270-295$ \\
\hline "Soapstone" & $295-415$ \\
\hline Sandatone with hard moter under hich progaure & $415-425-$ \\
\hline
\end{tabular}

The bed of light-colored rock at 70 to 170 feet may represent the Niobrara chalk rock, and the lowest sandstone appears to be Dakota.

The shale exposures on the east side of Bigstone Lake, a mile from its upper end, have been examined by J. E. Todd, who finds that they are lead-colored shales containing biscuit-shaped concretions, but no fossils. Probably they are of later Carlile age.

At Whiterock, in the northeast corner of Roberts County, about 20 feet of white "chalk" is reported at a depth of 280 to 300 feet, underlain by 200 feet of "soapstone" lying on granite. This white "chalk" probably represents the Greenhorn limestone of the Benton group. In the wells of Browns Valley, Minn., 362 feet of Benton clays, dark at the base, were penetrated to gravels and sands, presumably Dakota, which yield a flow.

In the outcrops of the formations of the Benton group fossils occur in considerable number. Along Missouri and Big Sioux rivers the Greenhorn limestone member contains vast numbers of Inoceramus labiatus, and the associated shales are highly fossiliferous in many places, notably in the bluffs of the Missouri opposite Vermilion. Todd has found many shark's teeth in the exposures of the upper sandstone in Davison County, and reports the occurrence of a fragment of Prionotropis in the dark shale on the east side of James River $1 \frac{1}{2}$ miles north of Elm Spring. Fossils are reported from some of the wells, notably the Ashmore well southwest of Artesian, near the bottom of which Mactra and Fasciolaria were obtained. In the well at Farwell shark's teeth were obtained at a depth of 400 feet. In the well 2 miles north of Woonsocket, at 580 feet below the surface, were 
obtained abundant fragments of fossiliferous limestone, which $\mathrm{T} . \mathrm{W}$ ! Stanton reports to contain a small Nucula with striated surface, which may be the young of $N$. cancellata M. and H., a young Mactra, and numerous Lucinæe of undetermined species. These were found 250 feet below the chalk and 100 feet above the main flow.

\section{NIOBRARA FORMATION.}

The Niobrara formation is a prominent feature in the bluffis of Missouri River above Yankton, especially about the mouth of Niobrara River. It shows almost continuously as far as the great bend, where it passes beneath the Pierre shale at water level. It underlies the drift along the James River valley as far north as Letcher, westward beyond Plankinton, and eastward to Big Sioux River in Hutchinson, Turner, Lincoln, Yankton, Clay, and Union counties, although in the higher part of Turkey Ridge it is probably capped by a small outlying area of Pierre shale. In central Davison, northern Turner, and Lincoln counties it abuts against the quartzite of the underground ridge, on top of which it also lies in detached areas in portions of Hanson, McCook, Minnehaha, and Moody counties. It also appears to extend across the greater part of the northwesternmost counties of Iowa, and along the Iowa-Minnesota state line. The formation is cut through by the Missouri below the mouth of James River, by the Big Sioux below Canton, and by the James from a point north of Mitchell to the center of Hutchinson County. It appears to extend along the east slope of the coteau in the valley of the Minnesota in Grant County, but is there covered by drift.

The formation consists mainly of chalk in the southeastern part of the State, but portions of it grade into shale, which appears to replace the chalk to the north. It is owing to this change in character that very few well borings in the north-central counties report any chalk. The purer material is white or gray when dry, although often dull drab when freshly excavated. It weathers to a bright straw or bright buff color, which is a conspicuous feature in its exposures. It is in greater part massively bedded and is very fine grained and uniform in texture. It is extensively employed for building, being easily quarried and readily shaped by an ax or a saw into suitable building blocks. The chalk consists largely of tests of minute animals, Foraminifera and coccoliths similar to those of the chalk of Europe, mixed with varying amounts of clay and very fine sand. The material was deposited in moderately deep, nearly clear water, without strong currents or other conditions which would bring much admixture of land waste.

In the bluffs along the Missouri, near the mouth of Niobrara River, the locality from which the formation was named, it rises in cliffs 50 to 80 feet high, whose light-buff color is in striking contrast to the 
dark slopes of the Pierre and Benton shales. Exposures are numerous along the river from the mouth of the James nearly to the great bend. On James River and the lower portions of its larger branches the chalkstone is exposed at intervals from Scotland northward to Firesteel Creek in Davison County. There are many exposures on Firesteel Creek northwest of Mitchell and on Enemy and Twelvemile creeks southwest and south of Mitchell. It also appears on Wolf Creek, on Dawson Creek near Scotland, on James River below the mouth of Wolf Creek, and east of Mitchell. It is reported in extensive exposures on Clay Creek, 12 miles northeast of Yankton, on Brule Creek northeast of Vermilion, to the northwest of Canton, and on Split Rock Creek, 2 miles north of Brandon.

Chalky portions of the Greenhorn limestone have been included in or mistaken for the Niobrara by some geologists, an error which has produced considerable confusion in the literature relating to the geology of the eastern portion of this region. The Niobrara formation is characterized by the occurrence of small oysters known as Ostrea congesta, which usually occur in colonies, and locally on the shells of large fossils, constituting an impure limestone. The Greenhorn limestone, as has been explained, is characterized by the occurrence of large numbers of Inoceramus labiatus, a form which occurs sparingly, if at all, in the Niobrara.

The thickness and structural relations of the Niobrara formation have been determined in part by well borings. It is a prominent feature in the wells in Davison County and in the regions to the south, where it consists chiefly of chalkstone; but to the north, as before stated, the chalkstone appears to give place to shale, so that, though undoubtedly existing in the northeastern portion of the State, it is seldom recognized by the well borers. In Yankton County the wells begin in lower beds and soon pass into the underlying Benton deposits. In Bonhomme County the Layton well in the highlands northwest of Springfield appears to have entered the top of the formation at a depth of 90 feet and to have continued in it for 300 feet, including 20 feet of hard limestone at the base. In the town well at Scotland 120 feet of chalk are reported, but in that region some of the top of the formation has been removed by erosion. At Turkey Ridge, in the northeast corner of the county, in one well 215 feet of chalk were reported; at Hurley 100 feet were passed through, and in numerous wells in the central and southern portions of Turner County equal amounts of chalk were recorded.

In Hutchinson County the thickness is considerably diminished as the uplift is approached, but in the western portion of the county, where the Pierre shale overlaps, the full amount remains. In the well at Tripp 275 feet were reported, extending from 25 to 300 feet 
in depth, but probably this amount includes much of the yellow clay of the lower part of the drift. In Douglas County the formation appears to average nearly 100 feet. It is reported to extend from a depth of 190 to 300 feet in a well four miles north of Delmont, consisting of blue shaly chalk above and white chalk below, lying on the sandstone of the Carlile formation. In Charles Mix County the formation is not very definitely reported by any of the well drillers, except in the Hammer well west of Castalia, where it is claimed that chalk extends from 87 to 630 feet in depth, surely a great exaggeration of its true extent. In Brule County the formation appears to average 200 feet in thickness. In Aurora County from 100 to 150 feet are reported, except in the northwestern portion of the county, where the formation has suffered considerable erosion and only from 40 to 60 feet remain. In Davison County nearly the entire surface of the formation has been subjected to erosion, for it lies next below the drift. It is usually entered at 20 to 50 feet below the surface and varies in thickness up to 260 feet, which is reported in wells in the southwest corner of the county. In Hanson County the formation is very thin, and is absent over the greater part of the summit of the buried quartzite ridge.

In Sanborn County the formation varies greatly in thickness. To the southeast it has been partly removed by erosion, and to the north it appears to thin under the Pierre shale. In the McCurdy well at Letcher it is reported to be 175 feet thick, and in the Ryan well near by to be only 70 feet. The latter figure is probably nearer the truth, . for in the Ryan well the limits of the chalk are clearly indicated by the underlying characteristic sandstone of the Carlile formation. In the Woonsocket well the only chalk reported is a layer 24 feet thick from 412 to 436 feet.

In Miner County the chalk appears to be well characterized, having. a thickness of 70 to 120 feet or more, lying under drift to the southwest and under the Pierre shale to the north. At Canova it is reported at a depth of 120 to 150 feet, lying under drift or a small thickness of shale and having a thickness of 50 to 80 feet. In Kingsbury County the only reference to chalk in any of the records is in the Matthews well, 4 miles northeast of Carthage, where it is reported as extending to 493 feet, and in the Welch well, 3 miles northwest of Carthage, where its top is 420 feet deep. In Beadle County chalk is mentioned in a few of the records, but apparently it has given place for the most part to shale which is not distinguished from the adjoining Pierre or Benton. In Spink County some limestone is reported at an average depth of about 450 feet, underlain by sandstone reported to be at the top of the Benton, and this may represent the chalk horizon. "Limestone" reported in the wells at Aberdeen from 515 to 530 feet 
and in those at Andover from 575 to 590 feet may possibly represent the Niobrara. In the Missouri Valley above Chamberlain the chalk is not reported by the well borers, doubtless giving place rapidly to gray shales, as in the northern James River valley region just described.

In the northeast corner of the State chalk rock, which appears to be of Niobrara age, is reported from some wells in southeastern Grant County on slopes above shales yielding Prionocyclus woolgari. The wells in which this rock is found are from 10 to 12 miles south of Milbank.

\section{PIERRE SHALE.}

The Pierre shale extends across the greater part of eastern South Dakota, appearing extensively in the slopes of the Missouri Valley but being mostly covered by drift deposits in the country to the east. Its maximum thickness is probably above the mouth of Cheyenne River, where it is overlain by the Fox Hills sandstone. To the east its surface has been more or less deeply eroded, especially in the area of uplift adjacent to the lower portions of the James and Big Sioux valleys, where it has been entirely removed from a zone of considerable width.

The formation consists almost entirely of dark-gray clay, hardly sufficiently compact to be termed shale and presenting but little variation in its character from top to bottom. It contains scattered concretions, numerous masses of pyrites, thin bodies of sandstone, and some local chalky deposits to the south. Many of the deep wells pass through the formation for several hundred feet, the amount increasing gradually to the north and west of Davison County. In the slopes of the Missouri Valley above the great bend 500 feet of the formation are to be seen, but below the great bend, as the underlying Niobrara chalk rises in the banks, the shale diminishes in thickness and a short distance below the mouth of Niobrara River thins out and disappears. The many variations in its thickness are due mainly to the extensive and irregular erosion suffered by the shale previous to the deposition of the glacial drift by which it is now mostly covered.

It is several hundred feet thick in the ridge lying between James and Missouri rivers, in Charles Mix, Douglas, and Brule counties. At Armour there are probably 170 feet of the formation; 10 miles north of Armour, 300 feet; in the western portion of Aurora County, 350 feet; in Brule County the amount diminishes somewhat, owing to the local uplift; in approaching the uplift in eastern Aurora County the formation thins out entirely; in the highlands of Jerauld County 300 feet are reported. The amount increases on the higher lands, and the increase continues toward the north in the highlands 
between Missouri and James rivers; but owing to the indefiniteness of the well records as to the limits of the Niobrara formation in that direction the precise thickness of the Pierre can not be stated; apparently it is more than 1,000 feet.

In the James River valley about 500 feet are reported in the wells at Aberdeen and Andover and about 400 feet in Spink County; but here also the uncertainty as to the position of the Niobrara formation prevents a clear recognition of the lower limit of the Pierre in the reports of the well borings. In Beadle County the amount is materially less and diminishes to the south until finally the formation thins out in the center of Davison County, on the anticlinal uplift of the Mitchell region.

East of the James River valley, north of this uplift, the formation extends eastward to the margin of the Minnesota Valley, underlying the high coteau, where it has a thickness of several hundred feet. In Kingsbury County it appears to have a thickness of about 100 feet in the highlands on the east, although its limits in the De Smet well are not indicated by the record. It appears to extend southward through Lake County to the quartzite ridge, for it presents considerable thickness in the well at Madison. It also áppears to extend eastward into Minnesota, for Pierre fossils have been found in the western slopes of the Minnesota Valley; and although it has been stated by Todd that probably all these fossils so far reported were found in the glacial drift, yet they have not traveled far. About Taunton, in Lyon County, the fossils are found below the level of the Benton group, and there, as about Milbank, they are inclosed in drift deposits.

Exposures of the formation are exceedingly rare east of the immediate slopes of the Missouri Valley. In the region of thin drift about Ree Heights and to the south the formation outcrops for some distance, and it appears again south of Swan Lake in Potter County, northeast of Gann Valley, and on Turtle Ridge, near Wessington. Springs. Todd states that shallow streams cut into it in western Brown County, northwest of Aberdeen and on Willow Creek and its north branch northwest of Westport; in southeastern Brown County, 5 to 8 miles south of Groton; along James River northeast of Redfield; in northwestern Day County, 2 miles and 4 miles north of Pierpont; and extensively north and south of Groton. Dark shale, probably belonging to the Pierre, is reported in the northeast corner of Yankton County, where it lies on the Niobrara at an altitude of 1,510 feet, and it is believed to extend thence under a considerable portion of Turkey Ridge, beneath the drift. At the cement works 3 miles west of Yankton it caps the Niobrara chalk rock, a relation which it presents in numerous exposures for many miles along the river. 


\section{FOX HILLS SANDSTONE.}

There is no good evidence of the existence of the Fox Hills sandstone east of the Missouri, south and east of Campbell County. It is suggested by Todd that some sand on the high hills north of Forest City and the fine yellow sand along Swan Creek southwest of Bangor may be Fox Hills, and that emnants of this formation may be found in the Faulkton, Bowdle, anf Koto hills. TER IARY DEPOSITS.
Evidence as to the existence of the Tertiary formations in eastern
outh Dakota is meager. On the summits of the Bijou Hills are caps South Dakota is meager. Op the summits of the Bijou Hills are caps
of distinctive green quartzi e of later Tertiary age lying on lightcolored sands and sandy chys. Another area of the quartzite is found on the high ridge due east of Greenwood.

Fossil fish of supposed Ol gocene age have been obtained from the high ridge southwest of Ree Heights, but the extent of the deposit in which they were found has $\mathrm{n} t$ been determined. According to Todd, the high ridge just west of Wessington Springs contains deposits of sandstone supposed to be ooder than the drift and probably of the same age as the quartzite on the Bijou Hills. It shows the same general structure, even carr fing some beds of grit between the finer layers, and lies on lead-color d Pierre clay. Doubtless much of eastern South Dakota was orighally covered by Tertiary deposits, but they were removed by the deep and widespread erosion of early Quaternary time, although on some areas they may remain, mostly covered by the glacial drift. A tooth obtained by Todd from a 175foot well at Trent, Moody C unty, is regarded as Tertiary by W. B. Scott.

\section{QUATERNARY DEPOSITS.}

That portion of South Dal ota lying east of the Missouri is covered in greater part by a thick mantle of Quaternary deposits, mainly of glacial origin. There are several lines of morainal ridges, a nearly continuous sheet of glacial till, extensive glacial-lake deposits, and alluvial accumulations of Pleistocen and of Recent age. These formations have been described in detall by $J$. E. Todd, to whose publications the reader is referred. ${ }^{a}$

a The moraines of the Missouri coteau and their attendant deposits: Bull. U. S. Geol. Survey No. 144, 1896; The moraines of southeastern South Dakota and their attendant deposits: Bull. U. S. Geol. Survey No. 158, 1899; Geology and water resource of a portion of southeastern South Dakota: Water-Supply Paper U. S. Geol. Survey No. 34, 1900; and folios mentioned in footnote on page 32. 


\section{UNDERGROUND WATERS.}

\section{GENERAL CONDITIONS.}

The thick succession of sedimentary formations underlying South Dakota includes porous strata containing large volumes of water. These water-bearing deposits comprise widespread sheets of sandstone or sand ranging from Cambrian to Tertiary in age, the alluvial sands in the bottoms of valleys, and the sands of the sand hills. The sandstones are in many places several hundred feet thick and lie

Black Hills

Eastern

South Dakota

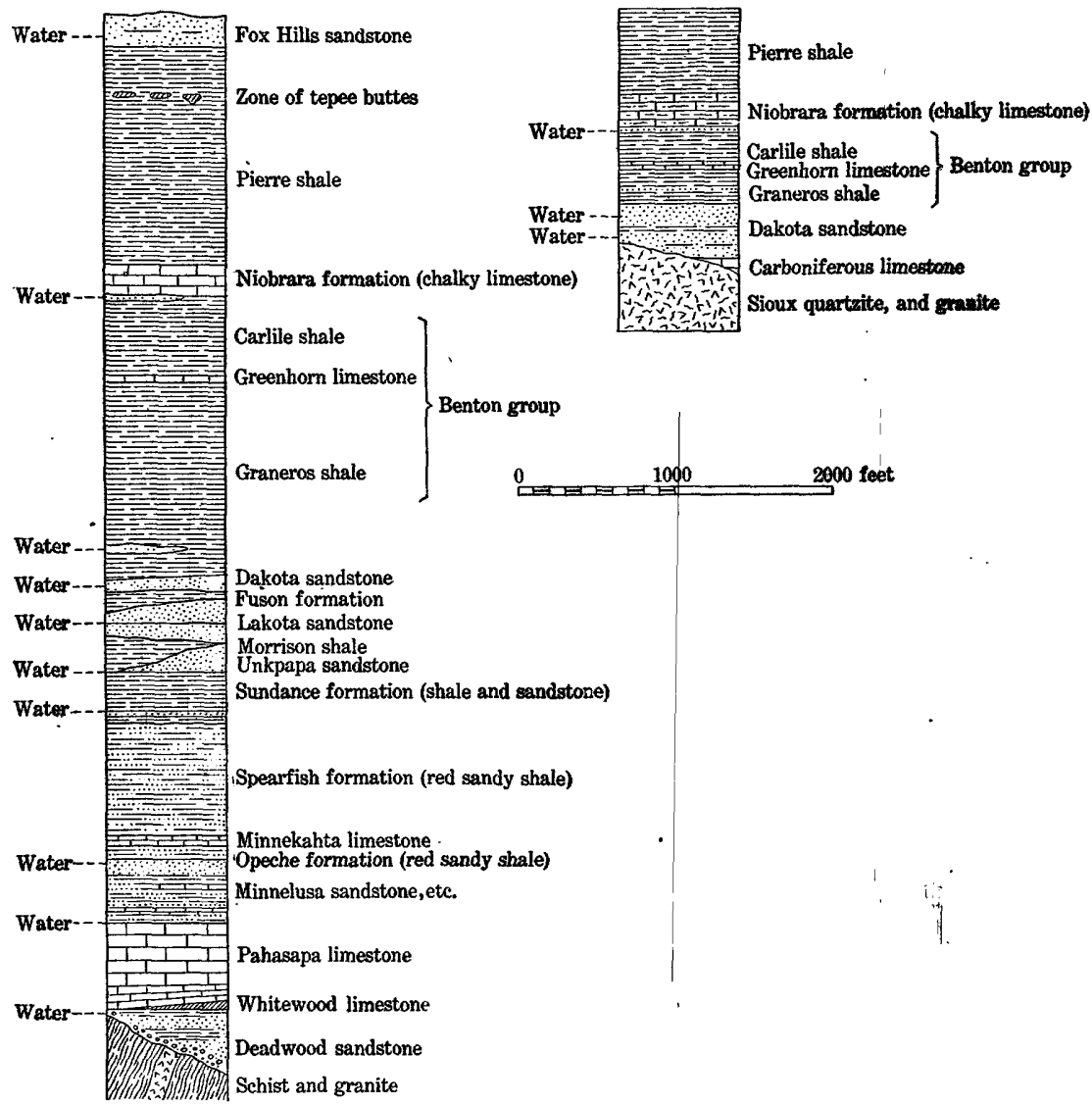

Fre. 1.-Columnar sections showing the water horizons in the Black Hills region and in eastern South Dakota.

between bodies of relatively impermeable shales or limestones, so that they present favorable conditions for artesian waters. To the west they are upturned on the uplift of the Black Hills and outcrop at high altitudes; to the east some of them come to the surface and others thin out. The principal structural relations in the State are shown in the three cross-sections of Plate VI, and the succession of water-bearing horizons is shown in the columnar sections of figure 1. 
Part of the rainfall and stream flow passes into the sandstones in their elevated outcrop zones in the Black Hills and flows eastward through the interstices of the rock in its extension under the lower lands. Some of it finally escapes in springs in the outcrops in eastern South Dakota and Nebraska. In such water-bearing strat as.the Dakota and underlying sandstones, which are overlain by a thick mass of impermeable deposits, the waters are under great pressure, for the intake zone has an altitude of about 4,000 feet and the region of outflow is only 1,000 to 1,200 feet above sea level. The evidence of this pressure, as found in many wells in eastern South Dakota, is conclusive that the water flows underground for many hundreds of miles. Several wells show surface pressures of 175 to 200 pounds to the square inch, the latter indicating a pressure of 780 pounds to the inch at the bottom of the well. Such pressures can be explained only by the hydrostatic influence of a column of water extending to a high altitude on the west. If it were not for the outflow of the water to the

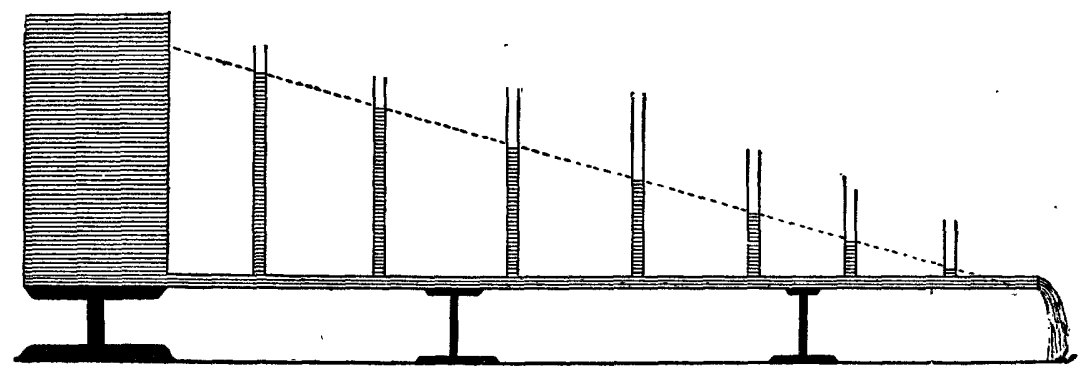

FrG. 2.-Diagram of apparatus for illustrating the declivity of head of liquids flowing from a reservoir. The shaded portions are water.

east and south the initial head which the waters derive from the high lands of the intake zone would continue under the entire region, but owing to this leakage the head is not maintained, and there is a gradual diminution toward. the east known as "hydraulic grade," a slope sustained by the friction of the water in its passage through the strata. Figure 2 shows a simple apparatus which illustrates' the general conditions.

Another factor which undoubtedly somewhat influences the hydraulic grade in the Great Plains region is a certain but unknown amount of general leakage through the so-called impermeable strata, all of which permit the passage of an appreciable proportion of water, especially when under great pressure. The conditions shown in figure 2 are closely similar to those found in the Dakota sandstone, which is the principal water-bearing stratum underlying the Great Plains. From the altitudes of outcrops of this sandstone and pressures observed in many wells the lines in figure 3 and Plate XI have been constructed to indicate the observed and probable head of the 
artesian waters. In areas of flow the pressure in pounds at any point. may be ascertained by subtracting the altitude of the land from

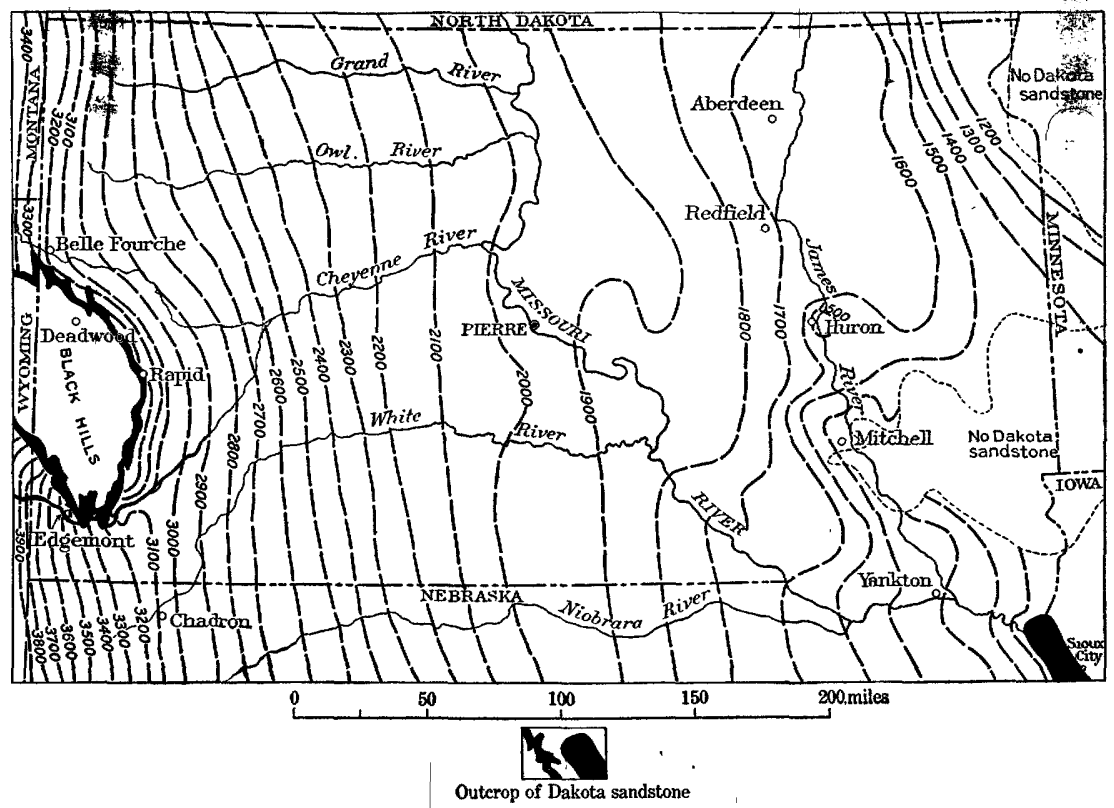

Fig. 3.-Diagram of South Dakota, showing hydraulic gradient by contour lines of head.

the altitude of the head and dividing by 2.3 (the height in feet of a column of water 1 inch square weighing 1 pound). In areas too high for flow the depth to the point to which the water may be

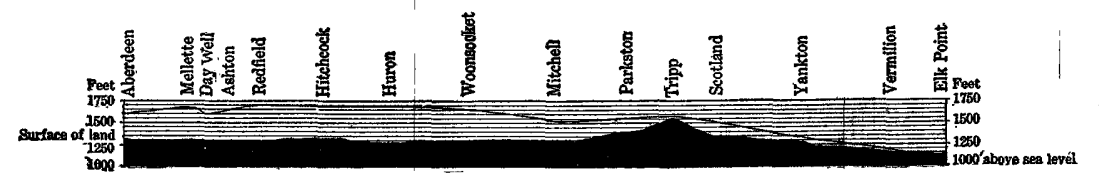

Frg. 4-Profile from north to south down James River valley, showing hydraulic grade. The land profile is shown in solid black; the altitude of the head of the artesian waters by the line.

expected to rise may be found by subtracting the altitude of head from the altitude of the land. Figure 4 shows the hydraulic grade down the James River valley.

WATER HORIZONS.

DAKOTA AND ASSOCIATED SANDSTONES.

The Dakota sandstone is the most widely extended and serviceable water-bearing formation in South Dakota and it is the principal source of artesian flow in the many wells. It consists largely of sandstone, and averages about 300 feet thick. The sandstone is in 
thick sheets separated by deposits of clay or shale. In the Black Hills there are two water-bearing sandstones separated by a shale known as the Fuson formation, which separates the Dakota sandstone above from the Lakota sandstone below. In the Black Hills the Dakota lies on various sediments, as shown in the first section in figure 1. To the east these formations thin out and in the eastern part of the State the Dakota sandstone lies on Sioux quartzite or on granite, except to the extreme southeast, where Carboniferous limestones and other rocks intervene. Apparently the Lakota sandstone and overlying Fuson formation are also absent to the east, but the evidence on this point is not conclusive, at least for the greater part of eastern South Dakota.

The Dakota water horizon is believed to underlie all of the State of South Dakota except in the Black Hills uplift, the high underground ridge of Sioux quartzite extending eastward from Mitchell and a portion of the Minnesota Valley. The areas in which the formation is absent are shown on Plate XI and figure 3. The limits on the east, however, are determined only approximately on the evidence of widely scattered wells and outcrops.

\section{SANDSTONES OF THE BENTON GROUP.}

Although the Benton group consists mostly of shale, it includes beds of sandstone containing more or less water which is the source of supply for some artesian wells in the eastern portion of the State. Many of the wells, also, which obtain their principal supplies from the Dakota sandstone find a first and some of them a second flow in sandstones in the overlying Benton. The principal water-bearing sandstone is a bed which occurs near or at the top of the formation. In some places it immediately underlies the Niobrara chalk; in others it is separated from that formation by black shale which locally attains a thickness of 100 feet. The upper sandstone of the Benton is usually less than 25 feet thick, but ordinarily it is coarse and contains water in moderate amount and under considerable pressure. The sandstone outcrops along Firesteel, Enemy, and Twelvemile creeks and James River in Davison, Hanson, and Hutchinson counties. Its greatest thickness, 85 feet, is attained in the southwestern portion of Davison County. In wells near Armour it varies from 35 to 60 feet thick. The lower sandstones in the Benton group are much less definite in position and occurrence, but they are represented in many of the well records in the James River valley.

\section{MINNELUSA SANDSTONE.}

The Minnelusa sandstone outcrops along the slopes of the Black Hills uplift and undoubtedly it underlies an area of considerable extent 
in the adjoining plains of western South Dakota. The formation consists largely of sandstone (see $\mathrm{Pl}$. IV, $A$ ), some of which is porous and water bearing. The facts that numerous springs emerge from the formation on the higher slopes and that many of the streams crossing the outcrop of the sandstone sink into it in whole or in part, indicate that it has great capacity as a water bearer. Owing to the steep dips. on the sides of the Black Hills uplift the formation is rapidly carried to a depth too great to be reached by ordinary well boring under the plains, but in the Red Valley, where its depth beneath the surface is less than a thousand feet, it may prove to be an important source of water supply. Its capabilities have been tested in the canyon south of Spearfish, where a satisfactory flowing well was obtained from the lower sandstones. The top sandstone usually is coarse grained in the northern hills and probably contains water in considerable amount. It lies about 800 feet below the top of the red beds in the northern Black Hills and about 850 feet below in the southern Black Hills, as shown in the boring at Edgemont. In the boring at Minnekahta the formation yielded no water supply, but in the deep boring at Edgemont it was found to contain considerable water though not under sufficient head to afford a flow. It would appear that in the southern portion of the Black Hills area, and also on the western slope, as indicated by the Cambria well, the formation is too fine grained and too closely cemented by carbonate of lime to yield much water.

\section{FOX HILLS AND OVERLYING SANDSTONES.}

The sandstones in the Fox Hills and overlying formations contain considerable water, but the source of supply is local and the land is too elevated to afford much promise of artesian flow. Possibly flowing wells may be obtained from these sandstones in the Little Missouri Valley and on the lower lands in the upper portion of the valley of Grand River.

\section{DEADWOOD SANDSTONE.}

The Deadwood formation in the Black Hills uplift consists largely of sandstone which undoubtedly contains water. There is only a restricted area, however, in which it will be practicable to reach the formation by wells, for it descends rapidly to great depths along the slope of the uplift. In the Red Valley the top sandstone lies at a depth of about 2,000 feet. The formation has recently been penetrated by a well at Edgemont, and at a depth of 2,920 to 2,980 feet yields a 300 -gallon flow.

\section{CHADRON FORMATION.}

The Chadron formation underlies the badlands area in the southwestern portion of \$outh Dakota and consists mostly of sands and 
soft sandstones which contain considerable water. This water, however, has but little head, for it is of local origin. It yields springs at many localities in the badlands, and water could be obtained by shallow wells; possibly the formation might afford weak flows along the White River valley in the western portion of the Pine Ridge Indian ,Reservation.

\section{DEEP WELLS AND WELL PROSPECTS IN SOUTH DAKOTA.}

\section{INTRODUCTORY STATEMENT.}

As explained in a previous paragraph, there are several sources of underground waters in South Dakota, but the Dakota and associated sandstones furnish the supply for most of the deep artesian wells. Owing to the high elevation of its intake zone along the Black Hills this water is under great pressure and will afford flows in all but the highest lands except in the southeast corner of the State, where the head is lost in approaching the area in which the sandstone reaches the surface. Over a thousand wells have been sunk east of the Missouri, most of them being from 500 to 1,000 feet deep. There is also a group of flowing wells about Belle Fourche, and recently the flow has been struck by wells in the valley of Bad River. The aggregate flow from these wells is estimated to be about $7,000,000$ gallons a day. It is believed by some persons that this great draft is diminishing the available supply of the underground water, but there is no evidence as yet that this is the case except locally in districts where there are numerous wells. Individual wells often diminish in flow and pressure, but usually this is due to leakage or clogging, and new wells in the same vicinity show the same flow and pressure as were found in the older ones. However, it is probable that with increased numbers of wells and long-continued flow the available artesian supply will eventually be materially diminished.

The area in which flows may. be expected from the Dakota and associated sandstones is shown on the map (Pl. XI), which also shows the depths to the sandstone, the location and depths of wells which have been sunk, and the altitude of the head of the water. The last-named item has been determined from the altitude of the outcrop in the Black Hills and the observed pressures in wells. These pressures are converted into head by multiplying the number of pounds to the square inch by 2.3 (the height in feet represented by the pressure of 1 pound) and adding the altitude of the land. This gives the altitude above sea level to which the water would rise in pipes or up the slopes of adjacent higher lands. Lines are drawn on the map for every 100 feet of altitude of head and show a regular down grade from the Black Hills to the southeast corner of the State. Wherever 


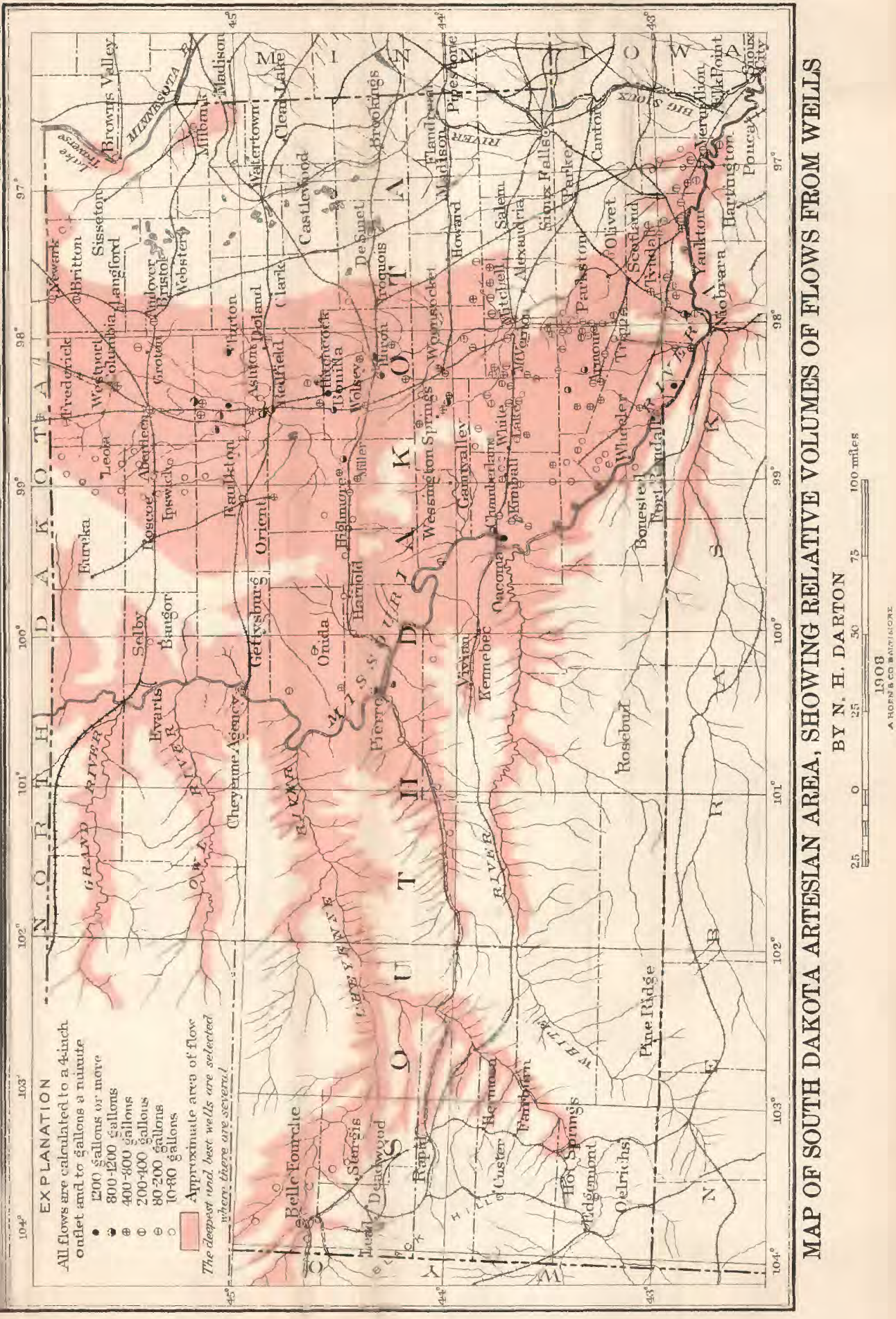



data are lacking lines have been introduced on the assumption that the gradient is regular. Where the altitude of the head is greater than the altitude of the surface the wells will flow, and the flow area represented in Plate XI has been deduced in this manner from the headlines and the topographic contour lines. As the precise gradient of head is not everywhere accurately ascertained, and as some of the topographic data are only approximate, the flow area can be indicated only approximately in some portions of the State. There is, moreover, considerable variation in pressure in the different flows at various depths, and in many wells where the water in the upper sandstones will not have sufficient head to flow, a deeper water will rise to the surface. The data are sufficient to indicate that flows may be expected in a large area in which no wells have yet been sunk in the many valleys of the central portion of the State, in the region north and northwest of Belle Fourche and east of the Black Hills. The depths as shown in Plate XI are deduced from the structure (PI. XIII), thickness, and distribution of the formations and the records of wells. The variations in thickness appear to be regular and most of the structure is evident on the surface, but it is probable that here and there some difference will be found between the true and the predicted depth. Moreover, in many places it is necessary to sink deeply into the water-bearing sandstones before a satisfactory flow is obtained. Relative volumes of flows are shown in Plate XII.

\section{AURORA COUNTY.}

Aurora County lies mainly on the divide between the valleys of James and Missouri rivers. Its surface is largely covered by glacial deposits, which lie on Niobrara chalkstone to the east and on Pierre shale to the north, west, and south. The Dakota sandstone underlies the entire area and contains a large volume of water under pressure sufficient to afford artesian flows, except possibly in the highest hills in the extreme northwest townships and a small area in the southcentral part of the county. The sandstone dips gently to the south in the southern part of the county and to the north in the northern part, arching over a gentle anticline that rises above the underground ridge of Sioux quartzite extending westward from the Alexandria and Mitchell region.

The depths to the sandstone vary from 400 feet near the center of the eastern margin of the county to 550 feet at Plankinton, 800 feet or more in the central, north-central, and southern portions of the county, and somewhat over 1,000 feet in the northwest corner. The Dakota sandstone contains several flows of water, the lowest ones having the largest volume and highest pressure. The volume varies considerably and appears to be less over the underground quartzite ridge which extends east and west in the center of the county. The 
following is a list of the principal wells, with statements as to their depths and other features:

Representative artesian wells in Aurora County.

J. Asmuss, NW. 1 sec. 1, T. 101, R. 64 .

Peter Mathig, SW. 1 sec. 17, T. 101, R. 66.

Anton Hettinger, $N E$. 1 sec. 3 T $101, R$. $66 \ldots . .$.

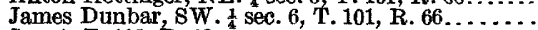

Sec. 1 , T. 102, R. 63 .

Sec. 10 , T: 102 , R. 63

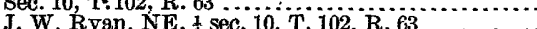

Sec. 11 , T. 102 , R. 63

SE. $\frac{1}{4}$ sec. 17 , Crystal Lake Township

Sam Edelman, NW. $\frac{1}{4}$ sec. 19 , T. 102, R. 64 . Do.

John Scales, SE. $\frac{1}{4}$ sec. 29 , T. 102 , R. 64

Fdelman, sec. 25 , T. 102 , R. 65

George Severance, SW. $\frac{1}{1}$ sec. $7, T .102$, R. 66

Mike Galles, sec. 17, T. 102, R. 66.

Eyer, T. 103, R. 63, 5 miles southeast of

Plankinton.

Evon Raesley, SW. $\frac{1}{3}$ sec. 28, T. 103, R. 63

George Savilie(?), T.103, R. 63

Sam Swenson, sec. 13, T. 103 , R. 63

J. D. Barton, SW. 1 sec. 8, T. 103, R. 63

J. R. Mabbot, sec. 26, T. 103 , R. 63

L. Mabbot, sec. 26 , T. 103, R. 63 .

Leonard Scott, sec. 35, T. 103, R. 63 .

C. R. Cook, sec. 32 , T. 103, R. 63

Sec. 4, T. 103, R. 63

Sec. 8, T. 103 , R. 63 .

Sec. 9, T. 103 , R. 63 .

Sec. 10, T. 103, R. 63

Sec. 11, T. 103, R. 63

Sec. 12, T. 103, R. 63
Sec. 13, T. 103, R. 63

Sec. 13 , T. 103, R. 63

Sec. 24, T, 103, R. 63

Sec. $25, \mathrm{~T} .103, \mathrm{R} .63$.
Sec. $35, \mathrm{~T} .103, \mathrm{R} .63$

City of Plankinton, sec. $22, \mathrm{~T} .103, \mathrm{R} .64$

Plankinton Township well, sec. 22, T. $103, \mathbf{R} .64 . .$.

Plankinton.

Thos. Mullivan, NW. $\frac{1}{4}$ sec. $29, \mathrm{~T} .103, \mathrm{R} .64$

O. R Alld Plankinton.

Sec. 27 , T. 103 , R. 64 .

Hans Hanson, $\mathrm{s}$ W. $\frac{1}{4} \mathrm{sec} .3 \mathrm{i}, \mathrm{T}$. $103, \mathrm{R} .65 . \ldots \ldots \ldots$

A. H. Henneaus, sec. 34 , T. 103, R. 66 .

White Lake, T. 103, R. 66

White Lake, sec. 11, T. 103, R. 66 .

James Ryan, sec. 22, T. 104, R. 63

O. Scott, sec. 1 , T. 104, R. 63

A. D. Dougan, sec. 21, $T$, 104, R. 63

B. H. Sullivan, sec. 21, T. 104, R. 63 .

Sec. 2, T. 104, R. 63 .

Sec. 3 , T. 104, R. 63

Sec. 10 , T. 104, R. 63

Sec. 15, T. 104, R. 63

Sec. 17, T. 104, R. 63

Sec. 20, T. 104, R. 63.
Sec. 21, T, 104, R. 63

Sec. 21 , T, 104, R. 63

Sec. 26, T. 104, R. 63

Sec. 35, T. 104, R. fi3 .

Sec. 34, T. 104, R. 64

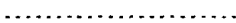

H. Koeman, jr., sec. 26, T, $104, \mathrm{R} .65$

A. W. Closson, sec. 3 , T. 104, R. 66 .

.

Sec. 24, T. 105, R. $63.2 \ldots$

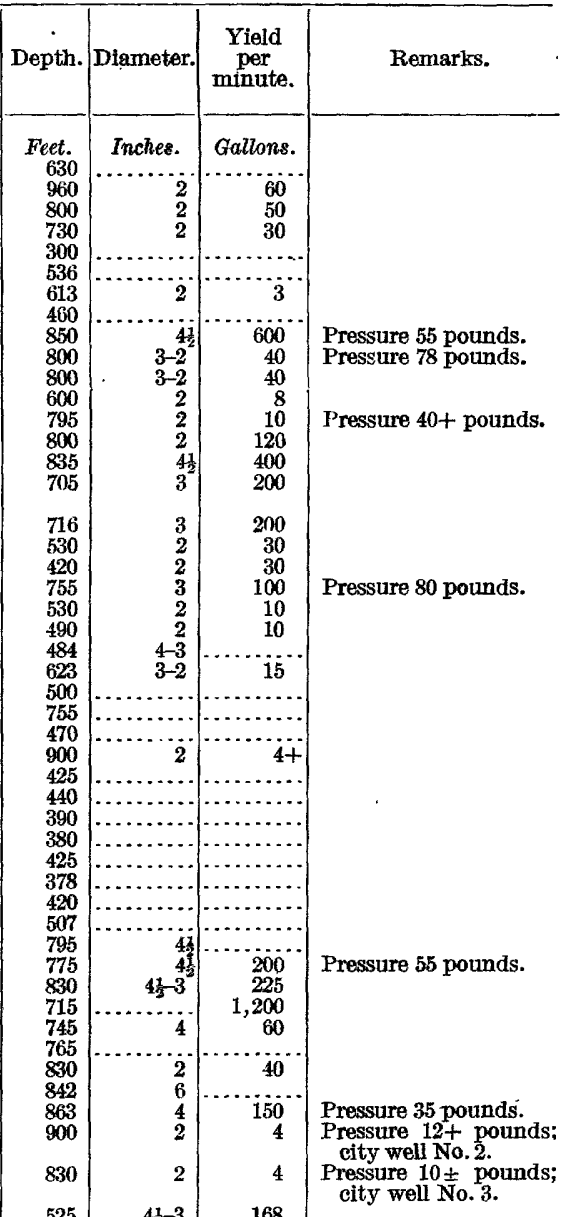




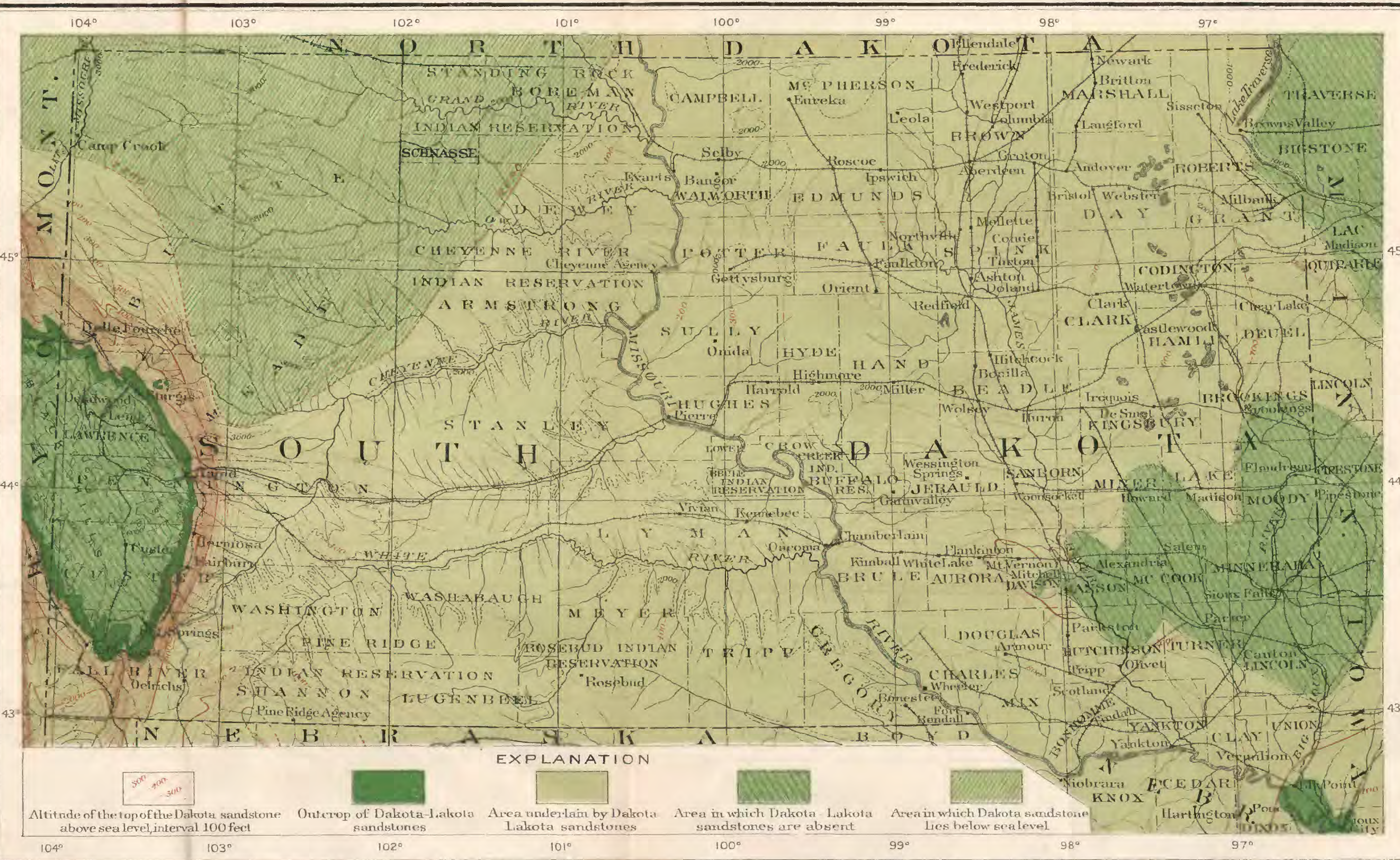

MAP OF SOUTH DAKOTA, SHOWING THE STRUCTURE OF THE DAKOTA SANDSTONE BY N. H. DARTON

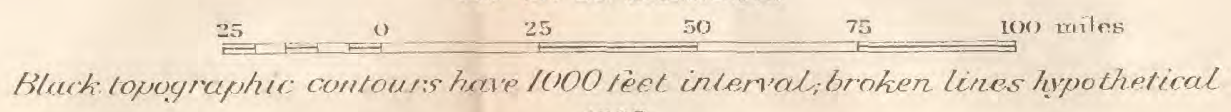


Representative artesian wells in Aurora County-Continued.

\begin{tabular}{|c|c|c|c|c|}
\hline & Depth. & Diameter. & $\begin{array}{c}\text { Yield } \\
\text { per } \\
\text { minute. }\end{array}$ & Remaxks. \\
\hline George Scott, 'T. 105, R. $63 \ldots$ & Feet. & Inches. & Gallons. & \\
\hline Sec. 2 , T. 105 , R. $63 . . . .$. & 400 & & & \\
\hline 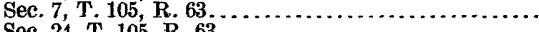 & 580 & n............ & ..... & \\
\hline 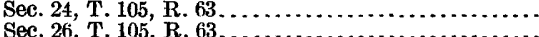 & $\begin{array}{l}500 \\
400\end{array}$ & 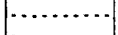 & $\ldots+\ldots$ & \\
\hline Do & 475 & (n............. & 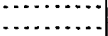 & \\
\hline Sec. $28, T .105$, R. $63 \ldots \ldots \ldots \ldots$ & $\begin{array}{l}508 \\
560\end{array}$ & n.......... & n........... & \\
\hline Sec. $35, \mathrm{~T}$ 105, R. $63 . \ldots$ & 620 & & & \\
\hline 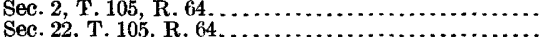 & $\begin{array}{l}640 \\
563\end{array}$ & & & - \\
\hline M. E. Lewis, SW. $\frac{1}{4}$ sec. 32, T. 105, R. $66 . \ldots \ldots \ldots$ & 1,222 & 3 & Few. & On high land; barely \\
\hline Mullen Bros., sec. 24, T. 105, R. $66 .$. & 953 & 2 & 60 & \\
\hline
\end{tabular}

Some representative deep-well records in Aurora County are as follows:

Record of well of J. W. Ryan, NE. $\frac{1}{4}$ sec. 10, T. 102, R. 63 .

Drift

Feet.

Shale (Pierre?) . . . . . . . . . . . . . $\ldots \ldots \ldots \ldots \ldots \ldots \ldots \ldots, 104$

Chalk rock (Niobrara) ............................. 104-214

Sand rock and sand; soft water...................... 214-324

Shale. . . . . . . . . . . . . . . . . . . . . . . . . . . . . 324-536

Sandstone..................................... 536-566

Shale. . . . . . . . . . . . . . . . . . . . . . . . . . . $566-576$

Sandstone with large flow of water. . . . . . . . . . . . . $576-580$

Shale.......................................... 580-614

The sand rock at 214 to 324 feet is at the top of the Carlile shale of the Benton group, which extends to the probable top of the Dakota sandstone at 536 feet.

Record of Raesley well, $S W . \frac{1}{4}$ sec. 28, T. 103, R. 63.

Drift

Féet.

Chalk rock (Niobrara)

0-.90

Sand rock, with soft water.

90-230

Blue shale.

$230-260$

Hard layers (probably Greenhorn limestone)............. 308-328

Shale ............. $\quad\left[\ldots \ldots \ldots \ldots \ldots \ldots \ldots . .628-477_{\text {, }}\right.$

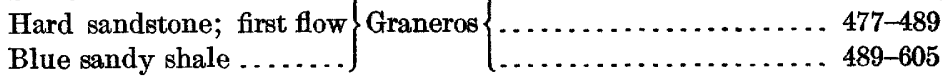

Sand rock; second flow, 100 gallons $) \quad(\ldots \ldots \ldots \ldots \ldots .605-610$

Shale, with hard layers ......... Dakota $\{\ldots \ldots \ldots \ldots \ldots .610-675$

Sandstone; third flow, 100 gallons.. $\} \quad[\ldots \ldots \ldots \ldots \ldots .675-705$

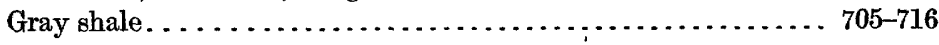

In this record the sandstone at the top of the Carlile shale at 230 feet is only 30 feet thick, and its amount is found to be extremely variable in other wells in the vicinity. 
Record of well of J. Asmuss, NW. $\frac{1}{4}$ sec. 1, T. 101, R. 64 .

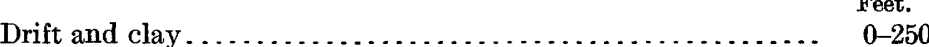

Chalk rock (Niobrara) . . . . . . . . . . . . . . . . . . . . . . 250-398

Sandstone, with soft water......................... $398-430$

Shale. . . . . . . . . . . . . . . . . . . . . . . . . . . . . 430-630

Sandstone and flow $\ldots \ldots \ldots \ldots \ldots \ldots \ldots \ldots \ldots \ldots \ldots \ldots, 630,632$

It is not certain that this well reaches the top of the Dakota sandstone, and it may flow from a first-flow sandstone low in the Graneros shale.

\section{Record of well at Plankinton.}

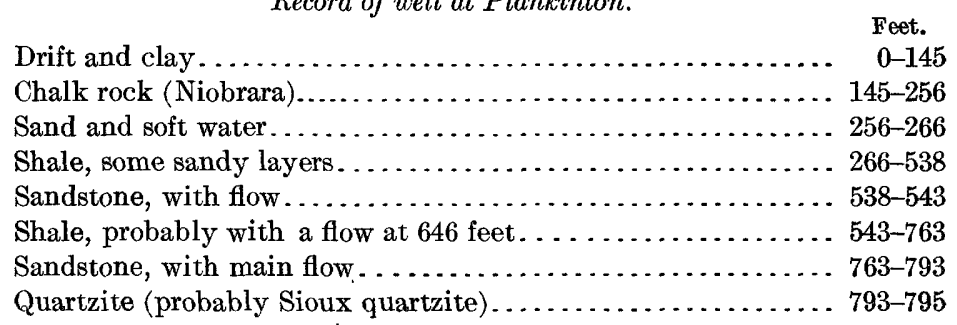

It is believed that the top of the Dakota lies at a depth of 538 feet in this well. Quartzite is reported at a depth of 850 feet at White Lake, with the top of Dakota sandstone at 790 feet.

The deepest well in the county so far reported is on the ranch of M. E. Lewis, in the SW. $\frac{1}{4}$ sec. 32, T. 105 N., R. 66 E. It has a depth of 1,222 feet, but only a light flow, probably owing to the height of the land on which it is situated. Samples of borings at $1,218,1,220,1,221$, and 1,222 feet were found to be hard sandstone with iron-oxide cement, undoubtedly Dakota sandstone.

\section{BEADLE COUNTY.}

Beadle County lies mainly in the James River valley, but its southwest corner extends up the slopes of the higher lands to the west. The surface is covered by glacial deposits varying in thickness from 50 to 300 feet, lying on Pierre clay. This clay is several hundred feet thick and is underlain by the usual succession of Niobrara formation, Benton shales and sandstones, and Dakota sandstone lying on granite and quartzite. The Niobrara formation is so shaly in this county that ordinarily it is not recognized by the well borers as distinct from the adjoining shale. The Benton group includes a bed of sandstone at its top and other thin beds of sandstone lower down, which contain water supplies, the upper sandstone yielding water for pumped wells and the lower sandstone yielding small first flows in the deep wells.

The Dakota sandstone contains a great volume of water under high pressure and affords a supply for a number of wells in all portions of the county. The sandstone lies nearly level, and, as the 
country is relatively flat, the variations in depth are not great. The depths of the majority of wells range from 750 to 1,100 feet, the deeper ones extending into the lower beds of the formation, where the flows usually have somewhat greater volume and higher pressure than those in the upper sandstone layers.

The following is a list of representative artesian wells in Beadle County:

Artesian wells in Beadle County.

\begin{tabular}{|c|c|c|c|c|}
\hline $\begin{array}{l}\text { Town- } \\
\text { ship. }\end{array}$ & Range. & Depth. & $\begin{array}{l}\text { Average } \\
\text { yield per } \\
\text { minute. }\end{array}$ & Remarks. \\
\hline & & Feet. & Gallons. & \\
\hline $\begin{array}{l}109 \\
109\end{array}$ & $\begin{array}{l}62 \\
63\end{array}$ & $\begin{array}{l}785-916 \\
806-856\end{array}$ & $\begin{array}{l}\text { 35-250 } \\
\text { Many. }\end{array}$ & Pressure 125 pounds. \\
\hline 109 & 64 & $830-910$ & $45^{\circ}$ & \\
\hline 110 & 59 & $\begin{array}{l}850 \\
857\end{array}$ & $\begin{array}{l}40 \\
50\end{array}$ & \\
\hline 110 & 60 & $\begin{array}{l}930 \\
790\end{array}$ & $\begin{array}{l}930 \\
111\end{array}$ & Pressure 100 pounds. \\
\hline & & 770 & & \\
\hline 110 & 61 & 879 & $150-200$ & Pressure 60 to 100 pounds. \\
\hline 110 & 62 & $\begin{array}{r}900 \\
784-1,139\end{array}$ & $350-2,250$ & $\begin{array}{l}\text { Pressure } 125 \text { pounds. } \\
\text { Pressure } 120 \text { to } 165 \text { pounds: Huron town wells. }\end{array}$ \\
\hline 110 & 63 & $104-1,109$ & $000-2,200$ & Fressure 120 uo 105 pounas; Huron towh weils. \\
\hline 110 & 64 & 847 & 100 & \\
\hline 110 & 65 & 870 & 50 & \\
\hline 111 & 59 & 940 & 20 & \\
\hline 111 & 59 & 925 & 50 & \\
\hline 111 & 61 & $\begin{array}{l}792 \\
836\end{array}$ & $\begin{array}{l}200 \\
360\end{array}$ & \\
\hline 111 & 62 & $744-788$ & 300 & . \\
\hline 111 & 63 & $780-918$ & $45-114$ & \\
\hline 111 & 64 & $784-870$ & $43-100$ & \\
\hline 111 & 65 & $\begin{array}{r}930 \\
1,000\end{array}$ & $\begin{array}{r}330 \\
80\end{array}$ & Pressure 137 pounds; Wolsey well. \\
\hline 112 & 59 & 913,933 & 35 & \\
\hline 112 & 60 & 779 & $400-600$ & Pressure 120 pounds. \\
\hline 112 & 61 & 778-917 & $\begin{array}{r}35 \\
600\end{array}$ & Pressure 125 (?) pounds. \\
\hline 112 & 62 & $793-817$ & $40-240$ & Pressure in one well, 50 pounds. \\
\hline 112 & 63 & $601-870$ & $16-200$ & Pressure in one well, 60 to 90 pounds; in another, 20 pounds. \\
\hline 112 & 64 & 900 & 45 & \\
\hline 113 & 60 & 810 & 200 & Pressure 115 pounds. \\
\hline 113 & 61 & $750-810$ & $60-125$ & \\
\hline 113 & 62 & 815 & 120 & Procsurn 100 (?) nounds \\
\hline 113 & $\begin{array}{l}03 \\
63\end{array}$ & $900-912$ & $\begin{array}{r}300 \\
50\end{array}$ & Fressure 100 (t) pounds. \\
\hline & & 953 & 1,260 & Pressure 150 pounds; Hitcheock well. \\
\hline $\begin{array}{l}113 \\
114\end{array}$ & $\begin{array}{l}64 \\
59\end{array}$ & $\begin{array}{r}980-1,118 \\
1,038\end{array}$ & $\begin{array}{r}20-1,435 \\
8\end{array}$ & Pressure in one well, 175 pounds. \\
\hline
\end{tabular}

\section{BONHOMME COUNTY.}

Bonhomme County extends northward from Missouri River into a region of plains and ridges. The greater part of the county is heavily drift covered, but there are extensive exposures of the underlying Niobrara chalkstone in the bluffs along the Missouri River. The higher lands of the ridges east of Choteau Creek are underlain by Pierre shale. The county lies in the Dakota artesian area, but the higher lands in its western portion are too high for flowing wells. In the valleys and on the broad plain in the central and eastern portion of the county there are numerous flowing wells, which obtain supplies of water at moderate depths. There is considerable varia- 
tion in the volume of water, a well at Springfield yielding 3,000 gallons a minute, while at Scotland the flow is small, owing to local conditions of diminished thickness and porosity of the sandstone. The following list gives the principal features of the deeper wells in this county from which reports have been received:

Artesian wells in Bonhomme County.

\begin{tabular}{|c|c|c|c|c|}
\hline $\begin{array}{l}\text { Town- } \\
\text { ship. }\end{array}$ & Range. & Depth. & $\begin{array}{l}\text { Average } \\
\text { yield per } \\
\text { minute. }\end{array}$ & Remarks. \\
\hline $\begin{array}{l}92 \\
93 \\
93 \\
93 \\
93 \\
93 \\
93 \\
93 \\
94 \\
94 \\
94 \\
94 \\
95 \\
96 \\
96\end{array}$ & $\begin{array}{l}60 \\
58 \\
59 \\
60 \\
60 \\
60 \\
61 \\
62 \\
58 \\
59 \\
59 \\
61 \\
59 \\
58 \\
59\end{array}$ & $\begin{array}{r}\text { Feet. } \\
885,920 \\
630-665 \\
530-855 \\
620 \\
592 \\
828 \\
735-1,000 \\
862(?), 897 \\
576-645 \\
552-752 \\
857 \\
1,0742 \\
730-828 \\
582-680 \\
590-700\end{array}$ & $\begin{array}{r}\text { Gallons. } \\
95-100 \\
15-252 \\
700 \\
3,292 \\
72 \\
25-70 \\
1,400-1,600 \\
11-100 \\
13-150 \\
1,000 \\
26-97^{\frac{1}{3}} \\
9 \\
\text { Few. }\end{array}$ & $\begin{array}{l}\text { Pressure in } 885 \text {-foot well, } 30 \text { pounds. } \\
\text { Pressure } 42 \text { to } 45 \text { pounds. } \\
\text { Pressure } 40 \text { to } 66 \text { pounds. } \\
\text { Springfield city well. } \\
\text { Pressure } 86 \text { pounds; in Springfield mill. } \\
\text { Pressure } 86 \text { pounds; city well. } \\
\text { Pressure } 12 \text { to } 14 \text { pounds. } \\
\text { Pressure } 62 \text { to } 58 \text { pounds. } \\
\text { Pressure } 40 \text { pounds. } \\
\text { Pressure in } 752 \text {-foot well, } 40 \text { pounds. } \\
\text { Pressure } 30 \text { pounds; city of Tyndall. } \\
\text { Pressure } 2 \frac{1}{2} \text { pounds. } \\
\text { Scotland wells. }\end{array}$ \\
\hline
\end{tabular}

The well at Springfield is a phenomenal one, with its flow of 3,292 gallons per minute, although its closed pressure is not so great as that of many other wells in the State. It furnishes power for a 60-barrel flour mill by day and for an electric-light plant by night. For awhile it threw sand, and when this finally ceased the flow was thought to have slightly decreased. The city well when finished was for some time allowed to run at full head, and it was then observed that the flow of the mill well was noticeably weakened for the time being.

The first well at Scotland was sunk to a depth of 582 feet, of which the last 52 feet were in "quartzite." The water supply found in sand on the surface of this quartzite was so small that the well was regarded as a practical failure. Not far from the old well another was recently sunk through a hard sandstone bed into clear white sand at 590 feet, but obtained no increase in flow. The Layson well was sunk on the high ridge between Emanuel and Choteau creeks to a depth of 1,074 feet. Only a feeble flow was found, and the pressure was sufficient to raise the water only about 7 feet above the surface. The wells at Tyndall, those in the southeast corner of the county, and those in the Missouri bottom near the mouth of Choteau Creek yield more satisfactory supplies.

The artesian waters in Bonhomme County, except those at Scotland, Layson, and the mouth of Choteau Creek, all appear to come from approximately the same horizon. At Scotland the waters seem to be largely cut off by a ridge of the quartzite bed rock. The Layson well 
was apparently sunk to a hontizon considerably below that of the group of successful wells to the east and south. The low pressure in this well is due to the height of the land on which the well is sunk, and the small volume of water is no doubt due to some variation in texture, such as occurs locally in the Dakota sandstone. The wells at the mouth of Choteau Creek appear to draw their waters from a horizon somewhat lower than that at Springfield and Tyndall. Probably it is the same horizon as that at which is found the small flow at the Layson well on the ridge to the northeast, but here the sandstone is so porous as to furnish a larger volume of water.

The head of the waters in Bonhomme County is considerably less than it is farther north, for the amount decreases rapidly to the south and east in this region. It appears, however, to be sufficient to bring the water to the surface over all of the county, with the probable exception of the high ridge between Emanuel Creek and Choteau Creek.

The wells in Bonhomme County disclose much diversity in the underground geology. After passing through the drift they enter the chalk rock, which, having an irregular surface and thickness, varies considerably in amount. It is usually underlain by the upper sandstone of the Carlile formation, in some places separated from the chalk by olay, which yields considerable water to some of the deeper pumped wells in the county. The underlying Benton includes beds of limestone and sandstone, the latter locally yielding small first flows. The thickness of the Benton and of the underlying Dakota appears to vary considerably. Under Scotland the Dakota sandstone is very thin. At Springfield it is penetrated for 50 feet, and in the Layson well, on the high ridge west of Springfield, a continuous bed of sandstone is reported at 810 to 1,043 feet, containing but little water and separated from a very hard rock, presumably granite or quartzite, by a small mass of shale. The record of the Scotland well, kindly furnished by $\dot{A}$. E. Swan, is as follows:

Record of well at Scotland, Bonhomme County.

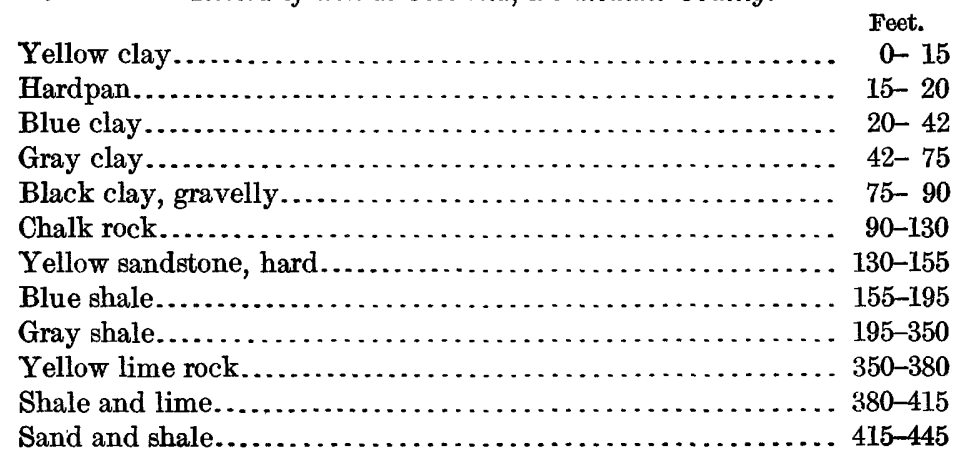




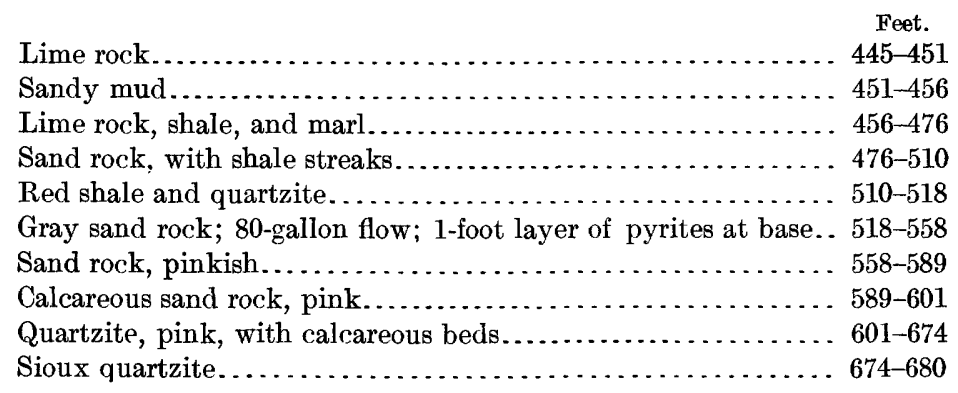

This record is probably more accurate than some others which have been published, in indicating a thickness of 120 feet of chalk under the drift.

\section{BROOKINGS COUNTY.}

Brookings County is in the drainage basin of Big Sioux River, on the east coteau, and ranges in altitude from about 1,600 to 1,800 feet. The region is heavily mantled by glacial drift and underlain by a considerable thickness of Pierre shale. To the south and east the Sioux quartzite appears to rise rapidly, and probably the Dakota sandstone is cut off by it in all of the area east of Volga and south of White. In the area underlain by the Dakota sandstone the altitude of the land is too high for the water to flow.

At Brookings a boring was made several years ago that is said to have reached the quartzite at a depth of about 556 feet. It obtained a small amount of water in overlying sandy beds, probably in the Benton group, but the pressure was not sufficient to afford a flow. A well at Elkston is 230 feet deep, with the last 30 feet in sandstone which is probably at the top of the Benton group.

\section{BROWN COUNTY.}

Brown County lies in the James River valley, and consists almost entirely of a level plain traversed by a few shallow depressions carrying the drainage. It is covered with glacial deposits, but from numerous well borings these are known to be underlain by a thick mass of Pierre shale and underlying Niobrara, Benton, and Dakota beds, resting on quartzite and granite. The strata lie very nearly level and the average depth to the top of the Dakota sandstone is between 850 and 1,000 feet. The sandstone contains a great volume of water, yielding large flows, most of which have a pressure considerably more than 100 pounds to the square inch, the amount varying somewhat in different portions of the county. In 1906 it was estimated that there were about 300 artesian wells in active operation in the county. 
The depth and other features of these wells are given in the following table:

Artesian wells in Brown County.

\begin{tabular}{|c|c|c|c|c|}
\hline $\begin{array}{l}\text { Town- } \\
\text { ship. }\end{array}$ & Range. & Depth. & $\begin{array}{l}\text { Yield per } \\
\text { minute. }\end{array}$ & Remarks. \\
\hline 121 & 60 & Feet. & Gallons. & \\
\hline 121 & 61 & 900,940 & 14,43 & Pressure 168 pounds. \\
\hline 121 & 62 & $\begin{array}{l}930,960 \\
898-980\end{array}$ & 106,306 & \\
\hline $\begin{array}{l}121 \\
121\end{array}$ & $\begin{array}{l}63 \\
64\end{array}$ & $\begin{array}{r}898-980 \\
1,000\end{array}$ & $\begin{array}{r}33-96 \\
96\end{array}$ & Warner town well. \\
\hline 121 & 64 & $903-1,015$ & $35-96$ & Pressure $20-60$ pounds. \\
\hline 121 & 65 & 1,070 & 46 & \\
\hline 122 & 60 & $940-1,000$ & $15-76$ & Town of Ferney. \\
\hline 122 & 61 & $900-960$ & $39-70$ & Pressure 125 pounds. \\
\hline 122 & 63 & $920-940$ & $25-34$ & Pressure 120 pounds. \\
\hline 122 & 64 & 1,000 & 30 & \\
\hline 122 & 65 & 1,080 & 37 & Do \\
\hline 123 & 60 & $920-977$ & $10-105$ & Pressure 80 pounds. \\
\hline 123 & 60 & 922,960 & 830 & Pressure 135 pounds; Groton town wells Nos. 1 and 2. \\
\hline 123 & 61 & $920-935$ & $15-123$ & \\
\hline $\begin{array}{l}123 \\
123\end{array}$ & $\begin{array}{l}62 \\
63\end{array}$ & 900 & $\begin{array}{r}95 \\
31-96\end{array}$ & \\
\hline 123 & 64 & $918-1,117$ & $250,1,060$ & Aberdeen town wells. Pressures 40 to 138 pounds. The \\
\hline 123 & 64 & 1,300 & 1,350 & Aberdeen city well No. 3 . \\
\hline 123 & 64 & 1,300 & 1,000 & Aberdeen city well No. 4 . \\
\hline $\begin{array}{l}123 \\
124\end{array}$ & $\begin{array}{l}65 \\
60\end{array}$ & $\begin{array}{r}1,070-1,167 \\
885-942\end{array}$ & $\begin{array}{r}25-53 \\
88-150\end{array}$ & Prossure in 042 foot well 127 nounds \\
\hline 124 & 61 & $\begin{array}{r}000-942 \\
912\end{array}$ & & Fressure in 94z-100i wen izf pounus. \\
\hline 124 & 62 & 900 & 25 & \\
\hline 124 & 63 & 945 & 123 & . \\
\hline $\begin{array}{l}124 \\
125\end{array}$ & $\begin{array}{l}64 \\
61\end{array}$ & $875-975$ & $15-31$ & \\
\hline 125 & 62 & $872-1,002$ & $25-940$ & Largest yield at Columbia, pressure 160 pounds. \\
\hline 125 & 63 & $942-983$ & $30-35$ & \\
\hline $\begin{array}{l}125 \\
125\end{array}$ & $\begin{array}{l}64 \\
65\end{array}$ & $\begin{array}{r}1,050 \\
1,021-1,100\end{array}$ & $21-48$ & \\
\hline 126 & 60 & $1,021-1,900$ & $\begin{array}{r}21-78 \\
248\end{array}$ & \\
\hline 126 & 61 & 965 & $\cdots \cdot$ & Pressure 135 pounds; several flows. \\
\hline 126 & 64 & 1,030 & & Pressure 35 pounds. \\
\hline 126 & 65 & $1,073-1,150$ & $17-136$ & \\
\hline $\begin{array}{l}127 \\
127\end{array}$ & 61 & 9060 & 56 & \\
\hline 127 & 62 & 800,956 & 35,36 & \\
\hline 127 & 64 & $1,094-1,200$ & $10-139$ & Frederick city well; 139-gallon flow, pressure 70 pounds. \\
\hline $\begin{array}{l}127 \\
128\end{array}$ & $\begin{array}{l}65 \\
60\end{array}$ & $1,084-1,200$ & & \\
\hline 128 & 61 & $920-1,270$ & $20-144$ & \\
\hline 128 & 62 & 975 & 100 & \\
\hline
\end{tabular}

These wells passed through a great thickness of gray and blue clays, representing the Pierre, Niobrara, and Benton. In the Benton there was generally found a thin bed of sandstone yielding a small amount of first-flow water. The Dakota sandstone is usually overlain by hard cap rock and consists of a succession of soft sandstone layers, with bodies of shale and sandy shale varying in thickness from a few feet to 50 or 60 feet in some wells. All the sandstones contain water, but the volume and pressure usually increase in the lower beds. In the Aberdeen city well No. 4 the base of the formation was found to consist of 49 feet of sand without much water, underlain by quartzite and granite, the top of the granite being entered at a depth of about 1,267 feet. 


\section{BRULE COUNTY.}

Brule County extends eastward from Missouri River and is in greater part an elevated plateau, or region of gently rolling plains, from 300 to 400 feet higher than the river. In the southern portion the Bijou Hills rise still higher, their altitude probably being somewhat over 2,000 feet. All the highlands are covered by glacial drift lying on Pierre shale. The Bijou Hills are capped by Tertiary sands and green quartzite. Missouri River cuts through the Pierre shale and exposes the Niobrara chalkstone in the lower valley slopes.

The artesian waters of this county have been extensively developed, for more than 60 wells are reported, most of them between 800 and 1,000 feet in depth. Nearly all of them furnish large flows of excellent water, which is used mainly for irrigation. One of the wells near Chamberlain is reported to have a flow of 3,000 gallons per minute. The average flow of a 6 -inch well is about 500 gallons, and of a 2-inch well, of which there are many, from 50 to 150 gallons. On the higher lands the pressures are moderate, but in some places rise above 50 pounds per square inch. Wells on the lower lands have greater pressure, one of the city wells in Chamberlain having over 100 pounds and developing 10 horsepower.

The greater part of the water is obtained in the upper part of the Dakota sandstone, but in a region extending through Kimball the upper beds are too compact to yield much water and it is necessary to sink to a looser sandstone below. Artesian waters appear to be available throughout this county, except on the higher portions of the Bijou Hills. The following is a list of wells in Brule County, arranged by townships:

Artesian wells in Brule County.

\begin{tabular}{|c|c|c|c|c|}
\hline $\begin{array}{l}\text { Town- } \\
\text { ship. }\end{array}$ & Range. & Depth. & $\begin{array}{l}\text { Yield per } \\
\text { minute. }\end{array}$ & Remarks. \\
\hline 101 & & Feet. & Gallons. & \\
\hline $\begin{array}{l}101 \\
101\end{array}$ & $\begin{array}{l}67 \\
68\end{array}$ & $\begin{array}{l}750-950 \\
815-962\end{array}$ & $\begin{array}{r}18-60 \\
20-1,098\end{array}$ & $\begin{array}{l}\text { Pressure } 20 \text { to } 40 \text { pounds. } \\
\text { Pressure } 12 \text { to } 25 \text { pounds. }\end{array}$ \\
\hline 102 & 67 & $750-880$ & $18-100$ & Pressure 40 pounds in some wells. \\
\hline 102 & 68 & $800-1,050$ & $9-1,000$ & Pressure in one well 10 pounds. \\
\hline 102 & 69 & 900 & $50-800$ & Pressure 5 to 40 pounds. \\
\hline 102 & 70 & $1,027-1,230$ & $400-900$ & Pressure 2 to 40 pounds. \\
\hline 102 & 71 & $1,230-1,270$ & $45-605$ & \\
\hline $\begin{array}{l}103 \\
103\end{array}$ & $\begin{array}{l}67 \\
68\end{array}$ & $\begin{array}{r}840-956 \\
900-1,210\end{array}$ & $\begin{array}{r}40-90 \\
60-750\end{array}$ & \\
\hline & & 1,254 & 185 & Kimball city wells; original pressure 7 to 20 pounds. \\
\hline 103 & 69 & $983-1,210$ & $\begin{array}{r}12-60 \\
25-1-000\end{array}$ & Pressure 40 pounds. \\
\hline $\begin{array}{l}103 \\
104\end{array}$ & $\begin{array}{l}71 \\
68\end{array}$ & $1,063,1,100$ & $\begin{array}{r}25-1,000 \\
128\end{array}$ & \\
\hline 104 & 69 & $940-1,200$ & $60-70$ & \\
\hline 104 & 70 & 927 & $\begin{array}{l}1,385 \\
3-300\end{array}$ & Flows at 890 and 903 feet. \\
\hline 104 & 71 & 645,670 & 4,500 & Chamberlain Electric Co.'s wells Nos. 1 and 2; supply and \\
\hline 104 & 71 & $540-600$ & $1,450-5,000$ & $\begin{array}{l}\text { pressure diminished. } \\
\text { Quarnberg's four wells; flow decreasing. }\end{array}$ \\
\hline 104 & 71 & 815,960 & 537,700 & Chamberlain city wells Nos. 1 and 2 ; supply greatly dimin- \\
\hline 105 & 67 & 940 & 80 & Isted. \\
\hline 105 & 68 & $930-987$ & $300-815$ & Pressure 5 to 75 pounds. \\
\hline 105 & 69 & 1,075 & & Flows at 990 and 1,060 feet. Pressure 16 pounds. \\
\hline
\end{tabular}


Two representative well sections in this county are as follows:

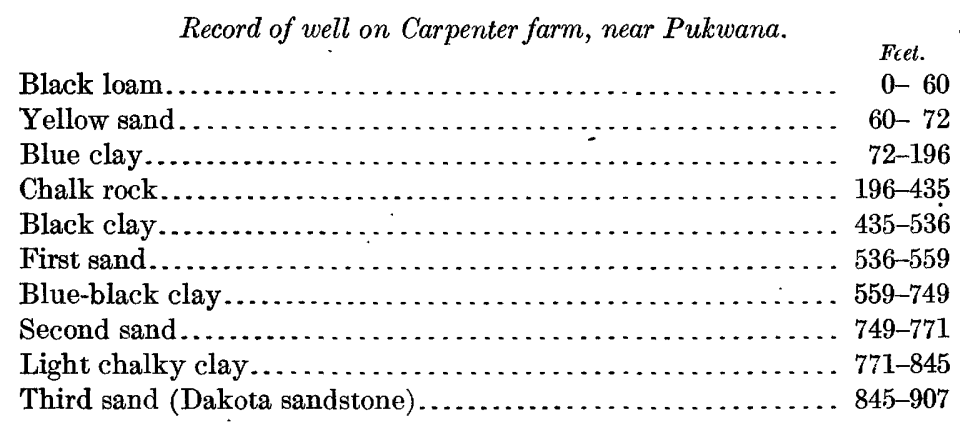

This well is on high land and the chalk rock is overlain by over 100 feet of Pierre clay.

\begin{tabular}{|c|c|}
\hline \\
\hline Sand and gravel $\ldots \ldots \ldots \ldots \ldots \ldots \ldots \ldots \ldots \ldots \ldots$ & $\begin{array}{l}\text { Feet. } \\
0-22\end{array}$ \\
\hline & $22-42$ \\
\hline $\mathrm{Ch}$ & $42-$ \\
\hline below.... & $132-$ \\
\hline & \\
\hline Tor & -555 \\
\hline San & $555-584$ \\
\hline Fin & $584-612$ \\
\hline $\mathrm{Ha}$ & $612-619$ \\
\hline , & 619-633 \\
\hline 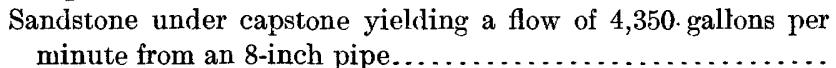 & \\
\hline
\end{tabular}

The chalk rock in this section is in the lower portion of the Niobrara, and the Benton shales appear to extend from 132 to 555 feet in depth.

In its lower part the deep boring at Kimball penetrated very hard, dry sandstones, which, it was thought, might possibly be Sioux quartzite. Samples forwarded by the driller from depths of $1,157,1,175$, $1,190,1,210,1,225,1,240$, and 1,246 feet represented $h a r d$ buff sandstone with considerable oxide of iron in their cement, especially in the 1,246-foot sample. Iron sandstones were also penetrated from 1,130 to 1,138 feet and 1,140 to 1,150 feet; hard, sandy clay from 1,150 to 1,155 feet; buff sandstone at 1,143 feet; and buff clay from 1,153 to 1,170 feet.

\section{BUFFALO COUNTY. ${ }^{a}$}

In Buffalo County the geologic conditions are similar to those in Brule County, but the depth to the Dakota sandstone is slightly greater, the strata dipping gently to the northwest and the land rising slightly as the river is ascended. It is probable that the depth 
to the sandstone is about 900 feet at the northwest end of the county in the Missouri Valley and 1,100 to 1,200 feet in the higher lands.

To judge from the pressure observed in wells in this and the surrounding counties artesian flows may be expected throughout the county, except possibly on the very highest summits northwest of Gann. Several wells are reported; one at Crow Creek Agency, another in sec. 1, T. 108, R. 70, and a third on the south branch of Crow Creek below Vega. The last has a depth of 875 feet and a flow of 135 gallons per minute of hard water, with a pressure estimated at 75 pounds. It is a 2-inch well, and the first flow was reported at 800 feet. The well in the SW. $\frac{1}{4}$ sec. 1, T. $108, R$. 70 , is said to be 1,450 feet deep and 2 inches in diameter, and has a flow of 27 gallons per minute. The water rises 20 feet or more above the ground.

The well at the Crow Creek Agency was sunk in 1896 by the United States Indian Bureau. It has a depth of about 780 feet and is 6 inches in diameter. The flow is very large, and it is stated that the column of water rises 5 feet above the surface when the well is wide open. The closed pressure exceeded 180 pounds, the total registering capacity of the gauge. With a $1 \frac{5}{8}$-inch nozzle outlet the remaining pressure is 85 pounds; with a $1 \frac{7}{8}$-inch nozzle outlet, 70 pounds; and with a 2 -inch nozzle, 65 pounds. The temperature of the water is $72^{\circ} \mathrm{F}$. and its specific gravity 1.004 . The well at first threw out white sand, but this discontinued after a while, and its subsequent behavior has been entirely satisfactory. The first flow was found at 409 feet, but its head was barely sufficient to bring the water above the surface. The final flow was reached at 760 feet, and the water-bearing sand penetrated to a depth of 20 feet. The following record is based on a few samples, with explanatory notes by the agent:

Record of artesian well at Crow Creek Agency, on Missouri River, Buffalo County.

\begin{tabular}{|c|c|}
\hline Gravelly beds, some clay & $\begin{array}{l}\text { Feet. } \\
40-78\end{array}$ \\
\hline Gray clay on thin bed of small gravel. & $78-88$ \\
\hline Gray shale $\ldots \ldots \ldots \ldots \ldots$ & $88-242$ \\
\hline Gray limestone $\ldots \ldots \ldots \ldots \ldots$ & $242-252$ \\
\hline Gray chalk, etc., with first flow at 409 feet... & $252-409$ \\
\hline 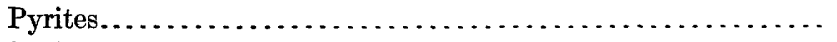 & $409-435$ \\
\hline Shale (?) on 3-foot layer of pyrites. & $435-700$ \\
\hline Shale, with pyrites... & $700-760$ \\
\hline Sandstone, main flow. & $760-780$ \\
\hline
\end{tabular}

\section{BUTTE COUNTY.}

Butte County occupies the northwest corner of the State, with an area of over 8,500 square miles, lying mainly on the Great Plains. Its northwest corner is crossed by the Black Hills uplift, exposing formations from the Spearfish red beds upward. The northern, central, and eastern portions of the county are occupied by a consider- 
able thickness of Fox Hills and overlying formations, the Dakota sandstone lying more than 2,500 feet below the surface in the lowest valleys. The Fox Hills and overlying sandstones contain local water supplies, which may be available in deep wells, but their capabilities in this respect have not yet been tested.

The greater part of the region lying between Indian Creek and Owl River is underlain by the Pierre shale, and the Dakota sandstone appears to be within reach of deep borings; but to judge from the pressures exhibited in the wells at Belle Fourche, the country is too high for artesian flows. Between Indian Creek and the hogbacks of Dakota sandstone south of Belle Fourche there is a district extending northwest and southeast in which the Dakota sandstone waters are available at depths ranging from slightly:more than 300 feet just south of Belle Fourche to about 2,000 feet on Indian Creek, the rate increasing as the formation descends in its dip to the northeast.

Artesian wells and deep borings in Butte County.

\begin{tabular}{|c|c|c|c|c|c|c|}
\hline & Depth. & $\begin{array}{l}\text { Depth } \\
\text { to main } \\
\text { flow. }\end{array}$ & $\begin{array}{l}\text { Diam- } \\
\text { eter. }\end{array}$ & $\begin{array}{l}\text { Yield } \\
\text { per } \\
\text { minute. }\end{array}$ & $\begin{array}{l}\text { Pres- } \\
\text { sure. }\end{array}$ & Remarks. \\
\hline $\begin{array}{l}\text { Belle Fourche city wells: } \\
\text { No. } 1, \ldots \\
\text { No. } 2 \ldots \ldots\end{array}$ & $\begin{array}{rr}\text { Feet. } \\
1 \quad 550 \\
525\end{array}$ & Feet. & $\begin{array}{c}\text { Inches. } \\
\text { n....... }\end{array}$ & $\begin{array}{l}\text { Gallons. } \\
\text { (n) }\end{array}$ & $\begin{array}{c}\text { Pounds. } \\
55\end{array}$ & 1 \\
\hline No. $3 . \ldots \ldots$ & 881 & 560 & & 30 & & \\
\hline $\begin{array}{l}\text { Belle Fourche, many small } \\
\text { wells. }\end{array}$ & $300-400$ & ….... & $1-2$ & 1 & .... & First flow; soft. \\
\hline Belle Fourche, Craft's addition & 897 & 560 & & 45 & 55 & $\begin{array}{l}\text { Second flow; small one at } \\
340 \text { feet. }\end{array}$ \\
\hline $\begin{array}{l}\text { Land and Cattle Company, } \\
\text { NW. } \frac{1}{4} \text { sec. } 11, \text { T. } 8, \text { R. } 2 .\end{array}$ & 635 & 635 & 1 & Many. & 55 & $\begin{array}{l}\text { Second flow; first flow at } \\
450 \text { feet, in valley; hard. }\end{array}$ \\
\hline 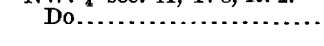 & 745 & 680 & & 15 & 40 & $\begin{array}{l}\text { Second flow; water also at } \\
450 \text { and } 650 \text { feet. }\end{array}$ \\
\hline $\begin{array}{l}\text { F. A. Durst, NW. } \frac{1}{4} \text { sec. } 14, T \text {. } \\
8, \text { R. } 2 \text {. }\end{array}$ & 550 & 500 & $4 \frac{1}{2}$ & 100 & $26+$ & \\
\hline $\begin{array}{l}\text { F. N. \& G. S. Fuller, NW. } \frac{1}{4} \\
\text { sec. 6, T. } 8, \text { R. } 3 \text {. }\end{array}$ & 835 & 800 & 2 & 30 & 15 & First flow; very soft. \\
\hline $\begin{array}{l}\text { J. A. Gilbert, SE. } \frac{1}{4} \text { sec. } 36, \text { T. } \\
9, \text { R. } 2 \text {. }\end{array}$ & 836 & 814 & 2 & 15 & & $\begin{array}{l}\text { Soft. Some water at } 600 \\
\text { feet. }\end{array}$ \\
\hline $\begin{array}{l}\text { Orman \& Crook, SW. }{ }_{4} \text { sec. } 19, \\
\text { T. } 9, \text { R. } 4 .\end{array}$ & 1,417 & 1,325 & $3-2$ & 60 & & $\begin{array}{l}\text { Flow also at } 1,345 \text { feet; } \\
\text { temperature, } 94^{\circ} \text {. }\end{array}$ \\
\hline H. L. Barnett, SE. $\frac{1}{4}$ sec. 31, & 935 & & 2 & 5 & & First flow; soft. \\
\hline $\begin{array}{l}\text { J. Wichert, SE. } \frac{1}{4} \text { sec. } 24 \text {, T. } 8 \text {, } \\
\text { R. } 2 \text {. }\end{array}$ & 381 & $360+$ & & 2 & 30 & $\begin{array}{l}\text { First flow; soft; sandstone } \\
\text { begins at } 280 \text { feet. }\end{array}$ \\
\hline $\begin{array}{l}\text { Case ranch, SE. } \frac{1}{2} \text { sec. } 14, \text { T. } 8 \text {, } \\
\text { R. } 2 \text {. }\end{array}$ & 241 & ( & $1 \frac{1}{4}$ & 2 & 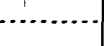 & First flow; very soft. \\
\hline G. H. Ray, SE. 1 sec. 12 T. 8 & $\begin{array}{l}355 \\
818\end{array}$ & 760 & $\frac{41}{2}$ & $\begin{array}{r}40 \\
5\end{array}$ & 26 & $\begin{array}{l}\text { Soft. } \\
\text { Water also at } 500 \text { feet; } \text { hard. }\end{array}$ \\
\hline R. 2 . & & & 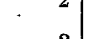 & & & \\
\hline $\begin{array}{l}\text { U. S. Reclamation Service, } \\
\text { SE. } \frac{1}{4} \text { sec. } 36 \text {, T. } 9 \text {, R. } 2 \text {. }\end{array}$ & 627 & 625 & 2 & 20 & & $\begin{array}{l}\text { First flow at } 567 \text { feet; shale } \\
\text { between. }\end{array}$ \\
\hline $\begin{array}{l}\text { U. S. Reclamation Service, } \\
\text { SE. } \frac{1}{4} \text { sec. 18, T. 9, R. } 4 \text {. }\end{array}$ & 1,388 & 1,380 & 2 & 1 & $9+$ & w \\
\hline $\begin{array}{l}\text { Newland ranch, SW. } \frac{1}{4} \text { sec. } 4 \text {, } \\
\text { T. } 8, \text { R. } 3 \text {. }\end{array}$ & 1,033 & 1,013 & 2 & 15 & 15 & . \\
\hline $\begin{array}{l}\text { Brant's road ranch, SE. } \frac{1}{4} \text { sec. } \\
23, \text { T. } 10, \text { R. } 2 .\end{array}$ & 2,019 & & & & Flows. & \\
\hline $\begin{array}{l}\text { Fred Ross, NW. } \frac{1}{4} \text { sec. } 4, \text { T. } 9 \text {, } \\
\text { R. } 4 \text {. }\end{array}$ & 1,858 & 1,783 & $1 \frac{1}{4}$ & $3 \frac{1}{2}$ & & First flow; soft. \\
\hline $\begin{array}{l}\text { M. Snyder, SE. } \frac{1}{4} \text { sec. } 13 \text {, T. } 8 \text {, } \\
\text { R. } 4 \text {. }\end{array}$ & $1,096 \frac{1}{2}$ & 1,080 & 2 & 60 & Flows. & First flow; soft but irony. \\
\hline $\begin{array}{l}\text { J. A: Scotney, NE. } \frac{1}{4} \text { sec. } 20 \text {, } \\
\text { T. } 8 \text {, R. } 2 \text {. }\end{array}$ & 330 & & 4 & 25 & 30 & \\
\hline Do..... & 225 & & 6 & 15 & $\mathrm{i5}$ & Hard. \\
\hline $\begin{array}{l}\text { 8. R. } 2 . \\
\text { W.R. Glassie, NE. } \frac{1}{4} \text { sec. } 28 \text {, }\end{array}$ & 320 & & & & 5 & Second flow. \\
\hline $\begin{array}{l}\text { D. Richardson, Hay Creek, } 6 \\
\text { miles west of Belle Fourche, }\end{array}$ & 220 & & 4 & 25 & & $\begin{array}{l}\text { Water rises } 9 \text { inches above } \\
\text { pipe. }\end{array}$ \\
\hline
\end{tabular}


Artesian wells and deep borings in Butte County-Continued.

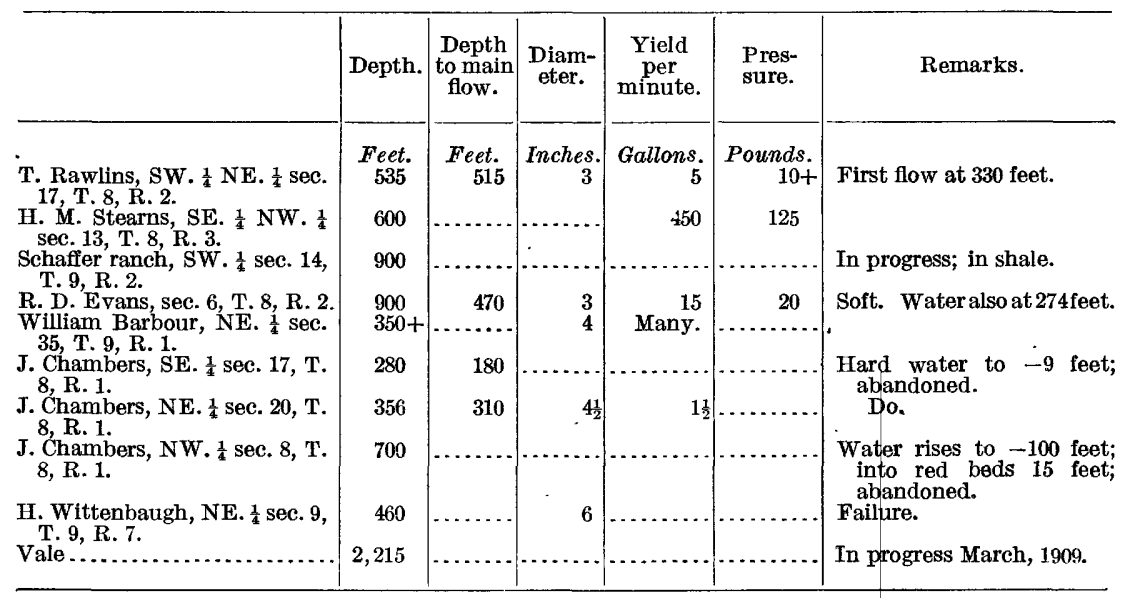

Belle Fourche and vicinity.-Since 1904 the village of Belle Fourche has been supplied by water from artesian wells which penetrate the Dakota or underlying sandstones. The deeper wells have sufficient pressure to flow into a tank 75 feet high, on a knoll just south of the railroad depot. Shallower wells afford supplies at various residences. The first well had a depth of $525 \frac{1}{2}$ feet, flowed 60 gallons a minute, and originally had a pressure of considerably more than 55 pounds to the square inch. It finally got out of order, apparently owing to a break in the casing, and other wells were sunk which obtained additional supplies. The materials penetrated in the first well were as follows: Shales, 207 feet; sandstone (Dakota), 100 feet, yielding a small flow at a depth of 245 feet; soft clay (Fuson), 118 feet, containing a thin layer of sand yielding a small second flow; and sandstone (Lakota), 100 feet. The Lakota sandstone contained water at various horizons with gradually increasing volume and head, the maximum flow being at about 510 feet in the lower part of the formation. The second well, on somewhat lower land near the center of the village, had the following record:

Record of second well at Belle Fourche.

Feet.

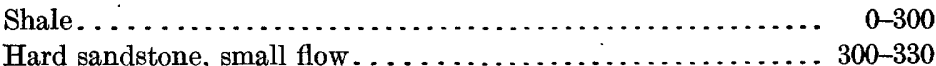

Soft sandstone with flow at 410 feet (Dakota sandstone) ........ 330-410

Red, white, and mottled clay (Fuson formation) . . . . . . . . . 410-435

Gray sandy clay and sandstone with lignite fragments (Lakota).. 435-470

Sandstone.................................... 470-525

A pressure of 45 pounds is reported in this well.

A third well, bored in 1903 to a depth of 881 feet, found water-bearing strata at intervals from 297 to 560 feet. The well is 4 inches in

- diameter and has a flow of 30 gallons a minute. Several small wells in the village are supplied by the first flow at depths of 300 to 400 feet. 
A well in Craft's addition, three-fourths of a mile east and one-fourth mile south of well No. 1 , is 560 feet deep to the second flow, with a pressure of 55 pounds. This well was drilled to 897 feet with no increase of water below 560 feet.

There are two artesian wells on property of the Belle Fourche Land and Cattle Company in the NE. $\frac{1}{4}$ NW. $\frac{1}{4}$ sec. 11 , T. 8 N., R. 2 E., a mile north of the village. The first, which was sunk in 1904 has a depth of 650 feet. It draws from the second flow, at 635 feet. The water is somewhat hard and the pressure is 55 pounds. A first flow, of softer water, was found at a depth of 450 feet. The following record is given:

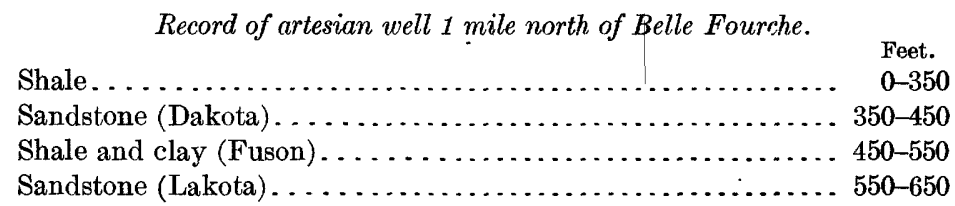

$A^{\prime}$ second well, on a small knoll north of the river in the northwest quarter of the same quarter section, has a depth of 744 feet. It yields a 15-gallon flow of soft water under pressure of 40 pounds. A small flow was found at a depth of 650 feet in this well.

F. Durst has a well in the NE. $\frac{1}{4}$ NW. $\frac{1}{4}$ sec. 14 , T. 8 N., R. 2 E., on a hill about 70 feet above Belle Fourche. It was sunk in 1906, has a diameter of $4 \frac{1}{2}$ inches and a depth of 550 feet, and found the main flow at 500 feet and minor flows at 350 and 400 feet. The pressure is sufficient to raise the water 60 feet. The volume is 100 gallons a minute and the quality fairly soft. The following record is supplied by the driller:

Record of Durst artesian well south of Belle Fourche.

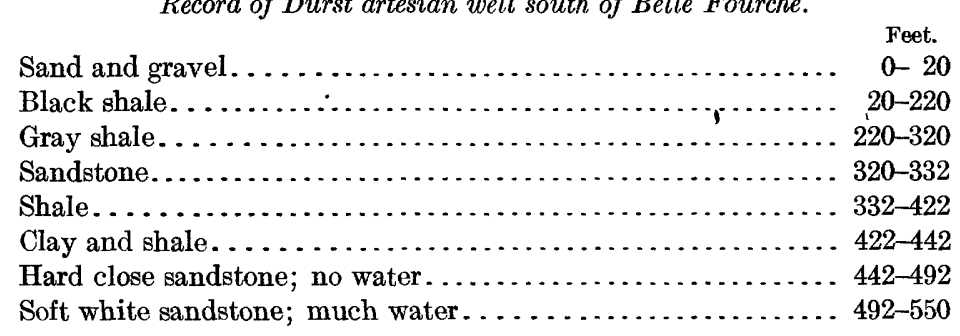

Two wells on the Case ranch, a mile farther south, have depths of 241 and 355 feet and yield good flows of soft water. The deeper well shows a pressure of 26 pounds.

Another shallow well just south of Minnesela, with a depth of 381 feet, has a 2-gallon flow of soft water under a pressure of 30 pounds.

United States Reclamation Service wells.-The United States Reclamation Service has drilled two artesian wells in connection with the Belle Fourche project, one at the dam site on Owl Creek, in the SE. $\frac{1}{4}$ SE. $\frac{1}{4}$ sec. 18 , T. 9 N., R. 4 E., and the other at the intake of the diversion canal $1 \frac{1}{2}$ miles below Belle Fourche. The well at the dam site 
is 1,380 feet deep, and has a 1-gallon flow under pressure sufficient to raise the water 20 feet or more. The boring was in Carlile and Graneros shales, with hard streaks at $250,540,640,790,900$, and 1,330 feet, that at 250 feet probably representing a portion of the Greenhorn limestone. The Dakota sandstone was entered near the bottom; so the well is supplied by the first flow.

The well at the intake of the diversion canal is on the north bank of Belle Fourche River, in the SE. $\frac{1}{4}$ sec. 36, T. 9 N., R. 2 E. It is 627 feet deep and 2 inches in diameter, and obtains its supply from a depth of 625 feet. A first flow was found in the Dakota sandstone at a depth of 567 feet. Shale (Fuson) separates the two flows. The following is an analysis of the water:

Analysis of water from artesian well at intake $1 \frac{1}{2}$ miles below Belle Fourche.

\begin{tabular}{|c|c|c|}
\hline & [By F. M. Eaton.] & $\begin{array}{c}\text { Parts } \\
\text { per } 100,000\end{array}$ \\
\hline Ca... & & 0.97 \\
\hline Mg. . & & .24 \\
\hline & & 15.37 \\
\hline so. & & 14.09 \\
\hline $\mathrm{Cl} \ldots$ & & 1.62 \\
\hline $\mathrm{HCO}_{3}$ - & & 22.20 \\
\hline $\mathrm{CO}_{3} \ldots$ & & $\begin{array}{cc}.59 \\
.001\end{array}$ \\
\hline
\end{tabular}

Orman well.-The Orman well is situated in the NE. $\frac{1}{4}$ SW. $\frac{1}{4}$ sec. 19, T. 9 N., R. 4 E., at the south end of the Owl Creek dam. It was finished in October, 1906. The diameter is 3 inches and the depth 1,417 feet. The water-bearing bed was entered at a depth of 1,325 feet and is a very coarse sandstone 40 feet thick. The flow at an altitude of 3,017 feet, or 18 feet above the ground, is 50 gallons a minute, and 26 feet higher it is 32 gallons. The temperature is $94^{\circ}$. Another well 6 inches in diameter is now being drilled on ground 45 feet higher a few rods farther south, and in May, 1907, it had reached a depth of 1,100 feet. An analysis of the water from the 3 -inch well is as follows:

Analysis of water from well at Orman.

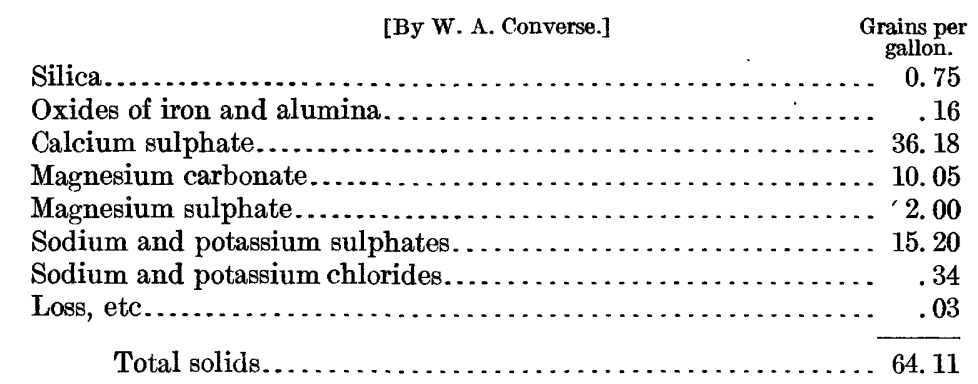

Free ammonia, 0.02 ; albuminoid ammonia, 0.01 part per million. No nitrogen as nitrates or nitrites. Chlorine as chlorides, 3.54; oxygen consumed, 3.50 parts per million, 
Chambers ranch.-On the Chambers ranch, in the SW. $\frac{1}{4}$ NW. $\frac{1}{4}$ sec. 8 , T. 8 N., R. 1 E., on the hogback ridge 9 miles west of Belle Fourche, a boring was sunk in 1899 to a depth of 700 feet. It obtained no flow and was finally abandoned. The following record is given:

Record of boring on Charnbers ranch 9 miles west of Belle Fourche.

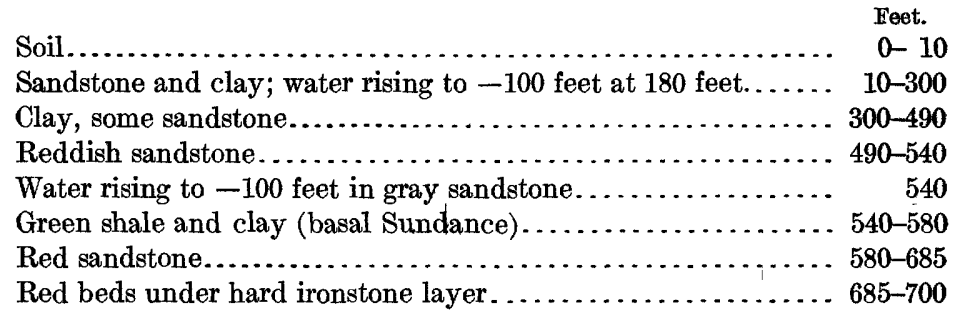

The boring began at the top of the Dakota sandstone and penetrated that formation and the underlying Fuson and Lakota beds within the first 200 feet. The water at a depth of 180 feet was in the Lakota sandstone, which affords the large flows in the valleys about Belle Fourche, but the boring was on land over 100 feet too high for a flow. The reddish sandstone at a depth of 490 to 540 feet was in the Sundance formation, and the water at 540 feet was in the sandstone near the lower portion of the Sundance. The Spearfish red beds were entered at a depth of 580 feet and penetrated for 120 feet.

Vale.-In March, 1909, Mr. H. H. Stearns reached a depth of 2,215 feet with a boring for gas. Near the bottom Dakota sandstone was penetrated, underlain by a thin coal layer, 25 feet of soapstone, and 15 feet of white and blue mud and red chalky clay.

\section{CAMPBELL COUNTY.}

Campbell County lies mainly on the high plateau on the east side of the Missouri Valley, but it extends to Missouri River, along which it includes a narrow belt of lower lands. The higher ridges are underlain by thick deposits of glacial drift lying on a thick mass of Pierre shale, but in some of the higher areas thin deposits of sandy beds intervene. The shales outcrop lextensively along the river bank. The county is undoubtedly underlain by the Dakota sandstone at depths ranging from 1,400 feet in the southwest corner of the county to 2,000 feet or more in the higher portions. No wells are reported in this county, but the records of wells in adjoining counties indicate that flows may be expected up to an altitude of about 1,900 feet.

$70214-$ IRR $227-09-6$ 


\section{CHARLES MIX COUNTY.}

Charles Mix County extends along the east bank of the Missouri River for 75 miles or more and onto the $\mathrm{is} h \mathrm{~h}$ plins to the northeast. These plains are elevated about 300 feet above the : - -or and have some ridges upon them which rise considerably hiy:. 'T ite hich lands are covered by drift, but along the river banks and in so in of the valleys the Niobrara chalkstone appears, overlain by Pierre shale. The Dakota sandstone underlies the county and is the source of water in numerous wells. Artesian flows are available in all but the very highest lands, there being one small nonflowing area west of Geddes and another on the morainal hills south of Wagner; possibly there are a few other localities too high for flows. Wells are most numerous on the plains in the northern townships; others are sunk at intervals along the river bottom and in some of the southeastern townships. The following nearly complete list includes all wells from which returns have been received:

Artesian wells in Charles Mix County.

\begin{tabular}{|c|c|c|c|c|}
\hline $\begin{array}{l}\text { Town- } \\
\text { ship. }\end{array}$ & Range. & Depth. & $\begin{array}{l}\text { Average } \\
\text { yield per } \\
\text { minute. }\end{array}$ & Remarks. \\
\hline $\begin{array}{r}94 \\
95 \\
95 \\
95 \\
96 \\
96 \\
96 \\
96 \\
96 \\
96 \\
97 \\
97 \\
97 \\
98 \\
98 \\
98 \\
98 \\
98 \\
98 \\
98 \\
99 \\
99 \\
99 \\
99 \\
99 \\
100 \\
100 \\
100 \\
100 \\
100\end{array}$ & $\begin{array}{l}64 \\
63 \\
64 \\
65 \\
62 \\
63 \\
64 \\
65 \\
67 \\
68 \\
63 \\
66 \\
67 \\
64 \\
65 \\
66 \\
67 \\
68 \\
68 \\
68 \\
69 \\
66 \\
67 \\
68 \\
69 \\
70 \\
67 \\
68 \\
69 \\
70 \\
71\end{array}$ & $\begin{array}{r}\text { Feet. } \\
651 \\
795 \\
1,020 \\
730 \\
150 \\
151 \\
144 \\
775 \frac{1}{2}, 802 \\
266 \\
810 \\
150 \\
800-905 \\
700-900 \\
772 \\
920-940 \\
820-950 \\
800-991 \\
\\
800-1,110 \\
1,220 \\
644 \\
840 \\
730-950 \\
720-1,006 \\
944,966 \\
840-1,000 \\
734-875 \\
720-930 \\
856-1,030 \\
890,900 \\
688-868\end{array}$ & 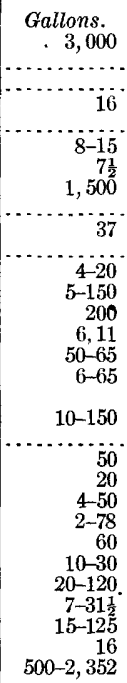 & $\begin{array}{l}\text { Pressure } 5 \text { pounds. } \\
\text { Pressure } 52 \text { pounds. } \\
\text { Pressure } 2 \text { to } 8 \text { pounds. } \\
\text { Pressure } 24 \text { to } 30 \text { pounds. } \\
\text { Various pressures are reported, the greatest being } 63 \\
\text { pounds. } \\
\text { Pressure } 3 \text { to } 80 \text { pounds. } \\
\text { Sec. } 14 \text {; no flow. } \\
\text { Pressure } 24+\text { pounds. } \\
\text { Do. } \\
\text { Greatest pressure reported, } 50 \text { pounds. } \\
\text { Greatest pressure reported, } 40 \text { pounds. } \\
\text { Pressure, } 50 \text { pounds. } \\
\text { Pressures } 20 \text { to } 26 \text { pounds. } \\
\text { Greatest pressure reported, } 87 \text { pounds. } \\
\text { Greatest pressure reported, } 13 \text { pounds. } \\
\text { Pressure in one well, } 15 \text { pounds. } \\
\text { Pressure } 30 \text { pounds. }\end{array}$ \\
\hline
\end{tabular}

The materials penetrated in wells in this county vary considerably. On the higher lands they consist of more or less drift and Pierre shale, underlain by chalk rock, and this in turn by the Benton group, with layers of sandstone and limestone. The Dakota sandstone is usually entered for some distance to obtain a sufficiently large volume of 
water and on the higher lands for increased pressure. The following is the record of well No. 2, sunk by the Government, at Lake Andes:

Record of well No. 2 at Lake Andes, Charles Mix County.

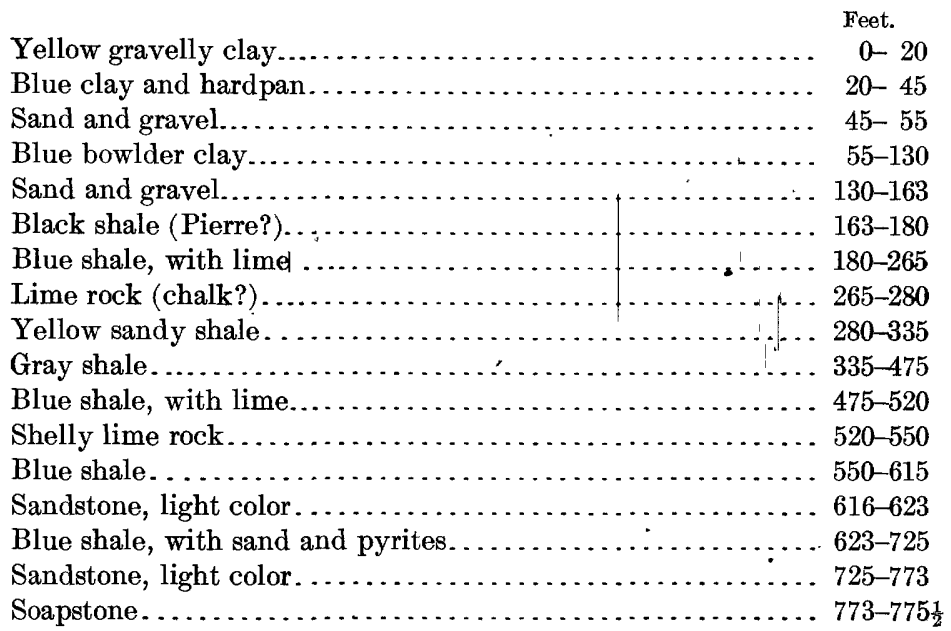

The sandy beds that lie a short distance below the supposed chalk probably represent the sandstone member which is persistent under a wide area in southeastern South Dakota. The layers of lime rock which extend from 520 to 550 feet represent the Greenhorn limestone horizon in the Benton group. The precise boundary between the Benton and Dakota is difficult to discern in the record as given, but probably it is at a depth of 725 feet, the sandstone extending from this depth to 773 feet and yielding a 1,500-gallon flow of water.

The following record is given for the well at the Yankton Agency:

Record of well at Yankton Agency, Greenwood, Charles Mix County.

\begin{tabular}{|c|c|}
\hline & $\begin{array}{l}\text { Feet. } \\
0-1\end{array}$ \\
\hline Yellow sandy clay. & $1-25$ \\
\hline Gray shale........ & $25-44$ \\
\hline Blue shale . . . . . . . . . . . . . . & $44-75$ \\
\hline Blue shale, with chalk and gravel. . & $75-91$ \\
\hline Yellow sand and gravel.... & $91-114$ \\
\hline Gray rock............ & $114-117$ \\
\hline Gray shale. ............. & $117-123$ \\
\hline Gray limestone and pyrites....... & $123-144$ \\
\hline Sandy shale and sand $\ldots \ldots \ldots \ldots \ldots$ & 144-178 \\
\hline Much water, which rises to -65 feet. & $144-178$ \\
\hline Blue shale $\ldots \ldots \ldots \ldots \ldots \ldots \ldots$ & 178-199 \\
\hline Black shale, with pyrites and shells. & $199-275$ \\
\hline Blue shale, tough................ & $275-380$ \\
\hline ack shale, with pyri & $380-420$ \\
\hline
\end{tabular}




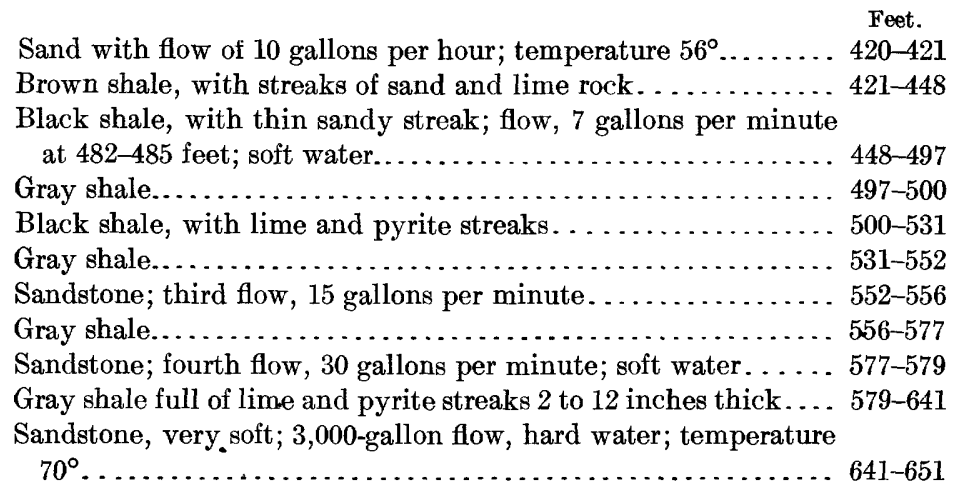

\section{CHEYENNE INDIAN RESERVATION.}

The Cheyenne Indian Reservation lies in north-central South Dakota, north of Cheyenne River, between Missouri River and longitude $102^{\circ}$. It comprises the deep valleys of Cheyenne, Missouri, and Owl rivers, together with Fox Ridge and the range of high hills north of Owl River, thus covering a region having considerable diversity of topography and a range of more than a thousand feet in altitude. The high ridges are capped by Fox Hills sandstone and to the west by the overlying lignitic formation; the valleys are excavated deeply in Pierre shale. This shale has a thickness of about 1,000 feet, as nearly as could be ascertained, and is underlain by a regular succession of Niobrara and Benton shales and Dakota sandstone. The Dakota has been reached at the Cheyenne Agency at a depth of 1,317 feet and found to contain a large volume of water500 gallons per minute-under a pressure of 205 pounds to the square inch. As the mouth of the well is at an altitude of about 1,500 feet above sea level, the pressure indicates a head of 1,970 feet - sufficient to afford a flow far up the slopes of the high ridges in the central and northern parts of the reservation and throughout the valleys. As the hydraulic gradient rises to the west toward the Black Hills, the altitude at which flows are obtainable and the pressures in the lowlands both gradually increase also in that direction.

Owing to the slight westerly dip of the formations and the rise in the land the Dakota sandstone doubtless lies much deeper in the western portion of the reservation than at Cheyenne Agency. On Cheyenne River, at the west border of the reservation, its depth is probably nearly 2,000 feet. On Owl River, which is in a somewhat higher valley, it is estimated to be at a depth of at least 2,200 feet.

The well at the Cheyenne Agency is in the Missouri Valley, on a terrace about 40 feet above the river. The flow was found at a 
depth of 1,317 feet, under a cap rock 1 foot thick. The pressure when the well was first closed was 187 pounds, but the amount increased to a maximum of 205 pounds in four days. The well contains 530 feet of 8-inch casing, 1,015 feet of 6-inch casing, and 1,337 feet of 4-inch casing. The water has a temperature of $79^{\circ}$ or $80^{\circ}$, is similar in salinity to that at Pierre, and also contains much illuminating gas, which was encountered by the 8 -inch casing and amounts to about 3,400 cubic feet per day. The log of the boring, kindly furnished by A. E. Swan, is as follows:

Record of artesian well at Cheyenne Agency, Cheyenne Indian Reservation.

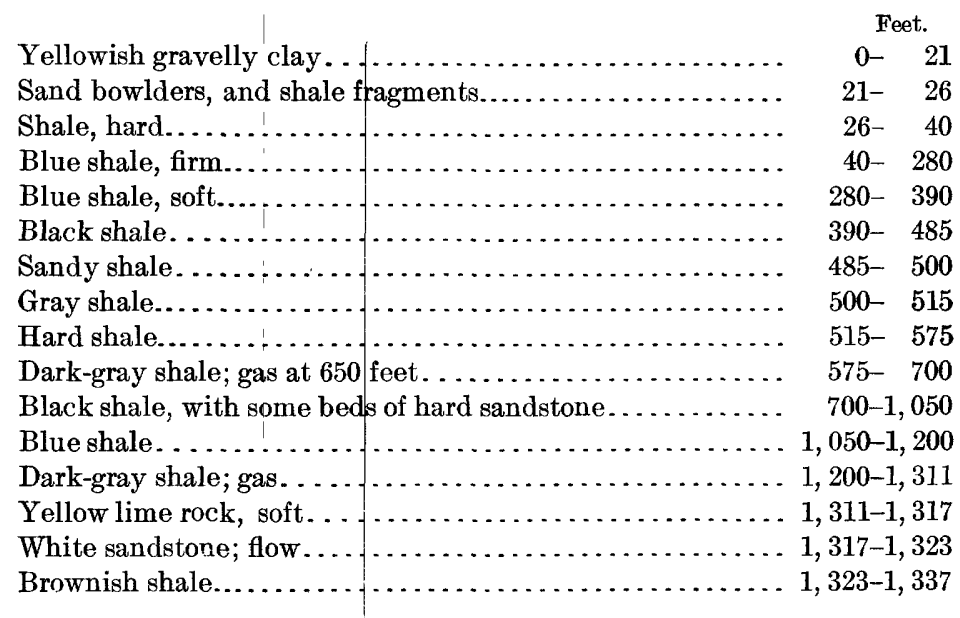

Although the water of this well is somewhat saline, the boring is to be regarded as a great success. The pressure is phenomenal and could, if necessary, be utilized for running a large amount of machinery.

\section{CLARK COUNTY.}

Clark County extends from the east margin of the James River plain far up the western slope of the east coteau, having a range in altitude from about 1,400 feet to 1,800 feet.

Raymond.-The first flowing well bored in the county was on the farm of Bohri Brothers, in the SE. $\frac{1}{4}$ sec. 22, T. 117 N., R. 59 E., about $1 \frac{1}{2}$ miles northeast of Raymond, at an altitude of about 1,490 feet. The total depth of the boring was 1,200 feet, but the casing extended only to 1,075 feet. The diameter of the casing was 6 inches, and the lower 40 feet were perforated. Flows were found in sands from 1,005 to 1,025 feet and from 1,050 to 1,053 feet. The well was finished in the spring of 1892, and the water continued to flow with a closed pressure of 80 pounds until the winter of 1893, when the 
casing became clogged up and the flow diminished to a small drip. The log of the boring is as follows:

\begin{tabular}{|c|c|}
\hline Yellow clay.. & $\begin{array}{l}\text { Feet. } \\
0-\quad 37\end{array}$ \\
\hline & $37-\quad 66$ \\
\hline und, gravel, and clay $\ldots \ldots \ldots \ldots \ldots \ldots \ldots$ & $66-\quad 80$ \\
\hline 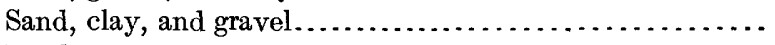 & $80-100$ \\
\hline${ }^{\prime}$ & $100-126$ \\
\hline$\ldots \ldots \ldots \ldots \ldots \ldots$ & $126-184$ \\
\hline Blue shale...$\ldots \ldots \ldots \ldots \ldots$ & $184-194$ \\
\hline Slate & $194-\quad 199$ \\
\hline Blue & $199-\quad 279$ \\
\hline .......... & $279-\quad 344$ \\
\hline 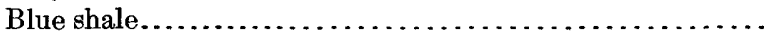 & $344-434$ \\
\hline n shale $\ldots \ldots . \ldots \ldots \ldots \ldots \ldots \ldots \ldots \ldots \ldots$ & $434-524$ \\
\hline ale, with thin layer of sand rock and shale......... & $524-1,005$ \\
\hline ith flow $\ldots \ldots \ldots \ldots \ldots \ldots \ldots \ldots \ldots \ldots \ldots \ldots \ldots \ldots$ & $1,005-1,025$ \\
\hline vith thin layer of sand containing small flow.... & $1,025-1,053$ \\
\hline & $1,053-1,143$ \\
\hline & $1,143-1,198$ \\
\hline Hard rock... & 1,200 \\
\hline
\end{tabular}

The water-bearing bed is in the top of the Dakota sandstone, and probably is the same as the one which supplies the Doland, Andover, Conde, Groton, Turton, and many other wells. This flow is obtainable all along the western margin of the county up to altitudes of 1,600 feet.

Several wells near Raymond obtain flows at 1,013 to 1,075 feet, and several in the southwest corner of the county, averaging from 1,000 to 1,040 feet, have moderately large flows under considerable pressure.

Clark.-Two attempts have been made to obtain the artesian waters at the village of Clark, but in both the tools were lost at a depth of about 1,200 feet and the borings were abandoned. The water-bearing beds probably lie at a depth of about 1,300 feet at Clark, but the head is not sufficient for a surface flow at that locality. No doubt a well to this depth would obtain a large volume of water which would rise within about 110 feet of the surface and afford very satisfactory force-pump wells.

\section{CLAY COUNTY.}

Clay County lies in the valleys of James and Missouri rivers near the southeast corner of South Dakota. Its surface is mostly covered by glacial and alluvial deposits, but the underlying formationsNiobrara chalkstone in the higher lands and Benton shales in the lower valleys to the south-appear here and there. The Dakota 
sandstone lies at a moderate depth below the surface- -600 feet in the northwest corner of the county and about 200 feet in its southeast corner, the beds rising gradually to the southeast.

The sandstone contains water throughout the county, but, owing to the diminution of head toward the southeast, flows are obtainable only in the lower lands. The flow area comprises the southwest quarter of the county, the valley of Vermilion River and its larger branches, and the lowest lands of the Missouri Valley below the mouth of Vermilion River. In this area there are many flowing wells, mostly from 250 to 500 feet in depth, which yield large supplies of excellent water. Most of the wells are small and many obtain their water from the top of the Dakota sandstone. Some first flows are also obtained from sandstone near the bottom of the Benton group. The following is a list of the wells in Clay County:

Artesian wells in Clay County.

\begin{tabular}{|c|c|c|c|c|}
\hline $\begin{array}{l}\text { Town- } \\
\text { ship. }\end{array}$ & Range. & Depth. & $\begin{array}{l}\text { Yield per } \\
\text { minute. }\end{array}$ & Remarks. \\
\hline $\begin{array}{l}\mathbf{9 1} \\
\mathbf{9 2} \\
92 \\
92 \\
\\
93 \\
93 \\
93 \\
\mathbf{9 4} \\
\\
\mathbf{9 4} \\
\mathbf{9 5}\end{array}$ & $\begin{array}{l}51 \\
51 \\
52 \\
53 \\
\\
51 \\
52 \\
53 \\
52 \\
\\
53 \\
52\end{array}$ & $\begin{array}{l}\text { Feet. } \\
210-280 \\
300-400 \\
289-507 \\
205-367 \\
\\
312-410 \\
243-400 \\
240-367 \\
400 \\
402 \\
260-500 \\
260-507\end{array}$ & $\begin{array}{r}\text { Gallons. } \\
6-20 \\
6-90 \\
2-200 \\
2-25 \\
1-20 \\
4-20 \\
11-150 \\
1 \frac{1}{4} \\
5 \\
\text { Few. } \\
1-3\end{array}$ & $\begin{array}{l}\text { Water usually rises a few feet above the surface. } \\
\text { Water rises } 20 \text { feet above some wells. } \\
\text { Some chalk penetrated. One } 35 \text {-pound and one } 20 \text {-pound } \\
\text { pressure reported. } \\
\text { Pressure in one well } 4 \text { pounds. } \\
\text { Pressure } 15 \text { pounds. } \\
\text { Pressure } 6 \text { to } 40 \text { pounds; one well contains alkaline water. } \\
\text { Some irony water. } \\
\text { Alkaline water in one well; pressure } 8 \text { pounds. }\end{array}$ \\
\hline
\end{tabular}

\section{CODINGTON COUNTY.}

Codington County is on the summit of the east coteau, at an elevation varying from 1,700 to over 1,900 feet. At the surface is a thick mass of glacial drift lying on many hundred feet of Pierre shale. The county is underlain by Dakota sandstone, which is doubtless water bearing, but has a head only sufficient to cause the water to rise to about 1,650 feet above sea level, so that no flows are to be expected. The sandstone lies at a depth of about 1,100 feet at Watertown and correspondingly deeper in the highlands of the surrounding hills; as it slopes downward to the west it lies deeper in that direction also.

\section{CUSTER COUNTY.}

All the rocks from the Algonkian granites and schists to the Pierre shale and White River group outcrop within Custer County, - which extends across the greater part of the Black Hills uplift and eastward to Cheyenne River. There are many running streams 
in the higher lands within its borders, but in the lower regions to the east and southwest increased water supplies are greatly needed. On the east side of the crystalline-rock area the formations dip steeply to the east and pass beneath the surface in rapid succession, the Dakkota and associated sandstones reaching a depth of 2,600 feet under the higher lands in the eastern part of the county. The top of the Dakota sandstone reaches a depth of 500 feet within about a mile from the foot of the hogback range and descends at about the same rate for the next 5 miles. Farther east the dip gradually diminishes, until in the extreme eastern part of the county the beds lie nearly level. At Hermosa the depth to the top of the sandstone is probably not more than 600 feet; at Fairburn it is about 900 feet. Along the lower portions of Spring, Battle, and French creeks the Dakota sandstone probably lies at about 2,300 to 2,500 feet below the surface, and correspondingly deeper in the higher lands of the intervening divides. Along Cheyenne River the depth probably averages from 2,200 to 2,400 feet. These calculations are based on estimates of the thickness of the Benton group (about 1,300 feet) and of the Niobrara formation (about 200 feet), and on the occurrence of the tepee butte zone in the Pierre shale, apparently at a horizon of about 1,000 feet above the base of that formation. It is probable that flowing water could be obtained throughout the lower lands east of the hogback range, but not on the divides. In the southwest corner of the county a small area underlain by Dakota sandstone may be expected to yield flowing wells, as indicated by the 550-foot flowing well at Argentine, in the adjoining county to the south.

It is possible that underground waters may be found under the Red Valley in this county, in the Minnelusa sandstone or in the underlying Pahasapa limestone and Deadwood sandstone. These formations have not yet been explored for water in this district, but may prove to be important sources of supply here, as at Cambria,Wyo., a short distance northwest. The unsatisfactory results of the boring at Minnekahta Junction are discouraging as to the prospects for water in these formations to the southeast, although that boring did not test the question conclusively, as it apparently did not reach the Deadwood sandstone. It is thought that this sandstone lies at a depth of about 1,000 feet along the center of the Red Valley, the amount slightly increasing toward the hogback range and decreasing toward the Minnekahta limestone outcrop.

At Buffalo Gap two attempts were made to reach the Dakota sandstone. Both borings were slightly more than 700 feet in depth, entirely in the Benton shale. One was on the crest of a low ridge in 
the western part of the town, and the other was on the lower land on the main street. As the latter began in the middle of the Carlile shale, it would probably have reached the Dakota sandstone within the next 500 feet and have obtained a flow, although the altitude of the surface is just about at the limit to which the water should be expected to rise in this vicinity.

\section{DAVISON COUNTY.}

Davison County lies entirely in the James River valley, near the eastern margin of the Dakota artesian basin. Owing to the uplift of the formations the water-bearing beds are near the surface in a portion of the county, and the waters have been extensively developed by many wells, mostly of moderate depth. In the region south of Mitchell the underground ridge of Sioux quartzite has considerable prominence, its slopes intercepting the Dakota sandstone, so that in several townships the waters from the latter are not available. This is the case south and southwest of Mitchell for several miles, although in a portion of the area sandstones in the Benton group overlap the quartzite and yield flowing wells, in which, however, the pressure is sufficient to afford flow only in the lower lands. Several wells in this district have been bored to the "bed rock," and although some of them have obtained water, they have not had sufficient head to afford a flow. In the northern, western, and southern portions of the county there are wells in nearly every section, most of which find water supplies at less than 500 feet below the surface. Some obtain flows from the sandstone underlying the chalk, others from sandstones low in the Benton group, but most of them have penetrated to the top of the Dakota sandstone. In the southwest corner of the county the land rises considerably and the sandstone dips toward the southeast, so that the depth to the Dakota water rapidly increases. In the extreme southwestern portion of the county the depth of this horizon is between 750 and 800 feet below the surface, and in the valley of Enemy Creek between 350 and 450 feet. About Mount Vernon many wells obtain water, apparently from the Dakota sandstone, at depths from 300 to 420 feet in greater part, most of them also finding upper flows in sandstones of the Benton group. Half way between Mount Vernon and Mitchell there is an area of considerable size in which the Dakota sandstone reaches its maximum uplift and affords flows in wells from 250 to 300 feet deep. On Firesteel Creek and along James River the sandstone is also reached by wells from 200 to 300 feet in depth. In the northern portion of the county the Dakota sandstone dips to the north and the depths increase, but only to 460 feet in the 
extreme northwest corner. The following is a list of the principal borings in the different townships of Davison County:

Artesian wells in Davison County.

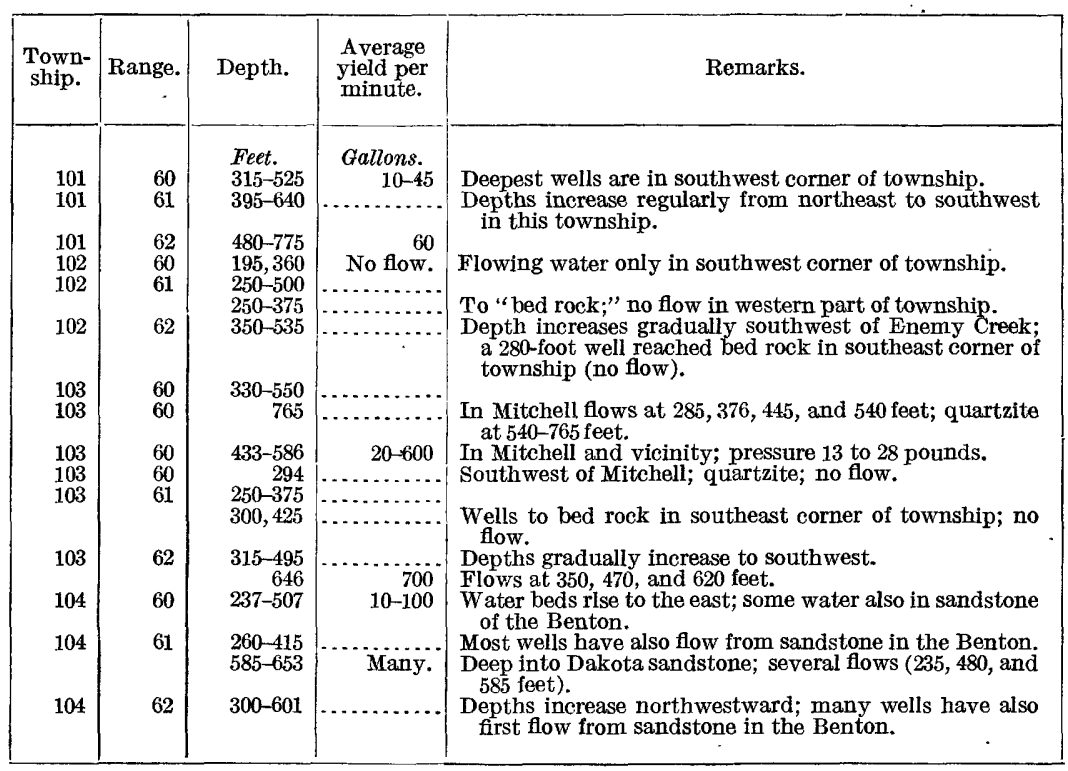

\section{DAY COUNTY.}

Day County lies mainly on the high coteau, but extends westward to the plain of the James River valley. The coteau consists of a high ridge of glacial deposits underlain by a great thickness of Pierre shale. The Dakota sandstone underlies the entire county, having a depth of about a thousand feet at Andover, but being very much deeper under the highlands to the east. It appears to dip gently to the west, judging from its difference in altitude in the well at Milbank and at other places in the James River valley. The formation is undoubtedly water bearing throughout, but as the maximum head of the water is only about 1,680 feet and the land on the summit of the coteau has an elevation of 1,750 to 1,900 feet, flowing wells are not obtainable far east of Andover. There are several successful wells in the vicinity of Pierpoint and at Andover; but on the coteau at Webster, although the Dakota sandstone appears to have been reached, the altitude is too great to afford a flow. A list of the artesian wells in the county follows: 


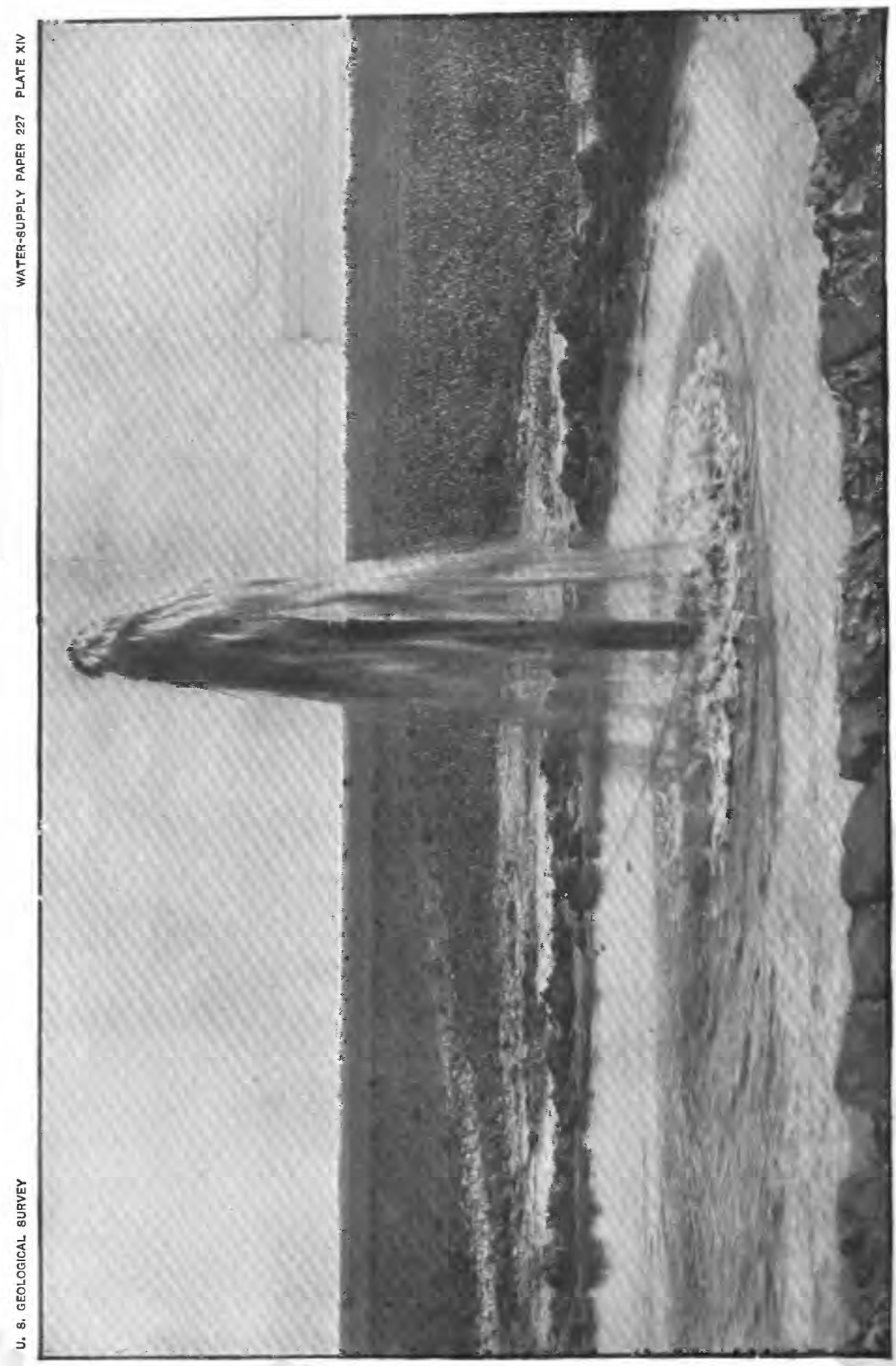

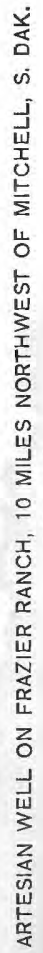



Artesian wells in Day County.

\begin{tabular}{|c|c|c|c|c|}
\hline & Depth. & $\begin{array}{l}\text { Diam- } \\
\text { eter. }\end{array}$ & $\begin{array}{c}\text { Average } \\
\text { yield } \\
\text { per } \\
\text { minute. }\end{array}$ & Remarks. \\
\hline 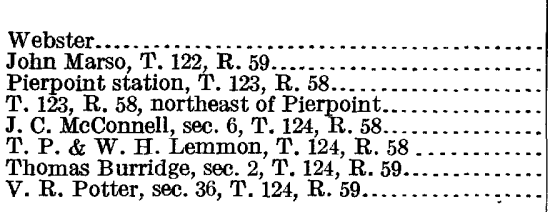 & $\begin{array}{r}\text { Feet. } \\
1,550 \\
1,080 \\
1,240 \\
1,240 \\
930 \\
1,200 \\
930 \\
970\end{array}$ & 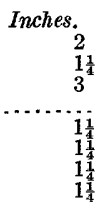 & $\begin{array}{r}\text { Gallons. } \\
40 \\
4 . \\
28 \\
15 \\
40 \\
35\end{array}$ & $\begin{array}{l}\text { Unsuccessful. } \\
\text { Pressure } 85 \text { pounds. } \\
\text { Water just flows. } \\
\text { Pressure } 70 \text { pounds. } \\
\text { Pressure } 40 \text { pounds. } \\
\text { Pressure } 75 \text { pounds. } \\
\text { Pressure } 90 \text { pounds. }\end{array}$ \\
\hline
\end{tabular}

Andover.-The well at Andover has a flow of 300 gallons per minute, a pressure of 90 pounds to the square inch, and a bore of $6 \frac{1}{2}$ inches. Its $\log$ is as follows:

Record of well at Anaover.

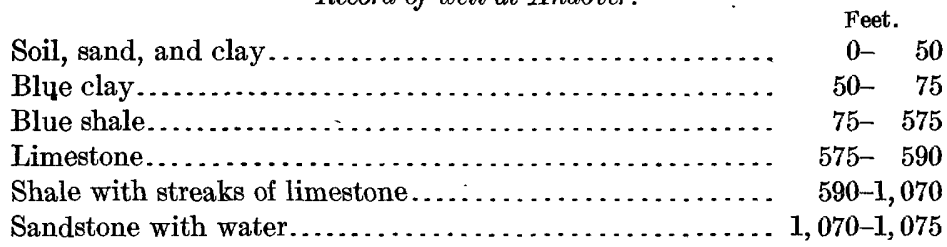

The water contains 150 grains per gallon of saline ingredients, of which 20 grains are chloride of sodium.

Pierpoint.--The Potter well, 2 miles west of Pierpoint, has a depth of 970 feet, a diameter of $1 \frac{1}{4}$ inches, a flow of 35 gallons per minute, and a pressure of 90 pounds to the square inch. The Lemmon well, a short distance east of the village, has a depth of 1,200 feet, a diameter of $1 \frac{1}{4}$ inches, and a 15-gallon flow under 93 pounds pressure. The first flow is at 1,070 feet.

Webster.- It is claimed by some that the boring at Webster reached a depth of 1,550 feet, but others assert that only 1,400 feet was attained. It is also claimed that a small flow was found at 1,100 feet in 1896 . It is improbable that this flow was derived from the Dakota sandstone, for that would indicate a head of 1,840 feet, an amount very much greater than the head in the wells in the James River valley to the west and at Milbank to the east. It is reported that the principal formation underlying the drift was shale, with some beds of pyrites, limestone, and sandstone, and it is also stated that the well penetrated sand supposed to be the Dakota sandstone, which yielded a large amount of water that did not rise to the surface. Some samples of borings submitted are mainly fine sand, but as they are evidently washings from the drillings and no statement is furnished as to their thickness, they throw no light on the stratigraphy. 


\section{DEUEL COUNTY.}

Deuel County lies on the east side of the east coteau, embracing the ridge which lies between Sioux and Minnesota rivers. The altitudes are about 1,600 feet in the southeast corner, 1,800 feet in the center, and 1,300 feet in the northeast corner. The highlands are mantled by glacial drift lying on a thick mass of Pierre shale. The Dakota sandstone underlies the entire county at depths of 500 to 1,200 feet, being nearest the surface in the lowest land in the northeast corner of the county. The formation probably contains water having a head from 1,400 to 1,500 feet, which would yield a flow in the extreme northeast corner of the county. So far as known, no wells have been sunk to test the conditions of the deeper seated underground waters.

\section{DOUGLAS COUNTY.}

Douglas County is on the highlands between the valleys of James and Missouri rivers. It is covered thickly by drift, which is underlain by several hundred feet of Pierre shale. This formation is penetrated by wells which also pass through the Niobrara chalkstone and the Benton shales and sandstones to reach the Dakota sandstone. The latter lies nearly level or has a slight dip to the southeast, but owing to the irregular topography its depth varies considerably.

Most of the wells are between 750 and 1,000 feet in depth and obtain abundant supplies of excellent water, under pressure sufficient to indicate that flows are obtainable in all parts of the county, unless possibly on some of the very highest points in the northwestern and northeastern townships. In the following list are given facts relating to all the wells in this county from which returns have been received:

Artesian wells in Douglas County.

\begin{tabular}{|c|c|c|c|c|}
\hline & Depth. & $\begin{array}{c}\text { Diame- } \\
\text { ter. }\end{array}$ & $\begin{array}{l}\text { Average } \\
\text { yield per } \\
\text { minute. }\end{array}$ & Remarks. \\
\hline 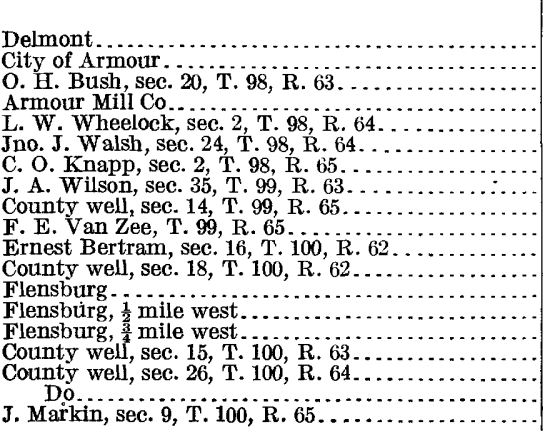 & $\begin{array}{r}\text { Feet. } \\
821 \\
757 \\
722 \\
800 \\
901 \\
736 \\
860 \\
703 \frac{1}{2} \\
925 \\
1,010 \\
600 \\
1,025 \\
611 \\
651 \\
775 \\
750 \\
937 \\
975 \\
80\end{array}$ & $\begin{array}{r}\text { Inches. } \\
2 \\
6 \\
1 \frac{1}{4} \\
8 \\
8-6 \\
2 \\
6 \\
8-6 \\
4 \\
6 \\
2 \\
-2 \\
2 \\
2 \\
2 \\
4 \\
6 \\
4 \\
12\end{array}$ & $\begin{array}{r}\text { Gallons. } \\
60 \\
1,500 \\
\text { Many. } \\
1,500 \\
1,200 \\
20+ \\
900 \\
2,100 \\
600-700 \\
1,000 \\
\text { Many. } \\
1,025 \\
60 \\
\ldots-7-. \\
65-70 \\
600-700 \\
900 \\
1,000 \\
\text { Few. }\end{array}$ & $\begin{array}{l}\text { Pressure } 55 \text { pounds. } \\
\text { Pressure } 64 \text { pounds. } \\
\text { Pressure } 75 \text { pounds. }\end{array}$ \\
\hline
\end{tabular}


Most of the wells appear to draw their supplies from the upper portion of the Dakota sandstone, but others go deeply into it so as to gain additional pressure and volume. The sandstone appears to be 150 feet or more in thickness, lying mostly in one body, but locally there are intercalated masses of shale. It is reported that at the county well in sec. 26, T. 100 N., R. 64 E., the sandstone was entered at 800 feet and was found to be underlain by granite at 937 feet. For the first 60 to 140 feet the wells pass through drift deposits, then through 100 to 200 feet of Pierre shale and 50 to 80 feet of chalk into a bed of the upper sandstone of the Carlile shale which persists over a wide area and yields water to several pumped wells 300 to 450 feet deep. The Benton beneath this sandstone contains Greenhorn limestone in its lower portion, and a few layers of sandstone which at some localities yield slight flows.

\section{EDMUNDS COUNTY.}

Edmunds County extends from the summit of the Bowdle Hills eastward into the James River valley, its altitude ranging from 1,400 to slightly over 2,000 feet. Under a mantle of glacial drift there is a thick mass of Pierre shale and the underlying formations, including several hundred feet of Dakota sandstone. The first deep boring in the county was at Ipswich, where a large volume of water was found at a depth of 1,265 feet under a pressure claimed to have been 120 pounds. In 1891 a pressure of 106 pounds was measured, indicating a head sufficient to raise the water to 1,775 feet above sea level. This is somewhat greater tnan is found in the wells at Aberdeen, just to the east, and 140 feet less than in the well at Shelby. The head is sufficient, however, to afford artesian flows in all the eastern part of the county and probably, from the indication of the Shelby well, as far west as the bas 3 of the Bowdle Hills, some distance west of Roscoe, where the altititude is from 1,900 to over 2,000 feet. The first well at Ipswich did not prove satisfactory and another one, sunk in 1902, obtains a 150-gallon flow from a depth of 1,245 feet. In the summer of 1903 it was reported that there were 83 deep artesian wells in the county, mostly of medium size, but furnishing an abundance of excellent water for farm and stock purposes. Some data in regard to these wells are given in the following table:

Artesian wells in Edmunds County.

\begin{tabular}{|c|c|c|c|c|c|c|c|}
\hline $\begin{array}{l}\text { Town- } \\
\text { ship. }\end{array}$ & Range. & Depth. & $\begin{array}{l}\text { Average } \\
\text { yield per } \\
\text { minute. }\end{array}$ & $\begin{array}{l}\text { Town- } \\
\text { ship. }\end{array}$ & Range. & Depth. & $\begin{array}{c}\text { Average } \\
\text { yield per } \\
\text { minute. }\end{array}$ \\
\hline $\begin{array}{l}121 \\
121 \\
121 \\
121 \\
121 \\
121 \\
122 \\
122 \\
122 \\
122\end{array}$ & $\begin{array}{l}66 \\
67 \\
68 \\
69 \\
70 \\
71 \\
66 \\
67 \\
68 \\
69\end{array}$ & $\begin{array}{r}\text { Feet. } \\
987-1,100 \\
1,025-1,155 \\
1,155-1,250 \\
1,240 \\
1,300-1,370 \\
1,500-1,569 \\
1,000-1,100 \\
1,000-1,190 \\
1,145-1,180 \\
1,305-1,360\end{array}$ & $\begin{array}{r}\text { Gallons. } \\
12-35 \\
20-50 \\
40-50 \\
25 \\
35 \\
20 \\
15-70 \\
5-35 \\
20-35 \\
35-70\end{array}$ & $\begin{array}{l}122 \\
123 \\
123 \\
123 \\
123 \\
123 \\
124 \\
124 \\
124 \\
124\end{array}$ & $\begin{array}{l}71 \\
66 \\
67 \\
68 \\
69 \\
70 \\
66 \\
67 \\
68 \\
69\end{array}$ & $\begin{array}{r}\text { Feet. } \\
1,526 \\
1,075-1,125 \\
1,305-1,360 \\
1,526 \\
1,075-1,125 \\
1,498 \\
1,125-1,148 \\
1,150-1,175 \\
1,225-1,350 \\
1,356\end{array}$ & $\begin{array}{r}\text { Gallons. } \\
2 \\
25 \\
35 \\
97-150 \\
30 \\
3 \frac{1}{2} \\
40-41 \\
35-120 \\
25-45 \\
60\end{array}$ \\
\hline
\end{tabular}


FALI RIVER COUNTY.

Fall River County lies on the south slope of the Black Hills uplift, with the Dakota sandstone and underlying formations outcropping to the west. Cheyenne River cuts a deep valley across the uplift, but is deflected by it considerably to the south. The land presents much variety of configuration, having wide areas of undulating plains to the south and hogbacks of the Dakota sandstone to the north. There is a great diversity of geologic structure and distribution of the formations. To the south are broad areas of the Pierre shale, from under which the regular succession of Niobrara, Benton, Dakota, and underlying formations rise to the north. The general rise of the beds is to the north, but there is a main anticline which extends up Hat Creek valley and pitches beneath Pine Ridge to the south. Another steeper, but less extensive, arch lies east of Maitland, and

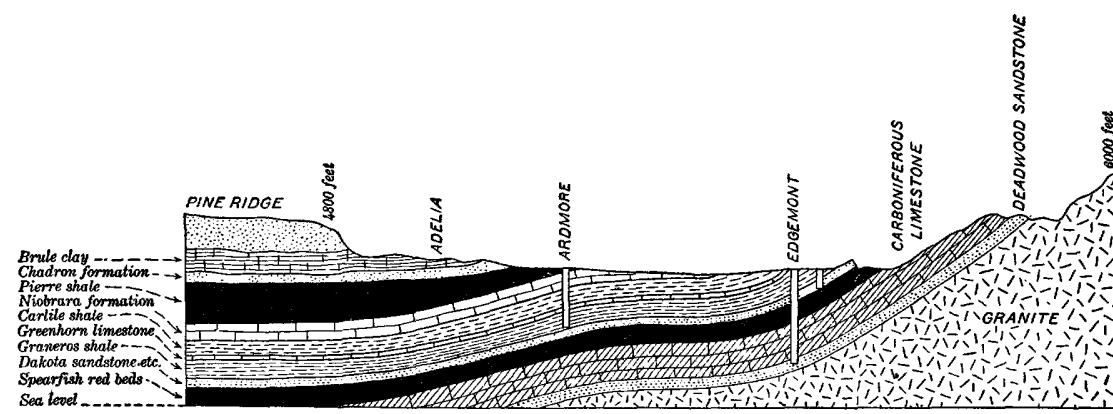

Fig. 5.-Section from the Black Hills to Pine Ridge across Fall River County, showing relations of the water-bearing Dakota and associated sandstones, looking west.

two smaller arches extend southeastward from Edgemont and into the southeast corner of the county from the Pine Ridge Reservation. Between these anticlines are synclines, or basins, which in the vicinity of Oelrichs and farther south hold fully 1,200 feet of the Pierre shale, with the Dakota sandstone more than 2,000 feet beneath the surface. The basin west of Hat Creek is much shallower, the greatest depth of the Dakota sandstone probably not being much more than 2,000 feet on the highlands west of Ardmore. Figure 5 gives a northsouth section across the county.

A number of wells have been sunk in Fall River County, some of which have reached the Dakota sandstone, while others have failed to do so. At Argentine a well in that sandstone yields a flow and at Edgemont some wells obtain water from it which has not sufficient head to flow. It is probable from these results that in all of the county underlain by the Dakota sandstone water supplies may be obtained, though flows can be had only in the extreme northwestern portion, and on the slopes between the hogback and Cheyenne River in the 
northeastern portion. At Minnekahta a deep boring begun in the "Red Beds" penetrated far into the underlying formations, but was unsuccessful. The new 2,980-foot well at Edgemont yields a large flow from the Deadwood sandstone that underlies the entire county.

Edgemont.-In this city and its vicinity a number of wells were sunk several years ago in search of water from the Dakota sandstone. .Nearly all obtained supplies for pumping, but owing to the low altitude of the outcrops of the sandstone a short distance to the east the water does not have sufficient head to flow. The water did not prove satisfactory for use in locomotives, and all but the deeper well at the railroad roundhouse have been abandoned. This well, of which the record is given below, had a depth of 1,125 feet, but is now filled to the depth of 700 feet.

Record of deep well at Edgemont.

\begin{tabular}{|c|c|}
\hline & Feet. \\
\hline Shale............... & $0-295$ \\
\hline Sand, white; water... & $295-\quad 325$ \\
\hline Soft white bed....... & $325-$ \\
\hline 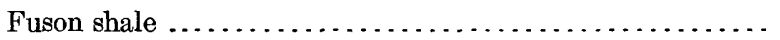 & $350-$ \\
\hline Sandstone, white, with 10 -foot soft white bed at base....... & $430-$ \\
\hline 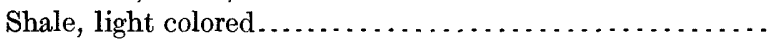 & $455-$ \\
\hline 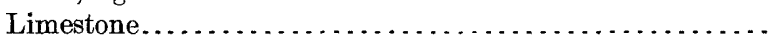 & $497-$ \\
\hline Sandstone, white; water $\ldots \ldots \ldots \ldots \ldots \ldots \ldots \ldots \ldots$ & 509 \\
\hline Sandstone, dark ................. & $604-$ \\
\hline Sandstone, white above, red below ............ & $612-$ \\
\hline th 7 -foot layer of limestone at base................ & $652-$ \\
\hline Shale, light colored & $705-$ \\
\hline 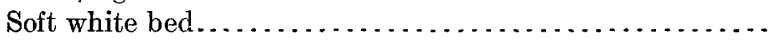 & $752-$ \\
\hline Sundance, upper dark shale......................... & $802-$ \\
\hline 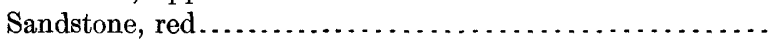 & $957-977$ \\
\hline 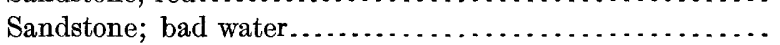 & $977-1,012$ \\
\hline 1 & $1,012-1,125$ \\
\hline
\end{tabular}

Water of bad quality was found in the white sand at 295 feet and in the sandstone at 977 feet. Fairly good water, rising within 60 feet of the surface, is now obtained from the sandstone that begins at 509 feet. It contains 239 grains of solid matter per gallon, of which 9.33 grains are lime. The log appears to be fairly reliable, indicating the Dakota sandstone at 295 to 350 feet; the Fuson formation at 350 to 430 feet; the Lakota sandstone at 430 to about 652 feet; the Morrison shale at 652 to 802 feet; the characteristic red series in the Sundance formation at 957 to 977 feet; the bed of buff sandstone in the Sundance at 977 to 1,012 feet; and the basal dark shales in the Sundance at 1,012 to 1,125 feet. The well at the north end of the $Y$ across the river from Edgemont, has a depth of 960 feet and probably ends in the shales of the Sundance, but the record appears not to be reliable in its details. Some water was found in the white sand at 230 feet and in sandstones at 290 and 430 feet. 
At 578 feet a sandstone begins which yields a good supply of water, rising within 30 feet of the surface. A thin sandstone at 700 feet also yields water, but its volume is small. The record is as follows:

Record of deep boring at the $Y$, near Edgemont.

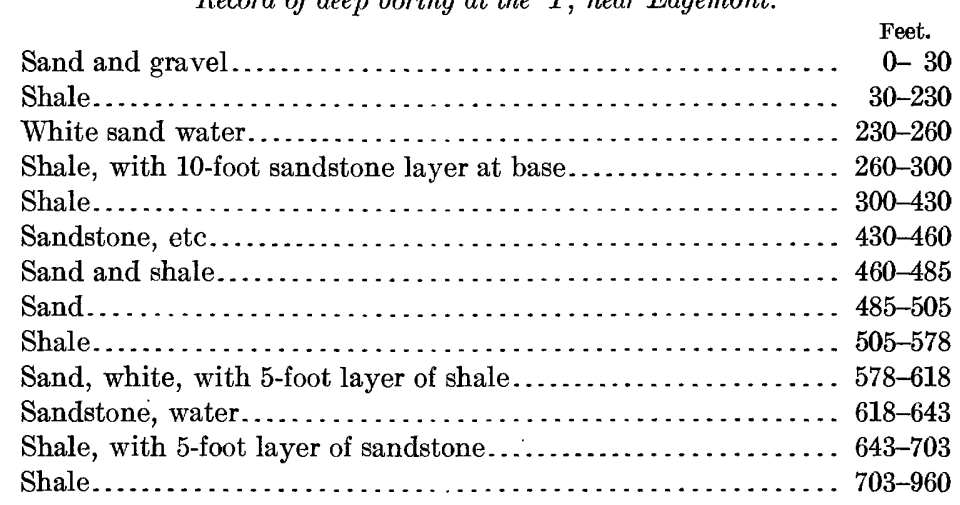

In June, 1905, the Chicago, Burlington and Quincy Railroad Company began a boring intended to go to 3,000 feet if necessary, to test the water resources of the formations below the "Red Beds." In the spring of 1907 a depth of 2,980 feet was reached. A flow found at 2,920 feet finally furnished more than 300 gallons a minute as boring progressed. The pressure is 75 pounds and the temperature $122^{\circ}$. At first the water contained much mineral matter, evidently derived from flows in the red sandstones at higher horizons, for the boring was not cased between 1,850 and 2,111 feet. A 5-inch casing inserted to the latter depth cut off this water, and the main supply was then found to be satisfactory for use in locomotives. The following record is compiled from the log furnished by the company, with slight modifications based on examinations of samples sent by the drillers and others:

Record of artesian well at Edgemont.

\begin{tabular}{|c|c|c|}
\hline Clay. & & 25 \\
\hline 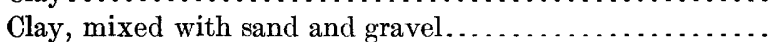 & $25-$ & 33 \\
\hline Drab shale $\ldots \ldots \ldots \ldots \ldots \ldots \ldots \ldots \ldots \ldots \ldots \ldots \ldots \ldots \ldots$ & $33-$ & 35 \\
\hline 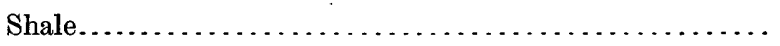 & $35-$ & 90 \\
\hline Sandstone........... & $90-$ & 98 \\
\hline Shale........ & $98-$ & 110 \\
\hline Soft dark shale... & $110-$ & 150 \\
\hline Slate... . . . . . . & $150-$ & 190 \\
\hline 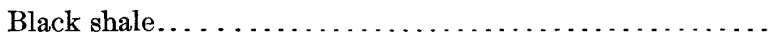 & $190-$ & 269 \\
\hline 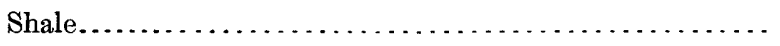 & $269-$ & 297 \\
\hline 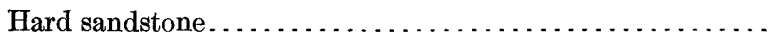 & 297- & 300 \\
\hline White, gray, and black shale $\ldots \ldots \ldots \ldots \ldots \ldots$ & $300-$ & 343 \\
\hline 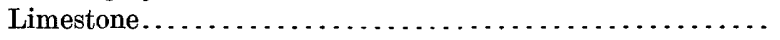 & $343-$ & 347 \\
\hline Pink shale $\ldots \ldots \ldots \ldots \ldots \ldots \ldots \ldots$ & $347-$ & 349 \\
\hline Limestone... . . . . . . . . & $349-$ & 354 \\
\hline
\end{tabular}


White shale.

Feet.

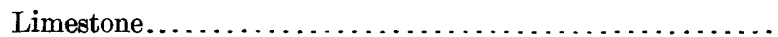

$354-.363$

Red and white sandy clay . . . . . . . . . . . . . . .

$363-371$

Hard dark shale

$371-375$

Hard sandstone.

$375-377$

Dark shale.

$377-398$

Hard sandstone. . . . . . . . . . . . . . . . . . . . . . .

$398-404$

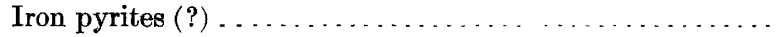

$404-\cdot 407$

Gray shale.

$407-409$

$409-415$

Hard rock. . . . . . . . . . . . . . . . . . . . . . . 417

Shale.................................. 417- 420

Hard limestone............................... $420-431$

Hard sandstone............................ 431- 434

Hard sandstone and dark shale . . . . . . . . . . . . . $440 . .434$

Hard light shale............................... $440-449$

Soft light shale........................... $449-450$

White shale ............................ 450. 456

Soft shale. . . . . . . . . . . . . . . . . . . . . . . 456 . 462

Sandstone................................. 462- 472

Hard limestone................................ 472- 486

Sandstone................................. 486 489

Hard shale................................. $489-493$

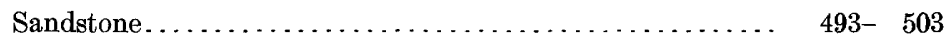

Hard light shale............................ 503- 508

Hard sandy shale. . . . . . . . . . . . . . . . . . . . $50 . \quad 524$

Hard sandstone. . . . . . . . . . . . . . . . . . . . . . . $524-544$

Sandy limestone............................. $544-559$

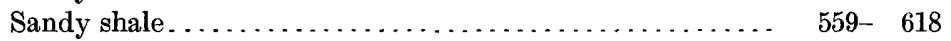

Red sandstone................................ $618-644$

Hard sandy shale............................ $644-669$

Water-bearing sandstone $\ldots \ldots \ldots \ldots \ldots \ldots \ldots \ldots \ldots \ldots .669 .6 \ldots \ldots$

Hard gritty shale . . . . . . . . . . . . . . . . . . . $672-697$

Hard sandy shale. . . . . . . . . . . . . . . . . . . . $697-740$

Soft shelly limestone........................ $740-750$

Limestone.................................. $750-764$

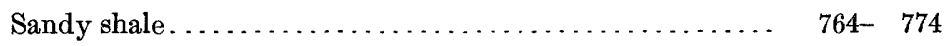

Light sandstone........................... $774-841$

Hard sandy shale. . . . . . . . . . . . . . . . . . . . $841-855$

Blue shale. . . . . . . . . . . . . . . . . . . . . . $855-955$

Sandstone................................ 955- 965

Red gritty shale.......................... $965-1,040$

Hard dark-red sandstone $\ldots \ldots \ldots \ldots \ldots \ldots \ldots \ldots \ldots \ldots . \ldots \ldots$ 1, 040-1,051

White sandy shale......................... 1,051-1,060

Blue shale. . ............................ 1,060-1,080

White sandstone; water rose to surface........... 1,080-1, 098

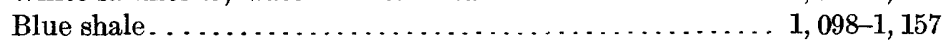

Black hardpan............................. 1, 157-1, 174

White sandstone (some water)................. 1, 174-1, 223

Gray limy shale (black hardpan?) . . . . . . . . . . . . . 1, 223-1, 230

Red shales and sandstones. . . . . . . . . . . . . . . 1,230-1, 850

Red sandstone. . . . . . . . . . . . . . . . . . . 1, 850-1, 955

Limestone, light colored..................... 1; 955-2, 140

70214-IRR 227-09-7 
Feet.

Light brown impure limestone. . . . . . . . . . . . . . . . . 2, 140-2, 198

Red sandstone, very hard and sharp. . . . . . . . . . . 2, 198-2, 203

Red rock (soft and caving first 24 feet)............. 2, 203-2, 278

Red sandstone . . . . . . . . . . . . . . . . . . . . . . . . . 2, 278-2, 292

Limestone... . . . . . . . . . . . . . . . . . . . . . . . . . 2, 29292-2, 303

Red and gray sandstone $\ldots \ldots \ldots \ldots \ldots \ldots \ldots \ldots \ldots \ldots . \ldots . \ldots \ldots$

White limestone, sandy . . . . . . . . . . . . . . . . . 2, 325-2, 352

Sandstone, some lime: reported as limestone. . . . . . 2, 352-2,440

White limestone . . . . . . . . . . . . . . . . . . . . . . 2, 2, 440-2,516

Red sandstone........................... 2, 516-2,537

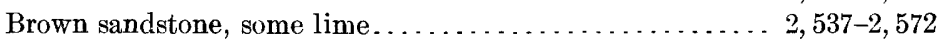

Light-brown sandstone, no lime . . . . . . . . . . . . 2, 2,572-2, 641

Bhack iron pyrites........................ 2, 641-2,648

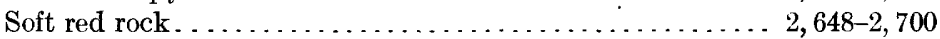

Light-red rock . . . . . . . . . . . . . . . . . . . 2, 2, $700-2,760$

Red rock . . . . . . . . . . . . . . . . . . . . . . . . . 2, 2, 760-2, 878

Sandstone; first flow between 2,920 and 2,948 feet...... 2, 878-2, 890

. $\quad$ Red rock; very hard 6 -inch bed at 2,964 feet . . . . . . . . 2, $890-2,980$

According to another report the beds from 2,203 to 2,648 feet were buff sandstone, and those from 2,648 to 2,658 feet deep-brown sandstone containing much lime.

The identity of some of the rocks given in this record is questionable, especially the so-called limestones, and the limits of the various beds are not by any means accurate. Apparently the Dakota sandstone was reached at a depth of 297 feet, and presumably the base of the Lakota sandstone is the water-bearing sand from 669 to 672 feet. The Morrison and Sundance formations lie next below, with the sandstone in the lower part of the Sundance extending from 1,174 to 1,223 feet. The Spearfish began at 1,230 feet (according to another authority, at 1,255 feet, capped by 15 feet of coarse gray sand) and red beds continued with great uniformity to 1,955 feet, presenting a thickness of more than 700 feet, somewhat more than was expected from the amount in the Red Valley outcrops to the north. It is probable, however, that the Minnekahta limestone was penetrated above 1,955 feet and that the Opeche red sandstone is included in this thickness. Possibly, also, some of the top sandstone of the Minnelusa is included on account of its red color. The identity of the lower beds is difficult to establish. Many feet of the sandstones and limestones are Minnelusa. The base of the Pahasapa (and Englewood) limestones appears to be at the bottom of the thick body of limestone at a depth of 2,516 feet. The beds below this to 2,920 feet are mostly sandstones and shales, largely red, but some of the sandstones are snuff colored and very like the upper part of the Deadwood sandstone. No samples were obtained from the "sands" at 2,920 to 2,980 feet on account of the heavy flow of water. 
As the Deadwood sandstone is less than 100 feet thick in the outcrop zone along the southern side of the Black Hills uplift, it is somewhat unexpected to find a thickness of 462 feet at Edgemont, which would be indicated if the formation begins at a depth of 2,516 feet. It is strongly probable that at 2,980 feet the boring is in the basal Deadwood sandstone near the Algonkian schist and that this sand furnishes the flow. The water passes underground near Pringle at an altitude of nearly 5,000 feet, so that the pressure of 75 pounds at Edgemont (3,440 feet above sea level) is not surprising.

An analysis of the water made for the railroad company ten days after the well was cased is as follows:

Analysis of water from deep artesian well at Edgemont, S. Dak.

\begin{tabular}{|c|c|c|}
\hline & [Hypothetical compounds.] & $\begin{array}{l}\text { Grains per } \\
\text { gallon. }\end{array}$ \\
\hline Sodium chloride... & & 16.19 \\
\hline Sodium carbonate. & $\ldots$ & $\begin{array}{r}.69 \\
\end{array}$ \\
\hline Calcium sulphate. & & .14 .29 \\
\hline Calcium carbonate. & -. & 3.85 \\
\hline Magnesium carbona & ....... & 9.68 \\
\hline Silica and insoluble & & 1.18 \\
\hline
\end{tabular}

Grains per gallon by evaporation, 48.17. The water does not foam in boilers and the solids wash out easily.

Minnekahta.-Several years ago the Burlington and Missouri River Railroad Company made a deep boring at Minnekahta station to obtain a water supply for locomotives. A depth of 1,348 feet is said to have been attained, but no promising amount of water was reported. The record, which is given below, is clearly unreliable and very unsatisfactory for the identification of the geologic formations. No clew is given as to the location of the Minnekahta limestone, which should be expected to begin at about 400 feet below the surface at Minnekahta station. The red sands from 743 to 908 feet are doubtless in the Minnelusa formation, and possibly the red shale at 1,105 feet is the one at its base. At a depth. of 1,348 feet the boring should be near the Deadwood sandstone, for the thickness of the formations from the base of the Sundance through the Pahasapa is not much more than this in the surface exposures in the region to the north. The references to gypsum at various depths in the boring are mistakes as to the identity of the material, except possibly those near the top. It is to be deeply regretted that the record is not more accurate, for it could have thrown important light on the stratigraphy. 
Record of deep boring at Minnekahta.

\begin{tabular}{|c|c|}
\hline & $\begin{array}{l}\text { Feet. } \\
0-\end{array}$ \\
\hline & $0-$ \\
\hline & $12-$ \\
\hline & $47-$ \\
\hline 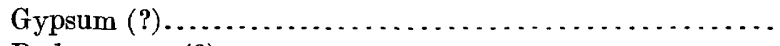 & $62-$ \\
\hline & $107-$ \\
\hline gypsum (?) $\ldots \ldots \ldots \ldots \ldots \ldots \ldots \ldots$ & $173-$ \\
\hline & $308-$ \\
\hline & $378-$ \\
\hline & 388 \\
\hline & $428-$ \\
\hline 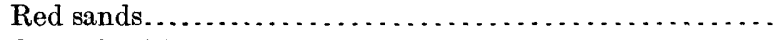 & $443-$ \\
\hline 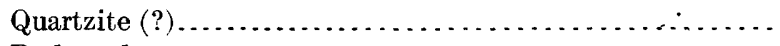 & $523-$ \\
\hline & $538-$ \\
\hline & $558-$ \\
\hline & $581-$ \\
\hline$\ldots \ldots \ldots \ldots \ldots \ldots$ & $611-$ \\
\hline & $643-$ \\
\hline 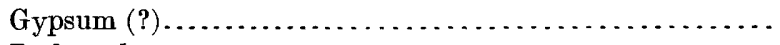 & $663-$ \\
\hline & $743-$ \\
\hline & $908-990$ \\
\hline & $990-1,022$ \\
\hline & $1,022-1,08$ \\
\hline & $1,082-1,10$ \\
\hline & $1,105-1,190$ \\
\hline h 8-foot layer of pyrites (?) $\ldots \ldots \ldots \ldots \ldots$. & $, 190-1,23$ \\
\hline & $1,232-1,28$ \\
\hline & $1,284-1,30^{\prime}$ \\
\hline & $1,307-1,32$ \\
\hline & $325-1$ \\
\hline
\end{tabular}

Ardmore.-At Ardmore, on the Chicago, Burlington and Quincy Railroad, 26 miles south of Edgemont, the railroad company has made a boring to a depth of 1,500 feet without obtaining water. The hole is entirely in shale, except about 40 feet of white sand containing thin partings of black shale. This boring begins about at the surface of the Niobrara formation and apparently penetrates very nearly to the Dakota sandstone, the sandstone bed reported probably being in the Graneros shale. As the altitude of Ardmore is 3,557 feet, and the water-bearing Dakota sandstone outcrops about Edgemont at an altitude of 3,400 feet, there is no possibility of a flow at the former place, but probably a supply of water for pumping could be obtained by slightly deepening the boring into the Dakota sandstone. The estimated altitude to which the water would rise in such a well is about 3,450 feet. The structure here is shown in figure 5 .

Argentine.-This station is a water-tank siding on the Chicago, Burlington and Quincy Railroad, 17 miles northwest of Edgemont. The well is on the south side of Pass Creek. It is a flowing well, 550 
feet deep, yielding a fairly large volume of water, but of a quality not satisfactory for locomotives, as the following analysis shows:

Analysis of artesian water at Argentine.

Sodium sulphate................................. 39.90

Potassium sulphate................................... .90

Lime sulphate...................................... 4.20

Lime carbonate................................... 6.00

Magnesia carbonate................................... 4.00

Alumina and iron oxide............................... .05

Silica............................................. . 19

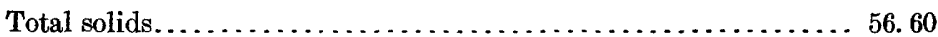

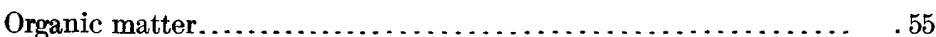

This analysis was kindly furnished by the railroad company. The $\log$ of the boring was not obtainable. The well begins in Graneros shale and undoubtedly obtains its water supply from the Lakota sandstone, which outcrops in the high ridge to the east.

Hot Springs.-At the Soldiers' Home, a short-distance west of Hot Springs, a well was sunk some time ago to a depth of 223 feet. It began just above the top of the Minnekahta limestone, and obtains a moderate water supply from the Minnelusa sandstone.

\section{FAULK COUNTY.}

The geologic relations in Faulk County are almost precisely similar to those in Edmunds County. The western portion of the county lies high on the slopes of the morainal hills of the Bowdle Range, and the eastern portion extends far out on the low level lands of the James River valley. Many wells bored in the county within the last few years indicate that the Dakota sandstone is water bearing throughout and that the waters are under sufficient head to afford flows, except possibly at one or two very high points in the extreme southwest corner. As the strata lie nearly level, dipping very gently toward the west from the vicinity of Faulkton, the depths of the wells increase mainly with the rise of the land, which is slightly higher toward the center of the county. There appears to be considerable variability in the horizon of the principal flow, many of the wells having had to be sunk considerably below the top of the sandstone to obtain water in satisfactory volume: The only reports of pressure which have been received are from the old well at Faulkton, which indicated 25 to 34 pounds per square inch at a time when it was partly clogged up. The old well 4 miles north of east from Orient is reported to have had a pressure of 130 pounds to the square inch before it was clogged, which would indicate a water head of about 1,865 feet above sea level. This well had a depth of about 1,215 feet, a flow of 950 gallons per minute, and a diameter of 6 to 51 inches. Flows were reported in a 
thin bed of lime rock at 394 feet, at 1,070 feet, and at 1,165 feet, where the principal supply was obtained. The materials penetrated are reported to have been as follows:

Record of well in sec. 18, T. 11\%, R. 68, near Orient, Faulk County.

\begin{tabular}{|c|c|}
\hline & Feet. \\
\hline Yellow clay. & \\
\hline 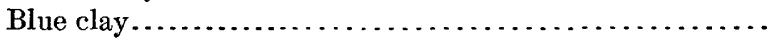 & $20-$ \\
\hline $\begin{array}{l}\text { Shales, black, blue, and gray, with thin layer of lime rock } \\
\text { at base furnishing small flow............................. }\end{array}$ & $47-\quad 394$ \\
\hline 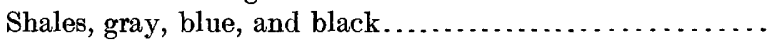 & $394-1,070$ \\
\hline 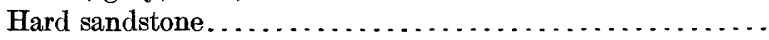 & $1,070-1,110$ \\
\hline Sand, lime, pyrites, and shale... & $1,110-1,165$ \\
\hline Sandstone; 950-gallon flow...... & $1,165-1,215$ \\
\hline
\end{tabular}

A list of artesian wells in the county is given below:

Artesian wells in Faulk County.

\begin{tabular}{|c|c|c|c|c|}
\hline $\begin{array}{l}\text { Town- } \\
\text { ship. }\end{array}$ & Range. & Depth. & $\begin{array}{l}\text { Average } \\
\text { yield per } \\
\text { minute. }\end{array}$ & Remarks. \\
\hline $\begin{array}{l}117 \\
117 \\
117 \\
118 \\
118 \\
118 \\
119 \\
119 \\
119 \\
119 \\
119 \\
120 \\
120 \\
120 \\
120 \\
120 \\
120\end{array}$ & $\begin{array}{l}66 \\
68 \\
69 \\
67 \\
69 \\
70 \\
67 \\
68 \\
69 \\
70 \\
71 \\
67 \\
68 \\
69 \\
70 \\
71 \\
72\end{array}$ & $\begin{array}{r}\text { Feet. } \\
913-1,054 \\
1,095-1,156 \\
1,232 \\
1,016-1,075 \\
1,220-1,466 \\
1,183-1,608 \\
1,030-1,117 \\
1,165 \\
1,206-1,456 \\
1,367-1,402 \\
1,545 \\
1,039-1,060 \\
1,025 \\
1,197-1,287 \\
1,342-1,512 \\
1,505-1,570 \\
1,580-1,650\end{array}$ & $\begin{array}{r}\text { Gatlons. } \\
45-65 \\
90 \\
60 \\
60-75 \\
25-40 \\
45-100 \\
20 \\
150 \\
25-100 \\
100-185 \\
45 \\
50-150 \\
25 \\
10-125 \\
12-100 \\
27-35 \\
30-70\end{array}$ & $\begin{array}{l}\text { First flow at } 850 \text { feet. } \\
\text { Pressure in one well } 60 \text { pounds. }\end{array}$ \\
\hline
\end{tabular}

\section{GRANT COUNTY.}

Grant County lies on the eastern slope of the east coteau, extending from an altitude of over 2,000 feet near Summit to less than 1,000 foet at the foot of Bigstone Lake, in the Minnesota Valley. To the east there is a thick mass of glacial drift constituting the coteau, underlain by the Pierre shale, which extends nearly to the old granites exposed in the vicinity of Bigstone. The Dakota sandstone underlies the greater part of the county and appears to abut against the granite floor as this old rock surface rises to the northeast, but the position of its margin is not known. A boring at Milbank is said to have reached a depth of 303 feet, the lower 20 feet of which was in granite. A thin deposit of water-bearing gravel is reported lying on this rock, containing fossils, and overlain by 200 feet of shale, capped by 75 feet of blue clay that is doubtless of Quaternary 
age. It has been supposed that the basal bed is the Dakota sandstone, but possibly it is in the Benton. A number of other wells in the valley bottom to the west and south yield satisfactory flows at various depths, but the pressure is too low to afford a flow on the upper slopes and summit of the coteau.

The availabie facts concerning the artesian wells of the county are given in the following table:

\begin{tabular}{|c|c|c|c|c|}
\hline · & Depth. & $\begin{array}{c}\text { Diame- } \\
\text { ter. }\end{array}$ & $\begin{array}{l}\text { Average } \\
\text { yield per } \\
\text { minute. }\end{array}$ & Remarks. \\
\hline 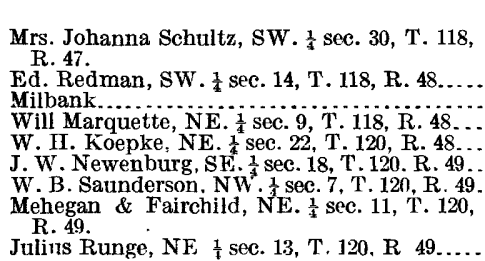 & $\begin{array}{r}\text { Feet. } \\
155 \\
57 \\
303 \\
206 \\
407 \\
422 \\
510 \\
379 \\
\\
459\end{array}$ & \begin{tabular}{r} 
Inches. \\
2 \\
\\
1,2 \\
\hdashline. \\
3 \\
2 \\
2 \\
2 \\
2 \\
2 \\
2
\end{tabular} & $\begin{array}{r}\text { Gallons. } \\
65 \\
40 \\
40 \\
\text { Several. } \\
3 \\
2 \\
10 \\
30 \\
45\end{array}$ & $\begin{array}{l}\text { Water rises-to }+25 \text { feet. } \\
20 \text { feet into granite. } \\
\text { Water rises to }+4 \text { feet. } \\
\text { Water rises to }+36 \text { feet. } \\
\text { Water rises to }+17 \text { feet. } \\
\text { Water rises to }+32 \text { feet. } \\
\text { Water rises to }+2 \text { feet. } \\
\text { Water rises to }+38 \text { feet. }\end{array}$ \\
\hline
\end{tabular}

\section{GREGORY COUNTY.}

Gregory County lies in the southeast corner of the portion of the State west of Missouri River. It extends along the west side of the river for about 50 miles, and comprises the high plateaus extending southwestward to Ponca Creek and beyond. On the river banks and on some of the slopes to the west the Niobrara chalk is exposed, overlain in the highlands by the Pierre shale, which is capped to the south by Tertiary and Quaternary deposits.

The thickness of the Niobrara formation appears to be about 200 feet. It is underlain by 400 feet or more of Benton shales lying on the Dakota sandstone. This sandstone contains artesian water, which has been tapped by a number of wells on Whetstone Creek and by the old well at Fort Randall. The pressure in these wells indicates that the head of the waters along the river is about 1,800 feet to the north and slightly over 1,500 feet to the south and probably increases to 1,850 feet in the southwest corner. This head is sufficient to afford flows only along Missouri and Whetstone valleys and in the lower and middle slopes rising from them to the plateau. It is insufficient to give a flow at Bonesteel, at Fairfax, or in the Ponca Valley.

The depth to the Dakota sandstone averages from 700 to 800 feet along Missouri River, 1,200 feet in the eastern portion of the plateau, and somewhat more than 1,500 feet in the higher lands in the central, western, and southwestern townships. The wells in Whetstone 
Valley are from 714 to 890 feet deep and yield large flows of good water.

The well at Fort Randall, sunk by the Government many years ago, has a depth of 610 feet and is reported to have the following record:

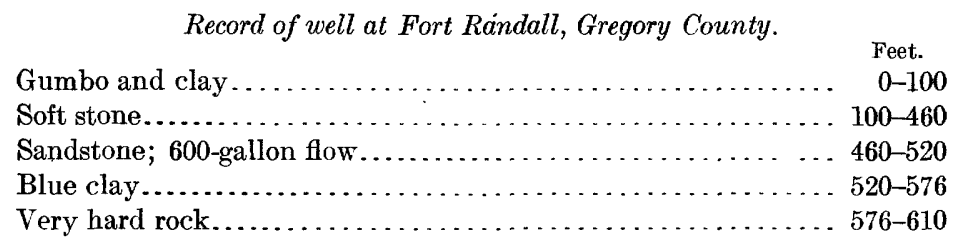

This record is probably very inaccurate, but it appears to indicate that the Dakota sandstone was entered at a depth of 460 feet, or very much nearer the surface than would be expected from the experience of wells on the other side of the river. Possibly the flow is from a sandstone in the Benton group, but the large volume of water is difficult to account for on this supposition. It is claimed that the hard rock in the bottom of the well was granite or quartzite, but this also is very uncertain.

\section{HAMLIN COUNTY.}

Hamlin County is on the summit of the east coteau, between the James and Minnesota river valleys. Its surface consists of a great thickness of glacial drift lying on the Pierre shale. Apparently it is underlain also by the Dakota sandstone at a depth averaging but little more than 1,000 feet throughout. As the altitude of the land is from 1,650 to about 1,900 feet, it is too high for an artesian flow, the probable head of the water in the Dakota sandstone being only about 1,600 feet. So far as known no endeavors have been made to reach the formation.

\section{HAND COUNTY.}

Hand County lies partly on highlands of drift and partly on the lowlands of the James River valley, the former rising to an altitude of somewhat over 2,000 feet in Ree Heights, and the latter having. an average elevation of 1,400 feet. The surface is entirely covered by glacial materials, but these are underlain by a thick mass of Pierre shale and by the usual succession of Niobrara and Benton shales and Dakota sandstone. The Dakota has been reached by numerous wells, which afford flows in the central, northern, and eastern portions of the county. The head of the water averages slightly more than 1,850 feet about Miller and due north, increasing somewhat to the west and decreasing to 1,700 feet in the northeast corner of the county. In the highlands of the southern half of the county the elevation is considerably too great to afford flowing wells, but the 
precise extent of the nonflowing area has not been ascertained. A well 1,611 feet deep, in the NW. $\frac{1}{4}$, sec. 21 , T. 110 N., R. 68 E., is in this area, and although it penetrated the Dakota sandstone the water failed to reach the surface by 80 feet. The water-bearing beds in the Dakota sandstone occur at several horizons, but the principal flows are found at some distance below the top bed of the formation. Different walls in the region vary somewhat as to the horizon of the principal flow. The strata lie nearly level or undulate very gently. A faint anticline appears to extend north and south through Miller, but it is very low.

Record of town well in Miller, Hand County.

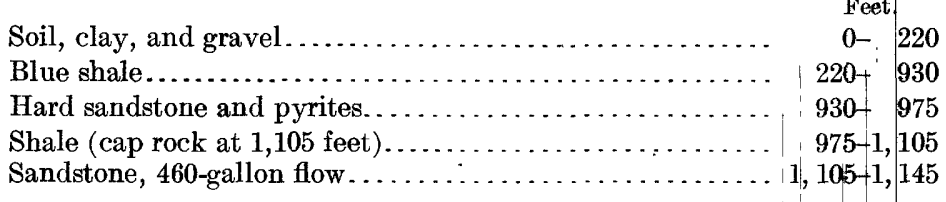

Artesian wells in Hand County.

L. L. Eiles, NW. $\frac{1}{4}$ sec. 21 , T. 110 , R. 68 Peter Myers, NE. $\frac{1}{4}$ sec. 28 , T. 110, R. 68 C. Rowen, NE, 1 sec. 8, T. $111, R, 66$. H. D. Ellis, SW. $\frac{1}{4}$ sec. 26, T. 112, R. 67 M. N. Strickling, SW. $\frac{1}{4}$ sec. 26 , T. 112, R. 67 St. Lawrence, sec. 7, T. 112, R. 67......... R. T. Sedam, sec. 18, T. 112 , R. 67 . John Baldwin, sec. 33, T. 112, R. 67 Township well, sec. 7, T. 112, R. 68 Miller, sec. 10, T. 112, R. 68..............

Miller, Lost Creek Ranch Co

Joseph Koeck, sec. 11, T. 112, R. 69.........

N. Noble, SW. $\frac{1}{4}$ sec. 20 , T. 113, R. 66....... A. B. Holmes, sec. 11, T. 113, R. 66......... Ick Brown, sec. 24, T. 113, R. 66

Will F. Pantsah, SW 1 sec. 15, T . 113, R. 66 D. Conkey, SE. 1 sec. $14, T \cdot 113, \mathrm{R} .67$. A. S. Piper, SE. $\frac{1}{4}$ sec. 15 , T. 113 , R. 67 . .

Township well, sec. 25 , T. 113, R. $67 . . . . . .$.

W. W. Cotton; SE. $\frac{1}{4}$ sec. 25 , T. 113, R. $67 .$.

Mr. Escher, SW. $\frac{1}{4}$ sec. 29, T. 113, R. 68

Gus Merion, SE. $\frac{1}{4}$ sec. 33 , T. 113, R. 69

Chas. Fuller, NE. $\frac{1}{4}$ sec. 13 , T. 113, R. 69

Mr. W yland, NW. 1 sec 14, T. 113 , R. 69

Township well, T. 113, R. 69

Sam Bushong, sec. 11, T. 114, R. 66 .

Frank Yodes, W. $\frac{1}{3}$ sec. 35, T. 114 R. 66 .

Thomas Jones, SE. $\frac{1}{4}$ sec. 27 , T. 114, R. 68

A. Gilmore, NE. $\frac{1}{4}$ sec. 12 , T. 114, R. 68 .....

Thomas E.Eaton, SW. $\frac{1}{4}$ sec. 9, T. 114, R. 68 J. C. Harris (?), SE. $\frac{1}{4}$ sec. 14, T. 114, R. 69 ..

Oliver McGee, sec. 15 , T. 114, R. 70 .

John J. Stornif.

H. Schoefers, SF. $\frac{1}{4}$ sec. $10, T$. 115, R. 69 .

Nabor Bros., NW. $\frac{1}{4}$ sec. 24, T. 115, R. 69.

J. B. Carl, SW. $\frac{1}{4}$ sec. 28 , T. 115, R. 70 ....

D. Countryman, sec. 26 , T. 116 , R. 67 .

\begin{tabular}{|c|c|c|c|c|}
\hline Depth & $\begin{array}{l}\text { Depth } \\
\text { to } \\
\text { water. }\end{array}$ & $\begin{array}{l}\text { Diam- } \\
\text { etepr. }\end{array}$ & $\begin{array}{l}\text { Average } \\
\text { yield } \\
\text { per } \\
\text { minute. }\end{array}$ & Remarks. \\
\hline $\begin{array}{r}\text { Feet. } \\
1,611 \\
838\end{array}$ & $\begin{array}{c}\text { Feet. } \\
\cdots \cdots \\
\cdots\end{array}$ & $\begin{array}{r}\text { Inches. } \\
2 \\
11\end{array}$ & \begin{tabular}{l} 
Gallons. \\
\hdashline$\quad 50$
\end{tabular} & \multirow[t]{2}{*}{ Water rises to -80 feet. } \\
\hline $\begin{array}{l}1,269 \\
1,246\end{array}$ & & $2-\frac{1}{4}$ & $\begin{array}{r}40 \\
40\end{array}$ & \\
\hline 1,272 & $\left\{\begin{array}{l}1,070 \\
1,272\end{array}\right.$ & $\cdots$ & Few. & Pressure 40 pounds. \\
\hline $\begin{array}{l}1,343 \\
1,375\end{array}$ & $\begin{array}{l}1,315 \\
1,343\end{array}$ & $\begin{array}{l}3 \\
3\end{array}$ & $\begin{array}{r}350 \\
1,350\end{array}$ & \multirow[t]{2}{*}{$\begin{array}{l}\text { Pressure } 125 \text { pounds. } \\
\text { Pressure } 119 \text { pounds. }\end{array}$} \\
\hline $\begin{array}{l}1,158 \\
1,200\end{array}$ & & $\begin{array}{l}1 \frac{1}{4} \\
4\end{array}$ & $\begin{array}{r}135 \\
50\end{array}$ & \\
\hline 1,140 & $\because, 1 i 0$ & & & \multirow{3}{*}{ Pressure 120 pounds. } \\
\hline 1,139 & 1,112 & $6 \frac{1}{4}-4 \frac{1}{2}$ & 360 & \\
\hline 1,142 & $\left\{\begin{array}{l}1,142 \\
1,030\end{array}\right.$ & $3-2$ & 40 & \\
\hline 1,207 & $\left\{\begin{array}{l}1,100 \\
1,207\end{array}\right.$ & 2 & 100 & Pressure 60 pounds. \\
\hline $\begin{array}{r}1,058 \\
980 \\
980 \\
967 \\
1,155\end{array}$ & 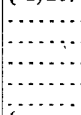 & $\begin{array}{l}1 \frac{1}{4} \\
2 \\
1 \frac{1}{4} \\
1 \frac{1}{4} \\
2 \frac{1}{2}\end{array}$ & $\begin{array}{r}35 \\
100 ? \\
35 \\
\ldots \ldots\end{array}$ & Water rises to +20 feet. \\
\hline 800 & $\left\{\begin{array}{l}1,087 \\
\text { ins }\end{array}\right.$ & 2 & & \multirow{10}{*}{ Pressure 128 pounds. } \\
\hline 1,137 & $\begin{array}{l}1,127 \\
1,100\end{array}$ & $\cdots$ & & \\
\hline 1,140 & $\begin{array}{l}1,112 \\
1,129\end{array}$ & 3 & 400 & \\
\hline $\begin{array}{l}1,125 \\
1,214\end{array}$ & 1,105 & $\begin{array}{l}3 \\
1 \frac{1}{4}\end{array}$ & 60 & \\
\hline 1,162 & & 2 & 100 & \\
\hline $\begin{array}{l}1,215 \\
1,200\end{array}$ & 1,190 & 2 & & \\
\hline 1,070 & & $1 \frac{1}{4}$ & 35 & \\
\hline $\begin{array}{l}1,010 \\
1,272\end{array}$ & & $1 \frac{1}{4}$ & 35 & \\
\hline 1,050 & & $1 \frac{1}{4}$ & 40 & \\
\hline $\begin{array}{l}1,185 \\
1,197\end{array}$ & 1,185 & $\begin{array}{l}11 \\
2\end{array}$ & 30 & \\
\hline 1,303 & & $\begin{array}{c}3-1 \frac{1}{4} \\
3\end{array}$ & $\begin{array}{r}15 \text { or } 25 \\
\ldots \ldots \ldots\end{array}$ & \multirow[t]{4}{*}{ In progress, 1903 . } \\
\hline 1,242 & & 2 & $\cdots 16$ & \\
\hline $\begin{array}{l}1,300 \\
853\end{array}$ & .... & 2 & 100 & \\
\hline 853 & & $1 \frac{1}{4}$ & & \\
\hline
\end{tabular}




\section{HANSON COUNTY.}

Hanson County is in the James River valley, its northern portion extending into the artesian basin. As the greater part of the county lies on the summit of the old buried ridge of Sioux quartzite, the Dakota sandstone is mostly absent. In the part of this area northeast of Mitchell, northwest of Spencer, east of Ethan, and on James

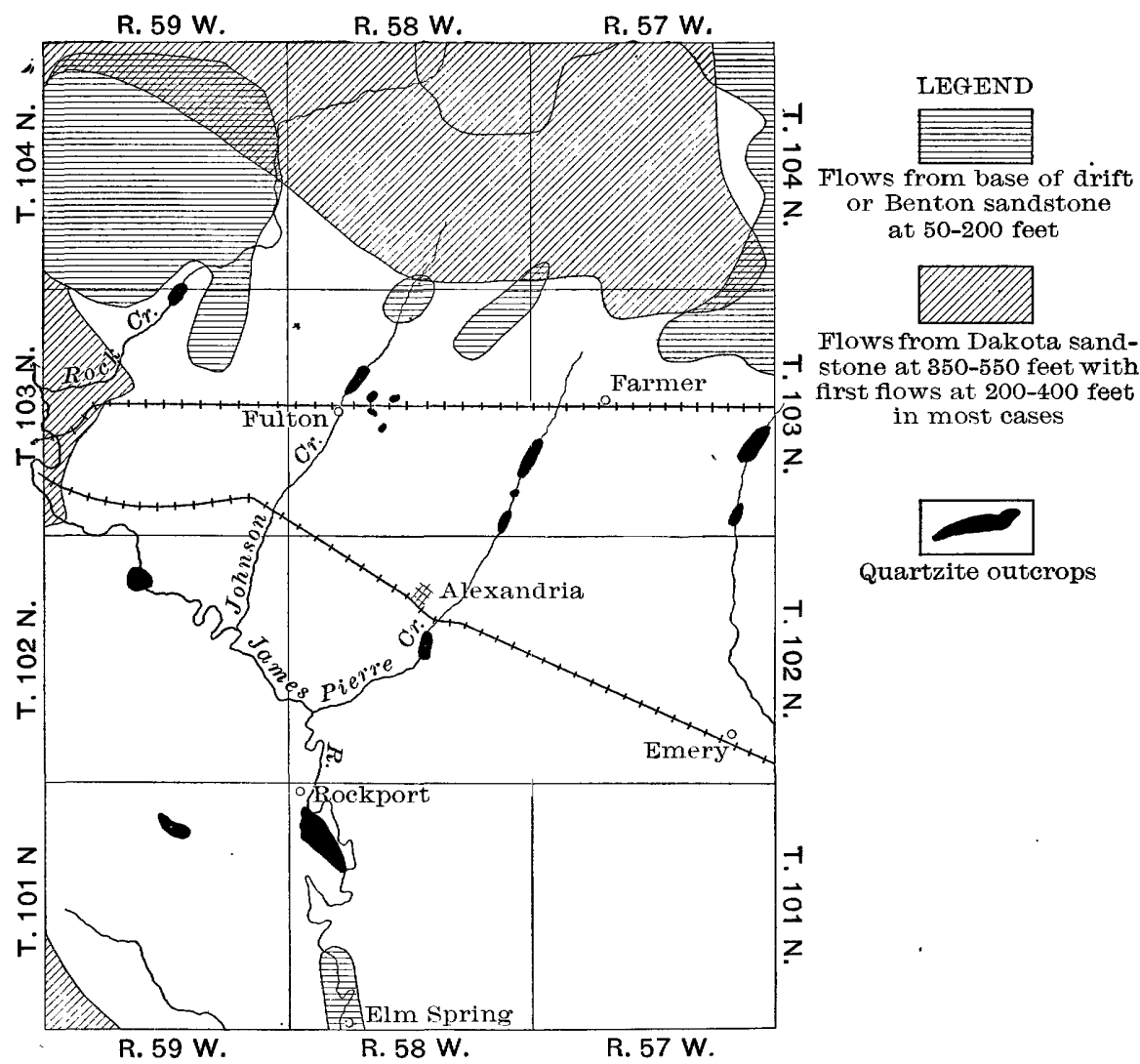

FIG. 6.-Map of Hanson County, showing artesiail eonditions. By the late C. M. Hall. No flows have been obtained in the white area.

River about Elm Springs, overlapping sandstones in the Benton group are sources of small artesian supplies. Small flows that are also obtained from the base of the drift are probably due to leakage from the Benton horizon. East of Mitchell the upper beds of Dakota sandstone appear to lie in a valley in the quartzite ridge for some distance and to contain water which affords flows on the lower lands along James River and on the slopes and upland just north of the mouth of Rock Creek. 
In the northwest corner of the county there is an area of about 30 square miles in which excellent flows are obtained from sandstone in the Benton group in wells 80 to 200 feet deep and from the base of the drift in shallower wells. These conditions continue to the east at intervals through the northern tier of townships, especially in the district north of Spencer. (See fig. 6.)

Artesian wells in Hanson County.

\begin{tabular}{|c|c|c|c|c|}
\hline $\begin{array}{l}\text { Town- } \\
\text { ship. }\end{array}$ & Range. & Depth. & $\begin{array}{l}\text { Average } \\
\text { yield } \\
\text { per } \\
\text { minute. }\end{array}$ & Kemarks. \\
\hline 101 & 58 & Feet. ${ }_{412}$ & Gallons. & 1 \\
\hline 103 & 56 & $\begin{array}{l}112,150 \\
165,260\end{array}$ & $\begin{array}{l}\text { Several. } \\
\text { Several. }\end{array}$ & $\begin{array}{l}\text { Flows from base of drift noth of Spencer only. } \\
\text { Flows from upper sandstone of Benton north of spencer } \\
\text { only. }\end{array}$ \\
\hline 103 & 57 & 127 & Several. & Flows from base of drift in sec. 11 only. \\
\hline 103 & 57 & $155-290$ & $5-40$ & $\begin{array}{l}\text { Flows from upper sandstone of Benton in northeastern } \\
\text { sections only. }\end{array}$ \\
\hline 103 & 57 & 400 & Many. & In sec. 4 from sandstone in Benton group. \\
\hline 103 & 58 & 140 & Several. & \\
\hline 103 & 59 & $135-176$ & Several. & Flows from base of drift. \\
\hline 103 & 59 & $400-470$ & Many. & Flows in northwestern sections only. \\
\hline 103 & 59 & 410 & None. & Insufficient head for flow in sec. 18 . \\
\hline 104 & 56 & $80-145$ & Several. & Flows from base of drift in western sections. \\
\hline 104 & 56 & $167-260$ & Several. & $\begin{array}{l}\text { Flows from upper sandstone of Benton in western sec- } \\
\text { tions. }\end{array}$ \\
\hline 104 & 57 & $152-170$ & Several. & Flows from base of drift. \\
\hline $\begin{array}{l}104 \\
104\end{array}$ & 57 & $170-365$ & $\frac{1}{2} 5$ & Flows from sandstones of Bienton. \\
\hline 104 & 58 & $\begin{array}{r}908-000 \\
90\end{array}$ & Several. & Flows from base of drift. \\
\hline 104 & 58 & $175-365$ & Several. & Flows from sandstones of Benton. \\
\hline 104 & 58 & $440-555$ & $30-150$ & No flows in secs. $30,31,32$, and 33 . \\
\hline
\end{tabular}

The main artesian basin extends under the greater part of T. 104 N., Rs. 57 and 58 E., in the northeastern and north-central parts of the county, where there are numerous wells 400 to 589 feet deep. They furnish large flows and usually have first flows also from sandstone in the Benton, which is the source of small flows in numerous wells 200 to 300 feet deep. A typical deep-well section in Hanson County is as follows:

Record of Knapp well, in sec. 13, T. 104, R. 58, Hanson County.

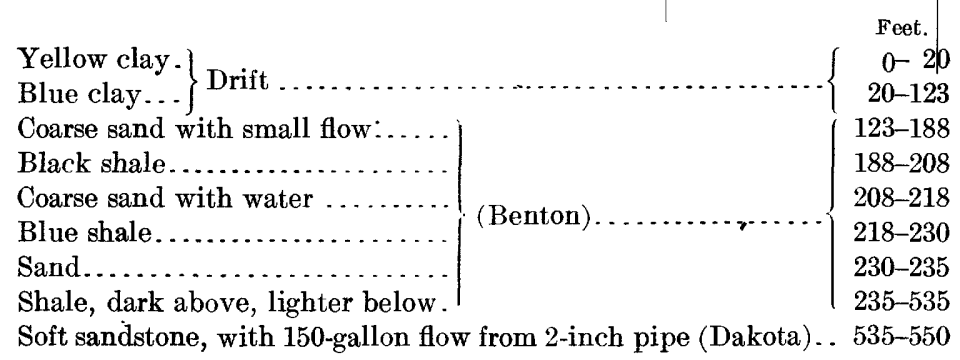


HUGHES COUNTY.

Hughes County extends from the Missouri Valley eastward on to the highlands. Most of the surface is covered with glacial deposits which are underlain by several hundred feet of Pierre shale. Under this is the usual succession of Niobrara formation, here mostly shale, Benton shales and sandstones, and Dakota sandstone lying on granite or quartzite. The sandstone is water bearing and the water appears to be under sufficient head to afford flows throughout the county. Its depth varies from 1,000 feet in the Missouri Valley at the south margin of the county to about 1,600 feet in the highest lands in the northwest portion. The beds dip gently to the northwest.

There are several wells at Pierre and vicinity, one at Harrold, and another just to the north in Sully County. The three wells at Pierre are $1,160,1,256$, and 1,537 feet deep, the two latter having, it is asserted, passed through the sandstone to granite. The greatest pressure reported is 210 pounds to the square inch, sufficient to raise the water to an altitude of 1,920 feet above sea level. The Pierre wells yield large flows of water, with considerable gas, which has been found useful. The following record is reported by Mr. Swan, the driller: ${ }^{a}$

Record of well at Pierre, Hughes County.

\begin{tabular}{|c|c|}
\hline Sand and gravel.. & $\begin{array}{l}\text { Feet. } \\
0-\quad 62\end{array}$ \\
\hline ray snale... & $62-\quad 87$ \\
\hline Black shale.. & $87-275$ \\
\hline Blue shale. .................. & $275-\quad 325$ \\
\hline Light-gray shale................ & $325-$ \\
\hline Dark-gray shale............................. & $425-$ \\
\hline Lime rock, hard....... & $476-$ \\
\hline Blu & 479 \\
\hline Lime rock (hard) ............ & $530-$ \\
\hline 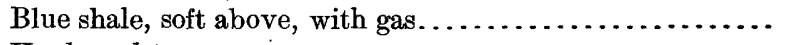 & $533-$ \\
\hline$\ldots \ldots \ldots \ldots \ldots \ldots \ldots \ldots \ldots \ldots \ldots \ldots \ldots \ldots \ldots \ldots \ldots \ldots$ & $650-654$ \\
\hline$t$ flows at 870 and 890 feet......... & $654-1,085$ \\
\hline 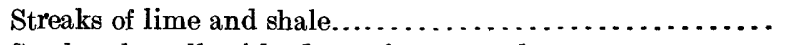 & 130 \\
\hline of wotor and $\mathrm{mos}$ &, 140 \\
\hline Stre & $1,140-1,175$ \\
\hline of gas and water...... & $1,175-1,185$ \\
\hline Streaks of shale, lim & $1,185-1,215$ \\
\hline $\begin{array}{l}\text { White sand, soft; main flow, } 210 \text { pounds pressure, tempera- } \\
\text { ture } 89^{\circ} \ldots \ldots \ldots \ldots \ldots \ldots \ldots \ldots \ldots \ldots\end{array}$ & \\
\hline treaks of white shale and lime & \\
\hline & \\
\hline
\end{tabular}

Todd reports that there is no question as to the identity of the granite claimed to have been penetrated for 6 feet at the bottom of the well. Another well sunk recently a short distance farther west found 
the granite at a depth of 1,537 feet, a discrepancy difficult to account for.

The well at Harrold is at the altitude of 1,081 feet, and the water is under sufficient pressure to rise 62 feet higher, yielding a flow of 84 gallons per minute from a 4-inch pipe. The well is 1,453 feet deep and has the following record:

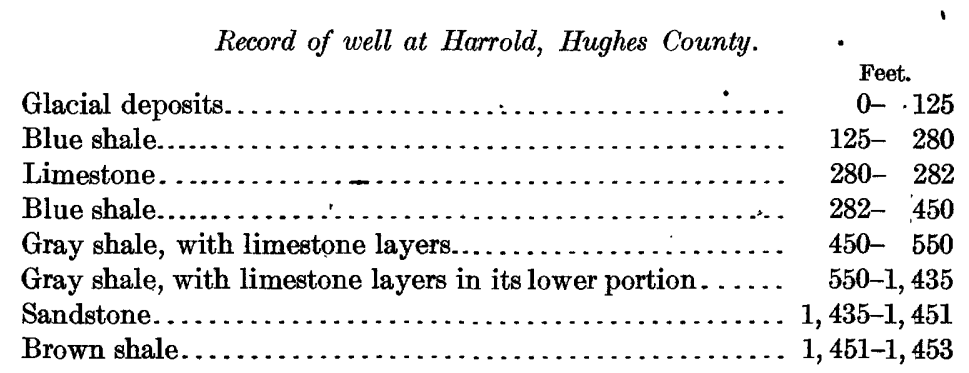

\section{HUTCHINSON COUNTY.}

Hutchinson County is partly in the James River valley and extends up the slopes of the adjoining highlands to the east and to the west. The surface is mostly covered by glacial drift, but in some of the valleys there are outcrops of Niobrara chalkstone and the sandstone at the top of the Benton group. The Dakota sandstone underlies the greater part of the county, but to the north abuts against the Sioux quartzite and ends, the overlying formations extending beyond, up the slopes of an underground ridge. The formations all dip gently toward the southwest along the slope of this ridge.

The depth to the Dakota sandstone is slightly less than 300 feet along James River, gradually increasing in the higher lands to the west and to the east. In the southwest corner of the county the sandstone lies nearly 800 feet beneath the surface, and in the southeast corner 700 feet. It contains large volumes of water under considerable pressure, which is sufficient to afford flows in the lower lands but not in the higher areas in the eastern and extreme southwestern portions of the county. There are several horizons of flow in the region, beginning with sandstones in the Benton and comprising two or three thick sandstone layers in the Dakota. These are tapped by numerous wells in the northwestern, central, and southern portions of the county. Some of the wells obtain their waters from the top of the sandstone, and others penetrate to lower horizons to obtain increased volume and pressure.

In the eastern portion of the county several wells have been sunk to quartzite which found no water or found only supplies in the Benton sandstones that lacked sufficient head to flow. Flows are obtained from the Benton sandstones at Elm Springs and at some 
other points in the area in which the Dakota sandstone is absent, and from this source several wells in the region to the west have obtained supplies of moderate volume. The principal features of the representative wells in this county are set forth in the following table:

Artesian wells in Hutchinson County.

\begin{tabular}{|c|c|c|c|c|}
\hline $\begin{array}{l}\text { Town- } \\
\text { ship. }\end{array}$ & Range. & Depth. & $\begin{array}{l}\text { Average } \\
\text { yield per } \\
\text { minute. }\end{array}$ & Remarks. \\
\hline 97 & 56 & $\begin{array}{l}\text { Feet. } \\
445-480\end{array}$ & Gallons. & No flow \\
\hline & & & $27-60$ & Flows from base of drift. \\
\hline 97 & 57 & $\begin{array}{r}65-154 \\
417 \\
406-630\end{array}$ & $\begin{array}{r}\text { 3-10 } \\
\text { Few. } \\
\text { Many. }\end{array}$ & $\begin{array}{l}\text { Flows only in valleys, from base of drift. } \\
\text { Low pressure; Menno town well. } \\
\text { Pressure } 25 \text { pounds. }\end{array}$ \\
\hline 97 & 59 & $\begin{array}{r}747 \\
480-620 \\
300 \\
500\end{array}$ & $\begin{array}{r}6 \\
30-50 \\
\text { Few. }\end{array}$ & $\begin{array}{l}\text { Pressure } 25 \text { to } 35 \text { pounds; several flows. } \\
\text { Flows from sandstone in the Benton. } \\
\text { Sec. } 26 \text {. }\end{array}$ \\
\hline 97 & 60 & $540-614$ & $40-50$ & \\
\hline & & $\begin{array}{r}648-760 \\
824\end{array}$ & $\begin{array}{r}50-100 \\
700\end{array}$ & $\begin{array}{l}\text { Pressure } 35 \text { to } 60 \text { pounds. } \\
\text { Pressure } 9 \text { pounds; Tripp town well. }\end{array}$ \\
\hline 97 & 61 & $\begin{array}{r}30-62 \\
945\end{array}$ & 6 & Flows from base of drift. \\
\hline 98 & 56 & $53-54$ & $4-9$ & Do. \\
\hline $\begin{array}{l}98 \\
98\end{array}$ & $\begin{array}{l}57 \\
58\end{array}$ & $\begin{array}{r}55-65 \\
420\end{array}$ & $1-3$ & Do. \\
\hline 98 & 59 & $40-200$ & Several. & $\begin{array}{l}\text { Flows from base of drift and upper sandstone in the } \\
\text { Benton. }\end{array}$ \\
\hline 98 & 60 & $\begin{array}{l}370-450 \\
470-580 \\
120-180\end{array}$ & $\begin{array}{r}1-15 \\
16-120\end{array}$ & 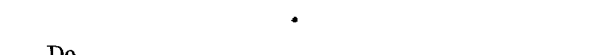 \\
\hline 98 & 61 & $\begin{array}{l}120-189 \\
482-560\end{array}$ & $\begin{array}{r}\text { Several. } \\
13-60\end{array}$ & Do. \\
\hline 99 & 56 & $\begin{array}{r}64-130 \\
54-95\end{array}$ & $\begin{array}{r}6-10 \\
10-12\end{array}$ & $\begin{array}{l}\text { Flows from base of drift. } \\
\text { Do. }\end{array}$ \\
\hline 99 & $\begin{array}{l}57 \\
58\end{array}$ & $\begin{array}{r}150 \\
270-335\end{array}$ & $1-10$ & Wolf Creek. \\
\hline & & 280 & & No flows in northern section. \\
\hline 99 & 59 & $365-490$ & Many. & Flows from base of drift \\
\hline 99 & 60 & $\begin{array}{l}470-540 \\
100-130\end{array}$ & $5-150$ & Do. \\
\hline & & $\begin{array}{r}360-440 \\
542\end{array}$ & 30 & $\begin{array}{l}\text { First flows from lower sandstones of the Benton. } \\
\text { Pressure } 20 \text { pounds; Parkston town well. }\end{array}$ \\
\hline 99 & 61 & $\begin{array}{r}515-535 \\
140\end{array}$ & $10-50$ & $\begin{array}{l}\text { Pressure } 13+\text { pounds. } \\
\text { Flows from base of drift. }\end{array}$ \\
\hline 100 & 59 & $\begin{array}{l}490-572 \\
180-220 \\
240-345\end{array}$ & $\begin{array}{l}8-50 \\
\cdots \cdots\end{array}$ & First flows from lower sandstones of the Benton. \\
\hline 100 & 60 & 560 & 10 & \\
\hline 100 & 61 & $\begin{array}{l}370-462 \\
296-340 \\
419-585\end{array}$ & $\begin{array}{r}3-10 \\
\text { Many. } \\
1-90\end{array}$ & $\begin{array}{l}\text { First flows from lower sandstones of the Benton. } \\
\text { Flows from upper sandstone of the Benton. }\end{array}$ \\
\hline
\end{tabular}

The wells at Tripp and Parkston have the following records: Record of well at Tripp, Hutchinson County.

Drift.

Chalkstone (probably a portion of these 300 feet comprises light-

colored clays in the lower part of the drift deposits).......... 25-325

Sandstone (top of the Benton) . . . . . . . . . . . . . . . . . . . 325-425

Shale......................................... 425-525

Sandstone.................................... $525-529$

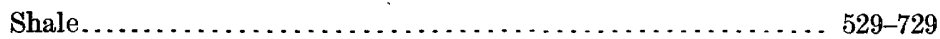

Sandstone and shale........................... $729-764$

Sandstone with flowing water...................... 764-824 
Record of well at Parkston, Hutchinson County.

Yellow clay

Feet.

Sand with water

0 - 40

Blue shale.

Gray shale with water.

225-434

Gray shale.

434-444

Fine sandstone.

$444-460$

Shales, with hard layers above and sand layers below, with flow $472-542$

Very hard rock.

542

\section{HYDE COUNTY.}

Hyde County extends north and south along the summit of the high divide between the Missouri and James River valleys, the higher portions of which attain an altitude of over 2,000 feet above sea level. The surface is thickly covered with glacial drift, with underlying Pierre, Niobrara, and Benton shales more than 1,400 feet thick, lying on Dakota sandstone. Three borings have been reported-one at Highmore, with a depth of 1,552 feet; another at the Mitchell the ranch, 8 miles northeast, with a depth of 1,397 feet; and a third at Begun ranch, in the NE. $\frac{1}{4}$ sec. 30 , T. 114 N., R. 71 E., 1,380 feet deep, with a 30-gallon flow and 30 pounds pressure. All obtain flows from the Dakota sandstone. The pressure in the Highmore well is stated to be 12 to 15 pounds to the square inch, indicating a head of 1,920 feet above sea level, a pressure insufficient to afford flows on the high summits south of Highmore and on the high ridges northwest.

The well at Highmore is at an altitude of 1,890 feet; the depth is 1,552 feet, diameter 6 inches, and flow about 9 gallons per minute. The principal flow was obtained from a depth of 1,537 feet. Nonflowing water was found in a bed of sandstone, probably in the Benton group, extending from 1,430 to 1,442 feet. The following is the $\log$ of this well:

Record of town well at Highmore, Hyde County.

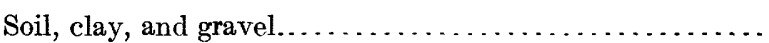

Feet.

$0-240$

Blue shale.

$240-740$

Hard gray shale, pyrites ........................ $740-815$

Blue shale................................. 815-1,086

Gray shale mixed with sand .................... 1,086-1,310

Shale and pyrites............................. 1, 310-1, 314

Blue shale.................................. 1,314-1,430

Sandstone; no flow........................... 1,430-1,442

Sandy shale, on bed of hard sand.................. 1,442-1,537

Soft sandstone............................. 1,537-1,552 


\section{JERAULD COUNTY.}

Jerauld County extends from the western part of the James River valley onto the high drift ridges to the west. The surface is covered with drift lying on Pierre shale. Under this shale there is the usual succession of Niobrara chalkstone, Benton shales and sandstones, and Dakota sandstone lying on granite and quartzite, the beds dipping gently to the north.

The Dakota sandstone contains water under pressure sufficient to afford flows except on the highlands in the central portion of the county. There are numerous wells with large flows in the eastern third of the county, which average for the most part from 715 to 850 feet in depth and furnish large volumes of water under pressure of 90 to 132 pounds, indicating that flows may be expected in all portions of the area having an altitude of less than 1,700 feet. The following is a list of the wells that have been reported:

Artesian wells in Jerauld County.

\begin{tabular}{|c|c|c|c|c|}
\hline $\begin{array}{l}\text { Town- } \\
\text { ship. }\end{array}$ & Range. & Depth. & $\begin{array}{l}\text { Average } \\
\text { yield per } \\
\text { minute. }\end{array}$ & Remarks. \\
\hline $\begin{array}{l}106 \\
106 \\
107 \\
107 \\
108 \\
108\end{array}$ & $\begin{array}{l}63 \\
64 \\
64 \\
65 \\
63 \\
64 \\
\\
65\end{array}$ & $\begin{array}{r}\text { Feet. } \\
715-760 \\
735-880 \\
860 \\
1,200 \\
785 \\
799 \frac{1}{2} \\
840-865 \\
1,057\end{array}$ & $\begin{array}{r}\text { Gallons. } \\
200-280 \\
5-280 \\
35 \\
1 \\
500 \\
2 \\
45 \\
200\end{array}$ & $\begin{array}{l}\text { Water irony. } \\
\text { Pressure } 90 \text { pounds. }\end{array}$ \\
\hline
\end{tabular}

Records of some typical wells in Jerauld County are as follows:

Record of well of S. H. Albert, sec. 5, T. 108 N., R. 65 E., Jerauld County.

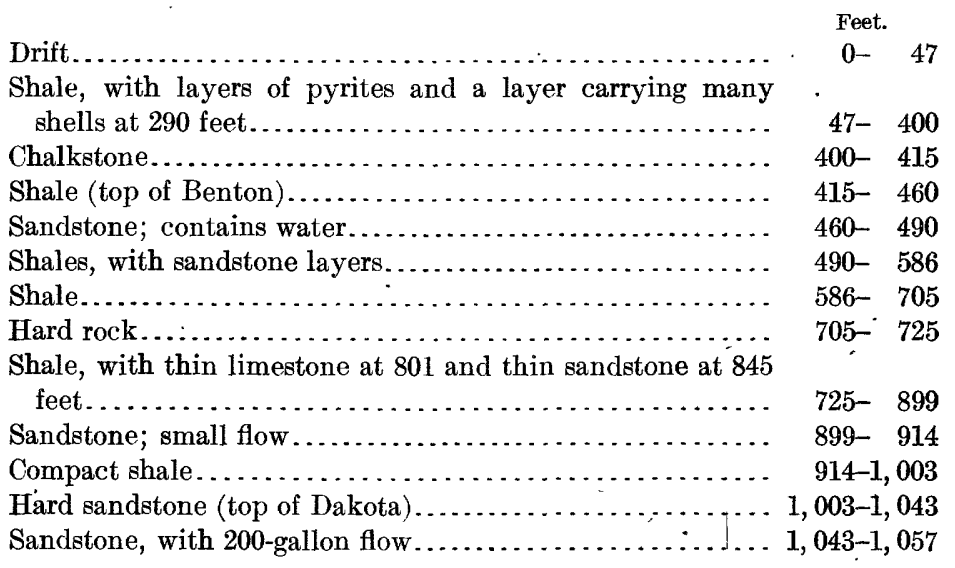

In the well of P. Schultz, in sec. 9, T. 106 N., R. 64 E., the first water was found under chalk at 290 feet below the surface, and the Dakota 
sandstone was reached at 836 feet and yielded a 280-gallon flow at 880 feet.

Record of well of E. Schmidt, sec. 14, T. 108 N., R. 64 E., Jerauld County.

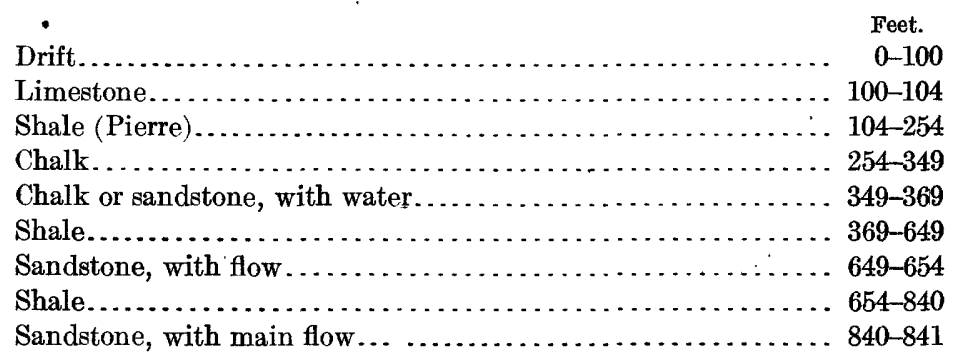

Record of well of K. Feistner, NW. $\frac{1}{4}$ sec. 2, T. 106 N., R. 63 E., Jerauld County.

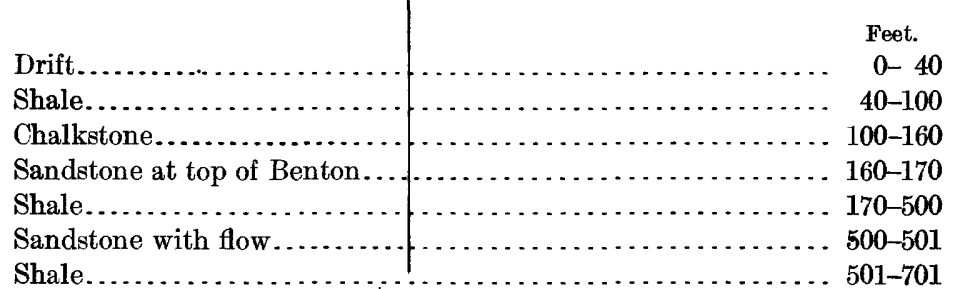

Top sandstone of Dakota, with main flow................. 701-721

\section{KINGSBURY COUNTY.}

The artesian conditions in Kingsbury County present considerable variety, the lower lands in the western portion of the county lying sufficiently low to be within reach of flowing water, while to the east, in the higher coteau country, the land is too elevated for flows from the Dakota sandstone horizon. The entire county is underlain by Pierre shale overlain by Pleistocene depesits, which have considerable thickness in the coteau region to the east. Many wells, most of which yield large flows, have been bored in the western part of the county. The first one sunk was at Iroquois, where, at a depth of 1,115 feet, a flow of 1,000 gallons per minute was obtained. The well penetrated the Pierre, Niobrara, and Benton. Small flows were found in thin sandstone layers at 400 and 600 feet, and the main flow was struck in the Dakota sandstone, which was entered at 847 feet. The pressure was reported to be 67 pounds per square inch in 1890 , but a determination in 1899 gave 71 pounds. Other wells have since been sunk, mostly in the western portion of the county, having depths of 815 to 1,120 feet and yielding from 20 to 100 gallons a minute, with surface pressures of 8 to 50 pounds to the square inch. Several wells in various places obtain water supplies from a sandstone horizon just below the first great body of shales, probably at the top of the Benton group, but these have to be pumped. 


\section{GEOLOGY AND UNDERGROUND WATERS OF SOUTH DAKOTA.}

The surface of the Dakota sandstone slopes gently northwestward, with slight local undulations. East of a line passing north and south near Manchester the land rises abruptly to the northeast from an average altitude of 1,500 feet to over 1,800 feet on the summit of the coteau. As the head of the water in the Dakota sandstone is from 1,550 to 1,615 feet on the west and 1,680 at De Smet, it is evident that no flows are obtainable in the wide coteau area.

The following is a list of the deep borings so far reported in the county:

\section{Deep borings in Kingsbury County.}

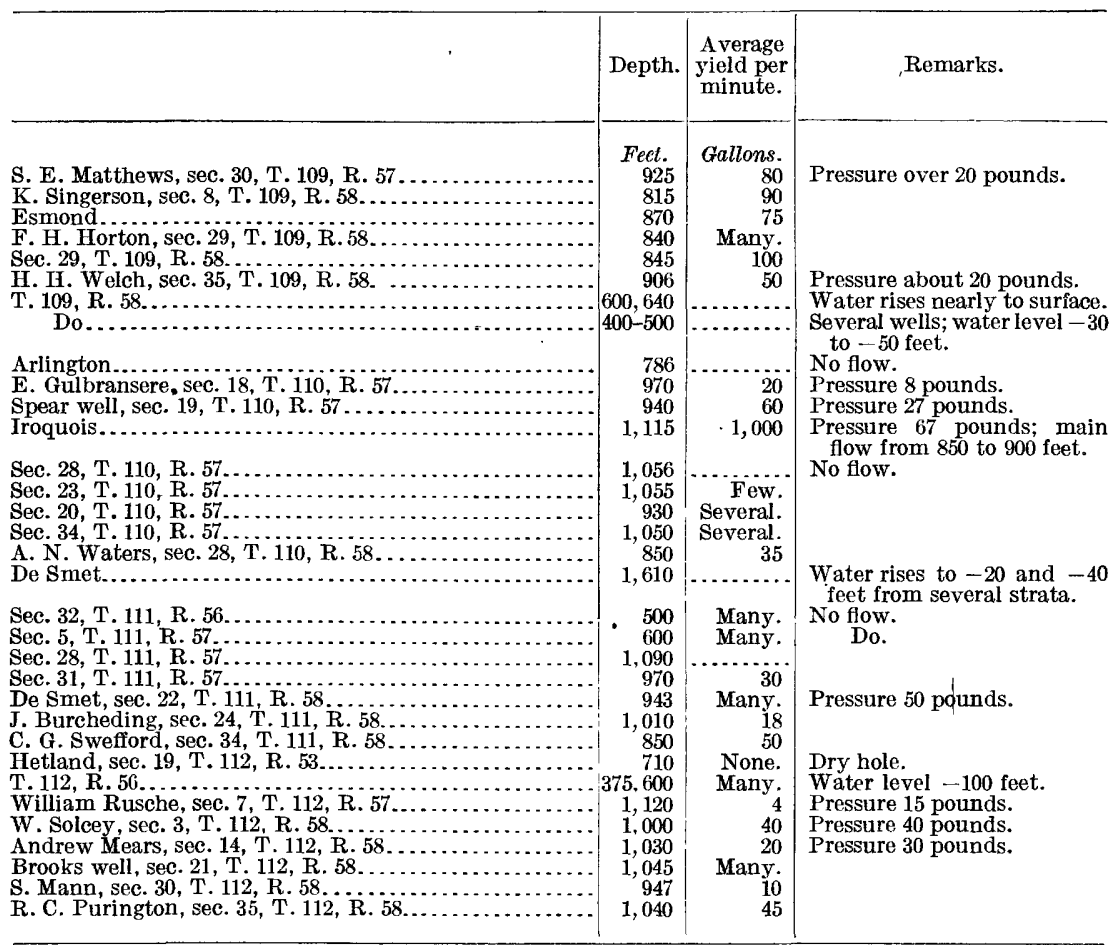

The following records show the principal geologic features in some representative wells in Kingsbury County:

Record of artesian well at Iroquois.

Clay .................................... ${ }_{0}{ }^{\text {Feet. }} 45$

Shale..................................... $45-400$

Sand, with water.......................... 400- 402

Shale........................................ 402- 600

Sand, with water. . . . . . . . . . . . . . . . . . . $600-602$

Shale....................................... 602- 850

Sandstone, with 1,000-gallon flow.................. 850- 900

Shale................................... 900-1, 100 
The shale from 45 to 400 feet is probably comprised in the Pierre and Niobrara formations, the latter here consisting of materials not sufficiently calcareous to be reported as chalkstone, a deposit which characterizes the formation farther south. In this well the formations of the Benton group extend from 400 to 847 feet, where the top of the Dakota sandstone was entered.

Another well 4 miles northeast of Iroquois, on land 100 feet higher than the Iroquois well, obtains a large flow from a depth of 916 feet with a pressure of 50 pounds.

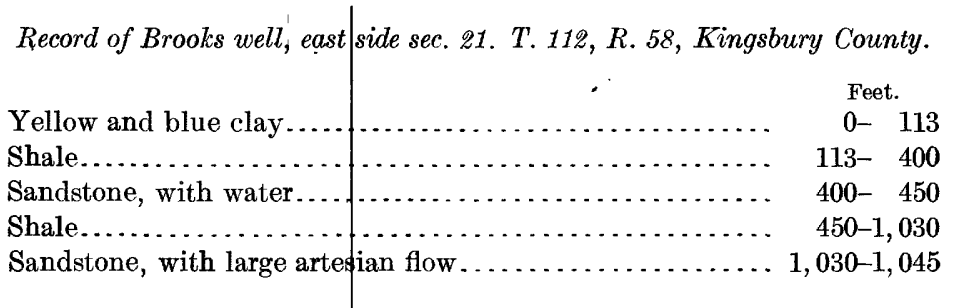

This record is very similar to that of the Iroquois well, 9 miles to the southwest. The sandstone extending from 400 to 450 feet probably represents the sandstone bed which usually characterizes the top or upper portion of the Bønton group in eastern South Dakota and furnishes water for many deep-pumped wells in portions of Kingsbury County and elsewhere.

Record of Spear artesian well, NE. $\frac{1}{4}$ sec. 19, T. 110, R. 57, Kingsbury County.

\begin{tabular}{|c|c|}
\hline & Feet. \\
\hline Yellow clay .......... & \\
\hline Blue clay and sand.. & $36-140$ \\
\hline Black shale.......... & $140-390$ \\
\hline Gray shale.................... & $390-485$ \\
\hline Sandstone; water rising to-111 feet......... & $485-505$ \\
\hline 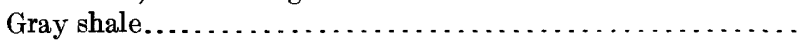 & $505-862$ \\
\hline 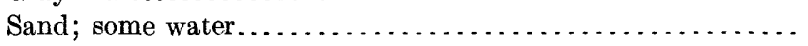 & $862-863 \pm$ \\
\hline Shale.................... & $863-932$ \\
\hline Sandstone; 60 -gallon flow... & $932-937$ \\
\hline Hard rock......................... & $937-940$ \\
\hline
\end{tabular}

The black shale from 140 to 390 feet is undoubtedly Pierre, and apparently the gray shale below represents the Niobrara. The waterbearing sandstone extending from 485 to 505 feet is the usual feature at or near the top of the Benton group, and the sandstone entered at 932 feet is the Dakota, with a large volume of water showing a surface pressure of 27 pounds. 
Record of deep boring at De Smet.

\begin{tabular}{|c|c|}
\hline o & Feet. \\
\hline Clay... & $0-44$ \\
\hline & $44-104$ \\
\hline & $104-$ \\
\hline Hard rock... & $840-$ \\
\hline 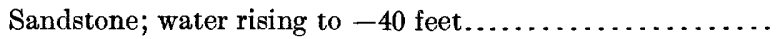 & $865-985$ \\
\hline ale, or "soapstone," with fish teeth at 1,145 feet.......... & $985-1,185$ \\
\hline 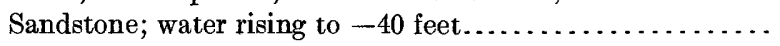 & $1,185-1,456$ \\
\hline 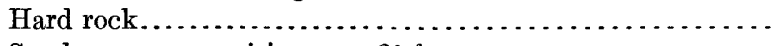 & $1,456-1,470$ \\
\hline ndstone; water rising to -20 feet... & $1,470,1,610$ \\
\hline
\end{tabular}

This boring was sunk with the hope of finding an artesian flow, but was unsuccessful owing to the height of the land. It is claimed that a large volume of water was found, but it failed to reach the surface by 20 to 40 feet. The first 104 feet of the boring are in drift, and from 104 to 1,185 feet it goes through the Pierre, Niobrara, and Benton. In one log the first water-bearing sands were reported from 763 to 793 feet, and in another from 865 to 985 feet; probably both were in the top of the Benton group. The hard rock from 840 to 865 feet may be a limestone such as occurs in the lower part of the Niobrara formation in some regions. A stratum, said to be 1 foot thick, largely composed of fish teeth, was reported at a depth of 1,148 feet, apparently in the lower formation of the Benton group. The Dakota sandstone appears to have been penetrated from 1,185 to 1,610 feet, a thickness of 425 feet, without reaching its base. This boring shows that probably no flows are obtainable on the coteau.

A well at Arlington is reported to have reached a depth of 786 feet without obtaining a flow. It is almost certain that it did not reach the Dakota sandstone, which probably lies at a depth of 1,100 feet. As the altitude of the town is 1,846 feet and the head of the water in the Dakota sandstone is probably less than 1,700 feet, a flow could not be expected.

The following record of the Arlington boring has been reported:

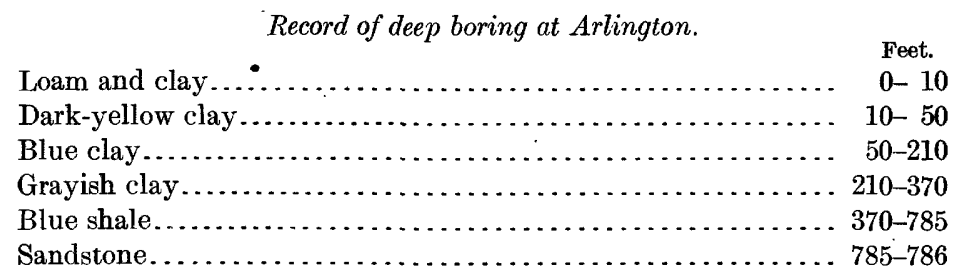

Another similar deep boring was sunk at Hetland, in sec. 19, T. 112 N., R. 53 E., but was entirely dry. 
Record of deep boring at Hetland.

Black loam.........................................

Yellow clay

Blue clay

Soft yellow clay.

Shell rock

Yellow clay

Blue shale.

Record of deep boring in $S W . \frac{1}{4} \mid$ sec. 35, T. 109 N., R. 58 E, Kingsbury County.

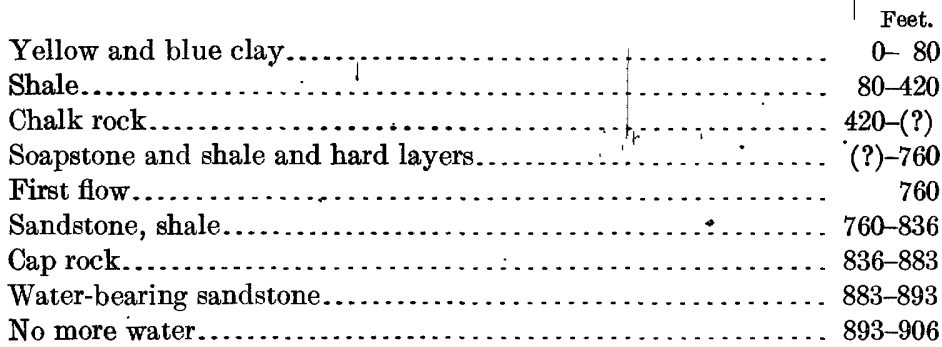

Record of deep boring in_SE. $\frac{1}{4}$ sec. 30, T. 109 N., R. 5\% E., Kingsbury County.

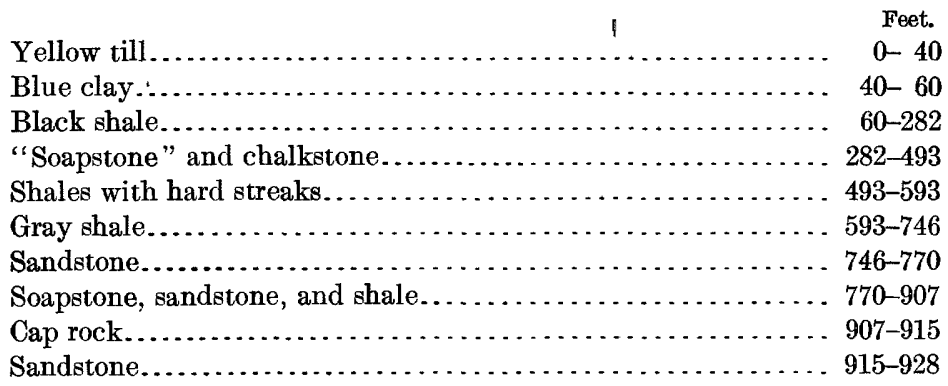

A well recently bored in the eastern part of sec. $28, T$. 110 N., R. $57 \mathrm{E}$., is reported to have reached a depth of 1,056 feet and obtained water in the Dakota sandstone, which rose within 20 feet of the surface. Quartzite was found at the bottom of the boring. Another well in the SW. $\frac{1}{4}$ sec. 23 of the same township of about the same depth obtained water which rises to the surface, but with so low a pressure that the flow is very slight. Hard rock also stopped boring operations in this well. A 1,050-foot well in sec. 34 and a 930 -foot well in sec. 20 have good flows but they are on lower ground.

\section{LAKE COUNTY.}

A buried valley in the quartzite and granite, which extends north and south through the center of Lake County, apparently contains the Dakota sandstone, but the altitudes of the land are too great for the formation to afford a flow. 
At Madison a boring was sunk to a depth of 1,082 feet, which appears to have been mainly in shale and to have obtained no water supply. Lime rock, which was reported from 490 to 570 feet, resting on sandstone, suggests the Niobrara chalk, but aside from this there is no evidence as to the geology of the boring. As the bedrock surface is known to rise rapidly to the west, south, and east, it is evident that there is a deep trough at Madison, probably opening to the north, as shown in Plate $\mathrm{X}$. Whether this trough contains the Dakota sandstone or not remains to be demonstrated, but if it does it is not to be expected that its water will have sufficient head to reach the surface, which at Madison is 1,669 feet above sea level.

\section{LAWRENCE COUNTY.}

Lawrence County is on the northeastern slope of the Black Hills uplift, extending far into the region of crystalline rocks to the south and out on the plains of Benton shales to the northeast. In the northern half of the county the rocks dip mainly to the north and northeast and pass underground in regular succession from the old crystalline schists to the Benton shales. In the extreme northeast corner of the county the Dakota sandstone lies about 1,000 feet below the surface in a shallow syncline which pitches to the north. Probably its greatest depth in the county is 900 feet, in the ridges northeast of St. Onge.

Doubtless the sandstone would yield flowing water in the lower lands, as indicated by the experience of wells at Belle Fourche, a short distance farther north. It is probable that in the Red Valley in this county underground waters could be obtained by sinking into the Minnelusa sandstone, and possibly also in the underlying Deadwood sandstone. The depth from the middle of the Spearfish red beds to the top of the Minnelusa sandstone is about 500 feet, the top of the Deadwood sandstone lying about 1,000 feet deeper.

A recent boring at the electric-light plant in the canyon $1 \frac{1}{2}$ miles south of Spearfish has a depth of 415 feet. Water which flowed 20 gallons a minute was found at 323 feet in yellow sandstone of the Minnelusa. The flow increased to 50 gallons as this formation was bored through to its bottom at 398 feet. The Pahasapa limestone was penetrated for 17 feet but yielded no water.

A well $2 \frac{1}{2}$ miles northwest of Spearfish, in the NW. $\frac{1}{4}$ sec. 4, T. 6 N., R. 2 E., 312 feet deep, obtains a flow of 15 gallons from a depth of 305 feet. The city of Spearfish is sinking a well to obtain a flow from the Minnelusa sandstone.

\section{LINCOLN COUNTY.}

Apparently only the extreme southwest corner of Lincoln County is underlain by the Dakota sandstone, and it is believed that the 
water of that formation does not have sufficient head to reach the surface in flowing wells. The Sioux quartzite rises to the surface in the northeastern portion of the county and slopes gently to the southwest, where it is overlain by a greater or less thickness of Benton shales and Niobrara chalk.

\section{LYMAN COUNTY. ${ }^{a}$}

Lyman County extends from Missouri River 85 miles westward over the plains lying between Bad and White rivers. It is underlain almost entirely by the Pierre shale, except along the Missouri River and in its vicinity, where the underlying Niobrara chalkstone is exposed. A few of the higher points are capped by remnants of Tertiary deposits, notably at White Clay and Medicine buttes. Under the Pierre clay there is the usual succession of Niobrara chalkstone, Benton shales, and Dakota sandstone, the Dakota lying on the granite or quartzite to the east, but possibly overlapping rocks of Paleozoic and early Mesozoic age in the western portion of the county.

The Dakota sandstone contains water in large volume and under sufficient pressure to afford a flow in all the valleys and probably for some distance up the slopes. Owing to lack of knowledge of the topography of the county and the precise head of the waters in its western part, the nonflowing areas can not be accurately delimited. The water has been developed by several wells in the Missouri Valley opposite Chamberlain, by the McClure well on Cedar Creek, 18 miles south-southeast of Pierre, and by wells at Capa, Vivian, and Kennebec, on the new lines of railroad.

The Dakota sandstone in this county appears to dip gently westward and its depth also increases to the west by the gradual rise of the land in that direction. The wells on Missouri River reach it at a depth of about 550 feet, the amount increasing somewhat both up and down the river and rapidly in the highlands to the west. In the divide between Medicine Creek and White River it lies at least 1,400 feet below the surface to the east and at White Clay Butte somewhat more than 2,000 feet. On White River, at the western border of the county, probably the depth is nearly 1,700 feet, and on Bad River it is nearly 1,600 feet, as shown by the well at Capa.

Wells opposite Chamberlain.-The wells opposite Chamberlain are of moderate depth. One on the farm of G. S. Grant, in sec. 14, T. 104 N., R. 72 E., is 563 feet deep and 2 inches in diameter. The first flow was reported at 360 feet, the second flow at 460 feet, and the main flow at the top of the Dakota sandstone at 560 feet. Another well, on the farm of $\mathrm{E}$. A. Barlow, on a bench a mile back from the river in the southern part of T. 104 N., R. 71 E., has a depth of 600 
feet and a diameter of 2 inches. Its flow is small. The AdamsBrinkehoff well in the NW. $\frac{1}{4}$ sec. 7, T. 104 N., R. 71 E., has a 2 -inch bore, is 737 feet deep, and flows several hundred gallons per minute. The pressure of the water in these wells is not given; but to judge from that in the wells at Chamberlain, it is probably sufficient to raise the water to 1,800 feet above sea level.

McClure well.-The McClure well is in sec. 31 or 32 , T. 108 N., R. $78 \mathrm{E}$., and has a depth of 1,653 feet. The inner tube is $1 \frac{1}{4}$ inches in diameter and is reported to yield a flow of 40 gallons per minute with a pressure of 20 pounds. A special line of levels was run to this well, and it was found to be at an altitude of 1,917 feet, so that the pressure of 20 pounds indicates that the water at this place had sufficient head to rise to 1,963 feet above sea level, which, with the probable slight increase to the west, is sufficient to afford flows in portions of the county not on the higher divides. The record of the McClure well is reported as follows:

Record of McClure well, sec. 31 or 32, T. 108, R. 78, Lyman County.

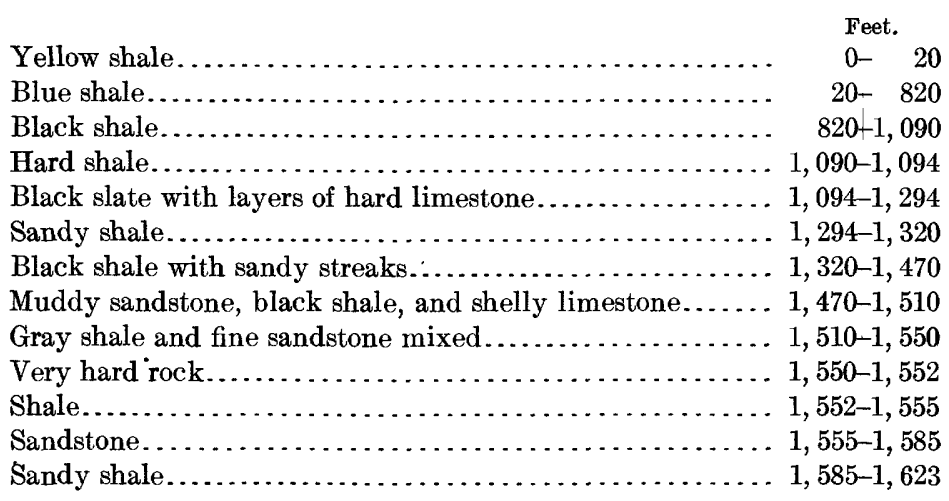

There is some uncertainty in this record as to whether the Dakota sandstone was reached at 1,470 feet or 1,555 feet.

Capa.-A boring at Capa, a siding on the extension of the Chicago and Northwestern Railway from Pierre to Rapid, is 3 inches in diameter and has a depth of $1,689 \frac{1}{2}$ feet and a flow of about 100 gallons a minute. It has a 2 -inch screen at the bottom. The temperature of the water is $118^{\circ}$. The materials penetrated were shale, which below 1,000 feet contained thin strata of limestone. The Dakota sandstone, was entered at 1,500 feet. Water began to flow 18 gallons a minute between 1,560 and 1,580 feet, and the main flow is at 1,650 feet. Gas was encountered at a depth of 1,560 feet and rises in considerable amount. The cost of this well was $\$ 2,676$. 
An analysis of the water from this well at a depth of 1,650 feet, made by G. M. Davidson, chemist of the Chicago and Northwestern Railway Company, showed that it contains the following ingredients:

Analysis of water from well at Capa.

[Hypothetical compounds.]

Carbonate of lime.

$$
\text { [Hypothetical compounds.] }
$$

Carbonate of magnesia

Oxides of iron and aluminum

Silica.

Alkaline chlorides

Alkaline sulphates.

Alkaline carbonates.

Organic matter.

Total solids

It is considered a poor water for boiler use on account of foaming.

Kennebec. - A well sunk in 1907 at Kennebec, on the new railroad extension west from Chamberlain, is 1,301 feet deep and obtains a 50-gallon flow from the Dakota sandstone. The principal flow began at a depth of 1,246 feet, presumably at the top of the formation. The diameter of the well is $\beta$ inches at the top, with intake through a $1 \frac{1}{4}-$ inch screen. The pressure appears to be moderate, but it was not gaged. The temperature of the flow is about $96^{\circ}$. The altitude of Kennebec is 1,688 feet.

Vivian.-Vivian is a new station on the railroad 25 miles west of Kennebec, at an altitude of 1,895 feet. A well completed in 1906 to a depth of 1,610 feet yields a 20 -gallon flow, and the principal waterbearing sandstone was entered at a depth of 1,530 feet. The size of the boring is the same as in the well at Kennebec.

Draper.-Draper is on the high divide at the head of Medicine Creek, its altitude being $2,230 \frac{1}{2}$ feet. It is on the western extension of the Chicago, Milwaukee and St. Paul Railroad. A well bored by the railroad in 1907 has a depth of 2,005 feet and a diameter of $2 \frac{1}{2}$ inches, and yields 10 gallons a minute. The Dakota sandstone was penetrated for 130 feet. Owing to the height of the land the water does not flow, but it rises within 200 feet of the surface. It is lowered 200 to 300 feet by pumping.

- Murdo McKenzie.-A boring at Murdo McKenzie, the next station west of Draper, reached a depth of 2,135 feet. It entered sandstone, which only yielded a small water supply. The elevation of the land, 2,318 feet, is too great for a flow. 


\section{M'COOK COUNTY.}

The area of artesian flows in McCook County appears to be restricted to the west half of the northwesternmost townships, where, in an area of about 35 square miles, there are several small flowing wells. These derive their waters either from the basal drift gravels or from the chalk below, in an extension of the shallow artesian region of Sanborn County. To the east and south the quartzite rises nearly to the surface and cuts off the source of supply.

The following list comprises all the flowing wells in McCook County from which returns were received:

Artesian wells in McCook County.

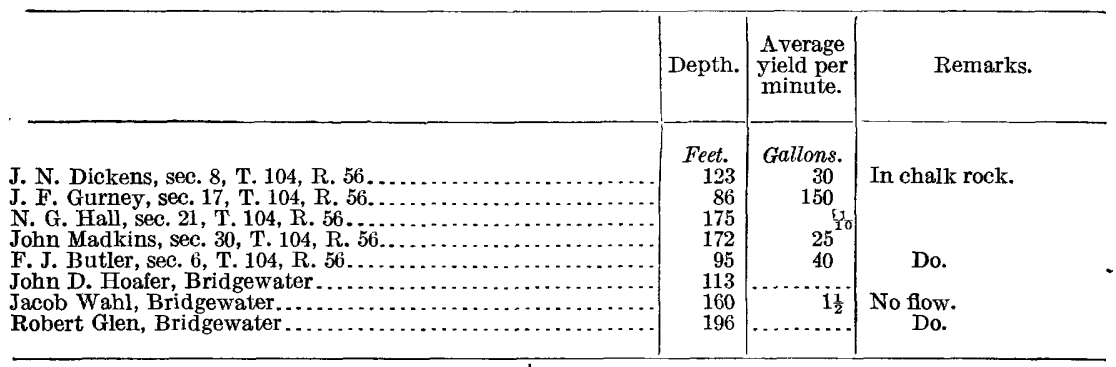

These wells, which are all of 2-inch bore, usually supply hard water. The yield of those that flow is reported to be decreasing.

The quartzite lies only 100 to 154 feet below the surface about Spencer, and at various depths from 150 to 500 feet or more in the region to the south and east. At Salem, according to Nettleton, it was found at a depth of 222 feet and was penetrated for 25 feet. Water which rose to within 75 feet of the surface was found in this boring in sand at a depth of 215 to 220 feet. At Bridgewater a similar water horizon was found at a depth of 224 feet, but the bottom of rhe boring, at 229 feet, did not reach the quartzite.

\section{M'PHERSON COUNTY.}

McPherson County lies largely upon the western coteau but also includes in its eastern part an extensive area in the valley of James River. In the highlands there is a thick deposit of glacial drift and the plain is mostly covered by Quaternary deposits of various kinds. The Cretaceous clays vary in thickness from about 1,100 feet in the southeast corner of the county to 1,600 feet or more in the highlands of the west, and these figures also represent the depth to the Dakota sandstone. This formation, containing a large volume of artesian water, underlies the entire county, but the head is only sufficient to afford flows up to altitudes of about 1,800 feet or possibly slightly less, to judge by the pressure in the wells on the higher slopes. During the last few years numerous wells have been sunk in the eastern por- 
tion of the county and flows of large volume have been obtained. Most of the wells are on the plain at altitudes from 1,400 to 1,600 feet, but a number of them have recently been sunk on the lower slopes rising to the coteau.. The following list includes all which have been reported:

Artesian wells in McPherson County.

\begin{tabular}{|c|c|c|c|c|c|c|c|}
\hline $\begin{array}{l}\text { Town- } \\
\text { ship. }\end{array}$ & Range. & Depti. & $\begin{array}{l}\text { Yield per } \\
\text { minute. }\end{array}$ & $\begin{array}{l}\text { Town- } \\
\text { ship. }\end{array}$ & Range. & Depth. & $\begin{array}{l}\text { Yield per } \\
\text { minute. }\end{array}$ \\
\hline $\begin{array}{r}125 \\
125 \\
125 \\
a 125 \\
126 \\
126\end{array}$ & $\begin{array}{l}66 \\
67 \\
68 \\
69 \\
66 \\
67\end{array}$ & $\begin{array}{r}\text { Feet. } \\
1,160 \\
1,165-1,190 \\
1,260-1,280 \\
1,507 \\
1,150-1,180 \\
1,230-1,290\end{array}$ & $\begin{array}{r}\text { Gallons. } \\
40 \\
20-160 \\
30-100 \\
8 \\
40-60 \\
30-35\end{array}$ & $\begin{array}{r}126 \\
127 \\
127 \\
b 127 \\
128 \\
128\end{array}$ & $\begin{array}{l}68 \\
66 \\
67 \\
68 \\
66 . \\
67\end{array}$ & $\begin{array}{c}\text { Feet. } \\
1,102-1,280 \\
1,150 \\
1,220-1,330 \\
1,485 \\
1,170-1,280 \\
1,300-1,725\end{array}$ & $\begin{array}{r}\text { Gallons. } \\
50 \\
80 \\
30-80 \\
11 \\
\text { - } 25-40 \\
25-30\end{array}$ \\
\hline
\end{tabular}

- In SE. $\frac{1}{4}$ sec. 24 .

$b$ In NE. $\frac{1}{4}$ sec. 24 .

MARSHALL COUNTY.

Marshall County includes the northern part of the high coteau and also extends westward across part of the plain of the James River valley. The coteau is a high ridge of glacial deposits which, together with the plain to the west, is underlain by a thick mass of Cretaceous clays. The Dakota sandstone underlies the entire county; having a depth of slightly less than 1,000 feet in the plain but being very much deeper under the highlands of the coteau. It has a very gentle dip to the west and lies on granite or other crystalline rocks which have been reached in a well at Veblen at a depth of 860 feet and in one at Britton at a depth of 1,030 feet. The sandstone is undoubtedly water bearing throughout, but as the maximum altitude of the head of the water is only about 1,700 feet, calculated from the pressure at Britton, and as the land on the summit of the coteau has an elevation of somewhat more than 1,750 feet, flowing wells are not obtainable in the east-central and southeastern portions of the county. The following is a list of wells in Marshall County so far as reported:

Artesian wells in Marshall County.

\begin{tabular}{|c|c|c|c|}
\hline & Depth. & $\begin{array}{l}\text { Yield per } \\
\text { minute. }\end{array}$ & Remarks. \\
\hline 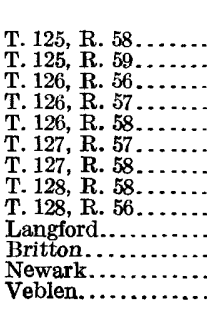 & $\begin{array}{r}\text { Feet. } \\
960- \\
990 \\
925-930 \\
980 \\
890-1,125 \\
940-965 \\
938-1,152 \\
929 \\
930 \\
980 \\
1,050 \\
1,004 \\
940 \\
860\end{array}$ & $\begin{array}{r}\text { Gallons. } \\
35-50 \\
10-25 \\
60 \\
10-35 \\
10-95 \\
6-40 \\
35 \\
30 \\
18 \\
400 \\
600 \\
600 \\
\frac{1}{3}\end{array}$ & $\begin{array}{l}\text { Pressure } 60 \text { pounds; } 6 \text {-inch well. } \\
\text { Pressure } 150 \text { pounds; } 31 \text {-inch well. } \\
\text { Pressure } 125 \text { pounds; } 6 \text {-inch well. } \\
\text { Pressure } 15 \text { pounds; salty water. }\end{array}$ \\
\hline
\end{tabular}


MEADE COUNTY.

Meade County extends northeastward from the flanks of the Black Hills to the divide between Owl River and Sulphur Creek. To the east it extends for some distance along the west side of Cheyenne River, and it comprises the lower portion of the Belle Fourche Valley. A wide range of formations is included within its limits, extending from the granites and schists in the Black Hills uplift to the lignitebearing sandstones and shales in the highlands north of the Belle Fourche. On the slopes of the Black Hills the older rocks are exposed, dipping so steeply to the northeast that within a short distanee they are carried to a considerable depth. The dip diminishes away from the hills and thence, to the northeast, the strata lie nearly horizontal.

The Dakota and associated sandstones are exposed in the hogback range, and to the east pass beneath the surface, so that along Belle Fourche River they lie at depths of 1,900 to 2,000 feet in the lowlands and of more than 2,500 feet on the divides. Probably they lie still deeper in the northeastern portion of the county. These sandstones contain artesian water, which enters at an altitude of 3,500 feet or more, so that it has sufficient head to afford artesian flows in the lower lands toward the east. A number of wells have been sunk to these sandstones in the region north of Sturgis and obtain large flows of excellent water. The following is a list of wells in the county:

Artesian wells in Meade County.

\begin{tabular}{|c|c|c|c|c|c|c|}
\hline . & Depth. & $\begin{array}{l}\text { Depth } \\
\text { to } \\
\text { main } \\
\text { flow. }\end{array}$ & $\begin{array}{l}\text { Diam- } \\
\text { eter. }\end{array}$ & $\begin{array}{l}\text { Yield } \\
\text { per } \\
\text { minute. }\end{array}$ & Pressure. & Remarks. \\
\hline N. P. Hansen, NW. $\frac{1}{4}$ sec. 15 , T. 6 , & $\begin{array}{l}\text { Feet. } \\
1,116\end{array}$ & $\begin{array}{l}\text { Feet. } \\
1,090\end{array}$ & Inches. & $\begin{array}{r}\text { Gallons. } \\
35\end{array}$ & Pounds. & Flows 5 feet above \\
\hline $\begin{array}{l}\text { R. }-5 . \\
\text { R. Stephens, NE. } \frac{1}{4} \text { sec. } 22 \text {, T. 6, R. } 5 \\
\text { K. F. Kambisch, sec. } 20 \text {, T. } 6 \text {, R. } 5 \text {. }\end{array}$ & $\begin{array}{l}377 \\
720\end{array}$ & $\begin{array}{l}357 \\
480\end{array}$ & $\stackrel{2}{2}$ & $\begin{array}{r}60 \\
\text { Many. }\end{array}$ & -...... & $\begin{array}{l}\text { surface; soft. } \\
\text { Soft water. } \\
\text { No increase of water } \\
\text { below } 500 \text { feet; water } \\
\text { rises to }-4 \text { feet, soft. }\end{array}$ \\
\hline J. S. Jensen, SE. $\frac{1}{4}$ sec. 8, T. 6, R. $5 .$. & 632 & 600 & 2 & Many. & 20 & $\begin{array}{l}\text { Water at } 300 \text { feet also; } \\
\text { soft. }\end{array}$ \\
\hline $\begin{array}{l}\text { J. H. Enskert, sec. } 26, \text { T. } 6, \text { R. } 5 \ldots \\
\text { Bear Butte Oil Co., SE. } \frac{1}{4} \text { sec. } 8 \text {, } \\
\quad \text { T. } 6, \text { R. } 5 \text {. }\end{array}$ & $\begin{array}{r}1,310 \\
755\end{array}$ & 600 & & Small. & 20 & In progress. \\
\hline $\begin{array}{l}\text { W. H. Bowman, sec. } 2, \text { T. } 6, \text { R. } 5 . . \\
\text { J. Dacy, } 5 \frac{1}{2} \mathrm{~m} \text {. E. of Whitewood, } \\
3 \mathrm{~m} \text {, N. and } 2 \mathrm{~m} \text {. W. of B. B. O. } \\
\text { Co.'s. }\end{array}$ & $\begin{array}{r}1,560 \\
570\end{array}$ & $570^{\circ}$ & & $\begin{array}{r}4 \\
\text { Many. }\end{array}$ & Few. & First flow at 330 feet. \\
\hline Fort Meade (U. S, ) .................. & 1,450 & 322 & .... & 12 & & $\begin{array}{l}\text { No water below a good } \\
\text { flow at } 322 \text { feet. }\end{array}$ \\
\hline
\end{tabular}

Wells north of Sturgis.- The first well in this district, in the SE. $\frac{1}{4}$ sec. 8 , T. 6 N., R. 5 E., about 6 miles north of Sturgis, was completed in February, 1904. It was sunk for oil, but found a large flow of water at a depth of 600 feet, in an 85-foot bed of white Lakota sandstone. The well has a diameter of $3 \frac{3}{4}$ inches and a total depth of 755 feet, and 
the pressure is said to be sufficient to raise the water 35 feet or more above the surface. The following record is furnished:

Record of artesian well 6 miles north by west of Sturgis.

Dark shale.

Feet.

Light shale and sand.

$0-275$

Red clay.

$275-435$

"Rocks"

$435-505$

Soft sandstone with large flow of water at about 600 feet. ..... 585-670

Coal, 1 inch thick................................. $\quad 670$

Dry sand ........................................ 670-685

Black shale with 2 -inch coal...................... 685-705

Green shale with thin limestone layers.................. 705-755

A small flow was found at 440 feet. The altitude of the surface at this boring was 3,225 feet. It began in the Graneros shale, passed through 70 feet of the Fuson formation from 435 to 505 feet and through 180 feet of the Lakota sandstone, and penetrated 70 feet into the Morrison.

The well of Mr. Jensen is reported to have passed through 40 feet of surface material, 250 feet of shale, 10 feet of sandstone, 240 feet of hard shale, and 92 feet of sandstone which yields the water supply.

In the Stephens well the first 250 feet are blue shales, which are underlain by 25 feet of sandstone, followed by 82 feet of gray shales and 22 feet of sandstone containing water.

It is probable that in the Red Valley, in the western part of this county, the Minnelusa sandstone would be reached at moderate depths and would furnish water supplies, and it is possible also that waters under considerable pressure might be obtained from the underlying Deadwood sandstone, about 1,000 feet deeper.

Fort Meade.-Several years ago a well which was sunk by the quartermaster's department at Fort Meade, just east of the Dakota hogback range, developed a 12-gallon flow of excellent water at a depth of 322 feet. With the expectation of finding additional supplies it was continued deeper and went through the Spearfish red shales to the Minnekahta limestone, where, unfortunately, it was discontinued without testing the prospects of obtaining water in the upper part of the Minnelusa sandstone, 100 feet or more below. The record of this boring, based mainly on samples furnished by the quartermaster, is as follows:

Record of boring at Fort Meade, Meade County.

\begin{tabular}{|c|c|}
\hline Sandstone and gravel.. & \\
\hline 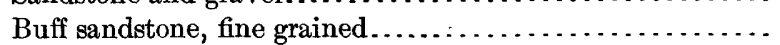 & $25-$ \\
\hline 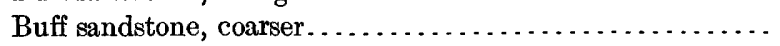 & $50-$ \\
\hline 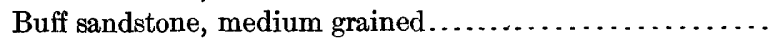 & $75-$ \\
\hline Gray shale.................... & 100 \\
\hline Yellow sandstone, fine grained..................... & $125-$ \\
\hline
\end{tabular}




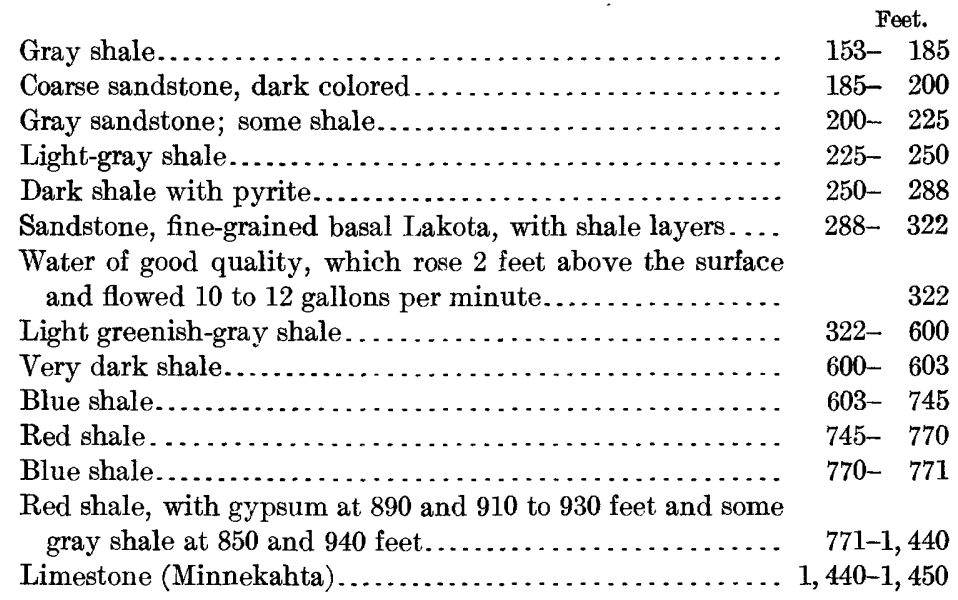

\section{MINER COUNTY.}

Miner County lies on the east side of the James River valley and extends eastward up the slope of the coteau, its western half lying in the Dakota artesian basin. The surface of the county is covered by glacial deposits, which lie on the Pierre shale in the central and northern parts and on the Niobrara chalkstone in the southern part. There is the usual succession underground of Niobrara and Benton underlain by Dakota sandstone, except in the east-central and southeast portions of the county, where this sandstone abuts against an underground ridge of Sioux quartzite, on which the overlying formations overlap toward the east. In the western half of the county the formations dip gently to the northwest, away from the quartzite ridge.

The depth to the Dakota sandstone is 375 feet in the southwest corner of the county; it increases gradually to the east and then to the north, being from 750 to 800 feet along the north margin. Throughout its extent the sandstone contains water under sufficient head to afford vigorous flows in the lower lands comprising the western half of the county. An 884-foot well at Carthage obtains a flow from a depth of 768 feet, and numerous deep wells in the southwestern townships obtain flows from the Dakota sandstone at depths of 380 to 550 feet. In these two southwestern townships flows are also obtained at depths of 150 to 250 feet from sandstones in the Benton, and also at depths of 50 to 140 feet from the base of the drift deposits. These shallow wells are numerous in the southwest corner of the county and afford excellent water supplies for local use. Ordinarily the deeper wells are sunk only where the shallower horizons do not afford sufficient supplies. In the central-western portion of the county there are 
numerous wells about 400 feet deep which obtain water from the sandstone underlying the Niobrara chalkstone, but the water has to be pumped to the surface. The following is a list of wells in this county:

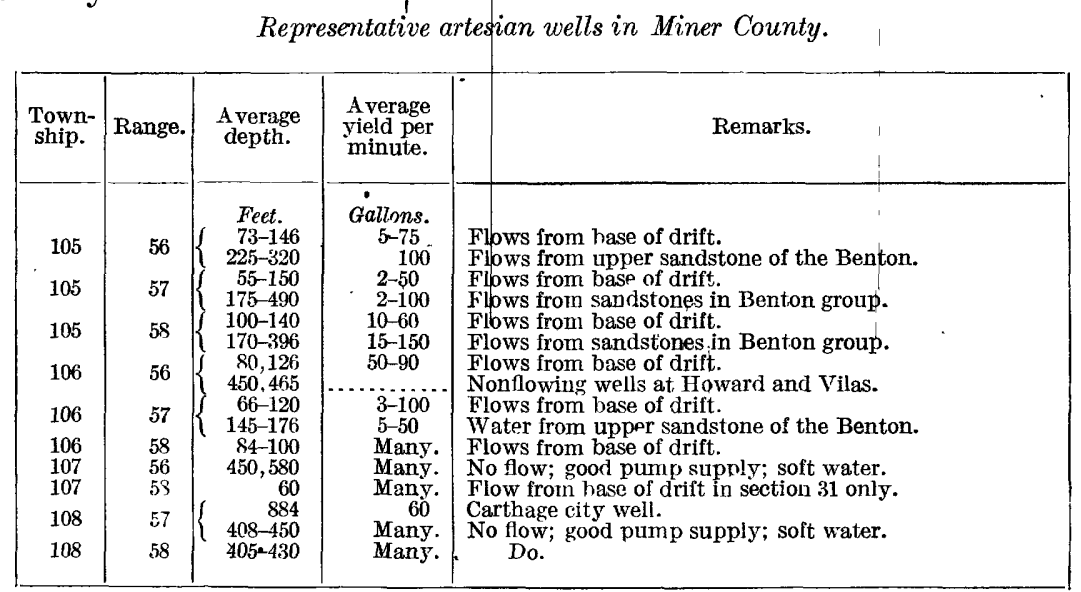

\section{MINNEHAHA COUNTY.}

The Dakota sandstone appears not to extend into Minnehaha County, unless possibly under a small area in its northwest corner. The Sioux quartzite has been reached by numerous borings at no great depth, and in many places is overlain by a greater or less thickness of Benton shàles and Niobrara chalk. The quartzite outcrops extensively along Sioux River and some of its branches. In some places wells in this quartzite obtain a small amount of water from crevices, but a boring 575 feet deep at Sioux Falls failed to obtain any useful amount of water and was in quartzite throughout. It was found that the formation varied somewhat in hardness.

\section{MOODY COUNTY.}

The Dakota sandstone appears to be entirely absent in Moody County. The Pierre, Niobrara, and Benton formations lie on the Sioux quartzite, which outcrops in the southern portion of the county and has been reached by numerous.wells to the north. Some of the sandy beds in the Benton yield small amounts of water, but without sufficient head to flow at the surface. Seven miles southeast of Flandreau the pipestone of the Sioux quartzite was penetrated for 230 to 236 feet under sand, shale, and sandy shale. About 5 miles west-southwest of the same town a well 455 feet deep found water in sand, and at Flandreau water is obtained in sand at a depth of 126 'feet. The Sioux quartzite is reported at a depth of 100 feet north of Flandreau and at about the same depth 10 miles northeast of that place. 
A well about 2 miles east of Trent is reported to have the following record:

Record of well in sec. 8, T. 105, R. 48, near Trent.

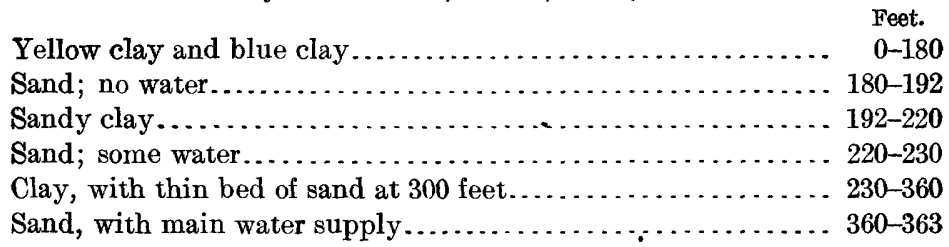

PENNINGTON COUNTY.

The geologic relations in Pennington County are very similar to those in Custer County, except that the dips on the east side of the Black Hills uplift average somewhat less. They are sufficient, however, to carry the Dakota and associated sandstones rapidly beneath the surface, so that at a distance of 10 miles east of the hogback range their top is at a depth of 2,000 feet. In the valley of Rapid Creek, in the eastern portion of the county, the sandstone is believed to lie at a depth of about 2,400 feet, and along Cheyenne River at depths of 2,100 to 2,300 feet, as nearly as can be éstimated from a determination of the structure of the Pierre shale based on the distribution of the tepee butte zone. Several borings of moderate depth have been made east of Rapid, but they have not been sufficiently deep to reach the Dakota sandstone. It is stated that in one boring half a mile southeast of Rapid a sandstone, probably a sandy layer in the Benton, was penetrated at a depth of 400 feet and yielded a small flow. It is probable that the Dakota sandstone would yield flows throughout the portion of this county east of the hogback range, except on the higher divides. The prospects for underground waters in the Red Valley are the same as in Custer County.

A boring recently completed at Wasta on Cheyenne River is 2,287 feet deep. At 2,208 feet a three-foot bed of sandstone was penetrated which yields water rising to within 300 feet of the surface, here 2,315 feet above sea level. The supply is 40 gallons a minute with a 4 -inch pump barrel at a depth of 900 feet. The sandstone evidently is the Benton, and it is greatly to be regretted that the boring was not sunk a few hundred feet deeper to test the Dakota and underlying sandstones, which doubtless would yield a strong flow.

\section{PINE RIDGE INDIAN RESERVATION.}

The large Pine Ridge Indian Reservation extends from the valleys of Cheyenne and White rivers onto the high table-land of Pine Ridge, comprising broad valleys, extensive badlands districts, and wide areas of high plains. The altitudes range from 2,100 feet or more in the White River valley, in the extreme northwest corner of the reservation, to 3,800 feet or more in the high ridges east of the 
agency. The high plains are heavily mantled by soft sandstone of the Arikaree formation, and the lower slopes are occupied mostly by the underlying White River group, which has been exposed by erosion, giving rise to extensive badlands. In the northeastern and western portions of the reservation the Pierre shale is cut into by White and Cheyenne rivers, and in the extreme southwest corner Niobrara and Benton appear. The geologic structure is probably relatively simple, the strata in the eastern portion of the area dipping gently to the west and those in the western portion dipping gently to the east on the slope of the Black Hills uplift.

Along White River, in the southwest corner of the reservation, there is a sharp local uplift by which the Niobrara and the Benton are exposed. The depth to the Dakota sandstone varies considerably in the reservation, owing largely to variations in the altitude of the land. As the thickness of the overlying Benton, Niobrara, and Pierre has not been very accurately ascertained, the depth to the Dakota sandstone, as indicated on the map ( $\mathrm{Pl}$. XI), is only approximate, and for the south-central part of the reservation, where the Arikaree formation hides the underlying strata, no estimates can be made. The thickness of the Pierre shale doubtless reaches a thousand feet in the northwest corner of the reservation, but the amount diminishes gradually to the east. The Benton group, which has a thickness of somewhat more than 1,300 feet on the southeast slopes of the Black Hills, undoubtedly thins rapidly to the east, for it has less than half of that amount on Missouri River. The Niobrara chalk and associated deposits probably preserve a thickness of about 200 feet throughout. The White River beds lie on a somewhat uneven surface of Pierre shale, eroded so that its thickness varies considerably. From these factors it is believed that the Dakota sandstone lies at a depth of about 1,800 feet along White River in the extreme northeast portion of the reservation, and that the amount gradually increases toward the west, to 2,300 feet near Interior, a thickness which is probably uniform nearly to the mouth of White Clay Creek. Thence to the south the uplift brings the Dakota sandstone very much nearer the surface, so that near the state line on White River it is probably not more than 1,100 or 1,200 feet deep in the center of the anticline. At the Pine Ridge Agency the sandstone will probably be found at a depth of 1,400 to 1,500 feet. In the divide between White and Cheyenne rivers and in the badlands slope south of White River, east of the mouth of Wounded Knee Creek, the Dakota sandstone lies 2,500 feet or more below the surface.

To judge from the general slope of the head of the water in the Dakota sandstone between the Black Hills and the Missouri Valley and toward the east, it is probable that flowing water may be expected in the Pine Ridge Reservation in the valleys of Cheyenne and White 
rivers, up to an altitude of 3,000 feet in the northwest corner, 2,600 feet in the north-central portion, and 2,200 feet in the eastern portion. This area comprises all the bottom lands, a moderate proportion of the slopes, and the lower portions of the valleys of the side streams of Cheyenne River and White River valleys below Interior post-office. According to the best estimates the Pine Ridge Agency is at an altitude of 3,300 feet, so that there is no probability of obtaining a flow in the White Clay Valley at that place.

\section{POTTER COUNTY.}

Potter County extends eastward from Missouri River, comprising a narrow area of lowlands in the valley with a rapid rise toward the east to an elevated undulating district of drift hills. Along the river the altitude is about 1,500 feet; in the highlands it is mostly about 1,800 feet, though in portions of them it is considerably above 2,000 feet. The region is underlain by a thick mass of Pierre shale mantled by glacial deposits and underlain by Benton and Niobrara shales and the Dakota sandstone. The sandstone contains a large volume of water under great pressure, as demonstrated by the well at the Cheyenne Agency, on the opposite side of Missouri River, and the well at Gettysburg. The agency well, having a pressure of 205 pounds to the square inch, indicates a head sufficient to raise the water to an altitude of 1,970 feet. The Gettysburg well, which is on land having an altitude of 2,082 feet, has a water level 108 feet below the surface, indicating a head of 1,974 feet. In the adjoining county to the east the head is less, indicating a rise to the west. Two wells on the highlands just east of Missouri River obtain satisfactory flows--one east of Forest City at 1,604 feet and the other south of Forest City at 1,761 feet.

From these facts it is evident that artesian waters would be available in Potter County in all but the very highest lands, which comprise the elevation on which Gettysburg is situated and the Bowdle Hills along the eastern margin of the county.

The Gettysburg well has a depth of 2,130 feet. It is 3 inches in diameter and yields soft water, the principal supply being found at a depth of 1,780 feet. The following record has been furnished by C. L. Nicholson, the driller:

Record of well at Gettysburg, S. Dak.

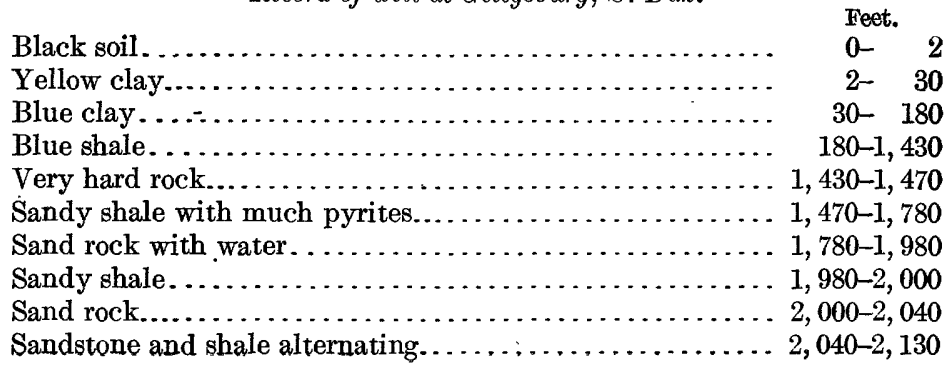


Roberts County is in the northeast corner of South Dakota. It comprises a wide area of lowlands adjoining Bigstone Lake and Lake Traverse and its southwestern and west-central portions extend far up the slopes of the coteau. It is underlain mainly by Pierre, Benton, and Niobrara, but the granite comes to the surface in "the southeast corner. Very few data are available as to the geology of this county, especially regarding the distribution of the Dakota sandstone. No reports of deep wells in this county have been received. The 465-foot well at Browns Valley, on the opposite side of the river, in Minnesota, has a small pressure, presumably from the thin eastern edge of the Dakota sandstone lying on granite. This and the wells at Milbank, in the county adjoining on the south, afford assurance that flows may be expected on the lower lands of eastern Roberts County. The scanty flow of salty water at Veblen, in the northeast corner of Marshall County, suggests that the conditions will not be favorable for satisfactory supplies in the northwestern portion of Roberts County.

\section{ROSEBUD INDIAN RESERVATION.}

The Rosebud Indian Reservation comprises about 5,000 square miles of the plains lying south of White River, in the south-central portion of South Bakota. The greater part of the surface is rolling, with numerous deep valleys draining into White River to the north or Missouri River to the east. The reservation also contains the headwaters of Ponca Creek and Keyapaha River. The altitudes range from somewhat less than 1,200 feet on Missouri River to 3,000 feet in the southwest corner of the reservation.

The predominating formation of the region is the Pierre shale, overlain in the higher lands of the south by White River and Arikaree deposits, and cut through by Missouri River, which exposes the underlying Niobrara chalkstone along the east side of the reservation. The beds lie nearly horizontal, dipping very slightly to the west. Beneath the Pierre shale there is the usual succession of Niobrara chalkstone, Benton shales, and Dakota sandstone. In the lower lands to the east this sandstone is less than a thousand feet below the surface, but to the west it lies deeper, and, in the higher lands southwest of the Rosebud Agency, is at a depth of at least 2,500 feet. On White River, in the northwest corner of the reservation, the depth is probably about 1,900 feet.

Only one boring has been sunk in this area. It is located on the highlands at the head of Oak Creek, on the divide between the White River and Keyapaha drainage. It was sunk by the Indian Bureau with the expectation of obtaining a flow that would fill some of the creeks with water, but this expectation was not realized. A depth of 
2,500 feet was attained, 'and the Dakota sandstone was penetrated for several hundred feet, yielding water in moderate volume which rose within 500 or 600 feet of the surface. The ground at the well has been found by recent leveling to have an altitude of 2,626 feet, so that the water level at the well is between 2,026 and 2,126 feet above sea level. This head indicates that flows might be expeeted all along the White River valley and for some distance up the adjoining valleys and slopes, probably to the western margin of the reservation. This altitude of head probably increases slightly to the west, toward the Black Hills, and decreases to the east, as shown by the experience of wells along the Missouri River valley. Adjacent to this valley there is sufficient head to afford flows far up the slopes, but not on the wide areas of high plains in the eastern portion of the reservation. (See Pl. XI.)

The Rosebud well was put down in 1895, 1896, and 1897, and, while a costly experiment, has thrown very important light on underground-water conditions over a wide area of south-central South Dakota. The depth of the boring is 2,500 feet. It was cased with 8 -inch casing to 2,145 feet, and below that with 6 -inch casing. The following record is based on samples kindly furnished by Mr. Wright and Doctor McChesney, the Indian agents:

\section{Record of the Rosebud well, Rosebud Indian Reservation.}

\begin{tabular}{|c|c|}
\hline & Feet. \\
\hline 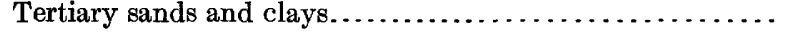 & $0-350$ \\
\hline Dark-gray shales............... & $350-1,390$ \\
\hline Water which rose to $-1,140$ feet $\ldots \ldots$. & 1,390 \\
\hline Light-gray shales, with water at 1,490 feet & $1,390-1,550$ \\
\hline Light-gray limy shales................... & $1,550-1,730$ \\
\hline Dark shales........................... & $1,730-1,860$ \\
\hline Sandstone and limestone..$\ldots \ldots \ldots \ldots \ldots \ldots$ & $1,860-1,880$ \\
\hline , with water rising to -600 feet....... & $1,880-1,885$ \\
\hline elow $\ldots \ldots \ldots \ldots \ldots \ldots \ldots \ldots \ldots \ldots$ & $1,885-1,920$ \\
\hline Har & $1,920-1,950$ \\
\hline with thin limestone bed at 2,060 feet. & $1,950-2,075$ \\
\hline - & $2,075-2,100$ \\
\hline hard at top..... & $2,100-2,140$ \\
\hline ( & $2,140-2,150$ \\
\hline 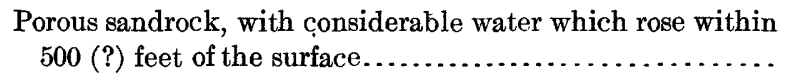 & $2,150-2,175$ \\
\hline Unknown.. & $2,175-2,210$ \\
\hline Shale. & $2,210-2,240$ \\
\hline andstor & $2,240-2,290$ \\
\hline & $2,290-2,292$ \\
\hline $\begin{array}{l}\text { ine-grained sandstone with some shale and pyrites; water } \\
\text { mainly at } 2,295 \text { feet } \ldots \ldots \ldots \ldots \ldots\end{array}$ & \\
\hline
\end{tabular}

The upper 350 feet belong to the Arikaree formation and the White River group. The Pierre shale underlies these formations to a depth of about 1,550 feet, having thus a thickness of 1,200 feet, to the 
Niobrara chalkstone, which appears to begin at a hard limestone layer and to comprise nearly 200 feet of limy clays, extending to a depth of 1,730 feet. The underlying shales with thin beds of sandstone and limestone belong to the Benton group, which extends to at least 2,100 feet, where thick beds of sandstone begin and continue thence to the bottom, probably representing the Dakota sandstone for the lower 200 feet, at least. The volume of water in the sandstone in this well was not thoroughly tested, but it was the idea of the drillers that it was moderate, which is surprising when the large flows in some of the wells to the north and east are considered. The sandstones in the well are very fine grained, and on this account much less permeable than in some other localities. It is unfortunate that this boring was not continued through the Dakota sandstone to test the water pressure in the lowermost beds and to explore underlying formations in which water might be expected to have still greater head.

It is probable that this region is underlain by the eastern extension

- of some of the sedimentary formations older than the Dakota sandstone, which are so prominent in the Black Hills.

\section{SANBORN COUNTY.}

Sanborn County lies in the James River valley and comprises a very important portion of the Dakota artesian basin. It is underlain by the Pierre shale, Niobrara chalk, Benton shales and sandstones, and Dakota sandstone, lying on a floor of quartzite and granite, all dipping gently to the north. The surface is deeply covered by drift and superficial deposits, and there are no outcrops of the underlying rock, all knowledge of them being derived from well records. The Pierre shale underlies the northern portion of the county only, the drift in the southern portion being underlain by the Niobrara chalk.

The depth to artesian water increases at a nearly regular rate from north to south, except that in the James River valley, which is excavated to a depth of about 100 feet below the surrounding plains, the depths are correspondingly less. The Dakota sandstone, usually near its top, is the principal source of water supply, though sandstones at various horizons in the Benton group also afford flows of moderate volume. In the east-central portion of the county, about Artesian, there is an area of considerable extent in which flowing waters are obtained from the base of the drift at depths mostly from 50 to 110 feet, the water probably having its source through leakage from the upper sandstone of the Benton. This sandstone is a persistent member throughout the greater part of the region and is reached by many wells of moderate depth, especially in the district about Letcher. The depth to the Dakota sandstone averages from 340 to 450 feet along 


\section{GEOLOGY AND UNDERGROUND WATERS OF SOUTH DAKOTA.}

the southern margin of the county, increasing to 475 feet in the higher lands to the west and diminishing to less than 300 feet in the valley of James River. To the north the depth increases regularly; along the northern margin of the county it is about 750 feet on the higher lands and 700 feet in the trough of the James River valley. The waters have considerable head, the altitude of which is about 1,400 feet in the southern part of the county, 1,500 feet in the central and eastern parts, 1,600 feet about Woonsocket and farther north, and about 1,550 feet in the northeast corner. This head is indicated by a pressure of 130 pounds to the square inch at Woonsocket and of 90 to 130 pounds to the square inch in the vicinity of Letcher. At Woonsocket a flow of 1,150 gallons per minute is reported from a well 6 inches in diameter. A view of this well is given in Plate XV, which clearly shows that the water is under high pressure, for it is being jetted to a height of over 100 feet above the surface of the ground. The volume of the water varies considerably, but in general increases toward the north. The following is a list of the principal wells in Sanborn County:

Artesian wells in Sanborn County.

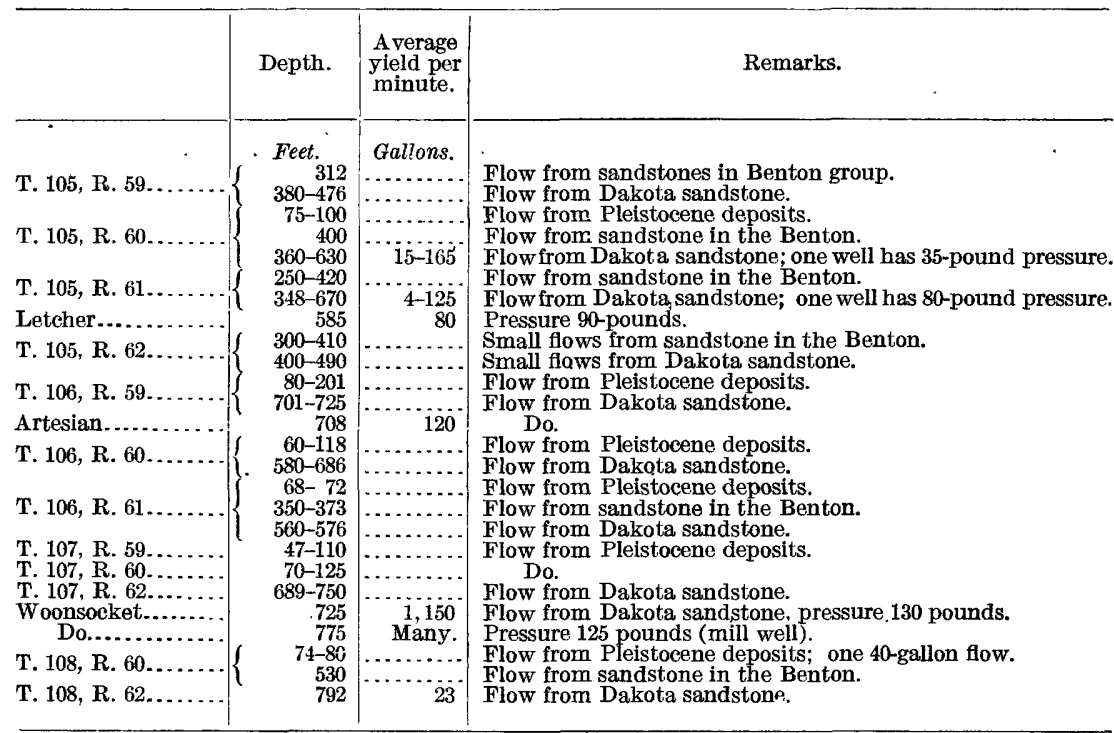

Records of some representative wells in this county are as follows:

Feet.

Yellow and blue clays............................... 0 . 25

Sand...................................... 25-45

Blue clay ....................................... $45-58$

Hardpan..................................... $58-65$

Sand....................................... $65-95$ 


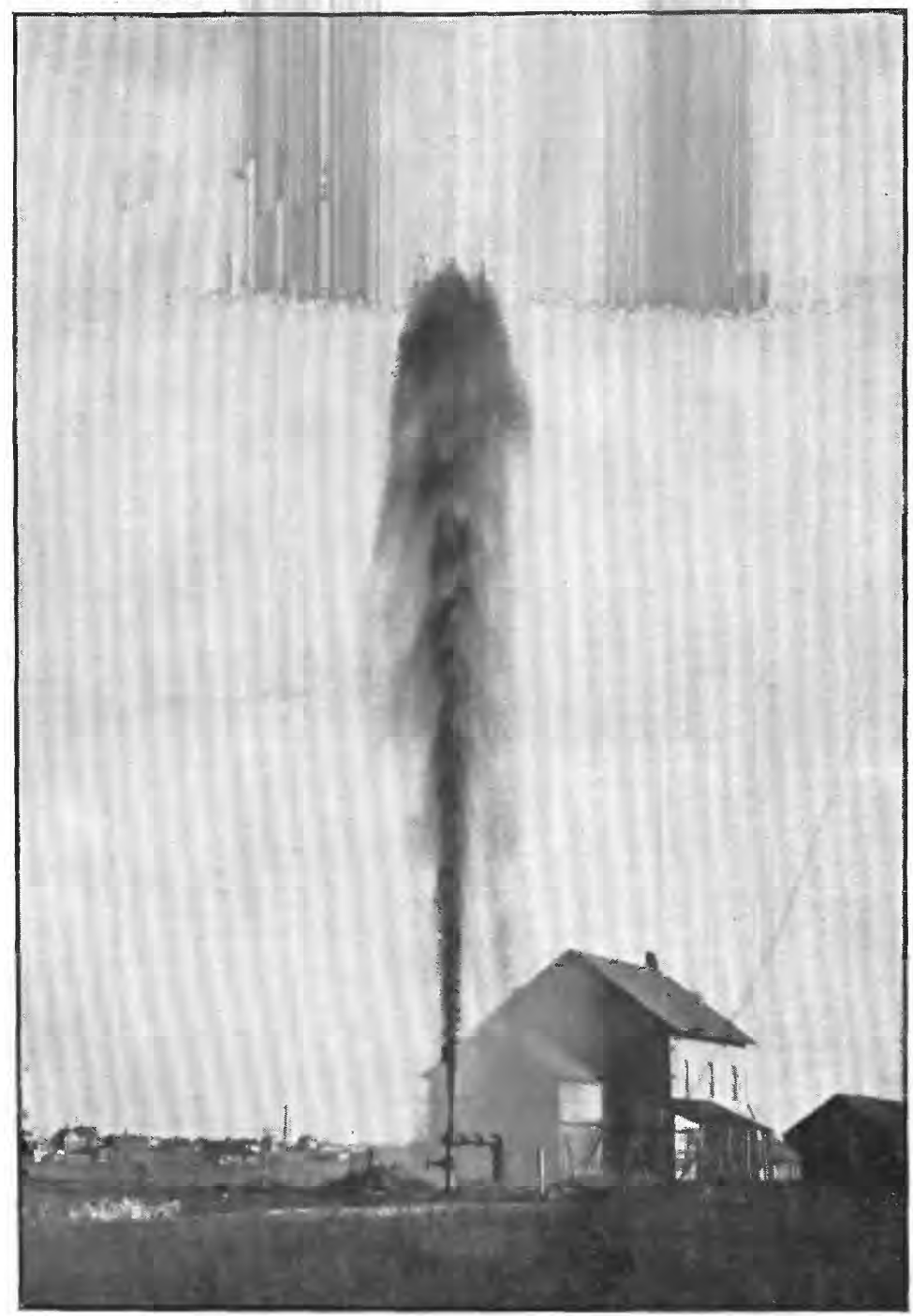

ARTESIAN WELL AT WOONSOCKET.

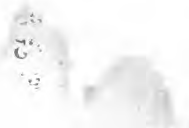





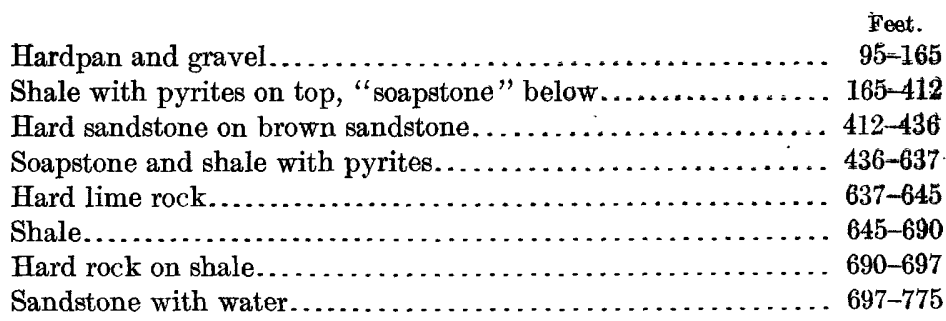

Record of well on farm of H. K. and E. O. Ashmore, near Artesian.

Drift $\quad$ Feet.

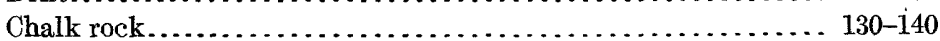

Shale............................................. 140-190

Sandstone; no water................................ 190-235

Shale, with first flow at 530 feet; layer of sand rock with water at

630 feet; rock, not very hard, at 690 feet.............. 235-690

Record of well in $N W . \frac{1}{4}$ scc. $18, T .106$, R. 5.9 .

Glacial deposits.

Feet.

$0-130$

Chalk

$130-140$

Shale.

$140-200$

Sandstone.

$200-262$

Shale. At 525 feet, sandstone with first flow.

$262-525$

Shale.

Sandstone with second flow

$626-630$

Shale.

$630-699$

Sandstone

699-701

Apparently the first two flows in this well are from the thin sandstones in the Benton group, and, in fact, characteristic Benton fossils were obtained near its bottom.

Record of Ryan well at Letcher.

(?)

Chalk (Niobrara) ............................. 100 170

Sandstone................................... 170-200

Shale........................................ 200-300

Sandstone with first flow........................... 300-314

Shale............................................ 314-513

Hard sandstone. . . . . . . . . . . . . . . . . . . . . . . . . . . . . 513-521

Sandstone, with 125-gallon flow.................... 521-561

In this well the Dakota sandstone evidently begins at a depth of .513 feet, and the usual first flow is found in the second sandstone in the Benton at 300 feet. The sandstone at the top of the Benton group at 170 feet did not yield a flow. 


\begin{tabular}{|c|c|}
\hline \multirow{2}{*}{\multicolumn{2}{|c|}{ Record of city well at Artesian. }} \\
\hline & \\
\hline Drift deposits. $\ldots \ldots \ldots \ldots \ldots \ldots \ldots \ldots \ldots \ldots$ & \\
\hline & $63-123$ \\
\hline 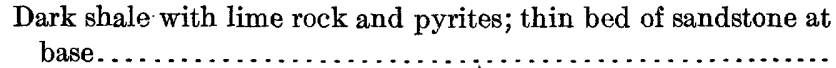 & $123-250$ \\
\hline ark shale & $250-675$ \\
\hline andstone, with 50-gallon flow. & $675-680$ \\
\hline ard sandstone (?) $\ldots \ldots \ldots \ldots$ & $680-684$ \\
\hline ndstone, with 120 -gallon flow & $684-708$ \\
\hline
\end{tabular}

\section{SPINK COUNTY.}

Spink County is in the James River valley and consists mostly of a level plain, with an average altitude of about 1,300 feet, traversed by the shallow valleys of the river and the creeks. The surface is mantled with drift deposits, mostly stratified, but presenting a few morainal hills. The underlying formations are the Pierre, Niobrara, Benton, and Dakota, lying on granite and possibly quartzite in some places. The Niobrara appears to be represented by shale or by chalk so mixed with clay that its distinctive features are not recognized by the well borers. The entire county lies within the Dakota artesian basin, and its waters are tapped by numerous wells, probably 75 in all. They average about 900 feet in depth. Most of them obtain water from the upper portion of the Dakota sandstone, though a few of the deeper ones reach lower strata. The beds lie nearly horizontal but rise slightly to the southeast, owing to the presence of an underground ridge of quartzite and granite which extends across the southeast corner of the county. Some of the wells in the vicinity of this ridge which have not found satisfactory water supplies have been sunk to the granite in the hope of obtaining greater volume. The waters have high pressure, averaging over 100 pounds to the square inch throughout the county, rising to 165 pounds at Mellette and to 177 pounds at Redfield, and diminishing to 50 pounds in the Glidden well, a short distance northwest of Hitchcock, where granite was reached. The principal features of the wells in Spink County are given in the following list: 
Artesian wells in Spink County.

\begin{tabular}{|c|c|c|c|c|}
\hline $\begin{array}{l}\text { Town- } \\
\text { ship. }\end{array}$ & Range. & Depth. & $\begin{array}{l}\text { Average yield } \\
\text { per minute. }\end{array}$ & Remarks. \\
\hline $\begin{array}{l}118 \\
119 \\
119 \\
119 \\
119 \\
119 \\
119 \\
120 \\
120 \\
120 \\
120 \\
120\end{array}$ & $\begin{array}{l}62 \\
63 \\
64 \\
65 \\
61 \\
61 \\
\\
62 \\
\\
63 \\
64 \\
64 \\
64\end{array}$ & 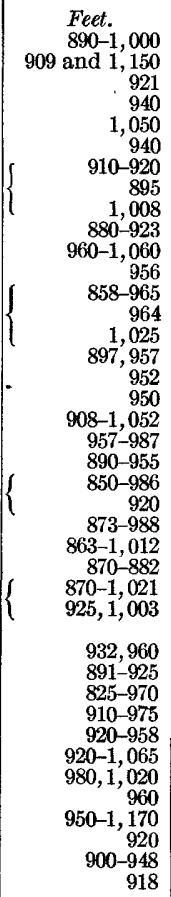 & 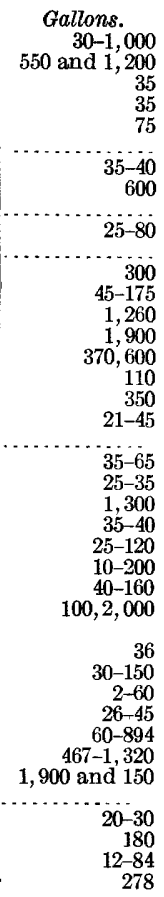 & $\begin{array}{l}\text { Pressure } 125 \text { and } 150 \text { pounds. } \\
\text { Pressure } 50 \text { pounds. } \\
\text { Pressure } 87 \text { pounds. } \\
\text { Blaine well, Frankfort. } \\
\text { Town well, Frankfort. } \\
\text { Redfield city wells Nos. } 2 \text { and } 3 . \\
\text { Institution for feeble-minded. } \\
\text { Pressure } 177 \text { pounds (Redfield town well). } \\
\text { Well of Hassell \& Myers, Redfield. } \\
\text { Pressure } 122 \text { and } 112 \text { pounds (Doland town wells). }\end{array}$ \\
\hline
\end{tabular}

The records of borings in Spink County are very uniform. There are 800 feet or more of shales, representing the Pierre, Niobrara, and Benton formations, the Benton usually containing some thin beds of sandstone and limestone, with small flows. The Dakota sandstone has not been penetrated deeply in the northern portion of the county. At its top there is usually a thick mass of sandstone and in places bodies of shale. In the southern part of the county, where the crystalline rock has been reached, the sandstone was found to be of variable thickness, being about 200 feet thick in the Glidden well, a short distance northwest of Hitchcock, and only 150 feet in the Budlong well, 5 miles northeast of Hitchcock. In both of these places the sandstone occurs in thin layers separated by considerable shale, mostly of light color, in marked contrast to the conditions in other wells not far distant in which thick masses of sandstone were penetrated-for instance, in the boring at Frankfort, which went through 200 feet of sandstone in one nearly continuous mass. 


\section{STANDING ROCK INDIAN RESERVATION.}

The Standing Rock Indian Reservation is in north-central South Dakota, between the Cheyenne River Reservation and the North Dakota boundary line. It extends from Missouri River westward to longitude $102^{\circ}$. It lies entirely in the valley of Grand River but includes a large area of adjacent slopes. The higher lands consist of the Fox Hills sandstone and overlying lignite-bearing sandstones and shales. The lower lands along Grand River below the mouth of Flint Creek and along the Missouri are underlain by the Pierre shale. This shale has a thickness of about 1,000 feet and is underlain by a regular succession of Niobrara and Benton shales and Dakota sandstone. The Dakota has not been reached by any wells in the vicinity of the reservation but it yields a large flow at the well at Cheyenne Agency, 30 miles to the south, and in the well at Selby, Walworth County. The pressures in these wells indicate that the water in the Dakota sandstone has sufficient head to rise to an altitude of 2,000 feet in the eastern portion of the Standing Rock Reservation, and the gradient is such, as shown on Plate XI, that the altitude of head is probably about 2,300 feet at the southwest corner of the reservation. These factors indicate that flows should be expected along the lower portion of the Grand River valley, all the way across the reservation, and also along Missouri River and for some distance up the adjacent slopes. The depth to the top of the Dakota sandstone is probably about 1,500 feet in the southeast corner of the reservation, but it increases gradually to the north and more rapidly to the west. In the Grand River valley at longitude $102^{\circ}$ the depth is probably about 2,500 feet.

\section{STANLEY COUNTY. ${ }^{a}$}

Stanley County comprises an area of nearly 5,000 square miles in the central part of South Dakota, extending west from the Missouri River valley south of Cheyenne River, and in its southwestern portion reaching White River. All of it is underlain by the Pierre shale; small areas of the overlying Fox Hills sandstone lie west of Grindstone Buttes and along the eastern margin of the White River formation in badlands in the southwest corner. Under the Pierre shale there is the usual succession of Niobrara chalk, Benton shales, and Dakota sandstone, underlain to the east by granite or quartzite and probably overlapping to the west onto the eastern extension of some of the earlier Mesozoic and Paleozoic rocks that extend underground from the Black Hills region. Under the greater part of this county the beds appear to lie nearly level or to dip gently to the west. 
The depth to the Dakota sandstones is about 1,150 feet at Pierre and it gradually increases as the land rises westward. In the northeast corner of the county, at the mouth of Cheyenne River, the depth is probably about 1,250 feet. On this river in the northwest corner of the county the depth is probably nearly 2,000 feet, or possibly more, if there is any unusual thickening of the formations in this direction. In the southwest corner of the county, on White River, the depth is probably somewhat greater and reaches very nearly 2,500 feet, and on the head of Bad River this amount must be considerably exceeded. On the high divide between the rivers the depths are from 300 to 500 feet greater than in the valleys.

To judge by the pressure of the water in the wells at Pierre and the probable increase in head to the west, flowing water may be expected in the'large valleys and part way up the slopes all across the county.

Two wells have recently been sunk in this county along the line of the western extension of the Chicago and Northwestern Railway from Pierre. One is at Wendte, 20 miles up the Bad River valley west of Pierre, and the other at Nowlin, 55 miles west of Pierre.

Wendte.-The well at Wendte station is 3 inches in diameter (2 inches at the bottom) and 1,395 feet deep. It yields a flow of 90 gallons a minute and considerable gas comes up with the water, which has a temperature of $108^{\circ}$. The first 1,280 feet were shale with a few strata of limestone in the lower portion, and from 1,280 to 1,395 feet two or three thin strata of sandstone were penetrated. The gas began at a depth of 1,280 feet.' This well cost $\$ 1,592$. An analysis of the water, by G. M. Davidson, is as follows:

Analysis of water from artesian well at Wendte.

\begin{tabular}{|c|c|}
\hline [Hypothetical compounds.] & $\begin{array}{c}\text { Grains per } \\
\text { gallon. }\end{array}$ \\
\hline Carbonate of lime......... & - 1.68 \\
\hline Carbonate of magnesia.......... & 1. 13 \\
\hline Oxides of iron and aluminum & .07 \\
\hline 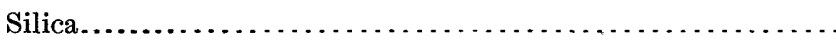 & .90 \\
\hline Alkaline chlorides..................... & . 133.22 \\
\hline Alkaline sulphates................ & Trace. \\
\hline Alkaline carbonates................... & 67.93 \\
\hline
\end{tabular}

The water is poor for locomotive use. It will not scale, but will cause foaming.

Nowlin.-The well at Nowlin station is 1,842 feet deep, with a 3 -inch casing and 2-inch screen in bottom. It has a flow of 125 gallons a minute, a pressure of about 72 pounds, and a temperature $121^{\circ}$. It passed through 1,770 feet of shale with some limestone, and from 1,770 feet to the bottom was in Dakota sandstone. A small first flow 
was found at a depth of about 1,600 feet. Much gas was encountered. The cost was $\$ 4,605$. The altitude of the well is 1,964 feet and the pressure indicates that the altitude of the head of artesian water in this vicinity is 2,130 feet. Analysis of the water, by G. M. Davidson, is as follows:

Analysis of water from artesian well at Nowlin.

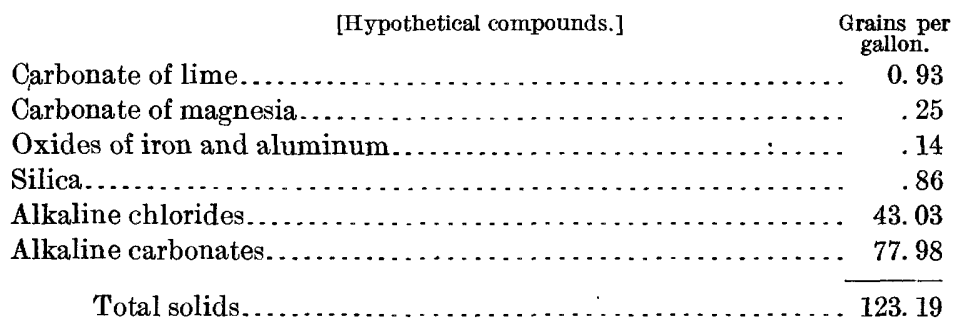

This is a poor water for boiler use. It will not form scale, but will cause foaming.

SULLY COUNTY.

Sully County extends eastward from Missouri. River part way across the high ridges lying between Okobojo and Médicine Knoll creeks. The highlands are covered more or less thickly with glacial drift and the entire region is underlain by a thick mass of Pierre shale. The Dakota sandstone lies deep, even in the Missouri Valley, but has been reached by a number of wells and found to contain large volumes of water having sufficient head to afford a flow throughout the area. The following list indicates the principal conditions under which the waters are obtained:

Artesian wells in Sully County.

\begin{tabular}{|c|c|c|c|c|c|}
\hline & Depth. & $\begin{array}{c}\text { Depth } \\
\text { to } \\
\text { water. }\end{array}$ & $\begin{array}{c}\text { Diame- } \\
\text { ter. }\end{array}$ & $\begin{array}{c}\text { Average } \\
\text { yield } \\
\text { per } \\
\text { minute. }\end{array}$ & Remarks. \\
\hline Mr. Wadleigh, SE. $\frac{1}{4}$ sec. 32 , T. 113 , R. 79. & $\begin{array}{l}\text { Feet. } \\
1,565\end{array}$ & $\begin{array}{l}\text { Feet. } \\
1,565\end{array}$ & $\begin{array}{r}\text { Inches. } \\
3-2\end{array}$ & $\underset{200}{\text { Gallons. }}$ & Water saline. \\
\hline Oneida town well, NW. $\mathrm{N}$, sec. 11, T. & 1,717 & $\left\{\begin{array}{l}1,560 \\
1,630\end{array}\right.$ & \}$\quad 2$ & 85 & $\left\{\begin{array}{c}\text { Pressure } 21 \text { pounds; hard; } \\
\text { no gas. }\end{array}\right.$ \\
\hline $\begin{array}{l}\text { Pearl Township well No. } 2 \text {, SE. } \frac{1}{4} \text { sec. } 3 \text {, } \\
\text { T. 115, R. 79. }\end{array}$ & 1,645 & 1,640 & 2 & 20 & Water soft, warm, gassy. \\
\hline $\begin{array}{l}\text { Pearl Township well No. } 1 \text {, NW. } \frac{1}{4} \\
\text { NE. } \frac{1}{4} \text { sec. } 28, \text { T. } 115, \text { R. } 79 \text {. }\end{array}$ & 1,781 & 1,600 & 2 & 65 & $\begin{array}{l}\text { Pressure } 25 \text { pounds; soft; } \\
\text { gassy. }\end{array}$ \\
\hline A. Hallam, sec. 19, T. 116, R. $78, \ldots \ldots$. & 1,595 & 1,595 & 2 & 85 & $\begin{array}{l}\text { Pressure } 65 \text { pounds; soft; } \\
\text { gassy. }\end{array}$ \\
\hline
\end{tabular}


The following records of Sully County wells have been furnished:

Record of deep well in SE. $\frac{1}{4}$ sec. 32, T. 113, R. 79, Sully County.

Black soil and gravel.

Feet.

Yellow clay, gravelly.

$0-2$

Blue clay, part till..

$2-30$

Blue shale, with slabs.

$30-190$

Black shale, with some slabs.................... $\quad 610-680$

Coarse gravel ................................ $\quad 680-720$

Shale (?).................................. 720 . 783

Very hard sandstonle, with gas.................... $783-785$

Blue shale, with "shells" of limestone.............. $785-1,000$

Gray shale................................. 1,000-1,060

Blue shale, with some limestone and slate............ 1,060-1,400

Hard stone ................................ 1, 400-1,402

Shale and sandy streaks, with first flow at 1,402 feet. . . . 1, 102-1, 510

Fine sand rock, with hard shells; second flow, gas...... 1, 510-1, 565

Record of deep well in NW. $\frac{1}{4}$ sec. 11, T. 114, R. $7 \gamma^{\circ}$, Oneida.

Black soil

Feet.

Yellow clay

$0-3$

Blue clay and gravel pockets..................... $34-170$

Blue shale, with hard shells . . . . . . . . . . . . . . . . . 170 950

Black shale, with slate. ....................... $950-1,200$

Gray shale................................ 1, 200-1,260

Blue shale. . . .......................... 1,260-1,400

Shảle, sandy streaks.......................... 1,400-1, 560.

Sandstone, with a few hard "shells;" first flow .......... 1, 560-1, 630.

Sand rock; second flow....................... 1, 630-1,717.

Record of well No. 1, Pearl Township, Sully County.

Black soil

Feet.

Yellow clay

$0-\quad 3$

Blue clay

$3-34$

Blue shale, with slabs 2 to 20 feet thick............. 210 968

Shaly limestone............................. 968 970

Shale...................................... $970-1,020$

Limestone..................................... 1,020-1,028

Shale................................... 1,028-1,080

Blue shale, streaks of gray shale, and limestone........ 1,080-1, 585

Sandstone; water, flows not definite............. 1,585-1,780

Very hard rock.......................... 1,780-1,781

Record of deep well No. 2, Pearl Township, Sully County.

Feet.

Black soil................................ $1^{\frac{1}{2}}$

Yellow clay.................................. $\quad 1_{\frac{1}{2}}-\quad 32$

Blue clay (till and Pierre?)..................... $32-200$

Sand..................................... $200-210$

Shale, with hard layers..................... $210-1,240$

"Many hard layers of limestone"............... 1, 240 -1,265 
Feet.

Hard cap rock............................ 1, 265 -1,295

Shale, with few "shells" (i. e., hard streaks, some gray

below, blue and black above)................ 1,295 -1,525

Sandstone and water; no flow................... 1,525 -1,531

Alternating shale and sand rock, 5 to 10 foot layers; water.. 1, $531-1,600$

Sandstone and flow of water, with gas............... 1,600 -1, 645

Very hard stone; probably granite................ 1,645 -1,646

TURNER COUNTY.

Turner County comprises a portion of the Vermilion River valley and the adjoining prairies to the summit of Turkey Ridge. Its surface is mostly covered with glacial drift, which lies in thick masses on the higher lands. The Sioux quartzite rises in the northern and northeastern portions of the county, where it is exposed at a number of points and reached by numerous wells of moderate depth. To the south the drift is underlain by the Niobrara chalkstone and probably by more or less Pierre shale in Turkey Ridge. The Benton group and Dakota sandstone underlie the central and southern portions of the county and abut against the slope of Sioux quartzite, the edge of the younger formations probably extending for several miles northwestward beyond the margin of the Dakota.

Owing to the diminished pressure of water in the Dakota sandstone, artesian flows from this source are available in this county only in the southeast corner of the Vermilion River valley. There are, however, at numerous localities small flows from the base of the drift at depths mostly of 50 to 100 feet. A number of deep wells which have been sunk in Turner County have found in the Dakota sandstone water that rises several hundred feet, but not sufficiently to flow. One well 4 miles west by south of Hurley has a depth of 513 feet, passing through drift to 80 feet; chalkstone from 80 to 150 feet; Benton shales from 150 to 417 feet; and Dakota sandstone to the bottom, which apparently is in Sioux quartzite. A well at Hurley passes through 35 feet of drift, 100 feet of chalk rock, and 265 feet of Benton to the top of the Dakota sandstone. North of this place are a number of moderately deep wells that apparently obtain water supplies from sandstone at the base of the chalk rock, which is underlain at no great depth by the Sioux quartzite.

\section{UNION COUNTY.}

The Dakota sandstone appears to underlie all of Union County, outcropping to the southeast in the bluffs on the Iowa side, near the mouth of Big Sioux River. The sandstone has been reached by a number of wells of moderate depth in the western portion of the county, but the head of the artesian water is so low that there are no surface flows. 
An unsuccessful deep boring at Elk Point had the following record:

\begin{tabular}{|c|c|}
\hline Loamy clay. & $\begin{array}{l}\text { Feet. } \\
0-20\end{array}$ \\
\hline uicksand and good water... & $20-21$ \\
\hline Clay...$\ldots \ldots \ldots \ldots \ldots \ldots \ldots$ & $21-51$ \\
\hline Sand; irony water. . . . . . . . . . & $51-61$ \\
\hline Clay $\ldots \ldots \ldots \ldots \ldots \ldots \ldots \ldots \ldots \ldots \ldots \ldots$ & $61-101$ \\
\hline Sand and gravel (water) $\ldots \ldots \ldots \ldots \ldots \ldots$ & $101-111$ \\
\hline 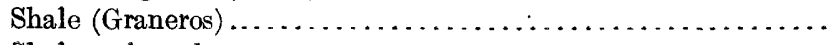 & $111-115$ \\
\hline 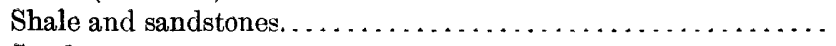 & $115-330$ \\
\hline 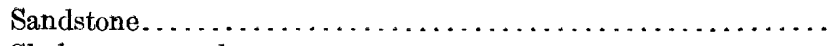 & $330-460$ \\
\hline hale; some sand..................... & $460-545$ \\
\hline Lard white rock (limestone $?) \ldots \ldots \ldots \ldots \ldots$ & $545+560$ \\
\hline
\end{tabular}

The Dakota sandstone probably extends about 200 to 545 feet in this well.

WALWORTH COUNTY.

Walworth County extends eastward from Missouri River and, except for a narrow strip of bottom land, consists of highlands with altitudes of 1,800 feet to slightly over 2,000 feet. The altitude of the river bottom is about 1,500 feet, being 1,552 feet at Evarts. The county is underlain by the Dakota sandstone, which has an altitude above sea level of about 300 feet in the eastern part and 150 feet in the western part.

A well recently sunk at Selby reached the Dakota sandstone at a depth of 1,747 . feet, penetrated it to a depth of 1,897 feet, and obtained a flow of 17 gallons per minute, under sufficient pressure to rise about 38 feet above the surface, or to 1,915 feet above sea level. The first 90 feet in the well are glacial drift, below which are 1,662 feet of shales, comprising the Pierre, Niobrara, and Benton. The diameter of the well is $1 \frac{1}{4}$ inches inside. The water is alkaline and tepid, and contains sufficient gas to afford a constant flame several feet high. The principal flow was from a depth of 1,880 feet. This well indicates that artesian waters are available in Walworth County up to altitudes slightly above 1,900 feet in the vicinity of Selby, with the head diminishing somewhat to the east, as indicated by the lower pressure at Ipswich, and increasing to the south, as shown by the head of 1,974 feet in the Gettysburg well, in the adjoining county. These facts would indicate that about half of Walworth County is sufficiently low for a flow; the ridge north of Swan Creek, between Selby and Byron, and some smaller areas are too high for flowing wells.

\section{YANKTON COUNTY.}

Yankton County extends northward from Missouri River into a region of rolling plains traversed by the valley of James River. The higher lands are covered by glacial drift and the underlying forma- 
tions appear only in bluffs along Missouri River. Nearly all of the area is underlain by the Niobrara chalkstone, but this formation is cut through by the Missouri below the mouth of the James, revealing the underlying Carlile shale of the Benton group. The entire county is underlain by the Dakota sandstone, which contains a large volume of water under pressure sufficient to afford flowing wells in all the townships except on the divide between. James River and Clay Creek and in the northeast corner of the county. Along the bottom lands of Missouri and James rivers these waters have been developed by numerous wells which obtain flows at moderate depths. There is considerable variation in the volume of water, one well in Yankton 493 feet deep having at one time produced 3,000 gallons per minute from an 8-inch casing, while others in other portions of the district yield very much less, owing to locally increased compactness of the water-bearing rock and diminution of pressure. The decrease of pressure is gradual and regular from west to east across this county, owing to the fall of hydraulic head toward the zone of leakage in the area in which the Dakota sandstone is at or near the surface in Union County and farther south. The following list gives the principal features of the deeper wells in this county from which reports have been received:

Artesian wells in Yankton County.

\begin{tabular}{|c|c|c|c|c|}
\hline $\begin{array}{l}\text { Town- } \\
\text { ship. }\end{array}$ & Range. & Depth. & $\begin{array}{c}\text { Average } \\
\text { yield } \\
\text { per } \\
\text { minute. }\end{array}$ & Remarks. \\
\hline 93 & 54 & $\begin{array}{l}\text { Feet. } \\
250-450\end{array}$ & Gallons. & Pressure 10 to 60 pounds. \\
\hline 93 & 55 & $212-483$ & $36-140$ & Pressure 15 to 30 pounds. \\
\hline 93 & ob & 520,521 & $\begin{array}{r}95,350 \\
3,000\end{array}$ & $\begin{array}{l}\text { Pressure } 45 \text { to } 49 \text { pounds; several flows. } \\
\text { Excelsior Mill, Yankton; 8-inch; several flows; pressure }\end{array}$ \\
\hline & & $\begin{array}{l}595 \\
625 \\
942\end{array}$ & $\begin{array}{r}1,450 \\
880\end{array}$ & $\begin{array}{l}\text { Fountain Roller Mill, Yankton; } 6 \text {-inch; pressure } 48 \text { pounds. } \\
\text { City well, Yankton; 6-inch; pressure } 18 \text { pounds. } \\
\text { City well, deepened; no additional flow. }\end{array}$ \\
\hline 93 & $55-56$ & $\begin{array}{l}672 \\
524\end{array}$ & $\begin{array}{r}165 \\
2,600\end{array}$ & $\begin{array}{l}\text { Asylum well near Yankton. } \\
\text { College Hill, Yankton; 2-inch well. }\end{array}$ \\
\hline & & 500 & 1,300 & Cement company's well, near Yankton; 5 flows; 5 -incit wet ; \\
\hline & & $\begin{array}{r}521 \\
400-475\end{array}$ & $\begin{array}{r}350 \\
6-95\end{array}$ & Whiting Nursery, Yankton; 3-inch well; pressure 49 pounds. \\
\hline 93 & 57 & 530,585 & Many. & Pressure 30 pounds or more. \\
\hline 94 & 54 & $268-510$ & $5-150$ & Numerous small wells; pressure 12 to 60 pounds. \\
\hline $\begin{array}{l}94 \\
95\end{array}$ & $\begin{array}{l}55 \\
54\end{array}$ & $\begin{array}{l}435-688 \\
545,580\end{array}$ & $\begin{array}{r}3-100 \\
8\end{array}$ & Three flows; pressure 6 pounds. \\
\hline 95 & 55 & $\left\{\begin{array}{l}535-554 \\
266\end{array}\right.$ & Many. & $\begin{array}{l}\text { Several flows. } \\
\text { First flow }\end{array}$ \\
\hline $\begin{array}{l}95 \\
96\end{array}$ & $\begin{array}{l}56 \\
55\end{array}$ & $\begin{array}{l}544-640 \\
145-590\end{array}$ & $\begin{array}{r}43-80 \\
\text { Several. }\end{array}$ & Pressure 15 pounds. \\
\hline $\begin{array}{l}96 \\
96\end{array}$ & $\begin{array}{l}56 \\
57\end{array}$ & $\begin{array}{l}700 \\
505\end{array}$ & Many. & $\begin{array}{l}\text { No flow. } \\
\text { Two flows. }\end{array}$ \\
\hline
\end{tabular}

One of the noticeable features in this table is the great variation in the volume of water in wells in the vicinity of Yankton. This is particularly shown by the relatively small volume afforded by the 
Yankton city well. In order to obtain a larger supply, this well was deepened some years ago from 625 to 942 feet, but no material increase of flow was obtained. It is stated that the last 44 feet were in crystalline "bed rock." In all the deeper wells several flows are found in sandstone beds occurring at intervals in alternation with clay beds in the Dakota. The thickness and position of these sandstone strata appear to be very variable. In general the deeper seated waters are more uniform in tolume and furnish large supplies, mainly in Yankton and vicinity. Water for local use is found at higher horizons in mañy s̄mall wells, which are sunk only sufficiently deep to reach a moderate supply.

In Yankton the waters are used to a considerable extent for power in mills, in some wells developing a pressure of 50 pounds to the square inch. The wells of the higher lands are considerably more than 600 feet deep; those on the lowlands near the river are of correspondingly less depth. The pressure varies, partly on account of differences of altitude in the wells, but gradually decreases toward the east, as above explained. It is claimed that the pressure in the wells is diminishing, and as a very large amount of water has been flowing from them for many years doubtless this is the case in portions of the area where wells are numerous. At one of the mills in Yankton the original pressure was 45 pounds, but after the water had been flowing freely for two years it was found to be losing pressure. The practice of shutting off the flow when the mill was not running was then begun, since when the pressure has remained constant at 37 pounds. The apparent diminution of pressure in many of the wells is due to the caving in of the lower portion, which cuts off the lower and stronger flows, and in some it is due also to the fact that the pipes are corroded and permit the water to escape underground into strata where the pressure is less.

The geologic conditions in the wells of Yankton County are very similar to those of Bonhomme County, most of the borings beginning in the Niobrara chalk rock, passing into the Benton group at a depth of 50 to 200 feet, and going through 300 feet of this group to the Dakota sandstone. Some typical sections are as follows:

Record of city well at Yankton.

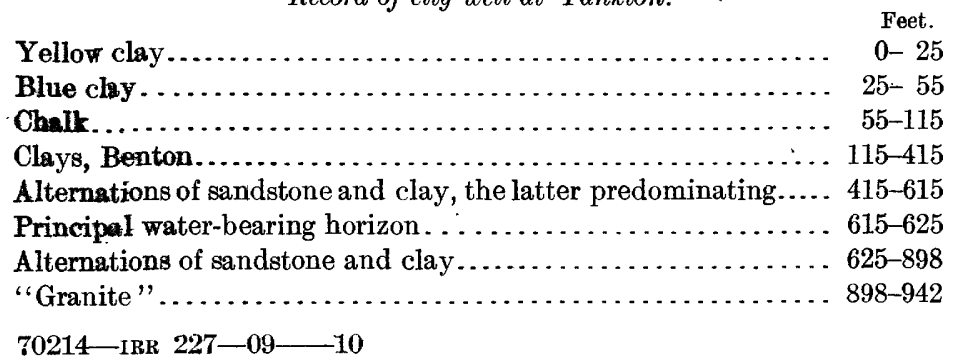


In the asylum well, 3 miles north of the city, a very similar record was observed, with a large body of water-bearing sand extending from 609 to 672 feet. It is stated that in another well at the asylum the Sioux quartzite was reached at a depth of 825 feet. At the mill well in Yankton a somewhat different series of beds was reported as the following record shows:

\begin{tabular}{|c|c|}
\hline 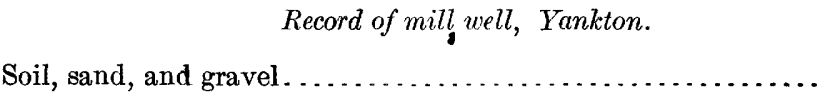 & $\begin{array}{l}\text { Feet. } \\
0-38\end{array}$ \\
\hline Chalk.............. & $38-100$ \\
\hline Shale....... & $100-126$ \\
\hline Hard rock. . . . . . . & $126-130$ \\
\hline 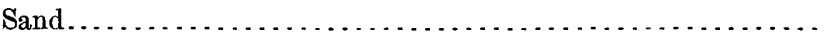 & $130-164$ \\
\hline Shale................... & $164-229$ \\
\hline Sand .............. & $229-254$ \\
\hline 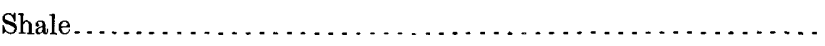 & $254-389$ \\
\hline 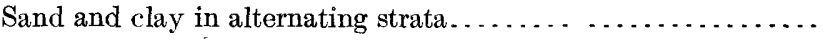 & $389-489$ \\
\hline $\begin{array}{l}\text { Water-bearing sandstone yielding a flow ot } 1,450 \text { gallons per } \\
\text { minute through a } 6 \text {-inch casing, with a surface pressure of } 48\end{array}$ & \\
\hline
\end{tabular}

It is probable that the sand beds reported between 130 and 254 feet occur in the other wells in this vicinity but were not reported. The upper sand stratum is probably the one that usually occurs a short distance below the Niobrara chalkstone, and the hard-rock stratum is doubtless a concretion such as characterizes the upper portion of the Carlile shale.

At the Yankton cement works, west of Yankton, the Dakota sandstone appears to have been reached at a depth of 450 feet and penetrated for 50 feet, yielding a flow of 1,300 gallons per minute through a 5 -inch casing.

\section{THE CONSTRUCTION AND MANAGEMENT OF ARTESIAN WELLS.}

A number of artesian wells in South Dakota which found abundant water supplies have since so deteriorated as to be of no further use. This has led many persons to believe that the life of such a well is necessarily short, and that the expense of renewing borings and casings would be so large that in the end deep wells could never be $\varepsilon$ conomical. It has not been supposed, of course, that all wells would soon give out, but the possibility has been thought to introduce a very great element of risk into well ownership. In the investigation here reported special attention was given to this particular point, and wherever a well had given out an effort was made to ascertain the causes and whether they could have been avoided. Reliable or definite statements were difficult to procure, but enough' was learned to show that in no case of failure was it inevitable from natural causes that the well should have become unserviceable if it had been 
properly built or suitably managed. The principal cause of failure was found to be the clogging up of the well with sand, clay, and other materials from below, which finally cut off the flow or reduced it to so small an amount that the well was no longer used. Another difficulty was the escape of water around the outside of the pipe in such manner that the flow of the well could no longer be controlled. Under such conditions the water would run to waste and in all probability the well would clog itself up.

Well boring is a mechanical art which has been practiced for so many.years and by so many ingenious persons that it has reached a high stage of development. As in all other industries, a large number of skilled artisans are engaged in the business, as well as, on the other hand, many incompetent persons, whose methods are crude. It would be impossible to say to what extent the failures of certain wells are due to the lack of necessary knowledge of well boring on the part of their constructors or to conditions which, at the time, could not have been foreseen. Many of the earlier wells were bored by men who were not at that time particularly skillful in their art, but who have since become expert to a high degree; but it is cause for regret that even now wells are occasionally sunk by men with.whom the success or failure of a well is largely a matter of chance. Very few persons for whom wells are bored know what is going on underground or are adequate judges of the merits of the well borer. They must trust very largely to the reputation of the well borer or to the recommendations which he brings, and should, of course; endeavor to procure an experienced and skillful man rather than a cheap contract to be executed by a borer of whose success there is doubt. There are, however, a few features of well boring that can be pointed out in such a manner as to aid persons planning to sink wells, and at the same time afford to well borers some knowledge that has proved serviceable in other regions where the art of well boring is highly developed.

In the first place, the enormous pressure, which the underground waters possess in most of the wells, must be borne in mind. This pressure is, in many wells, 500 pounds per square inch at the depth at which the water is struck. Strong casings, properly built machinery, and expert men are absolutely essential to cope with such pressures. The mere operation of boring to a depth of 500 to 1,000 feet or more is relatively simple, and its principle is presumably familiar to nearly all persons who have any interest in wells. A heavy iron rod with a steel bit on its end is dropped a few feet at the rate of 20 to 40 strokes per minute, in such a manner as to break off and churn up the material which is to be penetrated. As the hole is made, pipe for its casing is passed down, more or less closely following the bit, -particularly if the boring is in soft maferials, where casing is always necessary to hold up the walls. The pipe is lowered or gently forced down length upon length, each new length being screwed tightly into 
the coupling of the preceding one, until the water is reached. The churned-up material is either forced out by a stream of water that is pumped into the boring under considerable pressure, or baled out by a sand bucket-a short length of pipe with a large upward-opening valve in its bottom. It often happens that the casing will reach a certain point and go no farther; then a smaller size of pipe must be introduced, and in some wells it has been found necessary to decrease the size of the pipe several times before reaching the water.

With some of the improved machinery now in use this change in the size of the casing is not necessary so often as formerly, but it is

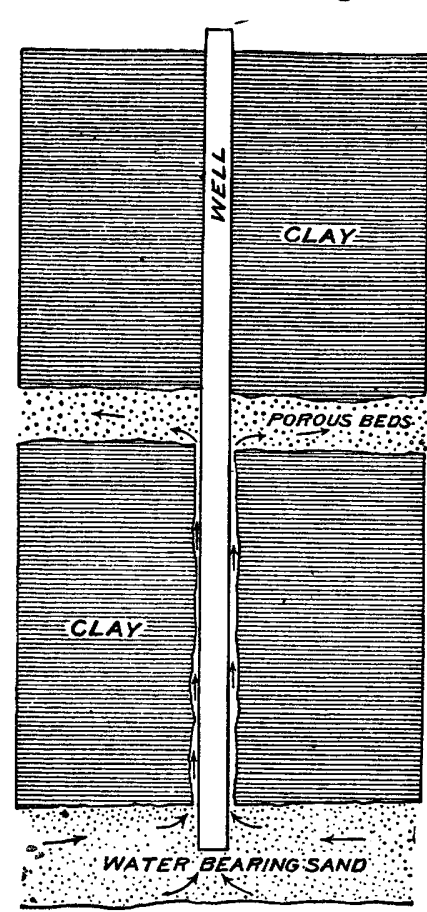

FIG. 7.-Diagram illustrating the escape of waters from a lower into a higher porous stratum along the outer side of the casing in an artesian well. expedient to make it to a certain extent for a reason that will now be explained. It is always desirable to have the casing of a well doubled for the greater part of its depth-that is, to have an outer pipe extending nearly to the water, and then to have an inner pipe extending to and into the water-bearing bed. The advantages of this arrangement are manifold, but the principal advantage is that when the inner pipe becomes in any way out of order, it may be easily withdrawn, repaired, and reinserted or replaced by a new pipe. The inner pipe will receive all the wear from suspended sand, etc., as well as the greater part of the corrosion from the water. These last two factors are not so important as might be imagined, and the life of a good, heary pipe, particularly if it is galvanized, is exceedingly long. The principal difficulties occur at the lower end of the pipe, and it is for these mainly that it is desirable to have the inner pipe removable. It is . very important to have the outer pipe rigidly fixed at its lower end in a hard bed, so that no water may reach the surface along its outer side. In a number of wells the waters have begun seeping up around the outer casing until they have finally made sufficient space to emerge in large volumes, and after that occurs the life of a well is usually soon terminated. In other wells the water has seeped up along the outer side of the well casing and found its way, in whole or in part, into some higher porous stratum, so as to decrease or totally lose its head and volume. A relation of this character is shown in figure 7 .

This is probably the reason that the pressure in numerous wells is so much less than would be expected from the depth and experience 
of wells in the surrounding district. In many wells, some of which have failed and others of which, owing to exceptionally favorable conditions, are now working satisfactorily, the casing delivering the water reaches through the cap rock but has no great extension into the water-bearing beds nor any anchorage except the thin layer of cap rock. This is a dangerous feature, and has caused clogging or displacement in a number of wells. It is always much safer to sink the inner pipe entirely through the water-bearing beds to some hard stratum lying next below them, and then sufficiently far into that stratum to hold the pipe rigidly. As it is necessary for the portion of the pipe that is in the water-bearing beds to be perforated, to admit the water, it is further desirable that this portion should be of extra heavy piping, to much more than compensate for the weakness caused by the perforations. It must be acknowledged that there is often great difficulty in managing the completion of the well after a great volume of water has been struck, but it is believed that a skillful well borer can properly insert the perforated pipe or strainer and anchor it firmly in the bed rock below. The difficulties of working in water having a high pressure are very great, and the well may be damaging itself during the delay incident to its final completion; but there are now so many expedients known to the skillful well borer that he surmounts most of these difficulties with relative ease.

It is very important in constructing and managing a well to prevent the discharge of any large volume of solid matter from the waterbearing beds, for this has been the cause of the clogging up of the greater number of wells which are now unserviceable. The perforated pipe usually obviates the possibility of extensive discharges of solid matter if the perforations are sufficiently small and if the pipe is anchored at its bottom in a hard stratum at the base of the water-bearing beds. If such an anchorage can not be made, it is advisable to introduce a valve at the open end of the pipe, although it will require no small degree of skill to insert and close a valve of this character. The condition which probably ensues when a well discharges considerable quantities of solid matter is the development of a large cavity at the lower end of the casing, and eventually the shale roof of this cavity may cave in and seal off the water-bearing bed. In wells that are not constructed with perforated pipe having its lower end securely anchored in some firm bed lying beneath the water-bearing material, as here recommended, it will be found safer never to let the well have its full flow when it shows any disposition to throw sand or other matter. On the other hand, it is desirable not to shut a well off entirely, because more or less sand is apt to be forced up into the casing and become so set that further flow is completely shut off. 



\section{INDEX.}

A.

Aberdeen, wells at. . . . . . . . . . . . . . . . .

wells at, record of.

rocks in.

$39,40,41,50,55$

Albert well, record of. . . . . . . . . . . . . . . . . 112

Alexandria, rocks near. . .................. 34-35

Algonkian rocks, character and distribution of. .

$33-40$

Andover, wells at. .

90,91 wells at, record of

91

rocks in . . . . . . . . . . . . . . . 50,56

Arehean rocks, character and distribution of. 33-40

Ardmore, well at ....................... 100

Argentine, well at .................. 94, 100-101

well at, water of, analysis of .......... 101

Argyle, rocks at ...................... 24,25

Arikaree formation, character and distribution of.................. 27,31,32

Arlington, well at.................... 116 'well at, record of . ................... 116 rocks in....................... 38

Artesian, well near, record of . . . . . . . . . . 135-136 well near, rocks in................... 44

Artesian flows, explanation of ............. $\quad 7$ See also Flows; Wells.

$\Lambda$ smuss well, record of.................. 68

Aurora County, geology of................ 65

wells in. . . . . . . $66-67$

records of . . . . . . . . . . . . . . . . 67,68

rocks of . . ................. 44-45,51,55

B.

Bad River, rocks near.

Bartow well, record of . ................. 45

Battle Creek, rocks near ................... 14,21

Beadle County, geology of ................ 68-69

wells in . . . . . . . . . . . . . . . . . . . 69

rocks in . . . . . . . . . . . . . . . . . . 43,55

Bear Butte Canyon, rocks in, view of ....... 14

Beaver Creek, rocks in ................... 14

Bed rock. See Sioux quartzite.

Belle Fourche, rocks near. . . . . . . . . . . . . 20-22

wells near, records of $\ldots \ldots \ldots \ldots \ldots \ldots \ldots .78-81$

Belle Fourche River, rocks in ............ 24

Benton group, character and distribution of. 9 .

$20-22,27,48-53$

section of........................ 51

waters of ............................ 62

Big Badlands, rocks of . .................. $\quad 27$

view in.......................... 26, 28

Bighorn Mountains, section of, plate showing ...........................

Big Sioux River, rocks on and near..

49,53

Bigstone Lake, rocks at. . . . . . . . . . . . . . . . 52

Bijou Hills, rocks of .................... 58

Black Earth Creek, rocks near.............. 34
Page.

Black Hills, description of............... $8-9$ section of ......................... 9

figures showing. $\ldots \ldots \ldots \ldots \ldots \ldots \ldots, 8,59$

water horizons in, figure showing....... 59

See also Waters, underground.

Black Hills region, geology of............. $\quad 8-26$

geology of, general relations........... $8-10$

Bohri well, rocks in . . . . . . . . . . . . . . . . 39 section of ........................ 43

Bonhomme County, geology of ........... 69 wells in .......................... $70-72$

records of. . . . . . . . . . . . . . . . $71-72$

rocks in ..................... 47,51,54

Bowdle Hills, rocks on. ................. 58

Bridgewater, rocks near............... 34

Brookings, well at.................... 72

well at, rocks in ................... 38

Brookings County, geology of.............. 72 wells of ........................... 72

Brooks well, record of . . . . . . . . . . . . . . 115

Brown County, geology of ............... $\quad 72$ rocks in........................... 57 wells in .......................... 73

Brown Valley, well in, rocks of ........... 39

Brule clay, character and distribution of. 9,24-25,27 views of .......................... 26,28

Brule County, geology of ................ 74 wells in . . . . . . . . . . . . . . . . . . . $74-75$ records of ...................... 75 rocks in........................ 47

Brule Creek, rocks on. ................... 54

Budlong well, rocks in................... 38 section of ........................ 42

Buffalo County, geology of .............. 75-76 wells in . . . . . . . . . . . . record of ...................... 76 rocks in ........................ 51

Buffalo Gap, rocks near......... 15,16,17,18,19 section near....................... 22 wells at . . . . . . . . . . . . . . . . . . . . . $88-89$

Butte County, geology of............... 76-77 wells in .............................. $77-81$ records of....................... $78-81$

\section{C.}

Cambria, coal near. .................... 18

Cambrian rocks, character and distribution of 10-11

Campbell County, geology of ............. 81 wells in.............................. 81

Capa, well at.......................... 120-121 well at, rocks in...................... water of, analysis of .............. 121

Carboniferous rocks, character and distribution of . . . . . . . . . . . . . . . 10,11-15

Carlile shale, character and distribution of. 9,21-22 sections of ...................... 
Page.

Carthage, wells at, rocks in

51

Cascade springs, rocks near......... 15,16,18,19

Castalia, well near, rocks in............. 47,55

Castle Rock, rocks of.................. 31,32

Cave Hills, lignite at, view of.............. 30

rocks of ........................... 31

section near. . . ....................... 28-29

Cedar Draw, view in................... $\quad 26$

Chadron formation, character and distribution of................... 9,24-25,27

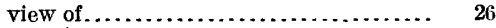

waters of ........................... 63-64

Chamberlain, wells at............... 119-120

wells at, record of................... 75

rocks in ...................... 47

Chambers Ranch, well on, record of........ 81

Charles Mix County, geology of............ 82

wells in ........................... 82-84

records of. ................... $5,83-84$

rocks in ....................... 47,55

Cheyenne Agency, well at. ............. 84-85

well at, record of.................... 85

Cheyenne Indian Reservation, geology of.... 84

wells of ......................... 84-85 records of.................. 85

Cheyenne River, rocks on....... 18-19,21,24,26,27 sections of, on and near. . . . . . . . . . 19,22

Clark, wells at.......................... 86

Clark County, geology of ................. $\quad 85$ wells in . . . . . . . . . . . . . . record of $\ldots \ldots \ldots \ldots \ldots \ldots \ldots \ldots, \quad 86$ rocks in ........................ 43

Clay County, geology of . . . . . . . . . . . . . 86-87 wells in .......................... 87

Clay Creek, rocks on................... $\quad 54$

Coal measures, section of. . . . . . . . . . . . . . $\quad 30$

Codington Co., geology of................. 87

Cold Brook, rocks on ................... 14

Columnar sections, figures showing........ 8,59

Cottonwood Draw, rocks on .............. 28 view at........................... 28

Cretaceous rocks, character and distribution of................ 10,17-24,41-58

Cross sections of South Dakota, plateshowing 24

Crow Creek, well at, roeks in............. 51

Crow Creek Agency, well at.............. $\quad 76$ well at, record of ................... 76

Custer, rocks near ..................... 12

Custer County, geology of. . . . . . . . . . . . . . $87-88$ wells of.

\section{D.}

Dakota sandstone, character and distribution of................... $9,20,40,41-48$ sections of......................... 42-48 structure map of. . explanation of

waters of ......................... 61-62

Davison County, geology of. . . . . . . . . . . . . 89-90 wells in . . . . . . . . . . . . . . . . . . . . $89-90$ rocks in ................ 44,50,54,55,56

Dawson Creek, rocks near............... 54

Day County, geology of................. $\quad 90$ rocks in .............................. 57 wells of ........................... 90-91 record of.
Deadwood rocks near rocks near, plate showing................ 10 Deadwood sandstone, character and distribution of...................... 10-11

view of $. . \ldots \ldots \ldots \ldots \ldots \ldots \ldots \ldots \ldots, 10$

waters of............................ 63

Deers Ears, rocks of................... 30,31

De Smet, well at.................... 43, 116 well at, record of...................44,116 rocks in....................... 37-38

Deuel County, geology of ................ $\quad 92$

Dikes occurrence of ..................... 34

Dougan well, record of................. $\quad 45$

Douglas County, geology of............... 92 wells of........................... 92-93 rocks in ..................... $37,51,55$

Drainage, outline of.................... 8

Draper, well at............................ 121

Dry Creek, rocks on.................... $\quad 20$

Durst well, record of.................... $\quad 79$

E.

Edgemont, rocks near......... 18,20,21, 24,25-26 rocks near, view of.................... 20

wells near...................... 94,95-99 record of...................... 95-98 water of, analysis of . . . . . . . . . . . 99

Edmunds County, geology of............ 93 wells of............................ 93

Elevations, range of. $\ldots \ldots \ldots \ldots \ldots \ldots \ldots \ldots . .6$ Elk Creek, rocks on................... 12

Elk Mountain, rocks near................ 15

Enemy Creek, rocks on............. 35, 49-50,54 Englewood limestone, character and distribution of....................... 10,12 Ethan, wells at and near, rocks in . . . . . 44, 50-51

\section{F.}

Fairburn, rocks near.............. 10,15,24, 25

Fall River, rocks on.................. 18, 19

Fall River County, geology of............. 94 section across, figure showing........... 94 wells in ........................... 94-101 records of................... 95-98, 100

Faulk County, geology of................ 101 wells in.......................... 101-102 record of....................... 102 rocks in . . . .

Faulkton Hills, rocks on................ 58

Fiestner well, record of .................. 113

Firesteel Creek, rocks on............... 49,50,54

Flint Creek, rocks on................... 28

Flows, area of . ....................... 64-65 area of, map showing ................. Pocket. volume of, plate showing............. 64

Forest City, rocks near.................. 58

Fort Meade, rocks near................. $\quad 16$ well at............................ 125-126

record of....................... 125-126

Fort Randall, well at, record of........... 104

Fort Union formation, character and distribu-

tion of..................... 26-31

Fossils, occurrence of................... 18, $20,21,22,23,28,31,48,49,52-53,58$ Fox Hill sandstone, character and distribution $\ldots \ldots \ldots \ldots \ldots .9,24,27,28-31,58$

waters of. 
Page.

Frankfort, well at, section of.............. 42

French Creek, rocks on................. 14, 21

Fulton, rocks near...................... 35

Fuson Creek, rocks on ................. 19-20,25

Fuson formation, character and distribution

of..................... 9,19-20,41

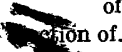

19

G.

Garden, rocks near.

Geography, description of.

Gettyoburg, well at, rocks in

G.

Whetion of.

Grand River, rocks on

Graneros shale, character and distribution

$$
\text { of........................ 9,20-21 }
$$

view of............................. 20

Grant County, geology of ............... 102

wells in ......................... 102-103

rocks in . . . . . . . . . . . .

Great Plains, description of.

Greenhorn limestone, character and distribu-

tion of..................... 9,21

view of . ........................... 20

Greenwood, well at, record of............. 83-84

Gregory County, geology of............... 103

wells of........................... 103-104

record of....................... 104

Groton, rocks near.................... 57

Gypsum, character and distribution of..... 15-16

H.

Hamlin County a geology of

wells of............................ 104-105 record of........................ 105

Hanson County, geology of............... 106

map of............................ 106

underground ridge in ................. 34

wells in.......................... 106-107

record of....................... 107

rocks in........................ 50

Harrold, well at, record of ................. 109

Hartville uplift, section of, plate showing... 8

Hay Creek, rocks near ................... 18, 20

Hayden, F. V., on geology of region........ 27

Haystack Butte, rocks of . ...............

Hermosa, rocks near...... 14,15, 16, 17, 18, 20, 23, 24 rocks near, view of . . . . ............. 14

Hetland, well at, record of............... 117

Highmore, well at...................... 141 well at, record of . . . . . . . . . . . . . . . 111

Hitchcock, wells near, rocks in . . .......... 38, 50

Hot Springs, rocks near . . . . . . 13,14,16,17, 18,19 section near......................... 19 well at............................ 101

Hughes County, geology of............... 108 wells at.......................... 108-109 record of . . . . . . . . . . . . . . . . . . 108, 100 rocks in......................... 48

Hurley, wells at and near................ 148 rocks in ....................... $46,51,54$

Huron, well at, record of . . . . . . . . . . . . .

Hutchinson County, geology of............. 109

wells in ......................... 109-111

record of ....................... 110-111

rocks in ................. 45-46,51,54
Hyde County, geologr of wells of record of ........................ 111

Hydraulic grade, explanation of . ......... 60-61 figures showing........................ 60,61

Hydrology, meaning of term............. 7

I.

Ipswich, wells at....................... 93

Iroquois, well at..................... 114-115 well at, record of .................... 114 rocks in .......................... 38

J.

James River, rocks near...... 35, 49, 50, 53-54,56-57 section of, showing hydraulic gradient... 61

Jerauld County, geology of . . . . .......... 112 wells in ............................ 112-113 records of..................... 112-113

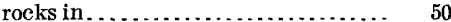

Johnson Creek, rocks near................. 35 Jurassic rocks, character and distribution of.. 10. $16-17,41$

K.

Kennebec, wells at...................... $\quad 121$

Kimball, well at, rocks in................ $\quad 47$

Kingsbury County, geology of. ............ 113 wells in .......................... 113-117 records of...................... 114-117 rocks in .......................... 55

Knams ,ell, record of. . ................. 107

Kot $1 \mathrm{k}$, rocks of.................. 58

\section{L.}

Lake A tes, wells at, records of.......... 51,83

Lake Cout ty, geology of . . . . . . . . . . . . . 117 wells $1 . . . \ldots \ldots \ldots \ldots \ldots \ldots \ldots \ldots . . .118$

Lakota saindstone, character and distribution ipf......................... 9,18,41 view of $\{\ldots \ldots \ldots \ldots \ldots \ldots \ldots \ldots \ldots, 10$

Lame Johnny Creek, rocks on............. 24,25 Laramie formation, occurrence of. ........ 27,28-31

Laramie Range, section of, plate showing.... 8

Lawrence County, geology of. ............ 118. wells of............................ 118

Lead, rocks near. ......................... 26

Leonard, A. G., on geology of region.......... $30-31$

Letcher, rocks near..................... 53 well near.............................. 135 record of...................... 135 rocks in $. . \ldots \ldots \ldots \ldots \ldots \ldots \ldots \ldots \ldots \ldots, 44,55$

Lignite, occurrence of.................... 18

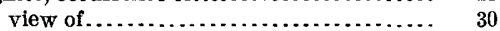

Lincoln County, geology of .............. 118-119

Lyman Gounty, geology .................... 119 wells of..... record of ............................ 120 water of, analysis of.............. 120

M.

MeClure well.......................... 120

record of . . . . .

MeCook County, geology of ............... 122

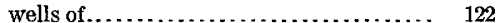

McPherson County, geology of............. 122 wells of ............................. 122-123

Madison, wells at......................... 118 wells at, rocks in .................. 37,118 
Page.

Map, artesian, of South Dakota showing volume of flows. .

Map, bed-rock contour, of South Dakota.... $\quad 32$

Map, geologic, of South Dakota ........... Pocket.

Map, structural, of Dakota sandstone....... $\quad 66$

Marshall, Minn., wells near, rocks in........ $\quad 52$

Marshall County, geology of .............. 123 wells of ........................... 123

Matthew, W. D., on Rosebud formation..... 27

Meade County, geology of................. 124 wells of.......................... 124-126

records of.................... 125-126

Metamynodon sandstone, character and histribution of................... 27

Milbank, rocks at........................ 49 wells at, rocks in . . . . . . . . . . . . . . 39,52

Miner County, geology of............... 126 wells of ....................... 126-127

rocks in . . . . . . . . . . . . . . . . 51,55

Minnehaha County, geology of............ 127 wells of ........................... 127

Minnekahta, rocks near................. 24,25 well at........................... 99-100 record of ...................... 100

Minnekahta Junction, well at.............. 38 Minnekahta limestone, character and distribution of. ................ 10,14-15

view of ............................ 14

Minnelusa sandstone, character and distribution of .................... 10,13-14

view of............................ 14

waters of $\ldots . \ldots \ldots \ldots \ldots \ldots \ldots \ldots \ldots .62-63$

Minnewaste limestone, character and distribution of . ................ 9, 18-19

Mississippian rocks, character and distribution of.................. 10,13,14

Missouri River, rocks on .............. 26,49,56

Mitchell, rocks near.................... 33,37

wells at and near.................... 89

rocks in . . . . . . . . . . . . . . . .

view of $\ldots \ldots \ldots \ldots \ldots \ldots \ldots \ldots \ldots, 134$

Montrose, rocks near................... 34

Moody County, geology of ................ 127

- wells of .......................... 127-128 record of ....................... 128

Morrison shale, character and distribution of. $\quad 9$,

Mount Vernon, well at . . . . . . . ............ $\quad 89$ well, record of ..................... 44

Mowry shale, character and distribution of. . 21

Murdo MeKenzie, well at................ 121

\section{$\mathrm{N}$.}

Newcastle, rocks near....................

Niobrara formation, character and distribution of ............... 9,22,26, 53-56

Niobrara River, rocks on ................. 53

Nowlin, well at....................... 139-140 weh at, rocks in .................... 26 water of, analysis of ............. 140

o.

Oelrichs, rocks near ................... 23,24

Oneida, well at, record of............... 141 opeche formation, character and distributicnct..................... 10,14
Ordovician rocks, character and distribution of...................... 10,11

Oreodon beds. See Brule clay.

Orient, well near, record of ............... 102

Orman welt, rocks in .................. \$ 80 water of, analysis of . . . . . . . . . . . . . 80

Ortonville, rocks near................. $\quad 39$

Owl River, rocks on.................. 24,28

\section{P.}

Pahaspa limestone, character and distribution of ................... 10,12-13

Parker, rocks near.................... 34

Parkston, wells at, rocks in ............ 45-46

Pennington County, geology of ............ 128

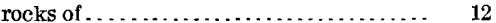

wells of......................... 128

Pennsylvanian rocks, characterand distribution of ..................... 10,14

Permian rocks, character and distribution of. 10 ,

14,15

Pierpoint, well at. ..................... 90,91

Pierre, wells at, record of ................ 48

wells at, rocks in . . . . . . . . . . . . . . 40

Pierre Creek, rocks on .................... 34,35

Pierre shale, character and distribution of ... 9 , $22-24,26,27,28,56-58$

Pine Ridge Reservation, geology of........ 128-130 wells of. . . . . . . . . . . . . . . . . . . . . 129-130

Pipestone, rocks near...... $\ldots \ldots \ldots \ldots \ldots \ldots .33,34$ Pipestone clay, character and distribution of. $\quad 34$

Plankinton, rocks near.................. 53 wells at and near.................. 44,68 record of........................ 68

rocks in . . . . . . . . . . . . . . . . . . $44-45$

Ponca, Nebr., well at, rocks in........... 39, 40

Post-Eocene rocks, character and distribution of...................... $31-32$

Potter County, geology of............... 130

wells in ........................... 130

record of $\ldots \ldots \ldots \ldots \ldots \ldots \ldots \ldots, 130$

rocks in....................... 48

Pringle, rocks near. . . . . . . . . . . . . . . ..... 24

Protoceras sandstone, character and distribution of...................... 27

view of ............................ 28

Pukwana, well at, record of .............. 75

Purple limestone. See Minnekahta limestone.

Q.

Quaternary deposits, character and distribution of..................... 58

R.

Raesley well, record of.................. 67

Rapid, rocks near . . . . . . . . . . . . . $12,17,20$

wells near......................... 128

Rapid Creek, rocks on .................. 10,24

Raymond, wells at and near.............. 85 well at and near, records of ............ 43, 85

Reagan, A. B., on Rosebud Reservation.... $\quad 27$

Ree Heights, rocks at................... $\quad 57$

Resley well, record of ........................ 45

Roberts County, geology.................. 131

wells of ............................... 131

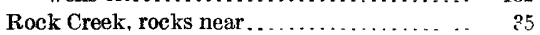


Page.

Rockerville, rocks near.

Rockport, rocks near

Rosebud, well at, rocks

Rosebud member, occurrence of .............

Rosebud Reservation, geology of............ 131 well on........................... 131-133 rocks in ........................ 48 record of....................... 132

Ryan well, record of.

S.

Salem, rocks near 34

Sanborn County, geology of............... 133 wells in.......................... 133-136

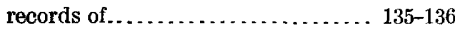
rocks in . ........................ 44,55

Schmidt well, record of ................. 113

Scotland, well at..................... $70-74$ well at, record of .............. 47,51,71-72 rocks in ........................ 54

Selby, well at.......................... 143

Sheep Mountain, view of................ 28

Shelby, well at....................... 93

Sheps Canyon, rocks near................. 16,17 view in............................. 10

Short Pine Hills, rocks of.............. 30,31

Sioux City, Iowa, rocks at................ 49 wells at, rocks in . . . . . . . . . . . . . . 39-40

Sioux Falls, well at, rocks in ............... 34, 37

Sioux quartzite, character and distribution of . 33-34 surface of, map showing................ wells to ............................ $35-36$

Slim Buttes, rocks of............... 26, 30,31 sections at......................... 31, 32

South Dakota, map of, showing hydraulic contours......................

South Dakota, eastern, geology of . ......... 32-58 section of, figure showing.............. 59 structure of ....................... $32-33$ water horizons in, figure showing....... 59 See also Waters, underground.

South Dakota, northwestern, explorations in. 27 geology of. ......................... 27-32

South Dakota, south-central, geology of..... 26-27

Spear well, record of..................... . 115

Spearfish, rocks near.................... $\quad 16$ wells near ........................... 118

Spearish Creek, rocks on ................. 12-13

Spearfish formation, character and distribution of..................... 9, 15-16

Spencer, rocks near..................... 34

Spink County, geology of . ............... 136

wells of......................... 136-137 rocks in ................. 42,50,55, 137

Split Rock Creek, rocks on ............... 34,54

Spring Creek, rocks near.............. 13,14,21,25

Springfield, well near..................... 70 well near, rocks in................. 47,51,54

Squaw Creek, rocks on ...................

Standing Rock Reservation, geology of..... 138 wells of............................. 138

Stanley County, geology of.............. 138-139 wells of.......................... 139-140 water of, analyses of .............. 139,140

Storla well, record of.

Streams, seepage from
Page. view of . . . . .

wells near ......................... 124-125 record of........................... 125

Sully County, geology of................. 140

wells of........................... 140-142

records of $\ldots \ldots \ldots \ldots \ldots \ldots \ldots \ldots 141-142$

Sundance formation, character and distribu-

tion of ..................... 9,16-17

Susie Peak, rocks of .................... 21

Swan Creek, rocks on .................... 58

Swan Lake, rocks at ..................... 57

\section{$\mathrm{T}$.}

Tepee buttes, distribution and character of... 23 Tertiary rocks, character and distribution of. . 9, $24-27,58$

section of . ........................ $\quad{ }^{-32}$

The Dells, rocks near................... 34

Titanotherium beds. See Chadron formation.

Todd, J. E., on geology of region..... 28, 48, 52,58

Thunder Creek, rocks on................. 28

Topography, description of............... 8

Trent, well at, rocks in ................... 58

Triassic rocks, character and distribution of 9,15-16

Tripp, well at, record of. . ............. 110-111 well at, rocks in . ............... 46,51,54-55

Turkey Ridge, rocks of . . ............... 53,54

Turner County, geology of............... 142 wells in ........................... 142

rocks of . . . . . . . . .

Turtle Ridge, rocks of ................. $\quad 57$

Twelvemile Creek, rocks on ..........49-50,54

U.

Underground ridge, location and character of. $\quad 33$,

$37-40$

Union County, geology of............... 142

wells of $\ldots \ldots \ldots \ldots \ldots \ldots \ldots \ldots \ldots, 143$

record of ....................... 143

Uǹkpapa sandstone, character and distribution of . ..................... 9,17

view of .......................... 10

V.

Vermillion River, rocks̄ on............... $\quad 34$

Vivian, well at. ........................ 121

Volcanic ash, occurrence of . ............... 26

\section{W.}

Walworth County, geology of............. 143

wells of ............................ 143

Wasta, well near...................... 128

Waters, underground, discussion of....... 59-149 discussion of, by counties............. $65-149$ escape of ........................... 148-149

figures showing.................. 148 horizons of, descriptions of. . . . . . . . . 61-64

figures showing. ................. 59 source and movement of.............. 7,60

Webster, well at........................ 91

Well boring, methods of................ 147-148

Wells, description of, by counties......... 65-149 general discussion of . . . . . . . . . . . . . . . $64-65$ 


\section{INंDEX.}

Wells, artesian, construction and management....................... 146-149 distribution, of, map showing. Pocket. pressures in.........

. area of, map showing............... Pocket. necessary depth of................... 65 volume of, map showing................ 64

Wells to quartzite, list of................ 35-36

Wendte, well at........................ 139

well at, water of, analysis of.......... 139

White Lake, well at, rocks in............. 45

White River, rocks near............... 24-26, 27

White River group, character and distribution of. . ........ 9,24-26,27,29,31, 32 section of

views of $\ldots \ldots \ldots \ldots \ldots \ldots \ldots \ldots \ldots \ldots .28,30$

Whiterock, well at, rocks in ............. $\quad 52$

Whitewood Canyon, rocks in ............. 11

Whitewood limestone, character and distri-

$$
\text { bution of. }
$$

Wildeat Gulch, view of
Willis, Bailey, on geology of region.

Willow Creek, rocks on .

Winchell, $\mathrm{N} . \mathrm{H}$, , on geology of region.......27, 84

Wolf Creek, rocks near................ 34,54

Wolsey, well at, record of................. well at, rocks in ..................... 38

Woonsocket, well at.................. 134-135 well at, record of . . . . . . . . . . . . . . . 134-135 rocks in ....................... 44,55 view of........................ 134

Wounded Knee Creek, rocks on, view of..... 30

\section{$\mathrm{Y}$.}

Yankton, rocks near.................. 53,57 wells at......................... 145-146 wells at, records of. . . . . . . . . . . . 46, 145-146 rocks in ................

Yankton Agency, well at, record of. . . . . .... 83-84

Yankton County, geology of............. 143-144

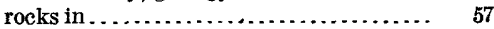
wells in . . . . . . . . . . . . . record of . . . . . . . . . . . . rocks in.......................... 